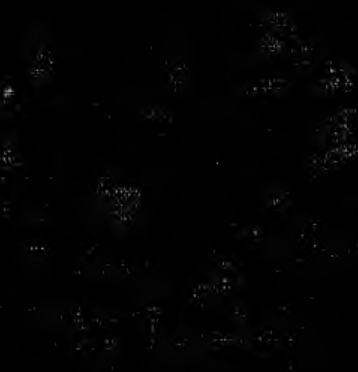

$=\frac{1}{2}+\frac{1}{2}$

,

the

sis: 


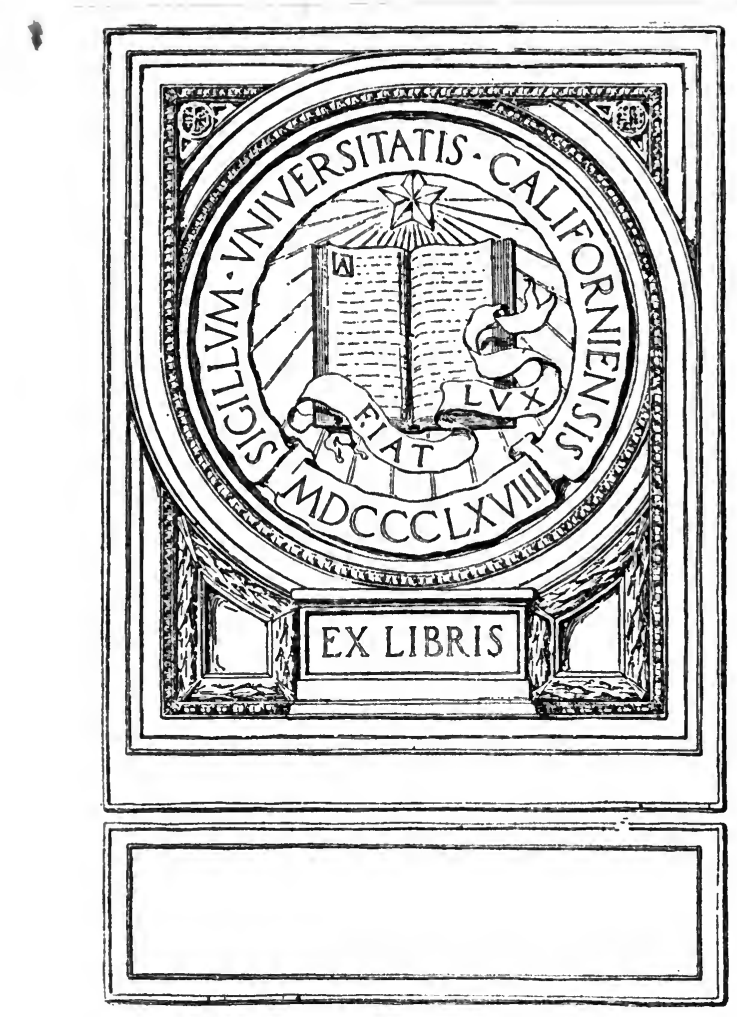



Digitized by the Internet Archive in 2007 with funding from Microsoft Corporation 


\section{THE QUESTION}

OF THE

BOSPHORUS AND DARDANELLES. 



\section{THE QUESTION}

OF THE

\section{B0SPH0RUS AND DARDANELLES.}

BY

COLEMAN PHILLIPSON, M.A., LL.D., LitT.D.,

OF THE INNER TEMPLE, BARRISTER-AT-LAW,

AUTHOR OF

'THE INTERNATIONAL LAW AND CUSTOM OF ANCIENT GREECE AND ROME';

'INTERNATIONAT LAW AND THE GREAT WAR'; 'TERMINATION OF WAR AND TREATIES OF PEAOE'; FTC.,

AND

NOEL BUXTON, M.A., M.P.,

$\triangle$ UTHOR OF

'EUROPE AND THE TURKS'; 'THE WAR AND THE BalKaNs';

'TRATEL AND POLITICs IN aRMCENIA'; etTo.

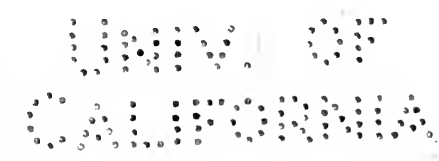

LONDON :

STEVENS AND HAYNES,

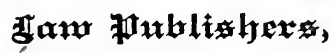

BELL YARD, TEMPLE BAR. 
\begin{tabular}{c}
2571 \\
\hline 5 \\
0.041
\end{tabular}

$\because 4 \quad \because \vdots \vdots \vdots$

औ औ 


\section{$(\mathrm{v})$}

\section{PREFACE.}

ONE of the most important questions of modern European politics is that of the Straits of the Bosphorus and the Dardanelles: it constitutes the very essence of the Near Eastern Question-that knot which for many long years men and nations have endeavoured to untie by all the arts of diplomacy, all the devices of political combinations, and all the violence of wars. Another effort will be made to solve this baffling problem at the conclusion of the present war; and the negotiators who attack it in a spirit of fairness and equity, with a due regard to the interests of all, and succeed in reaching a generally acceptable solution, will surely earn the blessings of mankind. Perhaps no other question in the recorded history of the world has given rise to so much tortuous diplomacy, to so much international jealousy and friction, to so much sinister rivalry, to so many bitter wars, as this fateful question has produced. To remove the cause of this perennial misunderstanding and conflict is to confer an inestimable boon, not only on the European group of States, but also on the whole family 
of nations-for the peoples of the world are indissolubly bound together, whether they like it or not.

The present work-the first of its kind in Englishattempts to set forth as briefly and as clearly as possible the rise, development, and vicissitudes of this problem of the Straits; to analyse it into its constituent elements; to show the efforts that have been made in the past to solve it; to expound and critically examine from the point of view of international law the régimes that have been established by conventions; and, finally, to suggest what appears to be in the present state of affairs the most desirable solution.

C. P.

N. B. 


\section{( vii )}

\section{CONTEN'TS.}

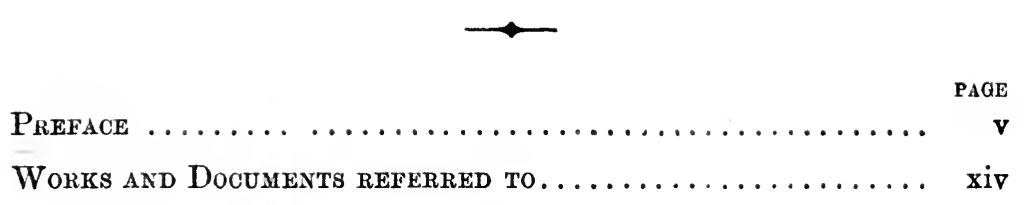

PART I.

The Problem of the Bosphorus and the Dardanelles.-The Position of Waterways in General under International Law.

\section{CHAPTER I.}

The Problem of the Bosphorus and the Dardaneliles $\ldots . .1-9$

The Straits problem and the present War .......... 1

Position of Turkey in regard to Europe ........... 2

Essence of the Straits problem $\ldots \ldots \ldots \ldots \ldots \ldots \ldots \ldots$

Position of Russia ...................... 4

Policy of Russia $\ldots \ldots \ldots \ldots \ldots \ldots \ldots \ldots \ldots \ldots \ldots$

The Straits question must be solved ............ 8

\section{CHAPTER II.}

Thr Position of Waterways in General under In'ternational

LAW .......................10-16

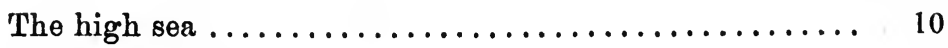

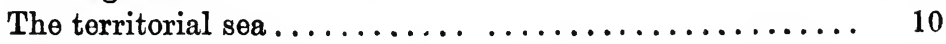

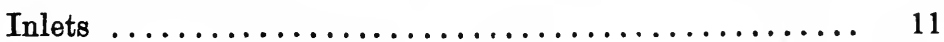

Lakes and land-locked seas ................... 11

Straits ................................ 13

Interoceanic canals $\ldots \ldots \ldots \ldots \ldots \ldots \ldots \ldots \ldots \ldots \ldots$ 


\section{PART II.}

The Evolution of the Rule of the Straits of the Bosphorus and the Dardanelles.

\section{CHAPTER I.}

From the Beginning of the Capitulations to the end of the Eighteenth Century $\ldots \ldots \ldots \ldots \ldots \ldots \ldots \ldots$. . . 31

The Black Sea as a Turkish lake .............. 17

The system of capitulations ................. 18

Position and policy of Russia ................. 21

Conflicts with Turkey-Peter the Great-Catherine II. . . . 22

Treaty of Kutchuk-Kainardji, $1774 \ldots \ldots \ldots \ldots \ldots \ldots 27$

Peace of Jassy, $1792 \ldots \ldots \ldots \ldots \ldots \ldots \ldots \ldots \ldots \ldots \ldots$

\section{CHAPTER II.}

From the Treaty of Constantinople, 1798, to the Treaty of

Bucharest, $1812 \ldots \ldots \ldots \ldots \ldots \ldots \ldots \ldots \ldots \ldots$

Treaties of Campo-Formio, 1797, and Constantinople, 1798.. 32

Scheme to partition Turkey ................. 33

Kotchoubey's report, $1802 \ldots \ldots \ldots \ldots \ldots \ldots \ldots \ldots \ldots \ldots$

Peace between France and Turkey, $1802 \ldots \ldots \ldots \ldots \ldots . \ldots . \ldots$

Projected Russo-Turkish union ............... 35

Treaty of Constantinople, $1805 \ldots \ldots \ldots \ldots \ldots \ldots \ldots \ldots \ldots$

Treaty of Pressburg, $1805 \ldots \ldots \ldots \ldots \ldots \ldots \ldots \ldots \ldots \ldots$

Passage of Russian warships through the Straits, 1806 . . . 37

Treaty of 1805 denounced by Turkey. . . . . . . . . . . . 39

Peace of Tilsit, $1807 \ldots \ldots \ldots \ldots \ldots \ldots \ldots \ldots \ldots \ldots \ldots . \ldots \ldots$

Franco-Russian plan to partition Turkey, $1807 \ldots \ldots \ldots \ldots .41$

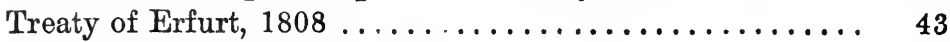

Peace of the Dardanelles, $1809 \ldots \ldots \ldots \ldots \ldots \ldots \ldots \ldots . \ldots 43$

Treaty of Bucharest, $1812 \ldots \ldots \ldots \ldots \ldots \ldots \ldots \ldots \ldots \ldots$ 
CHAPTER III.

Treaties of Adrianople, 1829, and Unkiar-Skelegsi, $1833 \ldots 47-69$

Greek revolt, $1821 \ldots \ldots \ldots \ldots \ldots \ldots \ldots \ldots \ldots \ldots \ldots$

Treaty of Akkerman, $1826 \ldots \ldots \ldots \ldots \ldots \ldots \ldots \ldots . \ldots 49$

Treaty of London, $1827 \ldots \ldots \ldots \ldots \ldots \ldots \ldots \ldots \ldots$

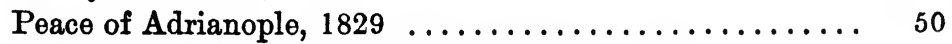

Treaty between United States and Turkey, $1830 \ldots \ldots \ldots \ldots 54$

Revolt of Mehemet Ali, $1831 \ldots \ldots \ldots \ldots \ldots \ldots \ldots \ldots$

The Tsar's attitude towards Turkey .............. 57

Efforts of France to secure passage for warships........ 59

Secret Russo-Turkish negotiations, $1833 \ldots \ldots \ldots \ldots \ldots \ldots 60$

Treaty of Unkiar-Skelessi, $1833 \ldots \ldots \ldots \ldots \ldots \ldots \ldots \ldots . \ldots \ldots$

Protests against it .................... 67

\section{CHAPTER IV.}

The Convention of London, 1840, and the Straits Conven-

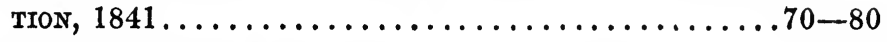

Rivalry between England and Russia in the East . . . . . . 70

Convention of Münchengrätz, $1833 \ldots \ldots \ldots \ldots \ldots \ldots \ldots \ldots-71$

Difficulties of the Russo-Turkish alliance .......... 71

War with Mehemet Ali, $1839 \ldots \ldots \ldots \ldots \ldots \ldots \ldots \ldots \ldots$

Intervention of the Powers .................. 72

The Tsar's declarations as to Turkey and the Straits ..... 73

Treaty of London, $1840 \ldots \ldots \ldots \ldots \ldots \ldots \ldots \ldots \ldots \ldots \ldots$

The Straits Convention, $1841 \ldots \ldots \ldots \ldots \ldots \ldots \ldots \ldots$ 
CHAPTER $\nabla$.

The Trgaty of Paris, $1856 \ldots \ldots \ldots \ldots \ldots \ldots \ldots \ldots . \ldots . \ldots 1-100$

The Straits Convention and Russian policy ........... 81

Turkish safeguards with regard to the Straits ......... 81

Nicholas' view of Turkey as a 'sick man' ........... 82

The question of the Holy Places................. 83

Partition scheme of Nicholas ................... 83

Mission of Menshikoff, 1853 ................... 84

Occupation of the Danubian Principalities-The Straits

Convention in question..................... 85

Allied fleets in the Black Sea ................. 86

The Straits Convention and the Crimean War ......... 87

Questions before the Conference, $1855 \ldots \ldots \ldots \ldots \ldots \ldots .91$

Treaty of Paris, 1856 ...................... 94

Convention between Russia and Turkey ........... 97

Convention between Great Britain, France, and Austria .. 98

The Treaties of Paris as collective engagements ........ 98

Position of Russia after the treaty................. 99

\section{CHAPTER VI.}

Denunciation of the Treaty of Paris-Treaty of London,

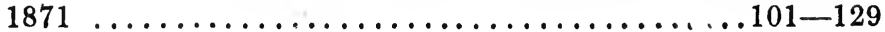

Difficulties of Russia........................... 101

Determination of Alexander ..................... 102

Attitude of King William of Prussia............... 103

Franco-Prussian War ........................ 103

Prince Gortchakoff's circular .................... 105

Special despatches sent to the signatory Powers ........ 107

Protest of Great Britain ......................... 109

Attitude of the other Powers .................... 111

Examination of Gortchakoff's claims ................ 112

Negotiations for a Conference..................... 119

The London Conference, $1871 \ldots \ldots \ldots \ldots \ldots \ldots \ldots . . .6121$

Treaty of London, 1871 .................... 127 


\section{CHAPTER VII.}

The Russo-Turish War-The Treaty of San Stefano-The Treaty of BerLin, 1878 ..............130-149

The Triple Alliance ....................... 130

Panslavism and panislamism ................ 130

Christian rising in Balkans, $1875 \ldots \ldots \ldots \ldots \ldots \ldots \ldots 131$

Meeting of the Emperors at Reichstadt, 1876. . . . . . . 132

The Tsar's assurances as to Turkey .............. 132

Proposal for a Conference .................. 135

Russian invasion of Turkey, $1877 \ldots \ldots \ldots \ldots \ldots \ldots \ldots \ldots$

Turkey's appeal to the Powers $\ldots \ldots \ldots \ldots \ldots \ldots \ldots \ldots \ldots 137$

Lord Derby's Note defining British interests ......... 138

Gortchakoff's undertaking . . . . . . . . . . . . . . . 139

Progress of the war $\ldots \ldots \ldots \ldots \ldots \ldots \ldots \ldots \ldots \ldots \ldots \ldots, 140$

Alarm in Europe $\ldots \ldots \ldots \ldots \ldots \ldots \ldots \ldots \ldots \ldots \ldots \ldots \ldots$

Couditions of peace-Russian demand as to the Straits . . . 142

Convention of Adrianople, January, $1878 \ldots \ldots \ldots \ldots \ldots \ldots 144$

British warships in Sea of Marmara ............. 145

Treaty of San Stefano, March, $1878 \ldots \ldots \ldots \ldots \ldots \ldots$

Congress of Berlin-Treaty of Berlin............. 148

\section{CHAPTER VIII.}

Interpretation and Application of the RUli of the Straits .

$150-177$

Difficulty in interpretation of the rule ........... 150

Instances of passage of warships $\ldots \ldots \ldots \ldots \ldots \ldots \ldots \ldots$

United States warship refused passage ............ 151

Other examples of refusal and of passage.......... 152

Collective nature of the rule ................... 153

Question of interpretation at Berlin Congress .......... 155

Lord Salisbury's explanation, $1885 \ldots \ldots \ldots \ldots \ldots \ldots \ldots$

New interpretation adopted by Russia, $1895 \ldots . \ldots \ldots \ldots . . . .62$

Recent instances of passage of warships ............ 163

Altored views of Great Britain and Russia ... . . . . . . . 169

The Straits Question in the Russo-Japanese War ...... 170

Incident of the Kniaz Potemkin, 1905 ............. 173

The Straits Question in more recent wars............ 173

What vessels are warships $\ldots \ldots \ldots \ldots \ldots \ldots \ldots \ldots \ldots . \ldots \ldots$

The existing rule unsatisfactory . . . . . . . . . . . 176 
PART III.

\section{Reoonstruction.}

\section{CHAPTER I.}

PAGE

The Attitude of Russia during the Nineteenth Century . 178-187

Varying Russian views.................... 178

The 'sick man' theory, $1800 \ldots \ldots \ldots \ldots \ldots \ldots \ldots \ldots . \ldots 178$

Policy of Alexander I. . . . . . . . . . ............... 178

Policy of Nicholas I. . . . . . . . . . . . . . . . . . . . 179

Brunnow's declaration, $1839 \ldots \ldots \ldots \ldots \ldots \ldots \ldots \ldots$

The 'sick man' theory again, $1853 \ldots \ldots \ldots \ldots \ldots \ldots$

Gortchakoff's proposal as to passage in the Straits . . . . . . 181

Russia's policy after the Crimean War ............. 181

Her efforts in $1877-78 \ldots \ldots \ldots \ldots \ldots \ldots \ldots \ldots \ldots$

The panslav movement.................... 183

\section{CHAPTER II.}

Recent Efforts of the Russian Government to modify the Rule of the Straits-Attitude of the PowersDevelopment of Opinion in Russia-Schemes for ReCONSTRUCTION SUGGESTED-INFLUENCE OF THE PRESENT

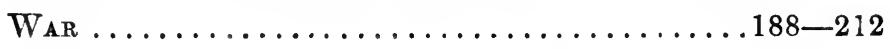

Recent efforts of Russia to procure passage for her war-

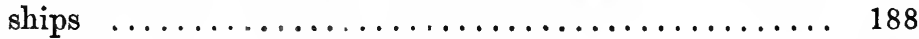

Various political combinations established ......... 188

The Austrian annexation, $1908 \ldots \ldots \ldots \ldots \ldots \ldots \ldots \ldots$

Plan for forming a Balkan League . . . . . . . . . . 190

Russia's step in the Turco-Italian War, $1911 \ldots . . \ldots \ldots . .190$

Attitude of Great Britain and France .............. 191

Austro-German opposition to Russia . . . . . . . . . . . 192

The Balkan League, $1912 \ldots \ldots \ldots \ldots \ldots \ldots \ldots \ldots$

The Balkan Wars ........................ 193

Recent opinion in Russia .................... 194

The War and Russian opinion $\ldots \ldots \ldots \ldots \ldots \ldots \ldots \ldots$ 


\section{CHAPTER III.}

PAGE

Opinion outside Russia-Various Sohemes suggested $\ldots .213-223$

In favour of Russian acquisition $\ldots \ldots \ldots \ldots \ldots \ldots \ldots 213$

Constantinople under Belgian rule............. 215

In favour of freedom for all vessels and internationalisation 215

Efforts of the United States to procure passage for warships $(1868-71) \ldots \ldots \ldots \ldots \ldots \ldots \ldots \ldots \ldots \ldots$

Recent views ....................... 218

Military guardianship of United States suggested ... 220

View of Sir Edwin Pears. ................ 222

\section{CHAPTER IV.}

Which is the Best Solution ? . . . . . . . . . . . 224-249

The old rule no longer tenable ............... 224

Why it has failed ........................ 225

The problem of the Straits now different .......... 227

Whether Russian possession of the Straits is advisable . . . 229

Other Powers directly concerned. .............. 231

International commerce in the Straits ........... 232

Protection of States on the Black Sea ............ 233

Opening to all as the fundamental principle......... 233

How liberty of navigation to be established.......... 236

Benefits of international co-operation ............ 237

Internationalisation and neutralisation ............. 239

Principles suggested for the Straits $\ldots \ldots \ldots \ldots \ldots \ldots \ldots .239$

International Commission $\ldots \ldots \ldots \ldots \ldots \ldots \ldots \ldots \ldots . \ldots \ldots$

The Danube Commission .................... 242

Other provisions regulating the Danube .......... 246

Future of Constantinople................. 247

Position of Turkey with regard to Europe .......... 248 


\section{WORKS AND DOCUMENTS REFERRED TO.}

[Besides those given below, several other works are cited which need not be included in this list.]

\section{(A) WORKS.}

Adair, Sir R. The negociations for the Peace of the Dardanelles in 1808-9. 2 vols. (London, 1845).

Alexinsiy, G. Russia and the Great War. English translation. (London, 1915.)

Asmlex, E. Life and correspondence of Henry John Temple, Viscount Palmerston. (London, 1879.)

Bluntschli, J. C. Das moderne Völkerrecht. (Nördlingen, 1872.)

Bulwer, Sir H. Lxtron. Life of Palmerston. (London, 1870.)

Butler, A. J. (Trans.). Bismarck the man and the statesman-being the reflections and reminiscences of Otto Prince von Bismarck. 2 vols. (London, 1898).

Charrière, E. Négociations de la France dans le Levant. 4 vols. (Paris, 1848-1860).

Dascovici, N. La question du Bosphore et des Dardanelles. (Genève, 1915.)

Debidour, A. Histoire diplomatique de l'Europe. (Paris, 1891, etc.)

Demorgny, G. La question du Danube. (Paris, 1915.)

Driault, E. La question d'Orient depuis ses origines jusqu'd nos jours. (Paris, 1905.)

DugGan, S. P. H. The Eastern Question. A study in diplomacy. (New York, 1902.) [Studies in history, economics, and public law; Columbia University: vol. xiv. No. 3.]

GrFFomen, F. H. Incidents de droit international dans le différend anglo-russe, in Revue de droit international. (Bruxelles, 1885.)

Goriainow, S. Le Bosphore et les Dardanelles. (Paris, 1910.)

Gurzor, F. P. H. Mémoires pour servir d. l'histoire de mon temps. (Paris, 1858.)

Hoschruler, M. L'Europe devant Constantinople. (Paris, 1916.) 
Kamarowski, Count L. Des causes politiques de guerre dans l'Europe moderne, in Revue de droit international. (Bruxelles, 1888.)

Laloy, E. Les plans de Cathérine II. pour la conquête de Constantinople. (Paris, 1913.)

Le Correspondant. (Paris, Sept. 1913.)

Lozé, M. La question des Détroits. (Paris, 1908.)

MARTENs, F. DE. Étudełistorique sur la politique russe dans la question d'Orient, in Revue de droit international et de législation comparée. (Bruxelles, 1877.)

Moore, J. B. Digest of international law. 8 vols. (Washington, 1906).

Pélissí dU RaUsas, $G$. Le régime des capitulations dans l'Empire Ottoman. 2 vols. (Paris, 1902-1905).

$\checkmark$ Phillipson, C. International Law and the Great War. (London, 1915.)

Pinon, R. La mer Noire et la question des Détroits, in Revue des deux mondes, Oct. 1905.

Ratros, D. Constantinople ville libre. (Paris, 1860.)

Skupiewski, J. J. La doctrine panslaviste. (Bucarest, 1890.)

SoREL, A. Histoire diplomatique de la guerre franco-allemande. (Paris, 1875.)

- La question d'Orient au XVIIIe. siècle. (Paris, 1889.)

TAtistchefF, S. Alexandre ler et Napoléon d'après leur correspondance inédite, 1801-1812. (Paris, 1891.)

Toynbee, A. J. Nationality and the War. (London, 1915.)

VANDAL, A. Napoléon et Alexandre 1er. (Paris, 1891.)

Une ambassade française en Orient sous Louis XV. (Paris, 1887.) 
(B) TREATIES, OFFICIAL PAPERS, AND OTHER DOCUMENTS.

British and Foreign State Papers.

Dumont, J. Corps universel diplomatique du droit des gens. 8 vols.

(La Haye, 1726-1731).

Supplément. 5 vols. (La Haye, 1739).

Foreign relations of the United States.

Hansard. Parliamentary Debates.

Hertslet, C. (and others). Collection of treaties. (London, 1827, etc.)

Hertslet, Sir E. Map of Europe by treaty. 4 vols. (London, 18751891).

Martens, F. DE. Recueil des traités et conventions conclus par la Russie. (St. Pétersbourg, 1898, etc.)

Martens, G. F. DE. Recueil des traités. Nouveau Recueil. (1761, etc.)

Noradounghian, G. Recueil d'actes internationaux de l'Empire Ottoman. 2 vols. (Paris, 1897).

Parliamentary Papers.

Recueil des instructions données aux ambassadeurs et ministres de France.

Testa, I. DE. Recueil des traités de la Porte Ottomane avec les puissances étrangères. (Paris, 1864, etc.)

Wence, F. A. G. Codex juris gentium. 3 vols. (Lipsiae, 1781-95). 


\section{THE QUESTION}

OF THE

\section{BOSPHORUS AND DARDANELLES.}

\section{PART I.}

The Problem of the Bosphorus and the Dardanelles. -The Position of Waterways in general under International Law.

\section{CHAPTER I.}

THE PROBLEM OF THE BOSPHORUS AND THE DARDANELLES.

Whatever matter in dispute between the nations is The Straits

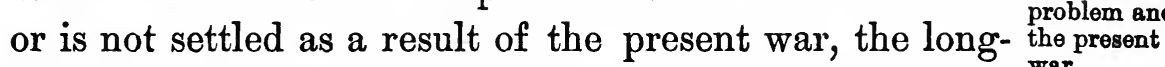
standing Near Eastern Question must be solved clearly and definitively. Various causes have been assigned to the origin of the existing convulsion of the world; but there is no doubt that this chronic malady of the Near East, which has lingered so long and has wrought such incalculable havoc in the past, has been the most potent factor in the chain of cause and effect that has brought the nations into armed conflict. And this complex and comprehensive question is itself made up of a number of closely allied problems, the most important of which is that of the Straits of the Bosphorus and the Dardanelles. The Powers have indeed made efforts again and again to solve these outstanding problems; but the results arrived at have never been other than temporary makeshifts, patched-up compromises, dictated usually by considerations of a selfish, suspicious policy and by subservience to unenlightened 'reasons of State' or 
'political expediency.' The price paid for this cherishing of mutual distrust and jealousy and for this international tinkering has been a series of wars, culminating in the Great War, which have cost so much blood and treasure, and which have sapped the very vitality of Europe.

Main factor in European politics.

The governing factor in European politics as a whole is the competition of the Great Powers for expansion in lands outside Europe. Europe being a peninsula with two bridges to the mainland of Asia, and the sea being controlled by the Western Powers, it is evident that as one of the bridges is held by the Slav, possession of the remaining bridge is of vital importance in the struggle between the two great races which adjoin the mainland of the Eastern Hemisphere.

The rivalry is intensified by the fact that the Russians have no ice-free access to the sea, and that the unoccupied bridge leading eastward is crossed by the only waterway leading from Russia southward. The spotthe Straits of Constantinople-therefore, while it is essential to the Teuton for reaching the land, is yet more essential to the Russian for reaching the sea. So long as free commercial expansion is dependent on governmental occupation, the two claims are as natural and just as they are incompatible. Hence the importance of the bridge at the narrow point where it is most easily held.

Position of Turkey in relation to Europe.
The main cause of the whole trouble is the existence in European society of the Turkish Empire-an alien, incompatible entity, opposed to progressive civilisation, incapable of rational government, attached to obsolete conceptions of theccratic feudalism, ignorant of the first principles of judicial administration, and addicted to making spasmodic efforts for welding together heterogeneous elements by means of brute force and massacre. 
Given a State such as this is, geographically situated between the East and the West, exercising a precarious dominion over an all-important waterway that connects two great seas and serves as a vital artery of commercial intercourse between many nations, doing but little herself to develop the resources offered by this wonderful natural canal, disposed to enter into the sinister policy of secret transactions and ambiguous relationships, readily influenced by the doubtful arts of foreign diplomacy-when we consider all these circumstances we need not wonder that Turkey has been the cause of so much jealousy, rivalry, and hostility between the leading Powers of Europe, of so much scheming and counterscheming, of so many disastrous combinations and counter-combinations. Now one Power has predominated in the counsels of the Porte, now a second, now a third; and with the inevitable oscillations of this dismal game of international diplomacy the pendulum has swung back to this State, then to that State and so on, ever engendering strife and warfare. Latterly the influence of Germany has been supreme at Constantinople, having displaced that of Russia; and it is not too much to say that this Germanic penetration into the dominions of the Sultan is virtually responsible as the proximate cause for the outbreak of the present war.

The essence of the Straits problem is this-what Essence of status should be conferred on the Bosphorus and the problem. Dardanelles in order to assure to all countries such freedom of navigation in these waters as will facilitate their commercial intercourse and safeguard their interests? And-as a corollary - who is to be the guardian of the Straits that will earry out the régime involved, and impart confidence to the rest of the world that it will be carried out uniformly, equitably, and faithfully? Under the existing arrangement the waterway is subject 
to the sovereignty of the Sultan; navigation for the commercial flag is, nominally, free, but is interdicted to the military flag, though the Porte is empowered to admit warships of friendly and allied Powers for the purpose, if deemed necessary, of enforcing the stipulations of the Treaty of Paris, 1856. But, as we shall see, mercantile shipping has frequently been interfered with; and as to foreign warships, the arrangement is no longer tenable because, first, it is obnoxious to the interests of various nations, particularly those having coasts on the Black Sea-Russia being, of course, pre-eminent-and secondly because the Sultan has proved incapable of executing the régime, has not infrequently violated his engagement and betrayed the international trust placed in him.

The Black

Sea as a 'chaste and pure virgin.'

Position of Russia.
Formerly, when the territories surrounding the Black Sea and those adjacent to the Bosphorus, the Sea of Marmara, and the Dardanelles, formed part of the Ottoman dominions, the problem of the Straits could not arise, inasmuch as they could legitimately be closed to all foreign vessels. The 'ancient rule of the Ottoman Empire' then rested on valid grounds. To foreign navigators who sought access to the Euxine the Sultan, as sole master, was entitled to reply, as he was wont to do, that the Black Sea was a 'chaste and pure virgin' inaccessible to alien interlopers.

But this condition of things could not continue in view of the growth of Russia and the extension of her empire towards the south. The increase in her population is a significant index of her development and expansion: in 1722 it was about 14 millions, in 1815 about 45 millions, and in 1912 over 170 millions. Her Baltic coasts being icebound for half the year made it necessary for her to obtain an unimpeded outlet into the Black Sea, and thence into the Mediterranean. This 
advance to the south was the national policy inaugurated by Peter the Great, and prosecuted by his successors, most vigorously by Catherine II.

Thanks to the conquests of Peter the Great on the Policy of Black Sea, Russia was enabled to place for the first time Russia with (1696) a warship on its waters, but by the Peace of the Turkey and Pruth, 1711, she was compelled to restore to Turkey the outlets. conquered territories. The aim of Russia was now to regain the position thus lost. In the meantime Austria made annexations at the expense of the Sultan (1718). In the Persian War, 1722-3, Russia co-operated with Turkey, but soon afterwards made an alliance against her with Austria (1726). Catherine II., who posed as the champion of the Greek Church, was a bitter enemy of the Porte, and achieved a triumph by the Treaty of Kutchuk-Kainardji, 1774, which conferred great powers on Russia in regard to Ottoman affairs. There were already discussions in 1769 between Russian and Prussian diplomatists as to the fate of the Turkish Empire; and before the conclusion of the latter treaty a plan was submitted to Catherine for expelling the Turks from Europe and setting up a Greek Empire under a Russian grand-duke. In the succeeding wars Russia made further conquests which were confirmed by the Peace of Jassy, 1792. Towards the end of the century Russia, and also England, joined Turkey as against France; Russian warships were then permitted to pass the Straits-an auspicious precedent in the eyes of the Tsar. A scheme for the partition of the Sultan's dominions was favoured by Paul (1800), who then allied himself to France, in order to overthrow British power in the East. 'This policy was reversed by Alexander I.; and Kotchoubey's view (1802) that it was advantageous for Russia to preserve a weak Turkey was accepted. However, soon afterwards there were Franco-Russian 
negotiations (1807) for the partition of the latter, but they proved fruitless. After the treaties of Tilsit (1807) and Erfurt (1808), followed the Peace of the Dardanelles (1809) with England, to the annoyance of France and Russia; the latter treaty marks an important stage in the Straits question-England agreed to respect the ' ancient rule of the Ottoman Empire,' and the Sultan engaged to exclude all foreign military flags. Next Russia gained great advantages by the Treaty of Akkerman, 1826, and especially by the Peace of Adrianople, 1829 ; and, following on her intervention in the revolt of Mehemet Ali, signed the Treaty of Unkiar-Skelessi, 1833, which, it was thought, practically made Turkey a Russian vassal, and constituted for Russia a great step forward in the solution of the Eastern and the Straits question. Anglo-French protests were made against the transaction. The rivalry between England and Russia in the East was now becoming increasingly manifest. However, the latter's declaration in favour of maintaining the Turkish Empire led to an understanding with England. The Powers then intervened in the renewed conflict between Mehemet Ali and Mahmud, and signed the Treaty of London, 1840, which recognised the ' ancient rule of the Ottoman Empire' and required the Sultan to enforce it; the Russian advantages gained in 1833 were thereby cancelled. The Straits Convention of 1841 made the rule part of European public law, and established the system of collective guarantee. Henceforth, in her Turkish policy Russia had to reckon with the other Powers, on juridical as well as on political grounds. She had now tried alternately forcible methods and diplomatic methods to reach her object; her victories and her diplomacy alike brought her to within an ace of untying the difficult knot, but just at the critical moment it grew tighter in her hands. The 
panslavist policy of Nicholas I. led him to suggest to England the partition of the 'sick man'; but his hopes were dashed to the ground by the Crimean War: the Treaty of Paris, 1856, interdicted the Black Sea to the military flag, Russian or other, and the Straits Convention of the same date again closed the Straits to warships. Russia found the increased restrictions most obnoxious. She was determined to extricate herself from the intolerable position as soon as possible. The hopeless death-struggle of France in 1870 provided her with an opportunity, and on October 31 Prince Gortchakoff, assured of Bismarck's support, issued his historic circular denouncing the offensive clauses of the treaty of 1856 , which prohibited Russia from establishing a navy in the Black Sea. The Treaty of London, 1871, recognised this denunciation, but maintained the principle of clasing the Bosphorus and the Dardanelles to foreign warships. The Russian Chancellor had hoped also to destroy the Sultan's authority over the Straits and open them to all vessels; but the British and Ottoman delegates at the Conference of London succeeded in reducing to a minimum the concessions to Russia, and a mistake in tactics. on the part of Brunnow left the Sultan's power unimpaired. Thus Russia regained the right to maintain a fleet in the Black Sea, but was compelled to keep it imprisoned there. In 1872-3 a Russo-German rapprochement was effected, which augured well for the renewed ambitions of Russia in regard to Constantinople and the Straits. The panslav movement was growing apace, but now it found itself opposed by panislamism. The rising of the Christian population in the Balkans (1875), as a result of Mussulman maladministration and oppression, gave Russia a pretext for intervention in Turkey. The Russo-Turkish War, 1877-8, followed, and the victories of Russia permitted her to dictate terms at San 
Stefano. But the signal advantages gained thereby were once more defeated by the Powers at the Congress of Berlin, which, so far as the Straits were concerned, confirmed the rule of 1871 , despite the efforts of Russia to modify it. The experiences of Russia in the pursuit of her inveterate policy were not inaptly described by Bismarck as an alternation of the 'cold douche' and the 'hot douche.' Gortchakoff had confidently relied on the concurrence of the 'Iron Chancellor,' but he met with a bitter disappointment. In recent years Russia made great efforts to secure for her warships a free passage through the Bosphorus and the Dardanelles; and to achieve her aim she exhausted all the arts of diplomacy and all the devices of political combinationsfirst she tried co-operation with Germany and Austria as against Turkey, then, putting the Central Powers aside, endeavoured to effect an understanding with Turkey and the Balkan States, and finally, leaving Turkey too, sought an alliance with the Balkan States alone. But in every case she suffered a check, owing to the opposition of the Powers. The interests of Austria, who regarded the western Balkans as her own sphere for territorial aggrandisement, were diametrically opposed to Russian policy. Great Britain, having regard to her Far Eastern interests, has throughout been the supporter of the Sultan's independence and the opponent of Russian designs on his dominions; though recently her attitude with regard to the passage of warships in the Straits appears to have changed. From about 1900 the influence of Germany began to preponderate at Constantinople; and her interests in Asia Minor, together with her encouragement of Abdul Hamid's panislamism, constituted a serious obstacle for Russia.

The Straits
question must The Straits question, then, remains unsolved. Under question most
be sod. 
transactions, the Sultan is legally empowered to exclude at his discretion all foreign warships from the Bosphorus and the Dardanelles, and so the southern Russian fleet remains imprisoned in the Black Sea. Moreover, owing to differences in interpretation, the present juridical status of the Straits is not quite clear. Now this international waterway, apart from its strategic position, is of the greatest importance to many Powers, as well as to the new States in the Black Sea, viz.-Bulgaria and Roumania. The existing arrangement is no longer tenable, and it has imposed an intolerable hardship on Russia. The 'ancient rule of the Ottoman Empire,' which has so long been factitiously bolstered up, is now a glaring anomaly. A new régime is urgently called for. Our task, therefore, is to trace the rise and development of this question of the Bosphorus and the Dardanelles, and to set forth the solution that will best satisfy the needs of the society of nations at large. But before doing so, it is necessary, for purposes of comparison, to consider very briefly the position under international law and usage of waterways in general. 


\section{CHAPTER II.}

THE POSITION OF WATERWAYS IN GENERAL UNDER

INTERNATIONAL LAW.

The high sea. The high sea is free and common to the navigation and innocent use of all mankind; it cannot be appropriated or subjected to the exclusive sovereignty or jurisdiction of any State. The designation 'high sea' is, however, used in two senses : first, as the sea below lowwater mark, and secondly, as the open sea beyond the limit of waters generally regarded as territorial. If the term is used in the first sense, the principle of 'freedom of the sea' is subject to special restrictions applicable to 'territorial waters,' which include the littoral or marginal sea, inland seas, gulfs and bays, certain straits, and interoceanic canals. Further, using the term in either sense, the principle is subject on the one hand to certain rights of jurisdiction on the high seas possessed by every State, e.g. over its own vessels, pirates, foreign vessels committing certain kinds of offences, foreign vessels with regard to which treaty rights exist, and in case of war the right of a belligerent to visit and search neutral vessels; and, on the other hand, it is subject to certain common rules of navigation.

The territorial sea.

The territorial sea (or as it has been variously called the littoral, marginal, or jurisdictional sea) (a), was in earlier days claimed by certain States and jurists to extend to exaggerated limits, based on artificial or

(a) H. Bonfils, Manuel de droit international public (Paris, 1912), $\S 491$. 
fantastic measures. Under the influence of writers, such as Grotius and Bynkershoek, a more reasonable view came to be adopted; the latter was the first to formulate an acceptable principle, viz. that the jurisdiction of a maritime State should end where the effective control of its shore batteries ends-' potestatem terrae finiri ubi finitur armorum vis'(b). Nearly all the authorities are agreed as to the rational nature of this limit under common law. But owing to the possibility of variations and hence of inequality, most States have by their internal legislation and by international conventions agreed to fix the limits of the territorial sea to a distance of three marine miles from low-water mark, though for certain special purposes some States have extended it more or less. All vessels have the right of innocent passage through the territorial sea, subject to the right of belligerents to regulate such passage or forbid it on the ground of self-defence, and to the right of neutrals to regulate the passage of warships.

Inlets on the coast of a single State are usually con- Inlets. sidered to be territorial, and therefore under the local jurisdiction. But opinion is not unanimous as to the necessary width of the inlet at its point of junction with the open sea. The predominating view is that it should not exceed six miles; but in certain cases various States make, on the basis of immemorial custom, wider claims which are for the most part acquiesced in by other Powers.

Lakes and land-locked seas which do not directly Lakes and communicate with the ocean, and which are entirely seas. surrounded by the land territory of a single State, are territorial. But if such a sea or lake is bounded by more than one State, then it follows, from the general principle applicable to the open sea, that all have equal

(b) De dominio maris, c. 2. 
rights of free navigation thereon and rights of jurisdiction in their respective littoral zones. The view held by some authorities that such a sea belongs, in the absence of special conventions, to the various littoral States in proportional parts, the boundary lines running through the centre, is less acceptable. An example of a conventional arrangement is furnished by the Caspian Sea: by the treaties of Gulistan (1813) and Tourkmantchai (1828) between Persia and Russia it was placed under the control of the latter, which alone is empowered to maintain warships on it.

An inland sea connected with the main ocean by a navigable channel or strait is not, properly, a closed sea, unless all its shores and both sides of the channel are subject to the same sovereign Power, e.g. the Sea of Azof. If there are several riparian States, then navigation should be free; and the State owning the shores of the channel of communication is not entitled, in principle, to interfere with navigation thereon, beyond requiring the observance of reasonable rules applied uniformly to all for the purpose of facilitating the passage. To exclude vessels from the channel would amount to a violation of the rights of independence and self-preservation of the various riparian States. Actual practice conforms to this principle, though the opinion of publicists is not unanimous. If the channel of communication is broad-according to some over six miles, according to others beyond the power of the possessor to control it by gun-fire-then the sea is obviously an open sea, a 'mare liberum.'

The Baltio Sea.

The Baltic Sea has never been recognised as a closed sea, despite the claims sometimes made by the Northern Powers to exclude belligerents' vessels. Occasionally the neutrality of the sea was stipulated in treaties between the bordering countries, e.g. in 1653 between Sweden 
and Denmark, in 1759 and 1760 between those States and Russia; and in 1780 the declaration of armed neutrality was signed by the same Powers (afterwards joined by others), who held that the Baltic Sea was a closed sea, and engaged to protect it and its coasts from ' all hostilities, piracy, and violence.' But in each case the rule laid down was acquiesced in only for a particular war. That the Baltic Sea is a mare liberum was impliedly admitted in the Treaty of Copenhagen, 1857, and other treaties resulting therefrom.

As to straits in general-apart from special conven- Straits. tions regarding particular straits to which reference will presently be made-the following rules apply :-

(1) If a strait leads to a closed sea, and both its shores as well as that sea belong to one and the same Power, whose shore batteries are able to control it, that Power is entitled to exercise the rights of sovereignty over it, and therefore may exclude foreign warships at all times. But to foreign merchantmen innocent passage should be allowed in the interests of peaceful international commerce.

(2) If a strait of any width whatever leads to an open sea, and both its shores belong to one and the same Power, the latter, in the exercise of its jurisdiction, is entitled to take all necessary measures for its own safety; and therefore may, if it is a belligerent, exclude warships from and prohibit the transport of troops through that strait.

(3) If a strait more than six miles wide separates the territories of different Powers, each of them may exercise the rights of jurisdiction and sovereignty over its territorial waters (that is, to a distance of three marine miles below the low-water mark). If the Strait is less than six miles wide, each Power may exercise such rights to the line running through the mid-channel. 
(4) In every case where there is a right of innocent passage tolls may not be demanded, save such reasonable charges as are necessary for the maintenance of buoys, lighthouses, pilots, \&c. Till 1857 the Sound and the Belts provided an exception to this principle. With the increasing recognition of freedom of navigation, protests were made against the exaction of tolls by Denmark, who claimed that the practice was of immemorial origin and was sanctioned by numerous treaties concluded with various States; thanks, however, to continued persistence, especially by the United States, the right to impose tolls was taken away by the Treaty of Copenhagen, 1857.

Straits of

In the case of the Straits of Magellan, connecting the Atlantic and the Pacific, diplomatic controversies continued for some sixty years between the riparian States, Chile and the Argentine Republic, after their liberation from Spanish dominion. Each claimed exclusive rights of sovereignty, on the basis of the title formerly possessed by Spain. In 1879 the United States Government informed the contending parties that it would not tolerate exclusive claims to the Straits. A settlement was reached by the Treaty of Buenos Ayres, July 23, 1881, which restricted the jurisdiction of both Chile and the Argentine. Art. V. says: 'Magellan's Straits are neutralised for ever, and free navigation is guaranteed to the flags of all nations.' (It may be pointed out that the terms 'neutralisation' and 'neutrality' in regard to the régime established for these Straits, as well as for the Suez Canal and the Panama Canal, are not appropriate; a more precise expression is 'internationalisation') $(c)$. Further, the contracting parties engaged not to construct on the shores of the Straits fortifications and military works.

(c) See infra, p. 239. 
As to the Straits of Gibraltar, the Anglo-French Straits of Agreement, April 8, 1904, respecting Egypt and Gibraltar. Morocco, declared (Art. VII.): 'In order to secure the free passage of the Straits of Gibraltar, the two Governments agree not to permit the erection of any fortifications or strategic works on that portion of the coast of Morocco comprised between, but not including, Melilla and the heights which command the right bank of the River Sebou. This condition does not, however, apply to the places at present in the occupation of Spain on the Moorish coast of the Mediterranean.'

The status of interoceanic canals should, in principle, Interoceanio be assimilated to that of straits, in accordance with the fundamental conclusions set forth above-that is to say, in the absence of special treaty arrangements to the contrary. Therefore such canals, constituting waterways for international traffic, whilst they are under the control and jurisdiction of the State or States in which they lie, should be open not only to the merchantmen but also to the warships of all nations for purposes of innocent passage, subject to the restrictions applicable to the case of straits. Reasonable tolls, however, may be imposed in order to defray the cost of construction and of maintenance. These principles (added to other stipulations) have been expressly applied by international conventions in the régime of both the Suez Canal and the Panama Canal.

Thus the Treaty of Constantinople, October 29, 1888 Suez Canal. (commonly known as the Suez Canal Convention) provides the following rules for the Suez Canal: (1) The canal is to be open in time of war, as in time of peace, to all vessels, whether merchantmen or warships, belonging to either neutral or belligerent States. (2) No acts of hostility are to be committed within the canal or its ports of access, or in the sea to a distance of three 
marine miles from either end of it.

(3) The entrances to the canal are not to be blockaded.

(4) No permanent fortifications are to be erected. (5) A belligerent's warships are not to re-victual or take on stores in the canal, embark or disembark troops, or stay in the canal or ports of access more than twenty-four hours, except in case of necessity as provided; the same provisions being applicable to prizes.

(6) If vessels of different belligerents are in the canal or ports of access at the same time, a period of twenty-four hours is to intervene between the departure of any vessel belonging to one belligerent and that of any vessel belonging to the other. (7) Men-of-war are not to be stationed inside the canal; but each Power, that is not a belligerent, may station two men-of-war in the ports of Suez or Port Said.

Panama Oanal.

The regulations concerning the Panama Canal, as laid down in the Hay-Pauncefote treaty of November 18, 1901 (between Great Britain and the United States), follow substantially those prescribed for the Suez Canal. There is an important difference, however, in that no stipulation is made prohibiting the erection of fortifications. Such a stipulation was embodied in the ClaytonBulwer treaty, 1850, and in the earlier draft of the HayPauncefote treaty; but it was omitted from the existing arrangement, on the ground that it appeared to be incompatible with Art. I. $\S 2$, which empowers the United States to maintain military police along the canal for the purpose of protecting it against lawlessness and disorder. The United States, therefore, may construct fortifications; Art. XXIII. of the treaty of 1903 with Panama expressly recognises the right. 
PART II.

The Evolution of the Rule of the Straits of the

Bosphorus and the Dardanelles.

\section{CHAPTER I.}

FROM THE BEGINNING OF THE CAPITULATIONS TO THE END OF THE EIGHTEENTH CENTURY.

For our present purpose there is no need to trace the history of the Bosphorus and the Dardanelles in antiquity $(a)$ and in the Middle Ages (b). It will suffice merely to say that before the Turks took possession of Constantinople (1453), Italian traders and adventurersnotably the Venetians, Genoese, and Pisans-frequently sailed through the Straits and entered the waters of the Black Sea.

After 1453, however, the Turks having become masters The Black of the Straits, this commercial enterprise met with ${ }_{\text {Tirkish lake. }}^{\text {Sea as a }}$ obstacles. The victorious invaders extended their conquests, fortified the narrower portions of the Straits, and prevented foreign ships from passing through them, except under treaties and other arrangements providing for the payment of tolls or annual tributes and for the observance of various navigation and harbour regulations. By the end of the fifteenth century the Turks had acquired the north coast of the Black Sea, which, being then surrounded by Ottoman territory, was therefore regarded as a Turkish lake subject to the exclusive and jealously

(a) See N. Dascovici, La question du Bosphore et des Dardanelles (Genève, 1915), pp. 1 seq.

(b) Ibid. pp. 13 seq.

p. 
The eystem of apitulations.
Instances of capitulations. guarded sovereignty of the Sultans. By virtue of the persistent policy of imposing restrictions on foreign navigators and excluding from the Straits all ships of war, the rule of closing the Dardanelles and Bosphorus came to be considered a fundamental principle of the public law of the Ottoman Empire.

In course of time-thanks to the enterprise of several maritime nations of Europe and to the inevitable exigencies of commercial intercourse-the transitory and precarious privileges granted to foreign traders were replaced, in the case of certain States, by the system of capitulations $(c)$. These were treaties more regular and more durable in their application though not yet permanent (two centuries were to elapse before this character was definitely attributed to them), whereby on the one hand the subjects of several signatory States acquired the right of trading with Turkish possessions and navigating Turkish waters for commercial purposes, and, on the other, their legal position in the Ottoman Empire was specifically regulated by an application of their personal law. Such conventions were really unilateral, inasmuch as reciprocal treatment was not stipulated.

Of the earlier capitulations the most important was that entered into at Constantinople in February, 1535, between Francis I. and Sultan Soliman II. $(d)$ as a result of the growing menace of the House of Hapsburg to both contracting parties. It confirmed definitively the powers of French consuls and the privileges of French residents. French ships were entitled to sail in Ottoman waters, access to which was denied to the vessels of other States unless they acquired similar treaty rights or sailed

(c) For a concise history of the capitulations, see G. Pélissié du Rausas, Le régime des capitulations dans l'Empire Ottoman. 2 vols. (Paris, 1902-1905); vol. i. pp. 1-127.

(d) Cf. J. Ursu, La politique orientale de François Ier (Paris, 1908). 
under the French flag $(e)$. Five years later the Venetian Republic concluded a capitulation of the same kind. In 1579 Queen Elizabeth entered into a convention (the first conceded to England), which was an exact reproduction of that obtained by Francis I. in $1535(f)$. As the death of a Sultan put an end to the treaties signed by him, express renewal was necessary at the hands of his successor. Sometimes the parties profited by the occasion to obtain an extension of the privileges previously granted. Thus, in 1569 a commercial treaty was concluded between Charles IX. of France and Selim II. ; in 1581 between Henri III. of France and Sultan Mourad; and in 1.593-as also in 1603, 1606, and notably in 1675 - the English convention was renewed. In 1597 France acquired the exclusive right to the protection of all foreigners, except the English and the Venetians, within Ottoman territory $(g)$; and in 1604 the French capitulation was renewed at Constantinople by Sultan Ahmed to Henri IV. who, despite keen English rivalry, remained the protector of the foreigners-the 'Franks' and those of 'Frankish' religion, that is, the Europeans and those of the Roman Catholic religion-and of the Holy Places in Palestine. In 1598 and in 1612 the Netherlands obtained capitulations $(h)$; in 1665 the former commercial treaties with Genoa were renewed and enlarged; in 1673 the French capitulation was renewed at Adrianople between Louis XIV. and Mehemet IV., and additional

(e) Text in G. Noradounghian, Recueil d'actes internationaux de l'Empire Ottoman (Paris, 1897), vol. i. pp. 83-87; I. de Testa, Recueil des traités de la Porte Ottomane avec les puissances étrangères (Paris, 1864, \&c.), vol. i. p. 15. Cf. E. Charrière, Négociations de la France dans le Levant, 4 vols. (1848-1860), vol. i. p. 285.

(f) Noradounghian, op. cit. vol. i. pp. 146-151.

(g) I. de Mouradja d'Ohsson, Tableau général de l'Empire Ottoman. 7 vols. (Paris, 1788-1824), vol. vii. p. 475.

(h) J. Dumont, Corps universel diplomatique du droit des gens. 8 vols. (La Haye, 1726-1731). Supplément. 5 vols. (La Haye, 1739). Vol. v., pt. 2, pp. 205-214. 
privileges were granted to the French sovereign, thus ensuring for his country commercial supremacy in the Levant, in spite of the extended rights acquired by England two years later. Further, the capitulation of 1740 , entered into with Louis XV., was especially noteworthy because of its comprehensive scope (it contained eighty-five articles), but chiefly owing to the novel departure made by providing for its permanent operation $(h)$. In the eighteenth century there were numerous treaties between Austria and Turkey, and between Russia and Turkey, as a result of the frequent wars waged between them; but these were not capitulations, which were essentially conventions of commerce and friendship. The first capitulation proper between Austria and Turkey was concluded in 1718, though a treaty had been entered into in 1616, allowing Austrian merchants to trade with Turkey on certain conditions; and the first between Russia and Turkey was not established until 1783, though there had been treaties of peace in $1711,1720,1739,1774$, in which certain commercial privileges were stipulated. In the meantime other European countries obtained commercial and consular privileges ; e.g. Sweden (1737), the two Sicilies (1740), Tuscany (1747), Denmark (1756), Prussia (1761), Spain (1782), \&c. Thus, by the end of the eighteenth century the Ottoman Porte had concluded capitulations with all the countries of Europe except Switzerland and the States of the Church $(i)$.

Free naviga tion in the Black Sea denied.
In all these treaties, however, save in that with Russia (as we shall presently see), freedom of navigation in the Black Sea was not conceded. Until the Russians established themselves on its shores, the Black Sea was regarded by the Sultans as a Turkish lake that was to be

(h) Noradounghian, vol. i. p. 277.

(i) Cf. Pélissié du Rausas, op. cit. vol. i. p. 96. 
jealously guarded; and Constantinople long remained the terminus of foreign navigators. Notwithstanding the friendship between the French monarchs and the Ottoman rulers, and the existence of numerous French establishments in the Levant, French vessels were not permitted to traverse the Bosphorus. Whatever arguments were advanced by the skilful and persistent negotiators of France, whatever promises were made and undertakings given, the jealous distrust of the Turks (as a French historian remarks) could not be overcome-' la jalouse défiance des Tures ne se laissa pas désarmer' $(k)$.

But the position of Russia was quite different from The position that of France. Possessing extensive continental terri- Russia.

tories and no access to the sea, she realised that it was vitally necessary for her to push her way to the coast and acquire permanent maritime outlets. This became the definitive object of Russian national policy; and to achieve it much treasure was expended and much blood was shed in a long succession of wars. By conquering the Baltic provinces Peter the Great had gained for his country access to the sea in the north; but the waters in these regions being frozen for a great part of the year, a southern outlet became indispensable. Accordingly Russia took advantage of her conflicts with the Tartars of the southern provinces to gain a footing on the shores of the Black Sea. A great thrust forward was made by Peter the Great, and his exertions were continued by his successors Anne and, notably, Catherine. We must now turn our attention, then, to the efforts made by Russia, the opposition she met with on the part of Turkey and intervening Powers, the numerous treaties that were made and unmade, and the alliances and the combinations of States that were established for the purpose of

(k) A. Vandal, Une ambassade française en Orient sous Louis $X V$. (Paris, 1887), pp. 4, 5. 
furthering the aims of this State or preventing the aggrandisement of that State, or for maintaining a particular status quo and political equilibrium.

Conquests of Peter the Great.

In 1696 Peter the Great took possession of Azof, and subsequently placed, for the first time, a Russian warship, the Kriépost, on the Black Sea. By the Treaty of Carlowitz, 1699(l), Turkey was obliged to surrender many of her provinces: nearly all Hungary and Transylvania went to Austria, Podalia and the Ukraine to Poland, the Morea to Venice, and Azof to Russia. Further, the payment of tribute by the Christian States to Turkey was to cease. By this treaty the first dismemberment of the Ottoman Empire was effected, and the interminable sinister policy of intrigues and rivalries among the European Powers in regard to Turkey was inaugurated. Henceforth Turkey, whose military prestige was now destroyed, became 'une combinaison politique indispensable aux intérêts des puissances étrangères' $(m)$. In 1700 Peter the Great despatched for the first time an envoy extraordinary to Constantinople in order to conclude a treaty of peace which, among other privileges, was to secure for Russian shipping the right to navigate the Black Sea from Azof to Taganrog as far as Constantinople. In the course of the negotiations, however, the envoy received the irrevocable decision of the Turkish Government (April 29, 1700) that all foreign vessels would be excluded from the Black Sea, which was regarded by the Porte as a 'chaste and pure virgin inaccessible to everybody' (n). Owing to frequent incursions into Turkish territory by the neighbouring Russians, the Porte, encouraged by the intriguing diplomacy of France

(l) Noradounghian, vol. i. pp. $182 \mathrm{seq}$.

(m) Vandal, op. cit. p. 58 ; cf. F. C. Schlosser, History of the eighteenth century, \&c. English trans. 8 vols. (London, 1843-1852), vol. iii. Introduction.

(n) S. Goriainow, Le Bosphore et les Dardanelles (Paris, 1910), p. 2. 
and Sweden, declared war against Russia, November, 1710. Peter was already engaged in hostilities with Sweden, but, heartened by his victory over Charles XII. at Pultowa and his acquisition of the Baltic provinces and a portion of Finland, he hurried south at the head of an army; and failing to receive the promised support of the Moldavians, he was defeated by the Turkish troops, and was compelled to sign at Falczy the Peace Peace of the of the Pruth, July, 1711, whereby he had to restore Azof (Art. I.) and his other former conquests on the Black Sea (Art. II.), to destroy his fortresses, to refrain from interfering in Polish affairs, and to dispense with the privilege of having an ambassador or other minister at Constantinople (o). To regain the position lost by this treaty became the determined policy of Peter's successors.

Turkey was equally successful against the Venetian Republic in 1715, and conquered the Morea. The following year Venice having concluded a defensive and offensive alliance with Charles VI., the Porte declared war against the latter; but Prince Eugene completely defeated the Ottoman forces and captured Belgrade. By the Peace of Passarowitz $(p)$, July, 1718, Peace of Austria gained a territorial triumph, consolidating her 1718. possession of Hungary and securing Belgrade, the greater part of Serbia and parts of Bosnia and Wallachia. Had Charles VI. abandoned for the time being his western designs and prosecuted the war against Turkey, he would undoubtedly have succeeded in extending Austrian interests on the Danube and in the Balkan States, and would have got ahead of Russia in the race to Constantinople.

In 1722-1723 Russia and Turkey co-operated in the The Peraian

(o) Dumont, Corps Diplom. vol. viii. pt. 1, p. 275.

War, 1722-

(p) De Testa, vol. ix. p. 73 ; Dumont, vol. viii. pt. 1, p. 520. 
Persian War, and in Jume, 1724, concluded a partition treaty. In the subsequent operations against the Afghans the Turks were successful, and similarly against the Persians, who, however, gained a complete victory at the end of 1734. In order to keep the Turks occupied in Persia during the Polish Succession War, the Tsarina Anne formed an alliance with the famous adventurer Nadir Shah, and gave him assistance in his struggle against Sultan Ahmed III. The latter, after some reverses, and in view of the threatening attitude of Russia and Austria, was induced to make peace at Erzerum, 1735, by which he ceded Georgia and Azarbijan, and in the following year Nadir Shah was elected King of Persia.

Russo-

Austrian

alliance against

In the meantime Russia and Austria concluded a treaty of alliance, August, 1726, whereby each was to aid the other in the event of a Turkish war; and having come to an understanding in regard to Poland, they entered into the Treaty of Vienna, 1735, which now rendered possible a concerted attack on Turkey and a further dismemberment of her empire. Thus an excellent opportunity presented itself for wiping out the humiliation suffered by Peter the Great at the Pruth. What with the unneutral conduct of the Porte during the Polish Succession War, the Tartar invasions across the Ukraine borders, and the disputes in regard to certain territories north of the Caucasus, the Tsarina Anne had not far to seek for a casus belli. The Russians now felt more keenly than ever that it was imperative to gain possessions on the Euxine, and obtain a foothold in the rich lands of the Crimea; to consolidate their position in the south by putting down the plundering Tartar hordes that were subject to Turkish rule; to wrest from Ottoman hands the control of the five great waterways - the rivers Dniester, Dnieper, Bug, Don and Kuban- 
and secure the right to pass the Straits of Constantinople both for warships and for merchantmen. Preparations were therefore made for war, and the services of a cosmopolitan assemblage of generals were enlisted, among whom the most remarkable was Marshal Münich. Early in 1736 he invaded the Crimea, whilst Lacy, an Irishman, laid siege to Azof. In January, 1737, Austria joined Russia under a secret alliance; but notwithstanding this combination the. Turks offered a firm resistance. By 1739 Austria was exhausted, and after her defeat at Crocya concluded a separate peace at Belgrade $(q)$ (September 1), under the mediation of the astute French ambassador at Constantinople, Marquis de Villeneuve, who, mindful of his own country's interests, had by his inexhaustible arts of diplomacy succeeded in sowing dissensions between the allies and magnifying the military preparations and resources of the Porte. The fruits of the triumph won by Austria at Passarowitz - were now sacrificed. Russia was unable to continue the campaign single-handed, and, a Swedish attack being imminent, followed the example of Austria and concluded peace at Belgrade $(r)$ (September 18) on the terms proposed by Villeneuve, Russia was obliged to restore her con. quests, except Azof and its district, but its fortifications were to be destroyed, and Russian ships were forbidden access to the Black Sea, so that commerce had to be carried on in Turkish vessels. This peace between Turkey and her obstinate adversaries was considered a signal achievement of French diplomacy; and it was as a reward for the services of Louis XV. that Turkey entered into the great capitulation of 1740 , to which reference has already been made. After the Peace of

(q) Wenck, Codex juris gentium, vol. i. p. 326 ; Noradounghian, vol. i. pp. $243-253$.

(r) Wenck, vol. i. p. 368 ; Noradounghian, vol. i. pp. 258-265. 
Belgrade there was, it may be said, a truce in regard to the Eastern Question for about a quarter of a century. In its stead the war of the Austrian Succession for a time occupied the attention of Europe.

Poliog of
Catherine II. With the accession of Catherine II. (1762) the question was attacked by Russia with redoubled energy and determination. The 'Semiramis of the North' became one of the great founders of the Russian Empire, and was perhaps the most resolute adversary the Ottoman Porte ever had. Desiring to win the sympathies of her subjects, she posed as the champion of the Greek Church, and made it a cardinal principle of her foreign policy to pursue Russian aims in the direction of Poland on the one hand, and Turkey on the other. The treaty of 1764 between Catherine and Frederick the Great, who promised each other aid in case of war and came to an agreement regarding the disposal of the Polish throne, facilitated Russian interposition in Poland. This alarmed Sultan Mustapha.III., who soon found a cause for war in the instigation, by Russian agents, of the Greeks, Bosnians, and Montenegrins against Ottoman rule, and in the pursuit of Polish Confederates by Russian troops Russo-
Turkioh War, 1768 .

gennes, the French ambassador, declared war on Russia, October, 1768-a war that was to prove disastrous to Turkey. Already in $\mathbf{1 7 6 9}$ we find Russian and Prussian diplomatists discussing the fate of the Ottoman Empire, as well as the partition of Poland: Austria was to receive territories in the east, Prussia a part of Poland, whilst Russia would be contented with the dissolution of the Turkish Empire and the establishment of a Turkish Republic $(s)$.

In the autumn of the same year the Russians defeated

(s) Cf. A. Sorel, La question d'Orient au XVIII'e siècle (Paris, 1889), p. 47 . 
the Turks, occupied Moldavia and Wallachia, seized the fortresses of Khotin, Azof, and Taganrog, as well as Bucharest. The following year a Russian expedition, under Alexis Orloff, was despatched from Cronstadt to the Black Sea. Aided by British officers, notably Elphinstone, the Russian admiral defeated the Turkish fleet off Scio and annihilated it off Tchesmé (July 5, 7). The land forces were also successful, capturing Bender, Ismail, Kilia, Akkerman, and Braila, and-in 1771-Kerch, Eupatoria, Perekop with the whole Crimean peninsula. The Russian military progress alarmed the European Powers: England did not wish Russia to secure the passage of the Bosphorus; Prussia was afraid of being dragged into a conflict with Austria ; and France, having urged Turkey to make war, hoped for Russian exhaustion, not triumph $(t)$. The European tension was relieved, however, by the first partition of Poland, whilst England was herself occupied with the American difficulty. In 1773 Turkey, fearing Russian designs on Constantinople, rejected peace terms that were offered and continued the struggle; but in consequence of further defeats, ending in the rout at Shumla, she was obliged to sue for peace. Catherine, meeting with internal troubles due to the rising of Pugachoff, consented to cease hostilities, and concluded the Treaty of Kutchuk- Treaty of Kainardji (July 22, 1774)(u) which, though not satis- Kainardji. fying her eastern ambitions, was one of the most advan1774. tageous transactions ever effected by Russia $(x)$. The Voltaireans and the Encyclopædists, several of whom were on terms of friendship with the Russian Empress, acclaimed the treaty as a prelude to the re-establishment

( $t$ ) Cf. Recueil des instructions données aux ambassadeurs et ministres do France, vol. ix. ; La Russie, pt. 2, p. 267.

(u) Noradounghian, vol. i. pp. $319-334$; G. F. de Martens, Recueil des traités (1st ed.), vol. i. p. 507 ; vol. iv. p. 607.

(x) Cf. Sorel, La question d'Orient au XVIIIe siècle, pp. 252 seq. 
of the Greek Empire. Indeed, some time before its conclusion, Potemkin presented a project to Catherine for expelling the Turks from Europe and establishing a Greek Empire under a Russian grand-duke.

The treaty, indeed, conferred great powers on Russia. Thugut, the Austrian envoy at Constantinople, observed that the stipulations taken in their entirety testified to the diplomatic ability of the Russian negotiators and to the imbecility of the Turkish. By a skilful combination of the Articles the Turkish Empire wellnigh became a Russian province $(y)$. Russia claimed to have thereby acquired a moral and juridical right of intervention in the internal affairs of the Ottoman dominions, and a civilising mission in general in the interests of all the Christian populations subject to Mussulman rule $(z)$.

However this may be, Russia soon came to the con= clusion that the advantages derived from the Treaty of Kutchuk-Kainardji were inadequate, inasmuch as ber liberty of navigation in the Black Sea and the Straits. depended on the will of the Sublime Porte, which was itself swayed by the tortuous policy and unending machinations of the representatives of the Powers at Constantinople, and therefore lacked permanence and security. Moreover, the same commercial privileges as had been wrung from Turkey by means of costly wars began to be conferred on other countries. Accordingly Catherine felt that a more drastic arrangement was indispensable for the natural expansion of Russian commerce and dominion. Not long after the treaty of 1774 was concluded, Russia began to intervene in Turkish affairs; but the Ottoman Government offered resistance and prepared for a resumption of hostilities. Eventually a

(y) Cf. Sorel, op. cit. p. 263.

(2) Cf. F. de Martens, Etude historique sur la politique russe dans la question d'Orient, in Revue do droit international et de législation comparée (Bruxelles), 1877 (vol. ix.), pp. 60, 77. 
convention was agreed to (1779) (a) under the mediation of Saint-Priest, the French ambassador, whereby the provisions of the Treaty of Kutchuk-Kainardji were confirmed and made more explicit, the privileges of navigation in the Black Sea were amplified, Turkish authority in the Danubian provinces was restricted, and Potemkin's nominee was recognised as Khan of the Crimea.

A defensive alliance having been concluded with Joseph II., June, 1781, Catherine addressed herself once more to her anti-'Turkish policy.-me following year Russian troops invaded and annexed Crimea; and England acquiescing and France being occupied in the west-in January, 1784 , the Treaty of Constantinople $(b) \underset{\text { Treaty of }}{\text { Constanti. }}$ was signed, by which Turkey recognised the annexation nople, 1784. of the Crimea and the Kuban. Immediately afterwards (February, 1784) Austria obtained from the Porte the right of free passage for her commercial flag(c). In 1786 the intrigues of the Tsarina's agents in the Ottoman dominions were resumed; and the following January, with the view of re-establishing a Greek Empire at Constantinople, the Empress undertook her famous journey to the Crimea, met the Polish king on her way, was crimeal, ${ }_{1787}$. joined by Joseph II. at Kherson (April), had medals struck designating her 'Propugnatrix Fidei,' and at Sebastopol saw with pride a powerful navy created by herself. Presently the Russian ambassador submitted fresh demands to the Ottoman authorities, who retorted with a counter-proposal involving the restoration of Crimea; when the former pointed out that he was not empowered to sign a document to this effect he was

(a) Martens, Recueil (1st өd.), vol. iii. p. 349 ; Noradounghian, vol. i. p. 338.

(b) Noradounghian, vol. i. pp. 377, 378 ; Martens, Recueil (1st ed.), vol. ii. p. 505 .

(c) Noradounghian, vol. i. pp. $379-382$. 
thrown into prison, and then the Porte, relying on the

War with support of England and Prussia, declared war. France

Tarkey, 1788.

deciding to remain neutral, Austria joined Russia (February, 1788). In the campaign of 1789 Turkey suffered severe defeats, but was saved only by the confusion in the Austrian dominions and by the intervention of the Triple Alliance (Great Britain, Prussia, and the Netherlands). Conformably to the Convention of Reichenbach, July, 1790, Austria withdrew from the Turkish war by the Peace of Sistova (August, 1791). Russia, though deprived of her ally's support, continued the conflict, took Ismail (December, 1790), gained successes in the Kuban and Caucasus, captured Akkerman and Kilia (September, 1791) - thus becoming mistress of the mouths of the Danube-and won a naval victory in the Black Sea.

Plans were now elaborated for proceeding against Constantinople $(d)$; but Catherine, desiring to prosecute her Polish policy whilst Austria and Prussia were occu-

Peace of Jaspy, 1792. pied with France, concluded peace at Jassy (January 9, 1792) (e), which confirmed the Treaty of Kutchuk-Kainardji, extended the western boundary of Russia to the Dniester, and gave to Russia all the coast of the Black Sea between that river and the Bug, as well as the fortress of Ochakoff. Catherine's long-cherished plans were thus progressing, though at an enormous expense; and it was only her death (November 17, 1796) that put a stop to her tenacious determination-to the very last she thought and spoke of the great blow which was to make her mistress of Constantinople $(f)$. Turkey was by now in a deplorable condition; misrule and dissen-

(d) Cf. E. Laloy, Les plans de Cathérine II. pour la conquête de Constantinople (Paris, 1913), pp. 1-3.

(e) Martens, Recueil (lst ed.), vol. v. p. 53 ; Noradounghian, vol. ii. pp. $16-21$.

(f) Laloy, op. cit. pp. 5 seq. 
sion brought about anarchy, and arbitrary assumption of power by the pashas $(g)$. It is doubtful whether she would have survived the eighteenth century if her enemies' attentions had not been so frequently diverted to Sweden and Poland, and Russia and Austria had not so unceasingly striven over the possession of the Danubian provinces $(h)$.

(g) Cf. W. Eton, Survey of the Turkish Empire (London, 1799), pp. 451 seq.

(h) Cf. S. P. H. Duggan, The Eastern Question. A Study in Diplomacy (New York, 1902) [Studies in History, Economics, and Public Law : Columbia University; vol. xiv. No. 3], p. 34. 


\section{CHAPTER II.}

FROM THE TREATY OF CONSTANTINOPLE, 1798, TO THE TREATY OF BUCHAREST, 1812.

Policy of Catherine's successor, Paul I., found the Russian armies Paul I.

Treaty of CampoFormio, 1797. disorganised, the population impoverished, and the national finance in difficulties. He was, therefore, in favour of peace, and of advancing the Turkish policy by means of diplomacy. The encouragement given by the French Directory to the Poles, and the activities of Bonaparte forced the Tsar to abandon his pacific attitude. The Treaty of Campo-Formio (October, 1797) gave to the French the Ionian Islands ; this cession, followed by the conquest of Malta and the Egyptian expedition, made France a menace to Russia who reserved to herself alone the right to interfere in the East. When, therefore, the Sultan appealed to Paul for assistance, it was readily given. A fleet under Admiral Ouchakoff set sail for Constantinople, and, with the authorisation of the Porte, entered the Bosphorus (September 5, 1798). A Russo-Turkish convention was quickly drawn up (October), which was converted into the definitive nople, 1798 . Treaty of Constantinople (December 23, 1798)(a). A few days later (January 5, 1799) England became a party to the treaty. This alliance between Russia and Turkey was to remain in force for eight years; each undertook to protect the possessions of the other; Russia was to furnish to the Porte a squadron of twelve vessels of the

(a) Noradounghian, vol. ii. pp. 24-31; Martens, Recueil (1 st ed.), vol. vii. p. 314. 
line, and if necessary an army of seventy-five to eighty thousand men, and Turkey was to provide for the maintenance of the whole. But-Turkey agreed also to the free passage of Russian warships through the Straits-a provision eagerly taken advantage of by Russia and subsequently invoked as a precedent. By the combined action of the Russo-Turkish fleets, the French were obliged to withdraw from the Ionian Islands. At this time Russian warships, regardless of the treaty restrictions, passed the Straits frequently, not confining themselves to the military operations against Napoleon $(b)$.

The Russian alliance with Turkey was not effected for the benefit of Turkey. In 1800 Count Rostopchin scheme to formulated a scheme in which he proclaimed that the Trurkey, 1800 . dismemberment of the Ottoman Empire was the only solution of the Eastern Question and the only national policy of Russia. Turkey, he said, was an invalid condemned irrevocably to death, and the measures adopted by her for her preservation were only potions putting off for a brief space her inevitable end. His plan of partition was to this effect : Russia was to obtain the largest share $=$ Roumelia, Bulgaria, and Moldavia, that is, including the west coast of the Black Sea; AustriaBosnia, Serbia, and Wallachia ; Prussia-Hanover, Niederburg, and Münster; France-Egypt ; Greece and the archipelago to be united as a Republic under the protection of the four Powers, and later, the Greeks would of their own accord put themselves under the dominion of Russia. In this division England was to get no share at all. Paul was in favour of the scheme; and at the beginning of 1801 he allied himself to France, as against England, in order to invade India across Asia and overthrow English power in the East. The grandiose

(b) Cf. Pisani, L'expédition russo-turque aux îles Ioniennes, in Revue d'histoire diplomatique (Paris, 1888), pp. 190 seq.

P. 
project, however, was not to be put into operation. For, Paul's insanity growing worse and his behaviour more and more unpopular, a band of nobles, disapproving of his war policy, resolved to put an end to his tyranny; in the night of March 23-24 he was approached by a number of conspirators, and refusing to sign an act of abdication, was struck down and strangled.

AlexanderI.'s The new emperor, Alexander I., was in favour of policy, 1801 . friendship with England; and his Turkish policy was, in September, 1801, thus formulated by him-the preservation by every possible means of the Ottoman Empire, whose internal weakness and disorganisation Kotchoubey's rendered it impotent to do harm to Russia. Furtherreport, 1802 . more, the following year, the minister Count Victor Kotchoubey presented to the Tsar a report which laid down, as a fundamental principle of imperial politics, that it was an advantage for Russia to have weak neighbours. He emphasised that only two courses were open: either to accelerate the dissolution of Turkey and share her dominions with Austria and France, or to preserve her existence by warding off every menace conducive to dismemberment; that of these alternatives the latter was preferable. The Turks being quiet and harmless neighbours, it was essential to maintain their enfeebled sovereignty over the Straits (c). The view advocated by Kotchoubey was accepted, and, as we shall see, it was adopted in practice in the case of the famous Treaty of Unkiar-Skelessi (1833).

Peace between Soon after the Peace of Amiens was concluded by France and Turkey, England and France (March 25, 1802), Turkey made peace with France (June 25, 1802) $(d)$, whereby (among other stipulations) the Porte's possession of Egypt and

(c) Dascovici, op. cit. p. 150 ; referring to G. Gigareff, La politique russe dans la question d'Orient (Lausanne, 1897), p. 307.

(d) Noradounghian, vol. ii. pp. 51-53; De Testa, vol. i. p. 495. 
all its territories was recognised, and the French capitulation of 1740 was renewed with additional provisions giving the French commercial flag the right to traverse the Straits and navigate the Black Sea without restriction. Some years before the expiration of the Russo-Turkish alliance of 1798, the Ottoman Porte proposed negotiations for its renewal. Accordingly the Russian minister, Italinsky, at Constantinople was charged to establish a close union with Turkey, with a view to her participating in a possible coalition against France, and to secure for Russia the right of intervention in Turkey in order to protect the Christian subjects of the Sultan and ameliorate their position $(e)$. The instructions despatched to the Russian ambassador included a draft treaty, consisting of seventeen patent Articles and eight secret. According Projected to the latter Turkey was to co-operate with Russia and Great Britain to prevent the realisation of Napoleon's coalition against Napoleon. designs against the Ottoman dominions, to expel the French from Italy, and to facilitate the passage through the Bosphorus and the Dardanelles of Russian warships sailing from the Black Sea to the newly-established Republic of the Ionian Islands. In the course of his negotiations Italinsky urged the maintenance of Art. X. of the Treaty of Constantinople, December 23, 1798 , which closed the Straits to the warships of other countries. He observed, in his report to his Government, that if he did not insist on an express renewal of this provision, the English would certainly obtain a passage for their vessels of war to the Black Sea, and their example would be followed by the French $(f)$. Accordingly he secured the

(e) Goriainow, op. cit.pp. 4, 5.

(f) 'J'ai cru devoir conserver cet article parce que, s'il n'est pas renouvelé, infailliblement les Anglais qui, malgré son existence, ont à plusieurs reprises tenté d'introduire leurs bâtiments de guerre dans la mer Noire, comme Nelson l'a fait tout récemment et précédemment lord Elgin qui, à cet effet, avait déjà fait monter une frégate jusqu'à Boujoukdéré, ne manqueraient pas d'insister pour obtenir ce point, et 
insertion in the projected secret convention of the following clause, whereby the Straits were closed to the military flag of every nation, opened to the Russian, and were to be defended by the contracting parties in case any other armed ship attempted to enter: 'Les deux hautes parties contractantes sont convenues de considérer la mer Noire comme fermée et de n'y permettre l'apparition d'aucun pavillon de guerre ou bâtiment armé de quelque puissance que ce soit, et, dans le cas où quelqu'une d'elles tenterait d'y paraître en armes, les deux hautes parties contractantes s'engagent à regarder une pareille tentative comme casus foederis et à s'y opposer de toutes leurs forces navales, comme étant l'unique moyen d'assurer leur tranquillité réciproque; bien entendu que le passage libre par le canal de Constantinople continuera d'avoir lieu pour les bâtiments de guerre et transports militaires de S.M. impériale de toutes les Russies, auxquels dans chaque occasion la Sublime Porte prêtera, autant qu'il dépendra d'elle, toute assistance et accordera

Treaty of 1805. toute facilité.' This clause was inserted in the treaty concluded with the Porte, September 11/23, $1805(g)$. Though the Black Sea was now possessed in common by the two signatories-Russia holding the northern and a part of the eastern shores, and Turkey the western and southern shores-the region of vital importance, viz., the Straits, remained under the exclusive sovereignty of the Sultan. But Russian warships acquired the liberty to proceed to the Ionian Islands during the stay of the Russian troops there for the purpose of protecting the

la Porte qui avait un si bon moyen de se refuser à une telle demande, en mettant en avant son engagement avec la Russie, pourrait céder; alors l'exemple des Anglais déterminerait, il n'y a pas à douter, les Français à se frayer un passage pour leurs navires armés, ce qu'ils ont essayé d'obtenir pendant les négociations qui ont eu lieu à Paris pour le traité de paix avec la Porte, comme la cour impériale en a été informée à cette époque.' (Goriainow, pp. 5, 6.)

(g) Noradounghian, vol. ii. pp. 70-77. 
republic. 'En réciprocité de cette marque d'amitié sincère de la cour de Russie, la Porte ottomane, pendant toute la durée du séjour des troupes russes sur le territoire de la république sept-insulaire, facilitera le passage, par le canal de Constantinople, des vaisseaux de guerre russes destinés à remplacer les forces navales qui se trouvent dans lesdites îles ou à ravitailler et relever les troupes qui y sont stationnées' $(h)$.

The treaty of 1805 was entered into for a period of nine years. No sooner was it concluded, however, than Napoleon's capture of the Austrian army at Ulm (October, 1805), and the defeat of the Austrians and Russians at Austerlitz (December, 1805) led to the French triumph by the Treaty of Pressburg (December 26, 1805), and to the despatch of the adroit diplomatist, General Sébastiani, on a special embassy to Turkey. He soon induced the Ottoman Government to recognise the imperial title of Napoleon-viz., that of Padishah-and urged a repudiation of the alliance with Russia and the firm retention of the Danubian provinces, Wallachia and Moldavia. Moreover, Sébastiani drew the attention of the Divan to the passage of the Russian warships through the Straits, Passage of and insisted on a renewal of the old restrictions, despite $\underset{\text { warsians }}{\text { Russian }}$ the authorisation granted by the treaty of 1798 and Straits, 1806. renewed by that of 1805 . A note was accordingly handed to Italinsky, asking him in a friendly manner to stop the passage of the Russian warships (i). The Turkish minister pointed out that Art. IV. of the

(h) Art. IV.

(i) In his despatch to his Government, Italinsky observed : - Quoique ce ne soit pas une réquisition mais une exposition amicale des considérations qui paraissent faire désirer par la Porte le consentement de la cour impériale, il est impossible de ne pas s'arrêter au fait, c'est-à-dire à l'intention assez bien manifestée par la Porte, quoique exprimée avec ménagements, que le seul intéressant article de l'alliance n'ait pas son exécution, et cela dans quel moment, lorsque plus que jamais le passage des bâtiments armés et des troupes est impérieusement requis par les circonstances.' (Goriainow, p. 8.) 
recent treaty of alliance did not apply to the then existing circumstances, because the agreement was made in contemplation of a common and defensive war; therefore to permit Russian naval forces to pass for the purpose of adopting offensive measures against the French possession of the Adriatic would be incompatible therewith. The Russian reply was that the said Art. IV. was clear and precise; that the word 'war' was not mentioned in it; that the question of distinguishing between an offensive and a defensive war did not arise; that the ultimate destination of the Russian forces passing through the Bosphorus and the Dardanelles was no concern of the Porte, which was entitled to ascertain only that the forces needed to pass for the purpose of proceeding to Corfu. Notwithstanding this contention, however, a note of April 14/26, 1806, asked Russia to discontinue the passage of warships. None the less a Russian warship, the Jason, arrived at Constantinople, June 24/July 6, on her way to Corfu. The Ottoman authorities reminded Italinsky of the note, whereupon the latter replied that the Jason was a vessel authorised by the treaty of the preceding year, and that if Turkey was determined to prevent the passage she would have to do so by force, and would therefore be answerable for the consequences. Shortly afterwards, the Russian ambassador was informed that the Porte did not contest the right of passage, and had no intention to offer opposition (k). Again, on July 23, when a Russian frigate, the Kildum, passed the Straits, the Turkish authorities -in consequence of renewed diplomatic pressure from France-requested the Russian minister to stop the passage of warships for the future. Italinsky replied that his Government would continue to do so as long as was necessary; whereupon the Ottoman ministers de-

(k) Goriainow, pp. 9, 10. 
clared that their request was of a purely friendly character, as they feared reprisals at the hands of the French $(l)$.

Sébastiani succeeded in stirring up Turkish feelings Russia's with regard to the Danubian provinces. Notwithstanding the protests and threats of the Russian and the British insistence on the treaty of 1805. minister, the Sultan deposed the hospodars (August 24) -an act which in the eyes of the Tsar constituted a casus belli. Furthermore, the Porte refused to abide by the terms of the treaty of 1805 , and having once more, and this time more seriously, declared its intention to prevent the passage of Russian ships of war, Italinsky was instructed to demand the observance of the treaty, and, in case of refusal, to ask for his passports. Shortly afterwards (October 16), the Russian forces on the Dniester were ordered to invade Moldavia; and Baron Budberg charged Italinsky to obtain a solemn and definitive declaration from the Porte that it would adhere to its former undertaking and abstain from interfering with the passage of Russian warships $(m)$. But before the despatch reached Constantinople the Russian ambassador was required by the Ottoman authorities to leave the capital within three days (December 11/23). Italinsky embarked on an English vessel for Malta, and immediately afterwards Turkey declared war.

(l) Ibid. p. 10 .

(m) 'La prétention de vouloir empêcher les passages des bâtiments de guerre et des transports de sa majesté par le canal de Constantinople, et les difficultés réitérées que la Porte s'est permis de manifester dans des occasions récentes, ne démontrent que trop évidemment l'aveugle soumission du gouvernement turc à la volonté de la France et les écarts incalculables auxquels ces dispositions peuvent l'entraîner, puisqu'il ne respecte déjà plus les traités les plus solennels. Pour obtenir à cet égard une garantio proportionnée à l'importance que nous devons mettre à la conservation de notre droit de passage par le canal, S. M. impériale croit devoir demander une déclaration solennelle et authentique, par laquelle la Porte s'obligera de ne jamais, et dans aucun cas, y porter la moindre atteinte, sous quelque prétexte que ce soit.' (Ibid. pp. 11, 12.). 
Russia being also in conflict with Napoleon in Prussia, now received the support of her ally, Great Britain. The English ambassador in Constantinople first of all demanded the expulsion of Sébastiani; and this demand having been refused, a fleet of eight ships of the line under Admiral Duckworth proceeded to the Dardanelles, and he forced his way past the forts (February 19, 1807). He could now have taken the Ottoman capital, but owing to his irresolution and dilatory tactics the Turks were enabled, under the direction of Sébastiani and the French colony, to construct defensive works and organise every means of resistance $(n)$; so that Duckworth was compelled to withdraw to the Mediterranean (March 2). In the meantime Baron Budberg informed the Grand Vizier that the Russian invasion of Moldavia was due to Turkey's violation of the treaty of 1805 , and proposed that the Porte should enter into an alliance with Russia and England, provided it would observe strictly the existing treaties between the two Empires, and maintain for Russian warships the right of passing the Straits. It was pointed out that the Russian armies were sent towards the Danube, not for purposes of conquest, but to protect Turkey from the designs of France, and that they would evacuate the principalities as soon as Sébastiani was dismissed and the required guarantees given.

Peace of Tilsit, 1807.
Owing to the internal condition of Turkey, however, events took an unexpected turn. The Government was distracted by rebellions in the army and insurrections among the people. In May the Janissaries deposed Sultan Selim and placed Mustapha IV. on the throne. Napoleon then used this revolution as a pretext for reconciling himself with Russia by the Peace of Tilsit

(n) Cf. A. de la Jonquière, Histoire de l'empire Ottoman (Paris, 1881), pp. 398 seq. 
(July 7, 1807) (o), whereby Alexander surrendered Cattaro and the Ionian Islands; and a treaty of alliance was signed on the same day. Conformably to the stipulations of the Treaty of Tilsit, negotiations for ceasing hostilities were begun and an armistice was signed at Slobodsia, August 12/24, 1807.

At the end of 1807 certain Franco-Russian negotiations Franotook place in regard to the partition of the Ottoman nugsotiations Empire $(p)$. At first Count Rumiantseff, the Russian of Turkey, minister, assured General Savary, the French ambassador 1807. at St. Petersburg, that Alexander did not desire any aggrandisement $(q)$. On November 7 Napoleon himself had an interview with Count P. Tolstoi, the Russian ambassador at Paris, and discussed various proposals, including the partition question $(r)$. It appears to have been Napoleon's aim to postpone the partition till the moment when England would not be in the position to demand the richest share, viz., Egypt and the archipelago $(s)$. The discussion between the two Governments continued for nearly three months, but no agreement could be reached. as to the Danubian principalities. In February, 1808, Caulaincourt, the new French ambassador at St. Petersburg, submitted to the Tsar a plan suggested by Napoleon relative to the partition, together with the latter's proposal for an expedition against India $(t)$. On March 1 Alexander suggested to Caulaincourt that Constantinople should be made a free town. 'Constantinople,' he said, ' est un point important pour nous. J'ai une idée: pour que cela ne fasse pas de difficultés, faisons-en une espèce

(o) Cf. A. Vandal, Napoléon et Alexandre Ier (Paris, 1891), vol. i. chap. 1.

(p) S. Tatistcheff, Alexandre Ier et Napoléon d'après leur correspondance inédite, 1801-1812 (Paris, 1891).

(q) Ibid. pp. 222, 223.

(r) Ibid. pp. 238, 239, 243.

(s) Ibid. p. 254.

(t) Ibid. p. 307. 
de ville libre' $(u)$. The very next day, however, Rumiantseff, the foreign minister, adopted a contrary attitude, asserting that in view of its geographical position and Russian commercial interests the Ottoman capital, together with a certain extent of surrounding territory, including the Straits, must go to Russia: 'Constantinople, par sa position, par la nôtre, par tous les intérêts de notre commerce dont la clef est au Bosphore et aux Dardanelles, nous revient, ainsi qu'un grand territoire qui comprenne ces points' $(x)$. It was imperatively essential, he emphasised, that Russia should have both Constantinople and the Straits: 'L'une sans l'autre, ce n'est rien. C'est la géographie et notre mer Noire, plus encore que notre intérêt politique, qui veulent que nous ayons Constantinople' $(y)$. At a subsequent meeting the French ambassador proposed that his country should take the Dardanelles, but the Russian minister objected $(z)$. Similar views were set forth at the next conference, with the same result; then the French representative suggested that an independent and neutral State should be constituted in the Straits territory, but Rumiantseff opposed the suggestion (a). Finally, the Russian minister urged that the Straits should go to Russia, and the Asiatic side of the Dardanelles to France; whereupon Caulaincourt now submitted that France should take the Dardanelles and that an independent Government should be established in the Ottoman capital (b) he pointed out later that if Russia gained possession of the Dardanelles she would soon be at the gates of Corfu and Toulon $(c)$. Thus no agreement was arrived at in

(u) S. Tatistcheff, Alexandre Ier et Napoléon d'après leur correspondance inédite, 1801-1812 (Paris, 1891), p. 322.

(x) Ibid. p. 329.

(y) Ibid.

(z) Ibid. pp. 335-338.

(a) Ibid. pp. $343-347$.

(b) Ibid. pp. 351, 352.

(c) Ibid. p. 413 . 
these partition discussions. Preparations were now being made for the famous interview at Erfurt, when it was mentioned that Napoleon was emphatically of the opinion that whilst the Black Sea should become Russian, the Mediterranean should become French; and that in order to realise this object an intermediary State should be constituted at Constantinople as a barrier against possible encroachments on the part of Russia $(d)$.

On October 12, 1808, the Treaty of Erfurt was con- Treaty of cluded between Alexander and Napoleon, as against Great Britain.

In the meantime the rapprochement between France Peace of the and Russia at Tilsit had alarmed Turkey. It seemed as Dardanelles, though the Tsar, now that he had become reconciled to the French Emperor, would have a free hand in the East, and that the Porte could no longer count on French support to resist his designs. Accordingly, Turkey turned to England, and the latter, for her own part, was desirous of cementing Anglo-Ottoman relationships. The result was the Treaty of Constantinoplesometimes called the Peace of the Dardanelles $(e)$ (January 5, 1809), which displeased both France and Russia $(f)$. The Porte, mindful of the recent appearance of the British fleet before Constantinople, stipulated. in Art. XI. that Great Britain should observe the 'ancient rule of the Ottoman Empire,' which the Porte undertook to apply to all Powers, whereby warships of overy flag were prohibited from entering the Straits of the Bosphorus and the Dardanelles ('le canal de Constantinople'). Turkey thus insisted on her exclusive right of sovereignty over the Straits, and in order to

(d) Vandal, Napoléon et Alexandre Ier, vol. i. pp. 271, 272.

(e) Noradounghian, vol. ii. p. 81 ; E. Hertslet, Commercial Treaties, vol. ii. p. 371.

(f) Cf. Sir Robert Adair (who negotiated the treaty), The negociations for the Peace of the Dardanelles in 1808-9. 2 vols. (London, 1845.) 
fortify it introduced the expression (which appears to have been used here for the first time), ' ancient rule of the Ottoman Empire'-an expression that was afterwards frequently repeated, and not only by Turkey, according to the exigencies of State interest arising in the remarkable vicissitudes of European political relationships. It may be said that this provision constitutes the germ of the international rule laid down in the Straits Convention of 1841. Whilst recognising Turkish sovereignty over the Straits, and enunciating the 'ancient' rule which denied access to all warships, it actually restricted that sovereignty by imposing an obligation on the Sultan to close the Straits to all military flags in return for the obligation assumed by Great Britain to observe the rule. That is, Great Britain undertook to respect a rule which, in view of Ottoman sovereignty, she was in any case bound to respect: she merely agreed in an express contractual form to refrain from doing what she was not entitled to do under the common law. On the other hand Turkey, considering her sovereignty, was not bound to engage herself to permit or exclude the passage of this or that vessel. But having deliberately undertaken to exclude all warships, she thereby limited her liberty of action, that is, her sovereignty. Though this engagement concerned, juridically speaking, only the two parties to it, it contributed much to transform what was originally a rule of Ottoman internal administration into a rule of international law ; moreover, it facilitated British intervention in Turkish affairs, and the establishment of political combinations to which Turkey attached herself, now to one, now to another, for the purpose of opening the Straits to this State or closing them to that State. As a French writer aptly says: 'La Porte, désormais, secouée par des crises successives, ballottée entre le péril russe 
et le péril anglais, va se servir de la fermeture ou de l'ouverture des détroits comme d'une monnaie d'échange pour gagner la protection de l'une ou de l'autre des grandes puissances; mais le commandement des Dardanelles et du Bosphore, qui avait été le plus bel apanage de l'Empire turc, passe de plus en plus aux mains des étrangers; les droits de la Turquie sont grevés de servitudes de plus en plus lourdes; l'Europe, par une série de traités, tend à se substituer áu Sultan; mais, selon les vicissitudes de la fortune, e'est tantôt contre la Russie et tantôt à son bénéfice que la Porte est invitée à exercer ses droits de garde; tant bien que mal les formules du droit s'accommodent aux fluctuations de la politique' $(g)$.

Turkey, relying on British support, now renewed hos- The Treaty of tilities against Russia (March, 1809). On April 10 the 1812.

Porte issued a notification forbidding all intercourse with Russia by sea or by land; but the act called forth protests, e.g., from the French Government. The Russians defeated the Turks at Braila and Silistria (1809), occupied Moldavia, Wallachia, and Bessarabia (1810), crossed the Danube and occupied Silistria and Shumla (1811), and were preparing to march on Constantinople. Thanks to Napoleon's preparations to invade Russia, the Tsar agreed to make peace with the Porte. On May 16/28, 1812 , the Treaty of Bucharest $(h)$ was signed, under the mediation of Stratford Canning $(i)$. Moldavia and Wallachia were thereby restored to Turkey; Russia acquired Bessarabia, her frontier was advanced to the Pruth and to the Kilia branch of the Danube; and existing treaties between the signatory parties were confirmed (Art. III.).

(g) R. Pinon, La mer Noire et la question des Détroits, in Revue des deux mondes, Oct. 15, 1905, p. 809.

(h) Noradounghian, vol. ii. pp. 86-92; British and Foreign State Papers, vol. xiii. p. 908 ; Martens, Nouveau Recueil, vol. iii. p. 397.

(i) S. Lane Poole, Life of the Right Hon. Stratford Canning, 2 vols. (London, 1888), chap. 4. 
But no provision was made regarding the Straits, nor was there any mention of the right of passage that had been conferred on the Russian military flag by the Convention of 1805. However, in virtue of the extension of the Tsar's territory in this direction, this treaty marks an important stage in the evolution of the Eastern Question. But it did not satisfy Alexander, who was anxious to make an alliance with the Porte as against France and her allies. This point of view is shown in a communication of the Tsar (May 14) addressed to Admiral Tchitchagoff: 'Il ne faut se dissimuler que la paix conclue par le général Koutousow présente des inconvénients. Le général a négligé un point très important, c'est de n'offrir les concessions que nous avons faites dans nos prétentions qu'à condition d'une alliance offensive et défensive. Ce n'est que cette alliance qui pouvait nous dédommager de la gêne que va mettre cette paix dans nos rapports avec les Serbes et les nations slaves. Si un moyen pouvait encore - se présenter pour obtenir l'alliance avec la Porte et sa coopération, surtout par les Serbes et les nations slaves, contre la France et ses alliés, il ne faudrait rien négliger à cet effet' $(k)$.

(k) Goriainow, p. 24. 


\section{CHAPTER III.}

TREATIES OF ADRIANOPLE, 1829, AND UNKIARSKELESSI, 1833.

VARIOUS events of the greatest importance to European politics must now be passed over, such as, for example, the settlement of Europe by the Congress of Vienna and the formation of the Holy Alliance (1815), the renewal of the Quadruple Alliance (November, 1815) between England, Russia, Austria, and Prussia. The Tsar's deliberate exclusion of Turkey from the Holy Alliance was based, ostensibly, on the ground of her fundamental incompatibility with the rest of Europe in regard to religion, public life, government, legal conceptions, and civilisation in general. To the other Powers, however, it seemed that Alexander was contemplating a fresh onslaught on the Ottoman dominions. Their attitude to Turkey was not as uncompromising as that of Russia, who refused to regard her as a member of the European society of nations. It is true that it was not till the Treaty of Paris, 1856, that the Porte was formally admitted into the European system and was expressly recognised as sharing in the relative rights and obligations; but long before this date the European States, other than Russia, considered Turkey, in their relationships with her, as virtually occupying such a position.

In the meantime Russia was growing in population and in commerce; her military power was increasing considerably, and her navy was being enlarged; and her political position in Europe was becoming more important than ever. The Ottoman Government viewed 
this with great concern, and always remained distrustful of Russian policy. Greek revolt, The revolt of Ali, Pasha of Janina, against the Sultan
1821. offered a favourable opportunity for the outburst of the Greek revolt (March, 1821), which was stimulated by the propaganda of the secret society, the Hetairia Philike, established at Odessa in 1814, whose object was to revive the Greek Empire of Byzantium. The leaders, under Prince Hypsilanti, expected the active support of the Russian Government in addition to its sympathy; but the Tsar, at the instance of some of the European Powers, notably England and Austria, disavowed the revolutionary movement, which collapsed soon after it broke out (June, 1821). But the insurrection in the south was more successful. By the end of the year nearly the whole of the Morea was in the hands of the insurgents; the revolution then spread throughout Greece, and reached even Thessaly and Macedonia. With the course of the war of Greek Independence, however, we are not here concerned.

Turkish sovereignty over the Straits.

Greek vessels under Russian flag seized
The following notification issued by the Sublime Porte in 1822 shows that the Sultan was anxious to emphasise his sovereignty over the Straits and that foreign shipping passing them in order to proceed to the Black Sea did so only in virtue of express disposition's in treaties: 'The Ottoman minister has communicated to the ministers of the Powers, whose fiags have the right of entrance to the Black Sea, a firman of the Grand Seigneur from the date of which the passage of the Bosphorus is closed to the ships of nations to whom the Porte has never accorded the right of entry to that sea. These Powers are requested not to lend their flag to facilitate their passage.'

Russo-Turkish friction was soon renewed, through the seizure in the Dardanelles of Greek vessels flying the 
Russian flag, the refusal of the Ottoman Government to in the withdraw its military forces from the Danubian provinces Dardanelles. conformably to treaty stipulations, and the execution of the Greek Patriarch, together with two of his bishops, in retaliation for massacres committed by the Greeks. The Russian people clamoured for war, which Alexander, mindful of his solemn peace protestations, was desirous of avoiding; but, owing to pressure from his ministers, he broke off diplomatic relations and called upon the Sultan to make reparation. Thanks to the interposition of Metternich and the British ambassador at Constantinople, a conciliation was effected whereby Turkey agreed to evacuate the Principalities, and to observe the existing rights of the commercial flag of foreign Powers in the navigation of the Straits. However this may be, it was felt that as a result of these events Russian prestige at Constantinople was considerably diminished.

The Ottoman Government having failed to fulfil its Treaty of engagements with Russia, the new Tsar, Nicholas I., 1826. sent an ultimatum (March 17, 1826) to Sultan Mahmud. The result was the Treaty of Akkerman (a) (October 7) conceding to Russia her demands relative to the evacuation of the Principalities, the cession of certain Circassian fortresses, and the unrestricted enjoyment by the Russian commercial flag of liberty of navigation in all Ottoman waters.

By the Treaty of London, July 6, 1827, Great Britain, Russia, and France agreed to intervene in the Eastern conflict, and secure the autonomy of Greece under the suzerainty of the Sultan. The allied fleets, under Codrington, having in vain demanded of the Pasha Ibrahim that he should cease hostilities on land, withdraw the Ottoman and Egyptian fleets, and evacuate

(a) Noradounghian, vol. ii. pp. 116-121; Sir E. Hertslet, Map of Europe by treaty. 4 vols. (London, 1875-1891), vol. i. p. 747.

$\mathbf{P}$. 
the Morea, a dispute occurred because of the refusal of the Turks to move some fire-ships that menaced the allied vessels in the Bay of Navarino; this was followed by a general battle, and the annihilation of the Mussulman armada (October 20)-though no official instructions for commencing an attack had been issued. The Porte described this conduct as an outrage, proclaimed a Holy War (December 20), and declared the Treaty of Akkerman null and roid. This gave Nicholas the opportunity he was seeking. On January 6, 1828, he notified his intention of occupying the Danubian Principalities with or without the consent of Great Britain; but the latter protested that such a proceeding would bring about the downfall of Turkey and the outbreak of a European war. Soon afterwards the Russian Government promised to regard the Mediterranean as neutral, and sent an army across the Pruth (May 6, 1828). In the following year (October) Russia, forgetting her promise, proclaimed a blockade of the Dardanelles-an act which called forth a strong protest from Great Britain as being contrary to the previous Russian announcement, as well as a menace to British commerce. Thanks to the strategy of the Russian commander, Diebitsch, the Turks were out-manœuvred, and were

Peace of Adrianople, 1829. compelled to sign the Peace of Adrianople (b) (September 14, 1829), which constituted a brilliant triumph for Russian policy. Besides effecting a settlement of Greek affairs, the treaty assigned Anapi and Poti to Russia, made the Danubian Principalities practically independent, and confirmed existing treaties, more particularly the treaty rights of Russia in regard to her subjects' freedom of trade in Turkey, and freedom of navigation

(b) Noradounghian, vol. ii. pp. 166-173; Hertslet, Map of Europe, vol. ii. p. 813 . Cf. generally, T. Schiemann, Geschichte Russlands unter Kaiser Nikolaus I. (Berlin, 1904-1907), vol. ii. 
in the Straits and the Black Sea. Art. VII. embodying the latter provision is, for our purpose, the most important; it is as follows :-

'Russian subjects shall enjoy, throughout the whole Freedom of extent of the Ottoman Empire, as well by land as by Trarkey. sea, the full and entire freedom of trade secured to them by the treaties concluded heretofore between the two high contracting Powers. This freedom of trade shall not be molested in any way, nor shall it be fettered in any case, or under any pretext, by any prohibition or restriction whatsoever, nor in consequence of any regulation or measure, whether of public government or internal legislation. Russian subjects, ships, and merchandise, shall be protected from all violence and imposition. The first shall remain under the exclusive jurisdiction and control of the Russian minister and consuls; Russian ships shall never be subjected to any search on the part of the Ottoman authorities, neither out at sea nor in any of the ports or roadsteads under the dominion of the Sublime Porte; and all merchandise or goods belonging to a Russian subject may, after payment of the custom-house dues imposed by the tariffs, be freely sold, deposited on land in the warehouses of the owner or consignee, or transhipped on board another vessel of any nation whatsoever, without the Russian subject being required, in this case, to give notice of the same to any of the local authorities, and much less to ask their permission so to do. It is expressly agreed that the different kinds of wheat coming from Russia shall partake of the same privileges, and that their free transit shall never, under any pretext, suffer the least difficulty or hindrance.

The Sublime Porte engages, moreover, to take $\begin{gathered}\text { Free passage } \\ \text { to Russian }\end{gathered}$ especial care that the trade and navigation of the Black merchant Sea, particularly, shall be impeded in no manner whatsovessels in the Straits. 
ever. For this purpose it admits and declares the passage of the Strait of Constantinople and that of the Dardanelles to be entirely free and open to Russian vessels under the merchant flag, laden or in ballast, whether they come from the Black Sea for the purpose of entering the Mediterranean, or whether, coming from the Mediterranean, they wish to enter the Black Sea; such vessels, provided they be merchant ships, whatever their size and tonnage, shall be exposed to no hindrance or annoyance of any kind, as above provided. The two Courts shall agree upon the most fitting means for preventing all delay in issuing the necessary instructions. In virtue of the same principle the passage of the Strait of Constantinople and of that of the Dardanelles is declared free and open to all the merchant ships of Powers who are at peace with the Sublime Porte, whether going into the Russian ports of the Black Sea or coming from them, laden or in ballast, upon the same conditions which are stipulated for vessels under the Russian flag.

Freedom of trade and navigation in the Black Sea.
Lastly, the Sublime Porte, recognising in the Imperial Court of Russia the right of securing the necessary guarantees for this full freedom of trade and navigation in the Black Sea, declares solemnly, that on its part not the least obstacle shall ever, under any pretext whatsoever, be opposed to it. Above all, it promises never to allow itself henceforth to stop or detain vessels laden or in ballast, whether Russian or belonging to nations with whom the Ottoman Porte shall not be in a state of declared war, which vessels shall be passing through the Strait of Constantinople and that of the Dardanelles, on their way from the Black Sea into the Mediterranean, or from the Mediterranean into the Russian ports of the Black Sea. And if, which God forbid, any one of the stipulations contained in the present article should be 
infringed, and the remonstrances of the Russian minister thereupon should fail in obtaining a full and prompt redress, the Sublime Porte recognises beforehand in the Imperial Court of Russia the right of considering such an infraction as an act of hostility, and of immediately having recourse to reprisals against the Ottoman Empire.'

The Treaty of Adrianople conferred great advantages Effect of the on Russia with regard to Turkey. The privileges of Adrianople. her subjects in the Ottoman dominions were extended, and surpassed even those acquired by French subjects in the great capitulation of 1740. Some years before the conclusion of the treaty Russia had determined (as we shall see presently) to extract from the Porte the right of passage for her warships ; but this determination was not realised, as she had to reckon throughout, not only with opposition from the Sultan, but with firm resistance from the leading maritime Powers of Europe. However, the Tsar now secured entirely undisturbed navigation for his commercial flag; no hindrance whatever was to be imposed on his merchantmen passing the Straits, no right of visit and search was to be exercised; and it was actually stipulated - a provision of this kind being of raré occurrence in international documents - that any act of interference should be considered a violation justifying recourse to reprisals. Whether, by insisting on such a stipulation, the Russian Government contemplated the circumvention of the inveterate veto of the Porte as to the passage of vessels of war by despatching warships under the commercial flag, it is difficult to say; but we know that at a later epoch Russia more than once made use of such a device.

In 1826 Russia thought that the existence of the War Russia's of Greek Independence offered a good opportunity for efforts to obtaining the right of passage for her military flag. military flag. $^{\text {for her }}$ 
Among the papers of Count Nesselrode there is a draft for a future treaty with Turkey, in which is found an Article conceding the right, so long as not more than two warships pass at once, and not more than four assemble in the 'canal of Constantinople' (nothing being said as to the number in the Dardanelles): 'Toutes les côtes de la mer Noire étant placées sous la domination exclusive des deux empires et la cour impériale de Russie ayant à cœur d'accorder forte et constante protection à ses bâtiments marchands qui naviguent dans l'archipel, en employant à cet effet les vaisseaux de la flotte qu'elle entretient dans la mer Noire, S. M. le Sultan des Ottomans, en témoignage de la haute confiance qu'il place dans les dispositions amicales de S. M. l'empereur et padishah de toutes les Russies, consent à ce que les vaisseaux de guerre russes de la flotte de la mer Noire puissent passer librement par le canal de Constantinople et le détroit des Dardanelles pour se rendre dans l'archipel et en revenir, à condition, toutefois, que ce passage ne puisse avoir lieu que pour deux vaisseaux de guerre à la fois et que jamais plus de quatre de ces vaisseaux ne pourront se trouver ensemble dans le canal de Constantinople' (c).

Treaty

between

Soon after the Peace of Adrianople was signed, a

United States treaty was concluded between the United States and and Turkey, 1830.

Turkey (May 7, 1830), of which Art. VII. accorded to merchantmen of the United States, in the same way as to those of 'the most favoured nation,' the liberty to pass the 'canal of the imperial residence,' and to enter and leave the Black Sea either laden or in ballast. No mention was made of warships.

Revolt of Mehemet Ali, 1831 .

The next stage in the development of the Straits Question is due to the revolt of Mehemet Ali and the consequent intervention of Russia in Ottoman affairs.

(c) Goriainow, pp. 27, 28. 
That cunning Albanian adventurer, after making himself ruler of Egypt in 1831, invaded Syria the following year; his son, Ibrahim Pasha, of Navarino fame, inflicted numerous defeats on the Turks, and by his complete victory at Konieh, December 21, 1832, brought Turkey to the verge of downfall. In the meantime the Emperor Nicholas sent Lieutenant-General Muravieff as

special envoy to Egypt, with the object of persuading Mehemet Ali to be reconciled with the Sultan. The Instructions delivered to Muravieff pointed out that if the sovereign rebel triumphed French influence in Constantinople would be increased, designs against Russia would be promoted, the advantages acquired by the Treaty of Adrianople would be lost, and Russia would have a strong neighbour instead of a weak-for her policy demanded the existence of a weak, stationary Turkey: 'Les succès de Méhémet-Aly prépareront une catastrophe funeste à l'empire ottoman. Quelles que soient les conséquences que cet événement amènerait à sa suite, elles ne resteraient point étrangères à la Russie, car les avantages directs que la Russie doit au traité d'Andrinople pourraient se trouver exposés à être remis en question. L'empereur aurait été obligé de reprendre, malgré lui, une attitude menaçante envers la Turquie pour la défense de ses droits. Avec le triomphe de Méhémet-Aly augmenterait l'influence française à Constantinople, qui deviendrait bientôt le foyer où iraient se réfugier tous les hommes sans principes et sans patrie qui conspirent contre la Russie. Enfin, pour résumer toutes les conséquences que ce nouvel ordre de choses nous présage, il suffira de dire qu'avec Méhémet-Aly la Russie verrait succéder un voisin fort et victorieux à un voisin faible et vaincu. Toutes ces considérations réunies ont porté notre auguste maître à penser qu'il est de l'intérêt bien entendu de son empire de contribuer, 
's'il se peut, à prévenir la chute du Sultan et de maintenir ainsi la 'Turquie dans l'état stationnaire où elle se trouve, combinaison qui se concilie le mieux avec le système de politique permanent ainsi qu'avec les considérations de prudence qu'on ne saurait perdre de vue au milieu de l'incertitude qui pèse sur les affaires d'Occident. Pénétré de l'importance de cette vérité, l'empereur a résolu de se prononcer hautement contre l'insurrection du vice-roi et user de toute son influence pour en arrêter le progrès' $(d)$.

Mission of Muravieff.

Muravieff was to explain to the Porte that his mission was neither an offer of assistance nor even of intervention, but simply a step taken by the Tsar for the purpose of bringing about tranquillity in the Ottoman Empire. At the same time Admiral Greigh was ordered to be ready with his Black Sea fleet.

On the arrival of the envoy at Constantinople (December $9 / 21$ ) the Porte evinced its gratitude and delight; but a few days later deep-seated distrust altered its attitude, when he left for Alexandria. Ibrahim Pasha's victorious march towards the capital, however, terrified the Sultan, who therefore appealed to the Powers. England and Austria declined to interfere, whilst France espoused the cause of Mehemet Ali. The Porte was thus obliged to turn to Russia alone, and asked for the despatch of an army as well as of a squadron (January $21,1833)$. The Tsar readily consented to give the required support, and ordered a military expedition to be prepared. A few days later Muravieff returned from Egypt, bringing the Pasha's promise to cease hostilities. The activity of Mehemet Ali's adherents in Constantinople, guided by the French legation, counteracted the Russian influence with the Porte, which, believing that the peril was at an end, asked that the despatch of the

(d) Goriainow, pp. 29, 30. 
army and the squadron should be countermanded. But on February 8 a squadron of nine vessels reached Buyukdere, though, at the instance of Admiral Roussin, the French ambassador, it was removed to Sizopol, a little to the north of the capital. The following month Russian troops landed, and encamped near Buyukdere, in the valley of Unkiar-Skelessi.

These vigorous proceedings on the part of the Russian Convention of Government alarmed Europe. England and France Kiuta. thought it necessary to co-operate in order to bring the intestine war to an end, and before Russia had gone too far in her intervention; Austria, too, moved; so that in view of this combined opposition Ibrahim signed the Convention of Kiutayeh (April 8, 1833), whereby the Sultan ceded Syria and Adana to Mehemet Ali.

In connection with these events the Tsar's attitude The Tsar's towards Turkey and the Powers is seen in various attitude Russian diplomatic documents. When Count Orloff was Turkey. appointed to succeed Boutenieff as ambassador at the Ottoman capital, he was instructed to do his utmost to secure the confidence of the Sultan, to combat French influence, to aroid collective intervention, to show that Russia's aim was to preserve Turkey, and that her troops would withdraw as soon as all danger was gone: 'Notre politique devra adopter les combinaisons suivantes: (1) déterminer la Porte à placer dans l'appui de l'empereur une confiance absolue et légitimer par là aux yeux de l'Europe notre assistance matérielle, ainsi que la position militaire que nous prenions en Turquie; (2) combattre l'influence de la France à Constantinople avec énergie et avec habileté, sans provoquer gratuitement une rupture ouverte; (3) démontrer clairement, par notre conduite et notre langage, que l'action matérielle de la Russie dans les affaires de Turquie est dirigée vers un but de conservation, afin de nous concilier par là l'appui moral de 
l'Autriche, tout en neutralisant, d'un autre côte aussi, les intentions malveillantes que l'Angleterre ne cesse de manifester à notre égard; (4) persister à agir à Constantinople, comme nous l'avons fait jusqu'ici, avec une entière indépendance et sans prêter la main à aucune intervention collective, combinaison qui ne ferait que nuire à la liberté et à la force de notre action et finirait par compliquer nos rapports avec les autres puissances intervenantes; enfin, (5) maintenir notre attitude militaire dans les états ottomans, jusqu'à la conclusion d'un arrangement définitif entre la Porte et l'Egypte et jusqu'à la retraite de l'armée d'Tbrahim-Pacha au-delà du mont Taurus, retirer alors notre escadre et nos troupes, ainsi que l'empereur l'a hautement annoncé. Dans cette supposition, l'objet le plus important de votre mission consistera, sans doute, dans le soin que vous mettrez à inspirer au Sultan et à ses ministres la conviction que leur salut dépend uniquement de l'appui généreux de l'empereur. Afin de vous faciliter le moyen d'agir puissamment à cet égard sur l'esprit du divan, sa majesté a jugé indispensable de manifester aux yeux de la Porte toute l'étendue des pouvoirs dont vous êtes investi. Car il est certain que le Sultan ne pourra placer dans vos assurances et dans votre appui une confiance illimitée que lorsqu'il vous verra en mesure de le protéger efficacement' $(e)$.

Nicholas asks for Turkey's oonfidence.
Orloff had also a letter for the Sultan, in which Nicholas emphasised that his squadron remained in the waters of the Bosphorus solely in the interests of Turkey, and he asked for the fullest confidence in Russian policy: 'Depuis deux mois la présence de l'escadre russe est devenue pour la capitale de l'empire ottoman une garantie de conservation, et depuis, je n'ignore pas ce qu'un tel état de choses doit avoir pour

(e) Goriainow, pp. 33, 34. 
la Sublime Porte de nouveau et d'inattendu. Durant plus d'un siècle elle a considéré la Russie avec inquiétude et méfiance. Il était réservé à votre hautesse de mieux juger les vrais intérêts de son empire en reconnaissant enfin que la Turquie, pour être paisible et prospère, a besoin de pouvoir compter sur l'amitié de la Russie. De tous les souverains qui se sont succédé sur le trône de Constantinople vous avez été le premier à placer une noble confiance dans la loyauté de la politique russe. Je saurai justifier cette confiance. Mais pour qu'elle soit salutaire, elle doit être accordée sans réserve; toute hésitation entraînerait les conséquences les plus fatales. Il importe dans ce moment décisif que votre hautesse elle-même veuille bien m'aider à combattre les desseins de ses ennemis en s'ouvrant franchement à moi, au milieu des dangers qui l'environnent' $(f)$.

When Orloff arrived at Constantinople (April 26, 1833) he found that Ottoman policy was, as usual, in a vacillating condition, now inclining to Russia, now turning away from her. Indeed, the complicated tangle of diplomatic moves and counter-moves at Constantinople, the interminable jealousies and intrigues, would have rendered consistent action very difficult even in the case of a Government much more united and decisive than that of the Ottoman Empire. Orloff described the Sultan as weak-willed and of little consequence, and observed, in a letter to Count Nesselrode (May 12, 1833): 'With the Turks one must caress with one hand and hold a clenched fist with the other' $(g)$.

At this time Admiral Roussin tried every means to Efforts of secure for the French military flag access to the Dar- Fecure to passage danelles; and the Porte refusing permission, an attempt was actually made (May 2/14) - but it proved unsuc-

(f) Ibid.pp. 34, 35 .

(g) Ibid. p. 36. 
cessful-by the warship, Mésange, to force a passage through the Straits. The Russian ambassador thereupon declared that if foreign warships entered the Straits, he would be obliged to take every possible measure to defend the capital. In a private letter to Nesselrode (May 17) he observed, that he had succeeded in emboldening the Turks to stand their ground against Roussin, who was forced to promise that he would not enter the Dardanelles. The Turks were in a state of perplexity, and were at one time on the point of asking the English and French ambassadors to despatch to Constantinople their Mediterranean fleets. 'I stopped this folly by saying that their whole policy should be to divide these two, rot to unite them in any way whatever; ultimately they understood, and were grateful.' If Roussin were to enter the Straits under the orders of his Government, and without the authorisation of the Porte, his action would reveal to Europe 'la politique perfide et frauduleuse' of France; if he did so on his own responsibility, he would compromise himself and compel his Government to disavow him. After paying a tribute to the honourable conduct of Lord Ponsonby, Orloff concluded by emphasising that Russia must be prepared for every eventuality $(h)$. Secret Rasso-
Turkish Secret Russo-Turkish negotiations were now going on for the conclusion of another treaty. Russia was resolved to make her influence predominate at Constantinople. A despatch from Nesselrode to Orloff (May 8, 1833) spoke of a defensive alliance to protect Turkey and the southern coasts of Russia, and mentioned a secret clause specifying the part to be fulfilled by the Porte in consideration of Russia's promised services: ' Il y aurait un avantage réel à profiter de nos relations actuelles avec la Porte, afin de la lier par une stipulation

(h) Goriainow, p. 37. 
formelle qui fût de nature à nous procurer une sûreté de plus pour rendre ináttaquables les provinces méridionales de l'empire qui bordent la, mer Noire. Une pareille sûreté, c'est en réalité la seule compensation qu'il soit au pouvoir du Sultan de nous offrir en retour des services qu'il a reçus et qu'il attend encore de la Russie. Sous ce rapport, il ne sera pas inutile de faire sentir aux conseillers intimes du Sultan que c'est nommément pour ménager la dignité de ce souverain que, dans notre projet de traité patent, nous avons eu soin de considérer comme réciproque le secours que les deux parties contractantes s'engagent à se prêter. Or, comme les circonstances ne comportent pas que la Russie puisse attendre un secours effectif de la Turquie, cette dernière est tenue en honneur d'offrir, du moins, au gouvernement impérial un certain équivalent de l'assistance matérielle qu'elle en reçoit. $\mathrm{Au}$ fond, cette stipulation n'impose à la Porte aucune charge nouvelle, car dans tout état de cause elle est intéressée, par sa propre sécurité, à tenir fermée l'entrée des Dardanelles aux bâtiments de guerre étrangers, et le principe se trouve posé de fait et consacré par l'usage de tout temps. Ce ne sera donc point une obligation onéreuse pour la Porte que de constater et de confirmer, par une stipulation expresse, l'existence d'un principe auquel elle a tenu invariablement. Cet engagement est l'objet d'un article secret pour ne pas compromettre en rien la Turquie envers les autres cabinets et n'exciter, ainsi, aucune récrimination. L'empereur attache un grand prix à cette clause, car c'est lui qui l'a suggérée par un sentiment de juste préroyance' $(i)$.

The Russian activity and the growing subservience of British alarm' Turkey to Russia were not unobserved. 'It is manifest,' wrote Lord Ponsonby (May 22), "that the Porte stands as to Turkey'a subservienoe to Russia. in the relation of vassal to the Russian Government';

(i) Ibid. p. 40. 
and it was his belief that an arrangement had been arrived at between Russia and Austria for the partition of Turkey. Moreover, despite the conclusion of the Convention of Kiutayeh, preparations went on at Odessa for the despatch of additional troops; the fortifications of the Dardanelles were-being improved under the supervision of Russian officers, and six warships of the Tsar were authorised to pass the Straits. In consequence of these preparations the British Government thought it expedient to despatch a squadron to Turkey; and it was its sudden appearance at Tenedos that induced the Turkish ministers (who had not been aware of the negotiations conducted by the Sultan and Ahmet Pasha) to accept, under the pressure of Orloff, the terms of the projected alliance. Accordingly, on June 26/July 8, 1833, the famous Treaty of UnkiarSkelessi $(j)$ was signed; and no sooner were the signatures affixed to the document than the Russian forces began their withdrawal.

Treaty of Unkiar-

Skelessi, 1833.

The provisions of this treaty, which played a great part in the political vicissitudes of the Eastern Question, and more particularly in those of the Straits Question, are as follows :-

Peace, amity, 'ART. I. There shall be for ever peace, amity, and
and alliance. alliance between His Majesty the Emperor of All the Russias and His Majesty the Emperor of the Ottomans, their Empires and their subjects, as well by land as by sea. This alliance having solely for its object the common defence of their dominions against all attack, their Majesties engage to come to an unreserved understanding with each other upon all the matters which concern their respective tranquillity and safety, and to

(j) Noradounghian, vol. ii. pp. 229-231; Hertslet, Map of Europe, vol. ii. p. 925 . 
afford to each other mutually for this purpose substantial aid, and the most efficacious assistance. ART. II. 'The treaty of peace concluded at Adrianople $\begin{gathered}\text { Confirmation } \\ \text { of treatiea. }\end{gathered}$ on the 2/14 September, 1829, as well as all the other treaties comprised therein, as also the Convention signed at St. Petersburgh on the 14/26 April, 1830, and the arrangement relating to Greece, concluded at Constantinople on the $9 / 21$ July, 1832, are fully confirmed by the present treaty of defensive alliance, in the same manner as if the said transactions had been inserted in it word for word.

ART. III. In consequence of the principle of conservation and mutual defence, which is the basis of the present treaty of alliance, and by reason of a most sincere desire of securing the permanence, maintenance, and entire independence of the Sublime Porte, His Majesty the Emperor of All the Russias, in the event of circumstances occurring which should again determine the Sublime Porte to call for the naval and military assistance of Russia, although, if it please God, that case is by no means likely to happen, engages to furnish, by land and by sea, as many troops and forces as the two. high contracting parties may deem necessary. It is accordingly agreed, that in this case the land and sea forces, whose aid the Sublime Porte may call for, shall be held at its disposal.

ART. IV. In conformity with what is above stated, in Maintenance the event of one of the two Powers requesting the of land and assistance of the other, the expense only of provisioning Power requesting the land and the sea forces which may be furnished, shall fall to the charge of the Power who shall have applied for the aid.

ART. V. Although the two high contracting parties Duration of sincerely intend to maintain this engagement to the the treaty. most distant period of time, yet, as it is possible that in 
process of time circumstances may require that some changes should be made in this treaty, it has been agreed to fix its duration at eight years from the day of the exchange of the imperial ratifications. The two parties, previously to the expiration of that term, will concert together, according to the state of affairs at that time, as to the renewal of the said treaty.

Ratification. ART. VI. The present treaty of defensive alliance shall be ratified by the two high contracting parties, and the ratifications thereof shall be exchanged at Constantinople within the space of two months, or sooner if possible.

The

Dardanelles to be closed to foreign warships during war between Russia and any other foreign

Power.

Separate and Secret Article. In virtue of one of the clauses of Art. I. of the patent treaty of defensive alliance concluded between the Imperial Court of Russia and the Sublime Porte, the two high contracting parties are bound to afford to each other mutually substantial aid, and the most efficacious assistance for the safety of their respective dominions. Nevertheless, His Majesty the Emperor of All the Russias, wishing to spare the Sublime Ottoman Porte the expense and inconvenience which might be occasioned to it by affording substantial aid, will not ask for that aid if circumstances should place the Sublime Porte under the obligation of furnishing it, the Sublime Ottoman Porte, in place of the aid which it is bound to furnish in case of need, according to the principle of reciprocity of the patent treaty, shall confine its action in favour of the Imperial Court of Russia to closing the strait of the Dardanelles, that is to say, to not allowing any foreign vessels of war to enter therein under any pretext whatsoever.

The present separate and secret Article shall have the same form and value as if it was inserted word for word in the treaty of alliance of this day.'

In the discussion of the secret clause, the Ottoman 
negotiators had proposed that the Dardanelles should be closed to all foreign vessels of war having hostile intentions against either of the negotiating parties. This proposal was rejected by Orloff, who says he detected the motive underlying it, and convinced the Turkish Government that its adoption would be equivalent to nullifying the very advantage which Russia hoped to derive in return for her own engagement to Turkey. He pointed out, too, that it was not his country's intention to drag in the Porte in a war that might break out with third Powers, or to cause it to cease friendly relations with them; for all that was demanded was the closure of the Straits to warships alone $(k)$.

This secret Article conferred on Russia a great, and at the same time a novel, advantage, which one might well fail to notice on a hasty perusal, especially so in view of the defective drafting. Russia really stipulated therein that, in consideration of her material assistance to Turkey, the latter should forbid access to the Straits to the warships of third Powers 'in case of need'-' au besoin.' As a recent historical writer observes : 'In the ambiguity of the last phrase lay the whole sinister significance of the treaty' $(l)$. The insertion of this

(k) 'Il me fut aisé de relever l'inconvenance d'une pareille clause en faisant sentir qu'elle détruirait le seul et légitime avantage, que la Porte était appelée à offrir par réciprocité à la Russie, et qu'en outre il serait contraire au simple bon sens que la Porte prenne l'engagement de s'opposer à une agression directe contre elle-même, puisqu'il était clair que son propre intérêt lui prescrivait d'en agir ainsi. J'ajoutai qu'il n'était, d'ailleurs, nullement de notre intention de vouloir entraîner la Porte dans une guerre éventuelle contre les puissances étrangères et qu'en lui demandant, le cas échéant, de fermer les Dardanelles, nous ne prétendions pas la forcer à rompre ses relations de paix et de commerce avec ces mêmes puissances, dont les vaisseaux de guerre seuls ne pourraient être admis dans le détroit. Le motif secret qui guidait les ministres ottomans n'était que le désir d'affaiblir l'engagement relatif aux Dardanelles ou la crainte que la Russie, prévoyant l'explosion d'une guerre générale, n'insistât aujourd'huí sur ce point, par mesure de précaution et pour se préserver de toute agression du côté de la mer Noire.' (Goriainow, p. 41.)

(l) Cambridge Modern History, vol. x. (1907), p. 555.

$\mathbf{P}$. 
phrase profoundly differentiates the present treaty from the Treaty of Constantinople, $1809(\mathrm{~m})$ (with Great Britain), which proclaimed 'the ancient rule of the Ottoman Empire,' and declared that the right of passage would not be granted to the military flag of any Power whatever; whereas now the right of passage was to be granted to Russia alone, when she needed it-' au besoin.' Under the treaty of 1809 the British fleets would not have been able to proceed against the Black Sea coast of Russia if Turkey remained neutral or was allied to Russia. Nor could the Russian Black Sea fleet have emerged into the Mediterranean if Turkey remained neutral or was allied to Russia's enemy. But under the Treaty of Unkiar-Skelessi, if, for example, war broke out between Great Britain and Russia, the Tsar was entitled to call upon the Sultan to exclude the British fleet from the Straits and permit the passage of his own fleet. In other words the Straits became, so to speak, a draw-bridge which the Sultan was obliged to raise at the bidding of the Tsar. A further point is to be noted. The treaty does not explicitly mention the right of Russian warships to pass the Straits from the side of the Mediterranean. But this right was no doubt implied. Moreover, Art. II. expressly renewed previous RussoTurkish treaties, including that of 1805; and by Art. VII. of the latter the Porte was bound to give Russian warships every facility to pass the Straits.

It seemed that the treaty of 1833 gave Russia such advantages in regard to her co-signatory as to make virtually the Black Sea a Russian lake, to put the Ottoman capital at the mercy of the Tsar, and, indeed, almost to establish a protectorate over Turkey. As one of the leading statesmen of the time observes: 'Ainsi le cabinet de St. Pétersbourg, convertissant en droit écrit le fait

(m) See supra, p. 43. 
de sa prépondérance à Constantinople, faisait de la Turquie son client officiel, et de la mer Noire un lac russe, dont le client gardait l'entrée contre les ennemis possibles de la Russie, sans que rien la gênât elle-même pour en sortir et lancer dans la Méditerranée ses vaisseaux et ses soldats' $(n)$.

The conclusion of the Treaty of Unkiar-Skelessi aroused Protests the fears of the western Powers (o). England and France against the made formal protests in notes couched in similar language. The following is the British protest delivered to the Porte (August 26, 1833): 'The undersigned has been instructed to express to the Sublime Porte the deep concern with which the British Government has learnt the conclusion of the treaty of the 8th of July between the Emperor of Russia and the Sultan. That treaty

(n) F. P. G. Guizot, Mémoires pour servir d l'histoire de mon temps (Paris, 1858), vol. iv. p. 49. A Russian writer, commenting in 1878 on this observation of Guizot, asks against whom and for what conquests could Russia, under the treaty, send her fleet and her army : 'Contre qui ? à la conquête de quoi ? demanderions-nous à l'illustre homme d'Etat. En vérité faut-il de la passion, sinon l'aberration politique, oserions-nous dire, pour que, en vue de Gibraltar, de Malte, et aujourd'hui de l'isthme de Suez, le ministre d'une puissance dont tant et de si grands intérêts sont concentrés dans le bassin de la Méditerranée, et dont les forces navales sont coupées par une distance comme celle qui se mesure de Brest à Toulon, pour qu'un ministre français appréhende dans cette mer la présence d'un pavillon qui, au jour donné, pourrait bien être un allié utile, indispensable, mais que ses intérêts mêmes, comme les convenances stratégiques de la Russie ne sauraient jamais y faire entrer comme ennemi ni de la France, ni de l'Italie, ni de l'Autriche." He adds that the treaty does not contain a single word giving Russia the right to profit thereby by sending her ships and soldiers into the Mediterranean, and that the alarm of the western cabinets, and the arbitrary deductions drawn, were not justified. (B. Nekludow, Bosphore et Dardanelles. Étude sur la question des Détroits, Paris, 1878 , pp. 9, 10.) This comment is extremely naïve. The writer appears to imagine, on the one hand, that because a treaty does not expressly specify a certain thing it is therefore necessarily excluded; and, on the other, that danger from this or that quarter becomes impossible if there exists a strong enough power to cope with it. It is to such danger, and therefore possible conflict, that Guizot obviously refers. That the party causing the danger would eventually be overcome by others is another question.

(o) As to the anxiety produced in English official circles, see Lord Palmerston's letter to Lord Ponsonby: Sir H. Lytton Bulwer, Iife of Palmerston (London, 1870), vol. ii. p. 247. 
appears to His Majesty's Government to produce a change in the relations between Turkey and Russia, to which other European States are entitled to object; and the undersigned is instructed to declare that if the stipulations of that treaty should hereafter lead to the armed interference of Russia in the internal affairs of Turkey, the British Government will hold itself at liberty to act upon such an occasion, in any manner which the circumstances of the moment may appear to require, equally as if the treaty above mentioned were not in existence.'

When the Russian Baltic fleet was permitted to pass the Straits after an Anglo-French squadron had made a demonstration at Tenedos without being allowed to enter them, Lord Palmerston observed to Mavrojeni, the Turkish minister in London, that as Russian warships had been granted access to the Dardanelles, those of Great Britain claimed the same right in virtue of the Anglo-Turkish treaty of 1809.

Grounds of of the protests.
The British and French objections to the treaty of 1833 were not based on legal grounds; they depended solely on political considerations. Juridically, the Porte was entitled to make to any other State what concessions it thought fit; it could restrict its sovereignty to any extent in favour of another Power, so long as the privileges thus accorded did not involve an infraction of its obligations to others under existing treaties, or of its obligations under international law and usage in general. But the absence of a legal cause for complaint does not necessarily imply the non-existence of a valid political ground for making a diplomatic protest. Very frequently, indeed, a diplomatic protest founded on political considerations is made for the very purpose of obviating an act or acts that might subsequently be done by this or that State in violation of existing law. Thus in inter- 
national relationships political considerations are very often closely allied to juridical.

Protests and threats notwithstanding, Russia soon applied herself to guard with jealous vigilance the privileges she acquired by the treaty. Thus in 1835 an American frigate reached Constantinople and sought permission to enter the Black Sea. The Porte having submitted the request to Boutenieff, the Russian ambassador, the latter advised a refusal, in order that the other Powers might not seize on a pretext for similarly demanding authorisation to pass the Straits. 


\section{CHAPTER IV.}

THE CONVENTION OF LONDON, 1840, AND THE STRAITS CONVENTION, 1841.

Rivalry between Great Britain the East.
Ат the time of the conclusion of the Treaty of UnkiarSkelessi it was becoming increasingly manifest that Great Britain and Russia were keen rivals in the further East; and it was feared that differences might arise between them more serious and more difficult to solve than those relating to Turkey and the Straits. Friendship between the two Empires was therefore deemed to be indispensable, so that impending problems might be settled by pacific means. Even Palmerston realised the necessity of establishing amicable relationships, as an essential condition for securing peace in Asia. But the distrust aroused in England by the Russo-Turkish alliance of 1833 was an obstacle to a rapprochement. Hopes for the attainment of this object were raised at the end of 1834 when Peel's Tory Government came into power; though Wellington, Foreign Secretary in the newlyformed Cabinet, who was a persona grata at St. Petersburg, and was strongly in favour of a Russian alliance, was of the opinion that the treaty of 1833 would make friendship impossible. This view had some weight with the Russian Government, which none the less refused to abrogate the treaty, although it was not unwilling to have it shelved for the time being among the Russian archives 'as an interesting and honourable historical relic' $(a)$. Diffidence in this country was increased

(a) F. de Martens, Recueil des traités et conventions conclus par la Russie (St. Pótersbourg), vol. xii. (1898) p. 58. 
through the reports of Lord Ponsonby that Russia and Austria had secretly agreed to effect a partition of the Ottoman dominions.

In the meantime, however, Nesselrode and Metternich had signed the secret Convention of Münchengrätz $(b)$ Convention of München(September 6/18, 1833) —of the terms of which Ponsonby was not then aware-whereby the contracting parties engaged to combine their efforts for the maintenance ofthe Turkish Empire in case it was threatened with dissolution through the designs of any political combination; and should their efforts to prevent dissolution fail, they bound themselves to act in accord in everything concerning the establishment of the now order of things: This formal avowal of Russia's policy in regard to the Near East paved the way to an Anglo-Russian understanding.

As for the actual relationships between Russia and Turkey, it was soon found that the difficulties between the two Empires had by no means been effectively Difficulties of the RussoTurkish smoothed over by the alliance of 1833 . The provisions stipulated in it were performed by both parties 'à contrecœur,' for ' they were not in harmony with the historic development of the two States' $(c)$. It was only the impending doom of Turkey, brought about by Mehemet Ali's rebellion and his son's victories, that compelled the Sultan to appeal to the Tsar for help, after calling in vain on the other Powers;-'a drowning man,' said the Seraskier-Pasha, 'clings to a serpent'; and it was through the Tsar's successful interposition that the alliance was established. The Sultan had expected that by making this alliance he would be enabled, with Russia's substantial assistance, to subjugate the rebel vassal, avenge his insurrection, and regain the territories

(b) Ibid. vol. iv. part 1, pp. 445 seq.

(c) Goriainow, p. 52. alliance. 
he had thereby acquired. But soon he came to the conclusion that the Tsar did not intend to aid him in this enterprise, especially so when the Russian Ambassador at Constantinople advocated a policy of moderation in regard to the Egyptian Pasha. This disappointment, added to the untiring efforts of the British and French embassies directed against the menacing influence of Russia at Constantinople, impaired the alliance.

War with Mehemet Ali,

Nor was the ambition of Mehemet satisfied by the 1839. Convention of Kiutayeh, to which he had agreed under European intervention. A renewed conflict between him and Mahmud was therefore inevitable. In 1839 the latter thought the moment for striking had come. On April 21 a Turkish army crossed the Euphrates, and invaded Syria. Disasters again awaited the Turks. On June 24 Ibrahim completely defeated them at Nezib, and once more prepared to march on Constantinople. On June 30 Mahmud died, and was succeeded by his son Abd-ul-Mejid, a lad of sixteen. Immediately afterwards the Capudan Pasha Ahmed proceeded to Alexandria, and, on the pretext that the Ottoman Ministers were sold to Russia, surrendered the Turkish fleet to Mehemet Ali.

Intervention of the Powers.

In this crisis the Powers combined to intervene in order to prevent Russia from interfering alone under the Treaty of Unkiar-Skelessi. Palmerston was determined that if the Russian fleet entered the Straits the British fleet should be allowed to do the same. A proposal made by him and Metternich, that a conference should be held in Vienna for the purpose of arranging a naval expedition to the Dardanelles and for establishing a collective guarantee ensuring the integrity and independence of Turkey, was declined by Russia, who declared her intention to adhere strictly to the provisions of the Treaty of Miinchengrätz. She feared that the 
contemplated combination, ostensibly in favour of Turkey, was in reality to be directed against herself. However, in order to gain time, the ambassadors of Great Britain, France, Russia, Prussia, and Austria presented (July 27, 1839) a joint note to the Porte to this effect: 'The undersigned have this morning received from their respective Governments instructions, in virtue of which they have the honour to inform the Sublime Porte that an agreement on the Eastern Question has been reached between the Five Great Powers, and to urge it to suspend all definite decision made without their concurrence, pending the effect of their interest in its welfare' $(d)$. Despite this joint action the Powers had not yet reached unanimity as to the ultimate settlement; the difference between Great Britain and France was particularly marked.

The opportunity afforded by this divergence of opinion The Tsar's was seized by the Tsar, who was suspicious of Metternich, declarations and so was desirous of withdrawing the British cabinet $\begin{gathered}\text { and the } \\ \text { Straits. }\end{gathered}$ from his influence. Baron Brunnow was accordingly sent to London for this purpose. In his first interview with Lord Palmerston he suggested that measures of coercion against Mehemet Ali should be taken by England and Russia together, and that the closure of the Straits should be established as a definite principle of European public law. He then went on to explain the aim of Russia in concluding the Treaty of UnkiarSkelessi. 'You are mistaken,' he observed, 'if you believed that the Emperor wishes to keep open for himself a door which he is anxious to close against you. I go further. If you consent to recognise and sanction formally the principle I have just suggested, I am prepared to declare to you that His Majesty will allow the Treaty of Unkiar-Skelessi to lapse. You have throughout mis-

(d) British and Foreign State Papers, vol. xxviii. p. 408. 
understood this transaction. The Emperor by no means concluded it in the exclusive interests of Russia. His Majesty signed it because he regarded it as a measure of security for the Porte. This idea of preservation has been misinterpreted in your country. You imagined that the Emperor wanted to arrogate to himself an absolute protectorate over the Ottoman Empire, not to maintain it but imperceptibly to overthrow and destroy it. Hence your distrust of us, hence your unjust prepossessions. His Majesty has decided not to renew the treaty, if we succeed in coming to an agreement as to the means necessary to assure for the future the existence and tranquillity of the Ottoman Empire' $(e)$. Palmerston, in reply, said that the objection of England was not to the permanent closing of the Straits to foreign warships, but to the fact that the treaty procured for Russia the right of exclusive intervention in Turkish affairs.

Later the Russian ambassador proposed that a coalition of the Great Powers should be set up-for political reasons including France (who favoured Mehemet Ali), though the Tsar personally preferred to exclude herfor the settlement of the Turco-Egyptian question $(f)$. Owing, however, to the dilatory tactics of the French Government, due, as was soon discovered, to its secret negotiations with the Sublime Porte $(g)$, the four Powers, without the knowledge of the French ambassador, conTreaty of cluded with Turkey the Treaty of London $(h)$ (July 15, 1840), whereby they engaged to protect the Sultan

(e) Goriainow, p. 67. Cf. F. de Martens, Traités conclus par la Russie, vol. xii. pp. 110 seq.

(f) F. de Martens, ibid. p. 112. Cf. Palmerston to Bulwer, September 24, 1839 : Bulwer, Life of Palmerston, vol. ii. p. 299.

(g) Cf. Guizot, Mémoires, vol. v. pp. 64, 210, 229.

(h) Noradounghian, vol. ii. pp. 303 seq.; Hertslet, Map of Europo, vol. ji. p. 1008 . 
against Mehemet Ali, provided for the exceptional entrance of the Straits in defence of Constantinople, and agreed to respect the 'ancient rule of the Ottoman Empire' relative to the closing of the Straits to every military flag so long as the Porte was at peace. The following Articles are of special importance for our subject:-

'ART. III. If Mehemet Ali, after having refused to submit to the conditions of the arrangements above mentioned, should direct his land or sea forces against Constantinople, the high contracting parties, upon the express demand of the Sultan, addressed to their representatives at Constantinople, agree, in such case, to comply with the request of that sovereign, and to provide for the defence of his throne by means of a cooperation agreed upon by mutual consent, for the purpose of placing the two Straits of the Bosphorus and Dardanelles, as well as the capital of the Ottoman Empire, in security against all aggression.

It is further agreed that the forces which, in virtue of such concert may be sent as aforesaid, shall there remain so employed as long as their presence shall be required by the Sultan; and when His Highness shall deem their presence no longer necessary, the said forces shall simultaneously withdraw, and shall return to the Black Sea and to the Mediterranean respectively.

ART. IV. It is, however; expressly understood that The 'ancient the co-operation mentioned in the preceding Article, and rule of the destined to place the Straits of the Dardanelles and of Empire' to be the Bosphorus, and the Ottoman capital under the temporary safeguard of the high contracting parties against all aggression of Mehemet Ali, shall be considered only as a measure of exception adopted at the express demand of the Sultan, and solely for his defence in the single case above mentioned; but it is agreed, that such measure 
shall not derogate in any degree from the ancient rule of the Ottoman Empire, in virtue of which it has in all times been prohibited for ships of war of foreign Powers to enter the Straits of the Dardanelles and of the Bosphorus. And the Sultan; on the one hand, hereby declares that excepting the contingency above mentioned, it is his firm resolution to maintain in future this principle invariably established as the ancient rule of his Empire, and as long as the Porte is at peace, to admit no foreign ships of war into the Straits of the Bosphorus and of the Dardanelles; on the other hand, their Majesties the Queen of the United Kingdom of Great Britain and Ireland, the Emperor of Austria, King of Hungary and Bohemia, the King of Prussia, and the Emperor of all the Russias, engage to respect this determination of the Sultan, and to conform to the above mentioned principle.'

Passage of light versels.

In a Protocol of the same date the Ottoman plenipotentiary made the following declaration as to the use of the Straits by foreign light vessels:-

'That in recording by Art. IV. of the said Convention the ancient rule of the Ottoman Empire, by virtue of which it has been at all times forbidden to foreign vessels of war to enter within the Straits of the Dardanelles and of the Bosphorus, the Sublime Porte reserves to itself, as heretofore, to deliver passes to light vessels under flag of war, which may be employed according to custom for the service of the correspondence of the legations of friendly Powers.'

Furthermore, by a Protocol signed in London, September 17, 1840, the allied Powers, in order to show their disinterestedness in concluding the Treaty of London, made the following formal declaration:-

' That in the execution of the engagements resulting to the contracting Powers from the above-mentioned 
Convention, those Powers will seek no augmentation of territory, no exclusive influence, no commercial advantage for their subjects, which those of every other nation may not easily obtain.'

By this convention the considerable advantages which Results of the Russia had derived from the Treaty of Unkiar-Skelessi London. were cancelled. The Tsar would undoubtedly have hesitated to enter into such a transaction had he not been at the time animated with hatred for the July monarchy. However this may be, with the treaty of 1840 begins the evolution of the rule of the Straits, on its legal side. Hitherto it had been an 'ancient rule of Effect on tho the Ottoman Empire,' so formulated by the Sultan to- 'ancient rule wards the end of the eighteenth century as a principle Ottoman of Turkish public administration; and from time to time exceptions thereto were made by treaties with foreign States, notably Russia and England. But these treaties bound only the two contracting parties, that is, the Ottoman Porte on the one side, and its co-signatory on the other; third States were not obliged to take cognisance of the existence of such engagements. Moreover, the restriction imposed on the liberty of the Porte in its engagement towards its co-signatory was specifically narrowed down in view of some particular contingency; thus the treaty of 1833 with Russia bound Turkey to close the Straits to third Powers only in the event of Russia being liable to attack. Now, however, a step further is taken in that four of the leading Powers of Europe jointly recognise in a formal international instrument the applicability of the rule of closing the Bosphorus and the Dardanelles to warships of all States, whilst the Sultan, engaging to observe this rule in general, formally surrenders his former right of opening the Straits at discretion.

Next, the Turco-Egyptian question having been The Straits: 
Convention, settled, and France having been conciliated, a still 1841. further step was taken by extending the recognition of the rule and at the same time widening, and so reinforcing, the obligation of the Porte. For the Convention of London-frequently designated the Straits Convention - which was established on July 13, 1841, included the signatures not only of the Powers that had signed the treaty of the previous year, but also the signature of France. Considering its great importance in the legal evolution of the Straits Question, it has been aptly described as 'la charte juridique de la question des Détroits' $(i)$. Its provisions are briefly expressed, thus :-

Closing of Straits to foreign warships in time of peace.
'ART. I. His Highness the Sultan, on the one part, declares that he is firmly resolved to maintain for the future the principle invariably established as the ancient rule of his Empire, and in virtue of which it has in all times been prohibited for the ships of war of foreign Powers to enter the Straits of the Dardanelles and of the Bosphorus; and that, so long as the Porte is at peace, His Highness will admit no foreign ships of war into the said Straits.

And their Majesties the Queen of the United Kingdom of Great Britain and Ireland, the Emperor of Austria, King of Hungary and Bohemia, the King of the French, the King of Prussia, and the Emperor of All the Russias, on the other part, engage to respect this determination of the Sultan, and to conform themselves to the principle above declared.

ART. II. It is understood that in recording the inviolability of the ancient rule of the Ottoman Empire mentioned in the preceding Article, the Sultan reserves to himself, as in past times, to deliver firmans of passage to light vessels under flag of war, which shall be

(i) R. Pinon, in Revue des deux Mondes, October, 1905, p. 812. 
employed as is usual in the service of the missions of foreign Powers.

ART. III. His Highness the Sultan reserves to himself to communicate the present Convention to all the Powers with whom the Sublime Porte is in relations of friendship, inviting them to accede thereto.'

In accordance with Art. III. accessions of other Powers A rule of followed $(k)$; so that the rule becoming general became international at the same time a rule of European international law. The fact that it necessarily implied a diminution of Turkish sovereignty over the Straits could not impair its juridical validity.

The Sultan protested against such interpretation of The Sultan's the treaty as compromised his sovereignty; but his pro- $\begin{gathered}\text { sovereignected. } \\ \text { affect }\end{gathered}$ test could not do away with an obvious fact. It is true that the preamble speaks of the respect which the parties entertain 'for the inviolability of his sovereign rights'; but the very first Article, fastening on the basis of the transaction, requires him to keep his Straits closed to all foreign warships, and so binds him definitively, indeterminately, and generally. The latter part of the Article, recording that the Powers will observe the Sultan's determination to enforce the principle of closing, is manifestly nothing more than a politic formula intended to gloss over the voluntary surrender of his discretionary power. This is clearly confirmed by the very next Article, which, by way of exception, authorises him to continue his old practice of delivering firmans for the passage of light vessels belonging to the various legations in the Ottoman capital; that is, he may still grant firmans to such vessels, but is forbidden to grant them to other kinds of warships.

As the Sultan bound himself towards several Powers, A joint it is clear that if he violated his obligation in favour of convention.

(k) Noradounghian, vol. ii. pp. 345 seq. 
one of them he would be responsible to the others; indeed, he would be responsible to them both individually and collectively. Conversely, the obligation of the Powers is not merely several but joint, as is indicated, in the first place, by the expressions used in the preamble, which speaks of the action of the Powers as being 'in common,' taken by a 'unanimous determination,' and, in the second place, by the drafting of Art. I., which specifies the parties to the engagement as consisting of the Sultan 'on the one part,' and the sovereigns of the five Powers ' on the other part.' This indivisible and solidary obligation assumed by the Powers in the Straits Convention of 1841 is not found in the Treaty of London of the preceding year. 


\section{CHAPTER V. \\ THE TREATY OF PARIS, 1856.}

The Straits Convention of 1841 destroyed the pre- The Straite ponderating influence of Russia in Turkey. She had conventio long striven to acquire it at a great expenditure of blood policy of and treasure, and now was compelled to surrender it abruptly. Acquiescence was found very difficult. In her numerous conflicts with other Powers, Russia has sometimes won and sometimes lost. But whenever she lost, she immediately set to work to recover what she had to abandon. No sooner, then, was the treaty of 1841 signed and ratified, than Nicholas addressed himself to the task of regaining his former position in the near East,--and this, despite the fact that when the treaty was concluded Baron Brunnow, in a communication to Nesselrode, expressed his satisfaction with the result, and thought the principle of closing an advantage to Russia in that her Black Sea coasts were thereby secured from attack $(a)$.

In these circumstances Great Britain, France, and Turkish Austria could not help regarding the Russian Govern- sath regards ment with suspicion and distrust. Turkey, too, remained vigilant. Thus in 1844 and 1847, the Porte made regulations $(b)$ prohibiting vessels from entering the Straits in the night. From sunset to sunrise foreign merchant ships were to be treated as warships. By way

(a) Cf. F. de Martens, Traités conclus pur la Russie, vol. xii. pp. 154, 155.

(b) See Parliamentary Papers. Turkey. No. 16 (1878): Treaties and other Documents relating to the Black Sea, the Dardanelles, and the Bosphorus, 1535-1877; pp. 22, 23. 
of exception, those approaching from the Black Sea were permitted in bad weather to proceed as far as BuyukLiman; and on the following morning, at daybreak, a Turkish officer was charged to ascertain whether or not the state of the sea really justified such action. This regulation was obviously directed against Russia; the disguise of vessels of war was so much easier by night. In February, 1847, another rule was made, which applied equally to warships and to merchantmen in all Ottoman ports. On the arrival of any vessel, the officer of the port was required to go on board and determine the character of the cargo and the number of the passengers and crew. This is a striking departure from the provisions of the Treaty of Adrianople, 1829, which, as we havé seen, bestowed on all Russian vessels immunity from search and other interference $(c)$.

Nicholas? view of 'surkey as a
Nicholas was now emphatically of the opinion that Turkey was a sick man whose demise was imminent, so that it was necessary, in such eventuality, to safeguard his country's interests. He was desirous of an alliance with England. In June, 1844, he came on a visit to London. In his conversations with Prince Albert and the British ministers, he declared that his aim in regard to Turkish affairs was to preserve the status quo. This declaration of policy was soon afterwards repeated-but with a significant modification-by Count Nesselrode in his memorandum to Lord Aberdeen $(d)$. The Russian minister there said that the life of Turkey should be preserved, but suggested that in the event of her destruction the two Powers should come to an understanding as to the establishment of the new order of things. The latter suggestion aroused suspicion, which

(c) Seo supra, p. 51.

(d) Parliamentary Papers, 1854, vol. Ixxi. pt. vi. 
was accentuated by recollections of Tilsit and Akkerman and, above all, Unkiar-Skelessi.

A pretext for Russian intervention in Turkey pre- The Holy sented itself in 1850, when Russia found herself in conflict with France on the question of the Holy Places. Under the capitulation of 1740 Louis XV. acquired, among other privileges, the right to the custody of the Sacred Places in Jerusalem; but, thanks to the rationalistic and revolutionary movements, France soon neglected the charge she had eagerly sought. On the other hand, the Greek clergy at Jerusalem, being under the protection of Russia, assumed functions and took over rights and property that were thought to belong to France. In 1850 , the ultramontane reaction being at its height, Napoleon was anxious, as President of the French Republic, to win Roman Catholic sympathies; and accordingly he demanded of the Porte the restitution of French rights. The efforts of the Ottoman Government to satisfy the contending parties failed. The conflict was then aggravated by the proclamation of the Empire (December 2, 1852). Napoleon's title as sovereign was recognized by nearly all foreign States; but Nicholas, imbued with legitimist traditions, denied the dynastic claims implied in his formal designation. The breach thus grew wider; and it soon became evident that the seemingly trivial dispute between the two Powers became a contest for supremacy in the Near East. Turkey was perplexed. Great Britain coùnselled moderation. Napoleon showed a warlike determination. Russia, relying on the support of Austria and Prussia, was not unwilling to go to war, whereby she thought the Eastern Question might be settled once for all.

To gain English sympathy was now the main task of Partition Nicholas. In January, 1853, he had an interview with $\begin{gathered}\text { seheme of } \\ \text { Nicholas, }\end{gathered}$ Sir Hamilton Seymour, the British ambassador in St. 
Petersburg; as in 1844, he spoke again of the 'sick man,' and of the necessity to make arrangements for the inheritance, and outlined a partition scheme, according to which neither of the parties was to acquire permanent possession of Constantinople (e). Lord John Russell, however, did not accept the view as to Turkey's impending dissolution, and held that difficulties with the Ottoman Government should be settled only by the combined action of the Powers. Immediately afterwards the Russian ministers tried to undo the effect created by the Tsar's confidences, but the old suspicion and distrust had already been awakened and could not so easily be removed.

Mission of Menshikoff, 1853.
In the meantime Nicholas sent Prince Alexander Menshikoff on a special mission to Turkey (February, 180̃3), to lay before the Sultan his master's final demands-viz., to maintain the status quo in regard to the Holy Places, and to secure definitive recognition (in accordance with the Treaty of Kutchuk-Kainardji) of Russia's right to protect all members of the Greek Church dwelling within the Ottoman Empire. A convention to this effect was demanded by the envoy (April 19). In principle the claim was not unreasonable; it was in accord with the protection acquired by the treaty of 1774 ; moreover, such rights in regard to the Greek Church were asked for as were already being exercised by Austria in the case of the Roman Catholic Church. But the members of the latter were few in Turkey, those of the former were numerous; so that Russian protection might well lead to ubiquitous intervention. Accordingly the Porte, alienated already by Menshikoff's overbearing attitude, and encouraged by the counsels of the British and French ambassadors,

(e) Cf. Parliamentary Papers, vol. 1xxi. pt. v. 1 ; F. de Martens, Traités conclus par la Russie, vol. xii. pp. 306 seq. 
Lord Stratford de Redcliffe and Count Benedetti, refused the demands. A Russian ultimatum was then presented and rejected (May 5), the Russian ambassador left Constantinople, and the troops of the Tsar soon invaded Moldavia (July 3, 1853).

Great excitement was aroused in England. Anglo- Occupation of French squadrons were despatched to the Sea of Mar- Principalities. mara. This proceeding, Russia thought, was an infringement of the Straits Convention of 1841, whilst The Straits her own occupation of the Danubian Principalities was in question. only a measure of coercion $(f)$. On the other hand, Great Britain and France contended that their step was justified, inasmuch as they were bound by the treaty to defend the integrity of the Ottoman dominions. Russia denied that an engagement was thereby established amounting to a guarantee. Baron Brunnow, replying to inquiries made by Lord Aberdeen, observed that during the negotiations for the treaty of 1841 the Austrian plenipotentiary suggested the insertion of a special clause of guarantee, but that he (Brunnow), supported by Lord Palmerston, opposed it, whereupon it was abandoned. The preamble of the treaty, he maintained, expresses the desire of the Powers to maintain the integrity of Turkey, but does not on that account contract an obligation to do so ; it is not an engagement in strict law, but is merely the preface to a stipulation relating exclusively to the closing of the Straits in time of peace $(g)$. Similarly M. Goriainow concludes: 'Ainsi, dans cette déclaration solennelle il n'y a pas d'obligation formelle; ce ne sont que des considérations, un ensemble des raisonnements qui ont conduit à la conclusion de l'acte' $(h)$. And he holds that Russia, in occupying the

(f) Cf. Goriainow, p. 93.

(g) Ibid. p. 93.

(h) Ibid. p. 94. 
Danubian Principalities, violated no formal obligation; whilst the action of England and France was contrary to the Straits Convention, seeing that when their warships passed the Dardanelles (June, 1853) peace still existed-the declaration of war between Russia and Turkey having been made only on October 4, 1853.

The Russian view untenable.

Allied fleets enter the Black Sea, 1854.
Some little weight may be given to this argument if we take only a superficial view of the treaty and apply a purely literal interpretation to its provisions. But having regard to the very object of its conclusion, and the spirit of the engagement, the argument fails. The Anglo-French proceedings were justified juridicallycertainly politically. England and France were parties to an international instrument, whose entire raison d'être was due to a common determination and a common agreement to preserve the territorial integrity of the Turkish Empire. The Russian invasion of the Danubian provinces-whatever was its ostensible purpose-was a serious menace to this integrity, if not the initial stage of its destruction. At all events it was a violation of Turkish territory, and gave the Porte a valid ground for war. The other signatories were consequently entitled to take adequate measures to protect Turkey in fulfilment of their undertaking; they were not obliged to wait until the process of destruction had gone apace.

As the Russian army continued its advance, the allied fleets entered the Bosphorus (October 22, 1853); and after the destruction of a Turkish squadron at Sinope, they, at the request of the Sultan, entered the Black Sea (January 3, 1854)(i)-an act constituting a casus belli in the eyes of Russia. In reply to protests from the Russian Government, England and France entered

(i) Cf. E. Ashley, Life and Correspondence of Henry John Temple, $V$ iscount Palmerston (London, 1879), vol. ii. chap. 2 ; Parliamentary Papers, vol. lxxi. pt. 2, No. 337. 
into an alliance, then concluded the Treaty of Constantinople with Turkey (March 12, 1854), which gave them full powers to act, and afterwards formally declared war on Russia (March 27). The latter treaty authorised the entrance of the allied fleets in the Black Sea; for, under the Straits Convention, the Sultan might permit foreign warships to pass the Straits as soon as he became engaged in hostilities.

The treaty of 1841 was concluded with the object of The Straits restoring European equilibrium, which had been dan- and the I gerously disturbed by the Treaty of Unkiar-Skelessi. It was then felt that peace would be thereby ensured in Europe. On the contrary, as it happened, the Straits Convention was the principal link in the chain of cause and effect that led to the Crimean War. As a French historian says: 'La guerre de Crimée était en germe dans la Convention des Détroits' $(j)$.

In the peace negotiations the allied Powers laid down The 'four the fundamental conditions demanded by them in the form of 'four points'; these related to the abolition of the Russian protectorate over the Danubian principalities, the free navigation of the Danube, the neutralisation of the Black Sea, the position of Christian subjects of Turkey. There was little difficulty in coming to an understanding on the first two points; the third, involving a revision of the treaty of 1841 -which, therefore, concerns us here most of all-presented the toughest problem.

At the meeting of the representatives held on Memorandum December 28, 1854, Baron de Bourqueney, the French of Bourqueambassador to Austria, presented a memorandum, which 1854 . he had prepared along with Lord Westmoreland, the British ambassador to Austria, and Count Buol, the

(j) A. Debidour, in E. Lavisse et A. Rambaud, Histoire générale (Paris), vol. x. (1898), p. 941. 
Austrian Minister for Foreign Affairs, wherein it was said that the object of the revision of the treaty of 1841 should be to associate more completely 'the existence of the Ottoman Empire to the European equilibrium and to put an end to the preponderance of Russia in the Black Sea' $(k)$. Prince Gortchakoff accepted the principle of associating Turkey to the European equilibrium, but opposed the suggestion as to putting an end to Russian preponderance in the Black Sea; to which Baron Bourqueney replied that it was not the intention of any of the three Powers to propose measures derogatory to the dignity and honour of the Tsar or his rights of sovereignty.

Interview between Francis

Joseph and

Gortchakoff Jan. 1855 .

On January 2, 1855, Prince Gortchakoff had an audience of Emperor Francis Joseph, who declared that he would never be a party to any act affecting the Tsar's honour or dignity. Relying on this assurance, Gortchakoff consented to go into the question of adjusting the Russian position in the Black Sea, on the grounds thus specified in a despatch of December 22/January 3 : 'Il existe deux moyens de diminuer la prépondérance d'un état: ou de l'affaiblir ou de fortifier la puissance qui en est menacée, soit en augmentant ses propres forces, soit en admettant des contrepoids auxquels elle aurait consenti elle-même. La ferme résolution de notre auguste maître et les déclarations positives, que m'a faites l'empereur François-Joseph, écartent toute possibilité de diminuer notre prépondérance dans la mer Noire par un affaiblissement direct de la Russie, ou par des prétentions qui atteindraient l'exercice de la souveraineté de la Russie. Quant à l'autre moyen, il est probable que les deux cours occidentales chercheront à obtenir sur territoire turc des établissements pour leurs

(k) Goriainow, p. 97 ; British and Foreign State Papers, vol. xlv. (1854-1855), pp. 53 seq. 
vaisseaux de guerre. Nous ne pourront pas nous y opposer; il suffirait seulement d'exclure Batoum pour des raisons de sécurité, si évidentes que nous pourrons conserver l'espoir d'y rallier même l'Autriche. Ces établissements anglo-français sur la mer Noire seraient provisoires et n'auraient de durée que jusqu'au moment où la Porte elle-même croirait ne plus en avoir besoin, comme garantie de son existence. Ce dernier principe serait d'accord avec les vues du cabinet de Vienne, car ce n'est point dans ses intérêts de voir la présence de flottes anglo-françaises dans la mer Noire' $(l)$. Count Nesselrode's Nesselrode, approving of this view, observed in a com- Straits $\begin{gathered}\text { Convention. } \\ \text {. }\end{gathered}$ munication to Gortchakoff (January 6) in regard to the revision of the treaty of 1841: "The Emperor judges this question with perfect impartiality. He starts from the principle that our transactions concluded directly with the Porte never made the Black Sea a closed sea. The closing of the Straits to the military flag was not then the result of our transactions with the Porte. It was due only to the ancient legislation of the Ottoman Empire. The treaty of 1841 served simply to recognize and confirm this principle, established by the Sultans in their capacity of sovereigns of the territory adjacent to the two Straits. They are free to open the passage, as they were entitled to close it. As long as the Straits remained closed, it followed naturally that the Black Sea was accessible only to the warships of the two littoral Powers, Russia and Turkey. The inferiority of the latter is not a new fact. We do not contest it. Furthermore, the Emperor himself does not object to the Sultan's emerging, if he deems it necessary, from the forced isolation imposed on him by the Black Sea as long as it remains closed. The Emperor is then the first to admit the power that the Sultan possesses, in

(l) Goriainow, pp. 98, 99. 
right and in fact, to open the passage of the Straits to the warships of States with which he is at peace; but reciprocally, in opening the Straits on like terms, to authorise the passage from one sea to the other, and that in favour of all nations. If this principle, adopted in the interest of the general equilibrium, can serve to put an end to the relative inferiority in which the Porte was placed through its isolation, the Emperor will be ready to give spontaneously this fresh pledge of security to the peace of Europe' $(m)$. As M. Goriainow points out, Count Nesselrode, purporting to state the observations of the Tsar that the Russian transactions with Turkey never made of the Black Sea a closed sea, forgot Art. VII. of the treaty of September 11/23, 1805, which says: 'The two high contracting parties have agreed to consider the Black Sea closed, and not to allow any warship to enter therein.' No mention was made of the ' ancient rule of the Ottoman Empire,' a phrase which appeared for the first time in the Treaty of Constantinople, 1809, between Great Britain and Turkey. In the negotiations of 1840 Baron Brunnow was prepared to recognise it as closed, but he submitted to the arguments of Palmerston and Metternich, who held that such a view was not consonant with the provisions of the Treaty of Adrianople, which declared the Black Sea open to the commerce of all nations.

Austrian view as to Black Sea.

In an interview between Count Buol and Prince Gortchakoff, the former suggested that the Tsar should himself relinquish his sovereign rights in the Black Sea and restrict the number of his warships there. The Austrian minister asked what was the object and the task of the Russian large fleet in those waters. Conformably to treaties, he pointed out, the Black Sea was a closed lake, a prison for the Tsar's vessels and yet a (m) Goriainow, pp. 99, 100. 
permanent menace to Turkey, as well as a cause of distrust for Europe. If Russia had no designs against the Ottoman Empire, what was the use of maintaining unemployed forces in those regions? The Emperor was of course entitled to have as many vessels in his ports as he thought fit; but would it not be to his advantage to ensure the passage of a limited number of warships through the Dardanelles, and so maintain communications between Sebastopol and Cronstadt? Such a disposition would remove the fears of Europe, which were always aroused by the agglomeration of large forces in the Black Sea $(n)$. To this argument Gortchakoff replied that that was a question for the Emperor alone; but he add ad that considering the condition of Turkey, her existence could not be prolonged much more by the Powers, so that Russia could not remain unprotected against foreign fleets, nor could she allow Constantinople to fall into the hands of any great European Power.

At the meeting of the Conference of March $27(0)$, Fundamental Count Buol reminded the representatives that they were before the to determine two fundamental questions, first, the maintenance of Turkey in association with the European equilibrium to be provided by modifications of the treaty of 1841 ; secondly, the question of naval forces in the Black Sea. Bourqueney suggested the neutralisation of the Black Sea, but Gortchakoff regarded this proposal as a jest; for to exclude Russian vessels of war therefrom would be derogatory to the honour and dignity of Russia. The Tsar's representative then submitted a counter-proposal, permitting foreign warships to come to the Black Sea, and Russian warships to go to the Mediterranean; he emphasised that liberty of navigation

(n) Ibid. pp. 101, 102.

(o) British and Foreign State Papers, vol. xlv. (1854-1855), pp. 79 seg. 
in the Black Sea would ensure the security of Europe. Lord John Russell then informed Gortchakoff that he was instructed to demand a limitation of the Russian fleet in proportion to that of Turkey, and to obtain a promise from Russia that she would not depart from the status quo.

Limitation of Russian fleet suggested.

At the sitting of April $17(p)$, the Russian plenipotentiary, replying to an observation of Drouyn de Lhuys, the French representative, stated that his Government refused to be a party to an agreement restricting its marine. Drouyn de Lhuys then pointed out (April 19) (q) that as the Black Sea was then occupied only by the fleets of the allied Powers, and the Russian fleet had no existence there at all, it was for Russia, and not for the allies, to ask for concessions. A draft submitted by him was rejected by Gortchakoff (April 21)(r) on the ground that it affected the sovereign rights of the Tsar, that it would be detrimental to European equilibrium, and would endanger the independence of Turkey. He then made a statement, which consisted substantially of Nesselrode's despatch, as given above (s), setting forth the view that the closing of the Straits to the military flag arose solely from the ancient legislation of the Ottoman Empire, and (erroneously) that Russo-Turkish treaties never made the Black Sea a closed sea $(t)$. His counterproposal as to opening (April 22)(u) was not discussed

( $p$ ) British and Foreign State Papers, pp. 87 seq. An English translation of the protocols (including some of the annexes) of March 26, April 17, April 19, April 21, April 26, June 4, 1855 ; February 25, February 28, March 1, March 6, March 12, March 18, March 22, March 26, March 27, 1856, is to be found in Parliamentary Papers, Turkey, No. 16 (1878): Treaties and other Documents relating to the Black Sea, the Dardanelles, and the Bosphorus, 1535-1877, pp. $24-49$.

(q) Ibid. vol. xlv. p. 93.

(r) Ibid. p. 99.

(s) See supra, p. 89.

(t) Annex A to Protocol No. 12, April 21, 1855; British and Foreign State Papers, vol. xlv. (1854-1855), pp. 105-109.

(u) Ibid. pp. 109, 110. 
by the other representatives, on the ground that they were not authorised to consider this question $(x)$. A few days later (April 26) (y) he presented another counterproposal, suggesting that the Straits should be closed in time of peace, and that the Sultan should be free to open them when he found it necessary to do so for his security. The English and French plenipotentiaries, however, insisted on a limitation of the Russian Black Sea fleet $(z)$.

The last meeting of the Conference was held on Negotiations June 4(a), when the Austrian representative proposed. Sunoken of that the number of Russian warships in the Black Sea should not exceed the number then afloat. Again the objection was made that this would affect the sovereignty of Russia. Whereupon Baron Bourqueney and Lord Westmoreland declared that the negotiations were no longer possible, and Count Buol declared the Conference to be closed. M. Goriainow, commenting on the Austrian proposal, observes justly, that the expression, 'l'etat actuel des bâtiments russes à flot dans cette mer,' \&c.(b), had no reasonable significance, seeing that the Black Sea fleet had already been sunk; and he adds: 'Ce n'était qu'un subterfuge honteux et insidieux du ministre d'Autriche' (c).

After the fall of Sebastopol negotiations were resumed, By November 14 the plenipotentiaries of England, France and Austria had definitely agreed upon the 'four Negotiations resumed after fall of Sebastopol. points,' of which one was the neutralisation of the Black Sea. Russia then made another effort to secure an amendment; she brought forward again the principle of closing, and proposed that all vessels of war should
(x) Ibid. p. 112.
(y) Ibid. pp. 111, 117.
(z) Ibid. p. 112.
(a) Ibid. pp. 118 seq.
(b) Ibid. p. 123.
(c) Goriainow, p. 127. 
be excluded from the Black Sea save as agreed to between herself and the Porte. A modification submitted by the other Powers was eventually accepted by the Tsar, after the Austrian ultimatum had been delivered.

Preliminary conditions of peace.

Treaty of Paris, 1856.

Tarkey admitted into the European systom.

Gaarantee of territorial integrity.
The preliminary conditions of peace were signed at Vienna on February 1, 1856; on February 25 the plenipotentiaries assembled at Paris to draw up a definitive treaty of peace $(d)$; and on March 30 the Treaty of Paris was signed $(e)$. Provision is therein made for the evacuation of territories (Art. II.), the mutual restoration of territory (Arts. III., IV.), amnesty (Art. V.), prisoners of war (Art. VI.), the navigation of the Dauube and the establishment of the River Commission (Arts. XV.-XIX.), the rectification of the Russian frontier (Arts. XX., XXI.), the organization of the Principalities (Arts. XXII.-XXIX.), and the Russian and Turkish possessions in Asia (Art. XXX.).

For our present purpose, however, the following stipulations are of the greatest importance:-

' ARt. VII. Her Majesty the Queen of the United Kingdom of Great Britain and Ireland, His Majesty the Emperor of Austria, His Majesty the Emperor of the French, His Majesty the King of Prussia, His Majesty the Emperor of All the Russias, and His Majesty the King of Sardinia, declare the Sublime Porte admitted to participate in the advantages of the public law and system of Europe. Their Majesties engage, each on his part, to respect the independence and the territorial integrity of the Ottoman Empire, guarantee in common the strict observance of that engagement, and will, in

(d) For the protocols, see British and Foreign State Papers, vol. xlvi. pp. 63 seq.

(e) For full text, see Hertslet, Map of Europe, vol. ii. p. 1250 ; given also in C. Phillipson, Termination of $W$ ar and Treaties of Peace (London, 1916), pp. $350-357$. 
consequence, consider any act tending to its violation as a question of general interest.

ART. VIII. If there should arise between the Sublime Mediation Porte and one or more of the other signing Powers, any Turkeen and misunderstanding which might endanger the mainten- any of the ance of their relations, the Sublime Porte, and each of such Powers, before having recourse to the use of force, shall afford the other contracting parties the opportunity of preventing such an extremity by means of their mediation.

ArT. IX. His Imperial Majesty the Sultan having, in $\begin{gathered}\text { Christian } \\ \text { subjects of }\end{gathered}$ his constant solicitude for the welfare of his subjects, the Sultan. issued a firman, which, while ameliorating their condition without distinction of religion or of race, records his generous intentions towards the Christian population of his Empire, and wishing to give a further proof of his sentiments in that respect, has resolved to communicate to the contracting parties the said firman, emanating spontaneously from his sovereign will.

The contracting Powers recognise the high value of this communication. It is clearly understood that it cannot, in any case, give to the said Powers the right to interfere, either collectively or separately, in the relations of His Majesty the Sultan with his subjects, nor in the internal administration of his Empire.

Art. X. The Convention of 13th of July, 1841, which The maintains the ancient rule of the Ottoman Empire rela- and tive to the closing of the Straits of the Bosphorus and of the Dardanelles, has been revised by common consent.

The Act concluded for that purpose, and in conformity with that principle, between the high contracting parties, is and remains annexed to the present treaty, and shall have the same force and validity as if it formed an integral part thereof $(f)$.

(f) See the Straits Convention annexed to the present treaty, p. 97. 
The

Black Sea neutralised.

ART. XI. The Black Sea is neutralised; its waters and its ports, thrown open to the mercantile marine of every nation, are formally and in perpetuity interdicted to the flag of war, either of the Powers possessing its coasts, or of any other Power, with the exceptions mentioned in Arts. XIV. and XIX. of the present treaty.

ARt. XII. Free from any impediment, the commerce in the ports and waters of the Black Sea shall be subject only to regulations of health, customs, and police, framed in a spirit favourable to the development of commercial transactions.

In order to afford to the commercial and maritime interests of every nation the security which is desired, Russia and the Sublime Porte will admit consuls into their ports situated upon the coast of the Black Sea, in conformity with the principles of international law.

ARt. XIII. The Black Sea being neutralised according to the terms of Art. XI., the maintenance or establishment upon its coast of military-maritime arsenals becomes alike unnecessary and purposeless; in consequence, His Majesty the Emperor of All the Russias, and His Imperial Majesty the Sultan, engage not to establish or to maintain upon that coast any military-maritime arsenal.

ARt. XIV. Their Majesties the Emperor of All the Russias and the Sultan having concluded a Convention $(g)$ for the purpose of settling the force and the number of light vessels, necessary for the service of their coasts, which they reserve to themselves to maintain in the Black Sea, that Convention is annexed to the present treaty, and shall have the same force and validity as if it formed an integral part thereof. It cannot be either annulled or modified without the assent of the Powers signing the present treaty.

Straits opened for purposes of evaouation.
Additional and Transitory Article. The stipulations

(g) See infra, p. 98. 
of the Convention respecting the Straits, signed this day, shall not be applicable to the vessels of war employed by the belligerent Powers for the evacuation, by sea, of the territories occupied by their armies; but the said stipulations shall resume their entire effect as soon as the evacuation shall be terminated.'

The Straits Convention referred to in Art. X. was signed on the same date, and is as follows:-

'Arт. I. His Majesty the Sultan, on the one part, $\underset{\text { Straits to }}{\text { Closing }}$ declares that he is firmly resolved to maintain for the warships. future the principle invariably established as the ancient rule of his Empire, and in virtue of which it has, at all times, been prohibited for the ships of war of foreign Powers to enter the Straits of the Dardanelles and of the Bosphorus; and that, so long as the Porte is at peace, His Majesty will admit no foreign ship of war into the said Straits.

And Their Majesties the Queen of the United Kingdom of Great Britain and Ireland, the Emperor of Austria, the Emperor of the French, the King of Prussia, the Emperor of All the Russias, and the King of Sardinia, on the other part, engage to respect this determination of the Sultan, and to conform themselves to the principle above declared.

Art. II. The Sultan reserves to himself, as in past Light vessels. times, to declare firmans of passage for light vessels under flag of war, which shall be employed, as is usual, in the service of the missions of foreign Powers.

ArT. III. The same exception applies to the light vessels under flag of war which each of the contracting Powers is authorised to station at the mouths of the Danube in order to secure the execution of the regulations relative to the liberty of that river, and the number of which is not to exceed two for each Power.'

The Convention between Russia and Turkey (men- Russian and P. 
ships in the tioned in Art. XIV.) for settling the number and force
Black Sea. of light ressels destined for the coast service in the Black Sea is to the following effect :-

'ART. I. The high contracting parties mutually engage not to have in the Black Sea any other vessels of war than those of which the number, the force and the dimensions are hereinafter stipulated.

Art. II. The high contracting parties reserve to themselves each to maintain in that sea six steam-vessels of 50 metres in length at the line of flotation, of a tonnage of 800 tons as the maximum, and four light steam or sailing vessels of a tonnage which shall not exceed 200 tons each.'

Convention between Great Britain, France, and Austria.

The Treaties of Paris as collective engagements.
Finally, on the proposal of Austria, a further conven$\operatorname{tion}(h)$ was signed at Paris on April 15, 1856, between Great Britain, France and Austria, for the purpose of ensuring the independence and integrity of the Ottoman Empire by means of their joint and several guarantee (Art. I.); it was agreed that any infraction of the stipulations of the Treaty of Paris would be considered by the signatories as a casus belli (Art. II.). Russia is not mentioned at all in this Convention, but it is obvious that it was directed against her; for it was the inveterate policy of Great Britain to prevent the Tsar from becoming master of the Straits and so endangering British interests in the East, and it was the object of Austria to prevent the Tsar from occupying the Danubian Principalities.

The Treaty of Paris and the Straits Convention annexed to it are clearly collective engagements $(i)$, and not simply a number of separate agreements made by the Powers with Turkey. There appears to be a discrepancy between Art. XI. of the treaty of peace itself

(h) Hertslet, Map of Europe, vol. ii. p. 1280.

(i) Seo infra, chap. viii. 
and Art. I. of the Straits Convention. The former, by stipulating the neutralisation of the Black Sea, excluded warships therefrom in all cases, that is, whether the Porte was at war or at peace. The latter prohibited the admittance of foreign ships of war into the Straits only whilst the Porte was at peace. Therefore if it was at war with Russia it could allow, say, the fleets of (ireat Britain and France to pass the Dardanelles and the Bosphorus if they wished to proceed to the Black Sea. Of these two interpretations the latter would, of course, prevail in the case of a war between Russia and 'Turkey, when the guaranteeing Powers would take the side of the Sultan. Russia's position after the settlement was, Position of accordingly, a most disadvantageous one. As an $\begin{gathered}\text { Ruscia after } \\ \text { Paris. }\end{gathered}$ eminent Russian jurist observed, the treaty. of 1856 became for the Powers ' une arme contre la Russie; ce fut un moyen de gêner celle-ci au cas où elle se trouverait en guerre avec la Turquie' $(k)$. Before the Russian expansion under Peter the Great and Catherine II. the Black Sea was a Turkish lake. After the Treaty of Unkiar-Skelessi it became virtually a Russian lake. Now, the Treaty of Paris made it a European Sea, and placed it under the express sanction of the Powers. To the existing notions of free sea and territorial sea-mare liberum or apertum, and mare clausum-a new conception was added, viz. that of a neutralised sea; thus the principle of continental neutralisation, adopted in the interests of political equilibrium, was applied to a maritime sphere with the same object $(l)$. A measure of this kind is no doubt a great advantage to the world at large from the point of view of commercial navigation; the exclusion of vessels of war is not necessarily a

(k) F. de Martens, Traité de droit international. Trans. from the Russian (Paris, 1886), vol. ii. p. 359.

(l) Cf. P. Pradier-Fodéré, Traité de droit international public (Paris, 1885, etc.), vol. ii. p. 185. 
violation of the fundamental principle of the freedom of the seas, as such prohibition is really a means of securing it $(m)$; but it is not an unalloyed advantage if such restrictions are thereby imposed on a State as to impair its sovereignty, and interfere with its natural and inalienable right of self-defence. 'Russia was treated as a suspect, isolated as a public peril, excluded from the court-yard of her own house, where, in spite of an illusory neutrality, her enemies could penetrate without any obstacle' $(n)$. No wonder, then, that the entire foreign policy of Alexander II., during the first fifteen years of his reign, aimed at one objectthe removal of this conventional incubus.

(m) Cf. J. C. Bluntschli, Das moderne Völkerrecht (Nördlingen, 1872), $\S 308$.

(n) R. Pinon, in Revue des deux mondes, October, 1905, p. 812. 


\section{CHAPTER VI.}

DENUNCIATION OF THE TREATY OF PARIS-TREATY OF LONDON, 1871.

THe defeat suffered by Russia in the Crimea, the loss of Difficulties her fleet, the surrender of territory, and, above all, the prohibition laid on her regarding the Black Sea, affected her position as a great and growing State so much that the humiliation became increasingly intolerable. For nearly two centuries she had unceasingly struggled, at the cost of enormous sacrifices, to establish herself on the waters of the Euxine, to build a navy and erect fortifications for her protection there; and now she saw the results of her long and arduous labours well-nigh destroyed. An international arrangement that could bring this about was condemned in advance to a brief existence. 'La neutralisation de la mer Noire était une combinaison condamnée par avance à une existence de courte durée. Un puissant empire, doué d'une grande force d'expansion, comme la Russie, ne se laisse pas imposer pendant un long temps des servitudes incompatibles avec sa dignité et avec son indépendance' $(a)$.

The western Powers realised the extremely difficult Her difficult position of Russia, and more than once were prepared to help her, in return for a certain consideration, to position realised by
the Powers. shake off her burden. Thus Napoleon before declaring war on Austria in 1858, sought, with this view, the Tsar's support. In 1859, after the war, Austria similarly approached Russia, and again in 1867 after her

(a) H. Bonfils, Manuel do dront international public (Paris, 1912), $\S 502$. 
defeat by Prussia. But Russia refused then to be embroiled in a European conflict, and hoped that a more suitable opportunity would arrive for withdrawing, if possible in a pacific manner, from her sinister engagement of 1856-an engagement contracted, of course, involuntarily.

Determina tion of the Tsar Alexander.
The single-minded determination of the Emperor Alexander was strikingly manifested in 1863, when Russia was faced with the Polish insurrection. Attending a meeting of his Privy Council, the Tsar opened the proceedings with these words: 'Seven years ago, at this table, I did an act which I know how to describe, since it was I who performed it: I signed the Treaty of Paris, and it was an act of cowardice!' When those present protested, the Emperor, striking the table, repeated his statement: "Yes, it was an act of cowardice, and I will not, indeed, do such a thing again' (b).

Not long afterwards we find Baron Brunnow, the Russian ambassador in London, declaring in a despatch (April 30/May 12, 1866) that whilst the closing of the Straits may have been a political necessity for Russia in 1856 , as the peoples of the littoral were not then subjugated, it had lost its original value in 1866. Moreover, he observed, the Black Sea was neither open nor closed entirely, since each of the signatory Powers had acquired the right of stationing two light vessels at the mouths of the Danube. This led him to believe that Russia would have nothing to lose, if the principle of closing, in time of peace, were formally abrogated. In time of war this principle was, evidently, of no value to her, as the Porte could admit foreign fleets into the Straits, if it thought that the protection of Turkey demanded it. Further, the Russian marine always considered the closing of the sea as a disadvantage in that

(b) Goriainow, p. 147. 
access to the Mediterranean was denied to them. All these considerations must be thoroughly examined before reaching the conclusions that should be set forth, when the revision of the Treaty of Paris was to be taken in hand $(c)$.

The resolve of the Emperor Alexander to abrogate Attitude of the restrictive provisions was for several years known to of Prussia. his uncle, King William of Prussia. The latter, in a communication made in August, 1866, informed the Tsar of his victories over the Austrians, and said that he sent him his aide-de-camp, Lieutenant-General Manteuffel, in order to get his views on the European situation. 'He will receive with eagerness,' remarked King William, 'all the observations you care to make to him. You will tell him frankly if there are any Russian interests the satisfaction of which might strengthen the ties which have united us for a century, during which period the interests of Russia have never been contrary to those of my country.' The Emperor wrote in reply : 'General Manteuffel has conveyed to me your intimate thought. He will inform you of the reflexions it inspired in me. I thank you heartily for this fresh mark of confidence. I have responded with complete frankness. In our frequent conversations he has made himself acquainted with my intimate thought. He will report it to you faithfully' $(d)$. The 'intimate thought' of the Tsar was his intention to liberate himself from the trammels imposed on him by the Treaty of Paris.

The European situation brought about by the Franco- The FrancoPrussian War gave Russia the longed-for opportunity. The latter observed in 1870, as she had done in 1866, a friendly neutrality towards Prussia; and now, France having collapsed and Prussia-well-disposed towards the

(c) Ibid. pp. 145, 146.

(d) Ibid. 
Tsar (e)-having triumphed and become the greatest military Power in the West, Russia thought the moment propitious for launching her long-prepared thunderbolt.

Russo-

Turkish negotiations as to the objectionable Articles of the Treaty of Paris.

In August, 1870, excitement was aroused in England by reports in the press of Vienna and of Buda-Pesth of negotiations between General Ignatieff, the Russian ambassador at Constantinople, and Ali Pasha, the Grand Vizier, concerning the abrogation of the objectionable stipulations of the Treaty of Paris. Ignatieff, in his despatch, said that as the condition of Western Europe was favourable to his country's Eastern interests, he thought it his duty to prepare the minds of Turkish ministers for grasping the aim of Russian policy in this respect, centred, as it was, on a revision of the treaty of 1856. He was convinced that there were only two methods of influencing effectively the minds of Turks; by adopting a brusque and menacing attitude, or by gradually winning them over by persuasive means. The first was then inexpedient, as it would provoke a general conflagration detrimental to Russia; the second was therefore the method to be followed. Accordingly, on every occasion that presented itself he endeavoured to persuade the Ottoman minister that their interests would not be impaired by the modification in question. The grave events in Western Europe gave him an opportunity of renewing the subject, which, however, he discussed with the Grand Vizier ' in a purely academic and personal manner' $(f)$. Ignatieff declared that Russia had no designs with regard to the Ottoman Empire, that she did not wish to destroy the collective guarantee of its integrity, that the injury done to her amour-propre by the Treaty of Paris was the main consideration, that its revision would be advantageous to Turkey, and that an

(e) Cf. Cambridge Modern History, vol. xii. (1910), pp. 138, 139.

(f) Goriainow, pp. 149, 150. 
explosion might occur at any moment. The Sultan could win the friendship of the Tsar only by treating his Orthodox subjects equitably, and abandoning his distrust of Russia. The treaty of 1856 had long ago ceased to have legal validity in the eyes of Russia, on account of the numerous infringements of it committed by the signatory States; but the Chancellor, Prince Gortchakoff, doubted whether the offensive Articles could be duly abrogated in Constantinople.

The Russian Government now sought the definitive Prussian assurances of victorious Prussia. A despatch from of support. Bismarck to Prince Reuss, Prussian minister at St. Petersburg, dated Ferrières, September 20, 1870, declared that King William considered the 'Tsar's intended step to be justifiable; that a treaty excluding the flag of a Power like Russia from a neighbouring sea was contrary to nature and could not be durable; therefore, if Russia, having regard to the breaches of the treaty already committed, no longer regarded herself as bound by it, Prussia would do her utmost to get not only France, but also the other.Powers, to recognise the denunciation. Shortly afterwards (October 9) Bismarck instructed Count Keyserling, the Prussian minister at Constantinople, to let the other legations, as. well as the Porte, see that a close and indissoluble entente existed between Prussia and Russia.

Then Prince Gortchakoff, having thus gained the Issue of support of Prussia and feeling confident that none of the $\begin{gathered}\text { circular by } \\ \text { Prince } \\ \text { Gortchakot }\end{gathered}$ other signatories of the treaty of 1856 was in a position to make war on Russia, issued his famous circular despatch, dated October 19/31, $1870(g)$.

' The successive alterations,' it said, 'which the transactions considered as the foundation of the European balance of power have undergone during late years,

(g) Hertslet, Map of Europe, vol. iii. p. 1892. 
have rendered it necessary for the Imperial Cabinet to inquire how far their results affect the political position of Russia. Among these transactions, that which interests Russia most directly is the treaty of March 18/30, 1856.' In the Russo-Turkish convention annexed to this treaty, Russia undertook to limit her naval forces to a minimum. The Black Sea was, in return, neutralised. 'By laying down this principle, the signatory Powers intended to remove any possibility of a conflict between the Powers bordering on the Black Sea, or between them and the maritime Powers. It was intended to increase the number of the territories which have been accorded the benefit of neutrality by the unanimous consent of Europe, and thus protect Russia herself from all danger of attack. A fifteen years' experience has proved that this principle, on which the safety of the whole extent of the Russian frontiers in this direction exclusively depends, is no more than a theory.' Whilst Russia was disarming in the Black Sea, Turkey maintained unlimited naval forces in the Archipelago and the Straits; France and England retained their power of concentrating their squadrons in the Mediterranean. The general treaty excluded the flag of war from the Black Sea, whilst the Straits Treaty excluded it only in time of peace. Owing to this contradiction, the Russian shores were exposed to attack. Moreover, the treaty itself has undergone modifications in practice, e.g. in regard to Moldavia and Wallachia, to which the signatories consented-the Russian representative alone drawing attention to the departure from the written stipulations. Other infractions occurred: foreign men-of-war were repeatedly allowed to enter the Straits, and 'whole squadrons' were admitted into the Black Sea. The danger for Russia thus increased. Hence, de jure, a treaty thus violated had no longer binding force, and, de facto, 
Russian security could no longer be allowed to depend on a fiction that failed to stand the test of time. Accordingly, Russia, having regard to her safety and dignity, was bound to withdraw from the stipulations in question, and, in the interests of peace, was prepared to come to an understanding with the Powers for the purpose of establishing a just and equitable arrangement on a more solid foundation.

In addition to the circular Note a special despatch, containing appropriate comments, was sent to each Special despatches : signatory Power $(h)$.

Great Britain.-Baron Brunnow declared to Lord to Great Granville (November 1) that the Treaty of Paris had destroyed the political equilibrium in the East to the detriment of Russia, and that the Tsar was compelled to regain his imprescriptible rights of sovereignty, the restriction of which rendered the existence of a great State abnormal. The southern coasts of Russia could not be left to the mercy of chance or caprice. What Russia felt bound to do England would herself have done in similar circumstances. Lord Palmerston, an enemy of Russia, had said, on the day following the signature of the Treaty of Paris, that the engagement would not last ten years; but Lord Granville, who was not hostile to Russia, would recognise the necessity for altering an Act which affected the security and the dignity of a great Power Finally, a conversation with Lord Russell in 1866, relative to the revision of the Treaty of Paris, was recalled.

Prussia.-Prussia was the first to be informed of the To Prussia. step taken by the Tsar. A letter from the Emperor to King William, and one from Gortchakoff to Bismarck,

(h) Goriainow, pp. $162 \mathrm{seq}$., who is followed here, as in several other cases where Russian official communications and originally secret documents are concerned. 
together with the circular Note, were brought to the Prussian headquarters in France. A copy of the circular was also handed by d'Oubril, the Russian minister in Berlin, to Thile, the Prussian Secretary of State. The Tsar, in his letter to the King (October 31), reminded him of his conversations in 1866 with Lieutenant-General Manteuffel, who had come to St. Petersburg with assurances of the King's sympathy and support in regard to the proceeding contemplated by Russia. The Emperor was hopeful that the King would not only receive the announcement favourably, but would also use his influence with the other Governments concerned to make them share his view and to assure them of Russia's pacific intentions. In the letter to Bismarck the Imperial Chancellor said he had no doubt as to the Emperor's step and the support of Prussia; and he concluded with the words: 'Vous vous persuaderez, une fois de plus, que nous ne voulons pas vous accorder une demi-confiance. Cela dit, je m'en remets à vos inspirations et je vous offre d'avance un serrement cordial de main que vous interpréterez, comme moi, dans le sens de la conviction : doch wir einander treu geblieben sind.'

To France. France.-Okouneff, the Russian chargé d'affaires in Paris, emphasised the disastrous consequences of the Crimean War and of the Treaty of Paris, and the necessity for remedying the evils brought about by a pernicious political system.

To Italy. Italy.-Baron Uxküll was directed to inform ViscontiVenosta, the Foreign Minister, that the Chancellor had no doubt as to the support of the Italian Government.

To Austria. Austria.-Novicoff, the Russian minister at Vienna, told Count Beust that an arrangement causing uneasiness and irritation to a great State could not be in the interests of Europe and especially in those of Austria.

To Turkey. Turkey.-The Russian chargé d'affaires at Constan- 
tinople, Staal, explained to the Grand Vizier, Ali Pasha, that Russia had no hostile intention or ill-will towards Turkey; that, on the contrary, the abnormal situation established by the Treaty of P'aris was a source of possible conflict between the two countries.

When the circular of October 31 was handed (November 7) to the Prussian minister, Thile, he expressed his admiration for the way it was drawn up, sympathised with its object, and thought that the moment was opportunely chosen; indeed, he paid a tribute to the moderation of Russia in that she did not demand, too, the restoration of Bessarabia. The following day, Prince Reuss, the Prussian minister at St. Petersburg, asked Gortchakoff whether it was possible to delay the contemplated step a few weeks, since Prussia's voice would then have a greater influence with England. The Imperial Chancellor replied, that the step was not to be taken, but that it had already been taken. On November 10 Bismarck's formal assurance of support was received.

Baron Brunnow received the circular Note in London British on November 9 ; but before he delivered it, Sir Andrew protest. Buchanan, the British ambassador at St. Petersburg, informed Gortchakoff of a rumour that reached him concerning Russia's contemplated action, and said that he could scarcely believe it; but if the rumour were confirmed, he would be obliged to ask for his passports. The rumour was very soon confirmed, and the passports were not demanded. But Lord Granville, the Foreign minister, immediately protested against the Note (November 10)(i). He emphasised that the power of releasing a signatory party from any or all of the stipulations of an engagement belongs to the States that are parties to the instrument. "The despatches of Prince

(i) Hertslet, Map of Europe, vol. iii. p. 1898. 
Gortchakoff,' he said, 'appear to assume that any one of the Powers who have signed the engagement may allege that occurrences have taken place which, in its opinion, are at variance with the provisions of the treaty, and, although this view is not shared nor admitted by the co-signatory Powers, may found upon that allegation, not a request to these Governments for the consideration of the case, but an announcement to them that it has emancipated itself, or holds itself emancipated, from any stipulations of the treaty which it thinks fit to disapprove. Yet it is quite evident that the effect of such doctrine, and of any proceeding which, with or without avowal, is founded upon it, is to bring the entire authority and efficacy of treaties under the discretionary control of each one of the Powers who may have signed them; the result of which would be the entire destruction of treaties in their essence. For whereas their whole object is to bind Powers to one another, and for this purpose each one of the parties surrenders a portion of its free agency, by the doctrine and proceeding now in question, one of the parties in its separate and individual capacity brings back the entire subject into its own control, and remains bound only to itself.' $\mathrm{He}$ concluded by saying that Great Britain would not have refused to consider, along with the other signatories, any representations that the Russian Government thought fit to make with regard to infractions of the treaty, or inconveniences of Russia occasioned by the altered circumstances.

Brunnow's reply.

In an interview between Granville and Brunnow, the latter, replying to the British contention that treaty stipulations could be legitimately abrogated only by the consent of all the parties thereto, pointed out two precedents to the contrary: first, in 1864, in the negotiations in London relative to the affairs of Denmark, when 
Lord Russell and Lord Clarendon acquiesced in the denunciation of the Treaty of London, 1852, by Prussia and Austria ; secondly, in 1866, in the case of the Prussian annexations, when Lord Stanley acquiesced in the consequent repudiation of the Treaties of Vienna, 1815. Moreover, the Russian ambassador observed that the principle of neutralising the Black Sea was not an English idea, but a French; and that the circunstances in which Napoleon had conceived this idea no longer existed; hence, he concluded, it was necessary to substitute a true international principle for 'a false theory henceforth devoid of practical value.'

In another interview Lord Granville stated that the Gortchakoff's form and suddenness of the Russian announcement view of deeply offended the Cabinet. Brunnow, however, was able to inform Gortchakoff that the British Government would prefer negotiation to conflict, unless public opinion compelled it to effect a rupture. The Imperial Chancellor, in reply, said that the English despatch was really a dissertation on the law of nations. Russia was prepared to negotiate with her co-signatories for the purpose of making the necessary alterations in the objectionable treaty. The form of abrogation was not of Russia's choice; on several occasions she made efforts to enter into negotiations on the question, but failed; and in the meantime her position was becoming more and more intolerable. The abrogation of a theoretical principle whereby Russia regained a right, of which no great Power could be deprived, could not be considered as a menace to peace; the annulment of one point of the treaty of 1856 did not imply the annulment of the whole.

As for France, the circular despatch was received at Attitude of Tours on November 17. Count de Chaudordy objected $\begin{gathered}\text { the other } \\ \text { Powers. }\end{gathered}$ to a unilateral denunciation; whereupon the Russian 
chargé d'affaires pointed out that the Treaty of Paris had several times been broken. Chaudordy then said that as France was then occupied with her own affairs, the question would have to be considered later; in the meantime he expressed himself in favour of a congress.

Italy was not opposed to a revision of the treaty, on condition that the Turkish Empire remained intact.

Austria was less inclined to compromise. When Count Beust protested against the sudden repudiation, he was reminded of the various violations of the treaty that had already been committed.

In Turkey there was great excitement on the receipt of the Note. The Russian representative, however, assured the Porte that his Government did not desire to attack the principle of closing the Straits, and that it did not seek territorial aggrandisement or preponderating influence in the East. But the Porte none the less objected to the form of the denunciation. The Prussian minister was directed by Bismarck to do all he could to alienate the Porte from England, and promote an understanding between Turkey and Russia $(k)$.

Opinion in the United States was on the side of Russia. Hamilton Fish, the Secretary of State, informed the Russian minister at Washington, that the American Government had never recognised the 'Treaty of Paris; and he even suggested the conclusion of an offensive and defensive alliance between the two Powers, if Russia would be prepared to support the United States in the Alabama affair. The Russian Government apparently was not struck by this suggestion, which fell to the ground.

Examination of the claims made in the circular.
-One or two observations may be made here on the Gortchakoff circular and the claims set forth in it. In 
the first place, it was a questionable stroke of policy, to say the least, to take advantage of the turmoil in Europe and suddenly proclaim the repudiation of solemn treaty stipulations just at the moment when France, originally their most enthusiastic supporter, was in the agony of her death-struggle. Gortchakoff used to regard Bismarck as his pupil; in 1870 he showed that there was indeed a certain kinship between them. As a French writer says: 'Il était d'une politique assez méprisable de profiter des défaites de la France pour rompre avec des engagements solennellement pris devant toute l'Europe: le chancelier Gortchakoff voulait sans doute se montrer capable de la souplesse et de l'esprit pratique du comte de Bismarck; les scrupules lui paraissaient aussi chose encombrante' $(l)$.

As to the allegation that numerous infractions of the Alleged Treaty of Paris had been committed by the signatories infractions. in sending 'whole squadrons' through the Straits, it appears, according to a return laid before Parliament $(1871)(m)$, that during the period of fifteen years $(1856$ -1871) nine foreign warships (other than the light vessels sanctioned by treaty) were allowed to pass the Straits. These included one British, two Austrian, one French, one Prussian, one Russian, and three American vessels. In seven other cases questions had arisen as to the passage of foreign warships, but in none had a violation of the treaty occurred. The United States was not a signatory party to the Treaty of Paris, so that the passage of her vessels cannot be regarded as breaches by the signatories. Among the other instances of passing, Russia herself appears-the warship Alexander Newski having passed the Straits on April 5, 1868; but

(l) E. Driault, La question d'Orient depuis ses origines jusqu'd nos jours (Paris, 1905), p. 204.

(m) Hertslet, Map of Europe, vol. iii. p. 1895.

$\mathbf{P}$. 
a complainant's contravention of a rule cannot be regarded as proof of the inapplicability of the rule: 'cette invocation,' aptly says a recent. writer, 'semble manifestement contraire à un principe moral, consacré en droit — "nemo auditur propriam turpitudinem allegans" ' $(n)$. According to the strict interpretation of the treaty, contraventions had undoubtedly been committed by securing the passage of warships through the prohibited waters. But the fundamental object of the treaty, viz. the Eastern settlement and the security of Turkey, was not endangered by admission of a few isolated vessels within a period of many years (o).

Claims as to dignity and sovereignty.

Again, Russia claimed that her dignity and rights of sovereignty and self-preservation were affected by the treaty. But almost every treaty of peace is a compromise whereby the defeated party's dignity and sovereignty are necessarily more or less affected. Juridically, a treaty of peace is regarded as a definitive settlement; so that under international law a signatory thereto is not entitled afterwards to repudiate any of its provisions. To do so on other grounds may or may not be in accordance with State policy or interest; but it is indubitably a violation of a solemn international engagement, and hence a violation of international law. As to the alleged interference with the right of self-preservation, the Russian Government had agreed not to maintain a fleet in the Black Sea on condition that that sea was neutralised; and as the principle of neutralisation remained applicable, whereby foreign fleets were excluded from its waters, the security of Russia on her southern coasts was not endangered. There was no guarantee, of course, that this principle would throughout continue to be respected by foreign Powers, and that in case of war

(n) Dascovici, op. cit. p. 230.

(o) Cf. W. E. Hall, International Law (Oxford, 1909), p. 346. 
between them and Russia their fleets would refrain from forcing the Straits, in case of Turkish neutrality, and entering the Black Sea to direct a blow at their enemy's most vulnerable point. There was admittedly much force in this argument.

Finally, Russia contended that owing to the changes Rebus sic which the fundamental relations of Europe had undergone in recent years, the circumstances in which the Treaty of Paris was concluded no longer existed; therefore this consideration, together with the fact that the original hardships imposed on Russia continued to exist, gave her the right to consider the objectionable articles of the treaty as no longer possessing validity. This raises the question of the-implied clause in treaties, viz. rebus sic stantibus. There is a difference of opinion on this point; but there is no doubt that the majority of jurists and publicists hold that in general a treaty is concluded with the implied condition that, if a fundamental or vital change in the circumstances should occur subsequently, so as to render the performance of the treaty virtually impossible, the stipulations thereby affected cease to be binding $(p)$.

'The clause rebus sic stantibus,' observed Bismarck, ' is tacitly understood in all treaties that involve performance' $(q)$. 'All contracts between great States cease to be unconditionally binding as soon as they are tested by " the struggle for existence." No great nation will ever be induced to sacrifice its existence on the altar of fidelity to contract when it is compelled to choose between the two. The maxim "ultra posse nemo

( $p$ ) For examples of American practice, see J. B. Moore, Digest of International Law. 8 vols. (Washington, 1906); vol. v. $§ 772$, pp. 335 seq.; J. W. Foster, The Practice of Diplomacy (1906), chap. 15.

(q) Bismarck the Man and the Statesman-being the reflections and reminiscences of Otto Prince von Bismarck. Trans. by A. J. Butler. 2 vols. (London, 1898); vol. ii. p. $2 \lessgtr 0$. 
obligatur" holds good in spite of all treaty formulas whatsoever, nor can any treaty guarantee the degree of zeal and the amount of force that will be devoted to the discharge of obligations when the private interest of those who lie under them no longer reinforces the text and its earliest interpretation' $(r)$. Similarly Bluntschli, who was a stout defender of the rules of international law as against the extravagant pretensions of Von Moltke $(s)$ in regard to military necessity $(t)$, maintained that a State, though bound to respect onerous conditions and engagements affecting its amour-propre, could refuse to perform such obligations as were incompatible with its existence or prevented its development $(u)$. And Heffter held that a contracting party may repudiate an engagement as soon as it conflicts with the well-being of the nation $(x)$. But such broad claims are juridically unjustifiable, for they involve an undue and arbitrary extension of the principle of rebus sic stantibus. If contracting States acted conformably thereto, and chose to denounce obligations as soon as the performance thereof became inconvenient or, in their own opinion, interfered with State policy, the whole practice of treaty-making would become nugatory; the more powerful of two signatories could withdraw at pleasure from its undertaking, and yet could compel the weaker to abide by it

(r) Bismarck the Man and the Statesman-being the reflections and reminiscences of Otto Prince von Bismarck. Trans. by A. J. Butler. 2 vols. (London, 1898); vol. ii. p. 270.

(s) See C. Phillipson, International Law and the Great War (Iondon, 1915), pp. $138-141$.

(t) For an examination of the doctrine of necessity, see International Law and the Great War, chap. ii. pp. 27 seq., 129, 134 seq.

(u) Das moderne Völkerrecht (Nördlingen, 1872), § 415: 'Auch ungünstige Vertragsbestimmungen und lästige Versprechen sollen gehalten werden. Vorbehalten bleibt das Recht eines States, sich von Verträgen loszusagen, welche mit seiner Existenz oder seiner nothwendigen Entwicklung unverträglich sind.'

(x) Das europäische Völkerrecht der Gegenwart (Berlin, 1882), § 98. F. H. Geffcken, the editor of Heffter's work, dissents from the views of both Heffter and Bluntschli ; cf. the French edition (1883), p. 221, note. 
even if the latter found it a disadvantageous arrange$\operatorname{ment}(y)$.

'If signatories are to be allowed' (we may be permitted to repeat what has been said in a recent publication $)(z)$, ' if signatories are to be allowed to repudiate . . . their deliberately executed engagements at their arbitrary will, then negotiation will become a hypocritical farce, relationships between States will rest on a precarious basis, and the community of nations will be hardly more than a name. Some refer the binding force of treaties to natural or moral law, to the moral consciousness of mankind, or to the innate sense of right in man. Some derive it from the self-limitation voluntarily imposed by the respective contracting parties. Others, again, attribute it to long-established custom. All these considerations are worthy of being taken into account; but for our present purpose we may say simply that if the binding force of treaties and international law is universally denied, treaties and international law cannot have any real existence, international transactions become impossible, and the society of States becomes a non-entity. But in the present condition of the world the existence of a society of States is inevitable; and therefore the non-existence of a system of international law is inconceivable. No doubt a State may at a certain moment think it advantageous or expedient to renounce an undertaking; but the dictates of honour and justice demand its observance. And honour and justice are eternal attributes of human worth and dignity, they are

(y) To claim, says Sorel, that obligations under treaties are susceptible of discretionary variation, amounts to declaring ' qu'il n'y a de droit public que pour les politiques naïfs, que les contrats diplomatiques n'obligent que les Etats trop faibles pour les déchirer, et ne protègent que les Etats assez forts pour les défendre.' (A. Sorel, Histoire diplomatique de la guerre franco-allemande (Paris, 1875), vol. ii. p. 91.)

(z) International Law and the Great War, p. 47. 
indispensable essentials of public life; without them international relationships, frank, harmonious, based on mutual understanding, are impossible. Indeed, in the long run it will even prove an advantage to a State to abide by its covenant; for in breaking its agreement when it happens to suit its purpose it is really sowing the wind to reap the whirlwind. The public welfare of a State, too, depends to a large extent on the common welfare of the society of nations; to the underlying principle of "sociality," reciprocal goodwill and mutual reliability are indispensable.'

The only ground on which the question of abrogation may arise is when circumstances have, since the conclusion of the treaty, changed to such an extent as to make its performance impossible; that is, that it would be unreasonable and unfair to expect its continued fulfilment. But a difficulty arises here-who is to decide whether the new conditions amount to impossibility of performance? If an authoritative International Court existed it would be called upon to determine whether the alleged change of circumstances was such as to justify an abrogation or alteration of the treaty. In the absence of such a court the complainant State is not therefore entitled to resort abruptly to a unilateral denunciation of its engagement; it is its duty to set forth before its co-signatories the grounds on which its objections are based, and invite them to meet in conference for the purpose of resolving collectively the difficulties that have arisen. That Russia had, on the whole, good. ground for complaint is indubitable; that the method she adopted for withdrawing from her engagement was in principle bad is equally undeniable $(a)$. This principle was, as we shall presently see, formally recognised

(a) Cf. J. S. Mill, article on 'Treaty Obligations' in Fortnightly Review (1870), New Series, vol. viii. p. 715. 
by the Powers, including Russia, in their Declaration of London. Some writers $(b)$ regard the latter as embodying a doctrine that 'sounds well,' but is 'as untenable as the lax view that would allow any party to a treaty to violate it on the slightest pretext.' It is argued that ' if it were invariably followed, a single obstructive Power would have the right to prevent beneficial changes that all the other States concerned were willing to adopt. . . . International Law certainly does not give a right of veto on political progress to any reactionary member of the family of nations who can discover in its archives some obsolete treaty, on the fulfilment of whose stipulations it insists against the wishes of all the other signatory Powers.' Such an argument begs the question in that it speaks of obstruction to progress, reactionary signatory, obsolete treaty, and the like. Indeed, it is a two-edged sword. What if an obstructive and reactionary party insisted, not on abiding by a treaty, but in tearing it up when its co-signatories wish the engagement to hold good? Moreover, when is a pretext for violating a treaty a 'slight one,' and when is it a suffcient ground? And who is to determine this? Obviously the view that a State may renounce a solemn engagement the moment it becomes irksome is a sinister solution that must inevitably produce conflicts and chaos in international relationships. In private law a court of justice decides when a contract may be set aside; in international law as it is to-day all the signatories must decide whether to liberate a party from a common convention or to make changes therein.

Negotiations were, however, soon begun for arranging Negotiations a Conference of the Powers concerned. Bismarck sug- Conferenoe.

(b) For example, T. J. Lawrence, The principles of international law (London, 1913), p. 328. 
gested St. Petersburg as the place of meeting, but Gortchakuff proposed London. Brunnow thought it undesirable to hold a Conference in London, on the ground that the British Government would be disposed to bargain as to the number of vessels to be maintained by Russia in the Black Sea, and he feared that a Conference there would prove abortive. Lord Granville, however, having accepted Gortchakoff's proposal, Brunnow eventually withdrew his objection.

At the end of November, 1870, Count Beust suggested that a preliminary meeting should be held in Constantinople between the representatives of Great Britain, Austria, Italy and Turkey, for the purpose of determining the basis for the London Conference, and especially the guarantees that should be substituted for the principle of neutralisation. Lord Granville objected to the proposal, which also offended Gortchakoff,-—'les intentions perfides du comte Beust indignèrent le prince Gortchakow' (c).

Russian view as to object of a Conference.

Bismarck agreed to take part in the Conference provided the Franco-German question were not introduced into the discussions. Turkey consented to participate therein on condition that the negotiations were confined to those provisions of the Treaty of Paris that Russia found objectionable. Gortchakoff, in a despatch to Brunnow, assumed that the Conference would not concern itself with preliminary deliberations, or with an entire revision of the Treaty of Paris, or with the conclusion of a new treaty, but rather with the complaints of Russia in regard to the stipulations that affected her security, dignity and honour. He thought that the Conference should meet as soon as possible, that its duration should be as short as possible, and that a convention-or rather a protocol-should be arrived at con-

(c) Goriainow, p. 213. 
formably to the Russian demands $(d)$. Soon afterwards Russia informed the Prussian Government that she was prepared to recognise the Black Sea as open to all vessels of all nations, but that she was afraid a proposal to this effect would be opposed both by Great Britain and by Turkey. The latter, however, might, if urged by the other Powers, consent to establish the freedom of the Black 'Sea provided she retained sovereignty over the Straits and the power to exclude vessels in certain cases.

After much negotiation relative to the order and form Meeting of of proceedings to be observed at the Conference, the first $\begin{gathered}\text { the London } \\ \text { Conference. }\end{gathered}$ meeting was held on January 17, $1871(e)$, without the French plenipotentiary, Jules Favre, who had not yet arrived $(f)$. Lord Granville proposed that a protocol should first be signed declaring the inviolability of treaties, and the incapacity of signatory parties to withdraw from any stipulations without the consent of the co-signatories. Brunnow agreed to sign on condition that the declaration would not operate retroactively. Bismarck approved of the proposal, and instructed Count Bernstorff to sign it. Eventually the following declation was agreed to and signed:

' The plenipotentiaries of North Germany, of Austria- Declaration Hungary, of Great Britain, of Italy, of Russia, and of character of Turkey, assembled to-day in conference, recognise that treaties. it is an essential principle of the law of nations that no Power can liberate itself from the engagements of a treaty, nor modify the stipulations thereof, unless with

(d) Ibid.pp. 208, 209.

(e) British and Foreign State Papers, vol. lxi. (1870-1871), p. 1193; English translation of the protocols in Parliamentary Papers, Turkey, No. 16 (1878); Treaties and other Documents relating to the Black Sea, the Dardanelles, and the Bosphorus, 1535-1877, p. 54.

$(f)$ As to the difficulties in regard to the representation of France and the long pourparlers with Prussia, see A. Sorel, Histoire diplomatique de la guerre franco-allemande (Paris, 1875), vol. ii. pp. 105 seq. 
the consent of the contracting Powers by means of an amicable arrangement.'

On January 23 an attempt was made by Lord Granville and Baron Brunnow to draw up clauses relating to the closing of the Straits and the rights of the Sultan.

The first clause was to this effect: The principle of the closing of the Straits of the Bosphorus and the Dardanelles in time of peace, established as an ancient rule of the Ottoman Empire, and confirmed by the Treaty of Paris, 1856, remains in force.

The second clause was as follows: The Sultan reserves to himself the power to open the Straits temporarily and exceptionally to fleets of friendly Powers, to -which Turkey may appeal in case her security is threatened.

Lord Granville insisted on substituting the expression 'non-littoral Powers' for 'friendly Powers'; and his view was supported by the Austrian and Italian plenipotentiaries. Afterwards Granville expressed his readiness to withdraw his proposal, on condition that the Conference accepted a clause restoring to the Sultan his rights of sovereignty.

Brunnow's

At the second plenary session ( $g$ ), January 24, Brunnow memorandum. read a memorandum in which he held that the provisions of the Treaty of Paris relating to the navigation of the Black Sea were objectionable, that the principle of neutralisation laid down in Art. XI., being inconsistent with Art. X. (which refers to the Straits Convention annexed to the general treaty), was fallacious, that stipulations forbidding littoral Powers, viz. Russia and Turkey, to enjoy their rights of sovereignty in a sea that washes their own territories exclusively were excessive, and, indeed, transcended the limits of the possible

(g) British and Foreign State Papers, vol. Ixi. (1870-1871), p. 1199; English translation in Parliamentary Papers, Turkey, No. 16 (1878), p. 57. 
when they declared such a condition of things to be perpetual. These stipulations, purporting to establish the pacification of the Levant, had a contrary effect; they perpetuated a source of irritation, and were increasingly obnoxious to the national feelings of Russia. Hence it was indispensable to find means for terminating this abnormal situation. The Turkish representative, Musurus Pasha, dissented from the opinion of Brunnow in regard to the principle of neutralisation. The Porte was desirous of maintaining it, but in the interests of conciliation and peace was prepared to accept the conclusions agreed to by the Western Powers, provided adequate guarantees were given instead of those furnished by the Treaty of Paris.

At a private meeting of the represertatives the fol- Draft treaty. lowing Articles were drafted, and were embodied in a special memorandum :-

'ART. I. The principle of the closing of the Straits of the Bosphorus and the Dardanelles in time of peace, invariably established as the ancient rule of the Ottoman Empire, and confirmed by the Treaty of Paris of March 30, 1856, remains in full force.

ART. II. His Imperial Majesty the Sultan, by virtue of the right of sovereignty which he exercises over the Straits of the Bosphorus and the Dardanelles, reserves to himself in time of peace the power to open them by way of temporary exception, in case only that the interests of the security of his Empire should cause him to recognise the necessity of the presence of vessels of war of non-riverain Powers.

ART. III. It is agreed that the stipulation contained in the preceding Article shall for the future replace those of Arts. XI., XIII., and XIV. of the Treaty of Paris of March 30, 1856, as well as the Special Convention con- 
Objections raised.

cluded between Russia and Turkey, and annexed to the said Art. XIV.

ArT. IV. The high contracting parties renew and confirm all the stipulations of the Treaty of March 30, 1856, as well as of its annexes, that are not annulled or modified by the present treaty.'

The expression 'non-riverain Powers' of Art. II. brought forth objections. According to the literal meaning of the Article, it seemed that the Sultan would not be empowered to open the Straits to his own warships as well as to those of Russia. Obviously this could not have been the intention of the plenipotentiaries. Russian opinion considered this form of expression as a trap due to Austrian intrigues $(h)$. The representatives, however, immediately realised the absurdity of the draft Article as it stood. Musurus Pasha then proposed to substitute the words 'foreign Powers' for the words 'non-littoral Powers.' There was some confusion in regard to the application of the expression 'non-littoral Powers.' It was taken to refer to the shores of the Black Sea, and not to the Straits with which Art. II. was concerned. Eventually Brunnow notified his acceptance of the draft. In a communication from Prince Gortchakoff to General Ignatieff, January 24, the Imperial Chancellor thought that the insistence on the expression 'non-riverain' (non-littoral) almost amounted to a confession of weakness on the part of the British Government; its wavering position-'assiette chancelante'-was thereby betrayed. He observed that Brunnow did not wish to refuse Granville this 'puerile rampart' against parliamentary opposition. The barrier established by the controverted phrase of Art. II. would, when the first occasion arose, fall down like a house of cards $(i)$. Owing to misunderstanding due to the de-
(h) Goriainow, p. 247.
(i) Ibid. p. 255. 
fective drafting of Art. II., the Russian representative intimated, before the second sitting ended, that in his view the words ' non-littoral' included his country. The Turkish delegate then proposed, as an amendment, that 'friendly Powers.' should be substituted for 'non-littoral Powers.' Then Granville and Brunnow came to an agreement as to the fifth clause, whereby the Black Sea was to remain open for merchantmen; and it was decided that if the expression 'non-littoral Powers' was retained, the words ' of the Black Sea' should be added thereto.

The third session $(k)$ was opened by Lord Granville $\begin{gathered}\text { Turkish } \\ \text { counter- }\end{gathered}$ (February 3), who recapitulated the provisions reached proposal. at the preceding meeting. Musurus Pasha then presented a counter-proposal, of which he had given notice, to the following effect: (1) As long as the Porte was at peace, the Straits should be closed to all warships except light vessels employed in the service of the legations, and on the Danube. (2) The Porte reserved to itself the right to open the Straits in time of peace to the warships of friendly and allied Powers, in case the interests and security of Turkey demanded it. The Turkish representative endeavoured to open a discussion on the Eastern Question generally, but Brunnow objected, and referred to the resolve of his Emperor to confine the deliberations to the obnoxious stipulations of the treaty of 1856. Furthermore, Brunnow urged the insertion of the words 'non-littoral Powers' instead of 'friendly Powers'; to which Musurus replied that he suggested 'friendly Powers,' because Turkey did not wish to be restricted in her alliances, or to arouse the discontent of Russia. The Austrian representative now proposed that, for the sake of clearness, the words 'of the Black Sea'

(k) British and Foreign State Papers, vol. lxi. (1870-1871), p. 1205; English translation in Parliamentary Papers, Turkey, No. 16 (1878), p. 61 . 
should be added at the end of Art. II. of the draft; and all, except Musurus, agreed to the original form.

Next followed a discussion on the clauses relative to the navigation of the Danube, and it was decided to prolong the European Commission for a period of twelve years.

Attitude of Turkish delegate.

The fourth sitting of the Conference was held on February $7(l)$. The situation appears now to have been a very difficult one, owing, on the one hand, to the perplexing attitude of the Ottoman representative, and, on the other, to the competition between the terms 'nonlittoral Powers' and 'friendly Powers.' It was thought that Musurus Pasha was playing a double game, and was endeavouring to break up the Conference before an agreement was reached. Baron Brunnow and Lord Granville made several efforts to come to an understanding as to the second Article of the draft. Brunnow urged that the expression 'non-littoral Powers' was inadmissible, first, because its meaning was doubtful, and secondly, because it affected the Sultan's rights of sovereignty. Granville was prepared to withdraw the expression, on condition that provision was made in express terms for the independence and integrity of the Ottoman Empire. Such a provision the Russian plenipotentiary was willing to accept, if it was understood in the sense of Art. VII. of the Treaty of Paris, which applied only to foreign aggression and not to internal dismemberment.

Acceptance of Italian

At this juncture, Count Barbolani, the Italian minister amendment. at Constantinople, submitted an amendment in the hope of satisfying the contending parties. It was to the effect that the Sultan should be entitled to open the Straits to the fleets of friendly and allied Powers, when

(l) British and Foreign State Papers, vol. lxi.(1870-1871), p. 1218 ; English translation, Parl. Papers, Turkey, No. 16 (1878), p. 68. 
he found it necessary to do so for the purpose of ensuring the performance of the Treaty of Paris. Eventually this amendment was accepted by all the plenipotentiaries; and then Brunnow and Count Bernstorff drew up the amended form of the treaty.

. Soon after the opening of the parliamentary session, Criticism in which took place just then (February 9 ), the Government Commons. was blamed for consenting to revise the Treaty of Paris. Mr. Gladstone replied that Lord Palmerston had always been of the opinion that the neutralisation of the Black Sea could not be a durable arrangement, and that Lord Clarendon had shared this view $(m)$. He added that both France and Austria had formerly brought forward proposals in favour of revising the principle of neutralisation.

The last sitting $(n)$ of the Conference was held on The Treaty of March 13, when the draft treaty was, with certain modifications, formally accepted by all the plenipotentiaries, including the Duc de Broglie, the French representative, who was then able to be present. On the following day they affixed their signatures to the now treaty $(o)$, which was dated March 13 ; and on the 16th the Russian and Ottoman plenipotentiaries signed a separate convention (superseding their special convention of March 30,1856), which was also dated March 13. Arts. IV.-VII. deal with the Danube; the Articles relating to the Bosphorus, the Dardanelles, and the Black Sea, are as follows:

'ART. I.-Arts. XI., XIII. and XIV. of the Treaty of Paris of the 30th March, 1856, as well as the special convention concluded between Russia and the Sublime

(m) Cf. Hansard, Parliamentary Debates, 3rd ser. vol. cciv. p. 850.

(n) British and Foreign State Papers, vol. Ixi. (1870-1871), p. 1219; English translation in Parliamentary Papers, Turkey, No. 16 (1878), p. 69.

(o) Hertslet, Map of Europe, vol. iii. p. 1919. 
Porte, and annexed to the said Art. XIV., are abrogated, and replaced by the following Article.

ART. II.-The principle of the closing of the Straits of the Dardanelles and the Bosphorus, such as it has been established by the separate convention of the 30th March, 1856, is maintained, with power to His Imperial Majesty the Sultan to open the said Straits in time of peace to vessels of war of friendly and allied Powers, in case the Sublime Porte should judge it necessary in order to secure the execution of the stipulations of the Treaty of Paris of the 30th March, 1856.

ART. III.-The Black Sea remains open, as heretofore, to the mercantile marine of all nations.

ART. VIII.- The high contracting parties renew and confirm all the stipulations of the Treaty of the 30 th March, 1856, as well as of its annexes, which are not annulled or modified by the present treaty.'

Separate convention between Russia and Turkey.

Effect of the Treaty of London.
The separate convention $(p)$ between Russia and Turkey is to this effect: 'ART. I.-The special convention concluded at Paris between His Majesty the Emperor of All the Russias and His Imperial Majesty the Sultan on the 18/30th March, 1856, relative to the number and force of the vessels of war of the two high contracting parties in the Black Sea, is and remains abrogated.'

Thus the Treaty of London legalised the de facto situation created by Russia's unilateral denunciation of certain Articles of the Treaty of Paris which had prohibited her from establishing a navy in the Black Sea. She was now at liberty to build and maintain a fleet there, to restore the fortifications of Sebastopol, and so was in a position to become once more a direct menace to Constantinople. The rule as to closing the Straits was maintained as under the treaties of 1841 and 1856 .

(p) Hertslet, Map of Europe, vol. iii. p. 1924. 
By way of compensation to the Sultan for the discontinuance of the neutrality of the Black Sea, his power with regard to the Straits was enlarged: before 1871 he was not entitled, so long as he was at peace, to admit foreign warships; by the Treaty of London, though the principle of closing was maintained, he was empowered to open the Straits in time of peace to the military flag of friendly and allied Governments if he thought it necessary for ensuring the performance of the unrevoked Articles of the treaty of 1856. The Treaty of London, 1871, is the last international Act regulating the legal position of the Bosphorus and the Dardanelles - the Congress of Berlin, 1878, simply recognised it without adding to or modifying it in any way. But the application of the treaty has given rise to difficulties, as we shall see $(q)$.

(q) See infra, Chap. VIII. 


\section{CHAPTER VII.}

THE RUSSO-TURKISH WAR-THE TREATY OF SAN STEFANOTHE TREATY OF BERLIN.

The Triple During the Franco-Prussian War Bismarck had deterAlliance.

mined to establish an alliance with Russia and Austria as against any possible coalition that might be directed against Germany. In September, 1870, he approached the cabinets of St. Petersburg and Vienna on the question of a Triple Alliance, which he thought might subsequently be extended by the admission of Italy. Two years later (September, 1872) he succeeded in bringing about a meeting of the three Emperors at Berlin. 'I have thrown a bridge across to Vienna,' said the Iron Chancellor, 'without breaking down that older one to St. Petersburg.' The result of the Imperial interview was not a formal treaty, but none the less a definite entente between the three Powers-a kind of 'Holy Alliance'-with a view to maintaining peace generally on the basis of existing conventions, and to making a common stand against misgovernment and revolutionary movements. In 1873 a Russo-German treaty was concluded, and in the same year King Victor Emmanuel's visit to Berlin testified to the friendly attitude of Italy and to her leaning towards the league of the three Great Powers. An important result of the Russo-Austrian rapprochement, so far as the near Eastern affairs were concerned, was a recognition by Russia of Austria's right of influence in Slav countries, in which Russia had till then jealously guarded her supremacy.

Panslav movement.

In the meantime the panslav movement in Russia 
was growing, and the tearing away of her fetters by the Treaty of London gave it a great impetus. On the other hand the treaty had increased the suspicion and distrust of Turkey towards the Christian Powers, whose constant intervention the Mussulmans resented and whose influence they were auxious to counteract. To oppose the activities of the Russian agents in the Ottoman dominions and the tide of Christendom, the 'Young 'Turkey' party came into existence and resolved to unite all true believers-a task encouraged by the rivalry of the Christian peoples of the Balkan peninsula. Thus panslavism found itself opposed by panislamism $(a)$.

Owing to Mussulman maladministration and oppres- Rising of the sion, a rising of the Christian population-fanned by phopulation panslavist propaganda-broke out in the Herzegovina Balkans, 1875. in 1875. The revolt soon spread into Bosnia; and help came from Serbia and Montenegro, Attempts to put down the insurrection failed. The intervention of the consuls of the Powers proved fruitless: the insurgents could not rely on promises of reform made by the Porte. Then followed Count Andrassy's note (b)--approved by England and France-to the Ottoman Government (January 31, 1876), and another effort of the three Emperors to effect a conciliation by means of the Berlin Memorandum (c) (May 13, 1876), which, however, was not accepted by England, pledged, as she was, to Disraeli's turcophil policy. A British fleet then arrived in Besika Bay. 'The 'Bulgarian atrocities,' May, 1876, aroused the indignation of Europe. On May 29 Sultan Abd-ul-Aziz was deposed, and four days later he was dead. Serbia and Montenegro now took up arms and declared war (July 1 and July 2 respectively).

(a) E. Driault, La question d'Orient, p. 208.

(b) Hertslet, Map of Europe, vol. iv. pp. $2418 \mathrm{seq}$.

(c) 1bid. pp. 2459 seq. 
Meeting of the Emperors at Reichstadt, 1876.

'Ihe Tsar's interview with the British Ambassador, 1876 .
On July 8, 1876, the famous meeting of the Emperors Alexander and Francis Joseph at Reichstadt took place; the latter engaged to observe neutrality in the event of a Russo-Turkish war, on condition that he should be permitted to occupy Bosnia and the Herzegovina. Thus the way was opened to Russian intervention. In order to prevent this, however, Great Britain offered her mediation, proposing the maintenance of the status quo in Serbia and Montenegro, and autonomy for Bosnia, Bulgaria, and the Herzegovina. The Powers agreed to these terms; which were then presented to the Ottoman Government (September 25), but without success. The British ambassador next demanded a month's armistice, but the Porte made unsatisfactory counter-proposals. In these circumstances Russia took a decisive step to prevent the annihilation of Serbia; General Ignatieff delivered an ultimatum, demanding the conclusion of an armistice within forty-eight hours with Montenegro as well as with Serbia. The Porte yielded, and signed a two months' armistice (November 1), which was afterwards extended to March 1, 1877, when peace was established between the Sultan and Prince Milan.

On November 2 the Tsar had a remarkable interview with Lord A. Loftus, the British ambassador $(d)$, to whom he declared that the Russian ultimatum was intended only to prevent the complete destruction of the Serbs and a repetition of such massacres as had taken place in Bulgaria. The efforts of the European concert to restore peace having failed, he could no longer acquiesce in the repeated Turkish rebuffs which affected his country's honour, dignity, and interests. Therefore if the Powers did not take an effective step collectively,

(d) Despatch from Lord A. Loftus to the Earl of Derby, dated Yalta, November 2, 1876 ; received by the Earl of Derby, November 14, 1876 : Hertslet, Map of Europe, vol. iv. pp. 2506 seq. 
he would be compelled to move alone (e). 'His Majesty then referred more especially to his relations with England. He said he regretted to see that there still existed in England an "inveterate" suspicion of Russian policy, and a continual fear of Russian aggression and conquest. He had on several occasions given the most solemn assurances that he desired no conquest; that he aimed His assurat no aggrandisement, and that he had not the smallest Turkey. wish or intention to be possessed of Constantinople. All that had been said or written about a will of Peter the Great and the aims of Catherine the Second were illusions and phantoms; they never existed in reality, and he considered that the acquisition of Constantinople would be a misfortune for Russia. There was no question of it, nor had it ever been entertained by his late father, who had given a proof of it in 1828, when his victorious army was within four days' march of the Turkish capital: His Majesty pledged his sacred word of honour in the most earnest and solemn manner that he had no intention of acquiring Constantinople, and that, if necessity should oblige him to occupy a portion of Bulgaria, it would only be provisionally, and until peace and the safety of the Christian population were secured.' He then emphasised the desirability of an understanding between England and Russia, based on a peace policy that would be beneficial not merely to the two countries but to Europe at large. The alleged Russian designs on India were absurd; a conquest of India was a 'perfect impossibility' $(f)$. The Emperor appealed to Great Britain to dispel the cloud of suspicion and distrust of Russia.

These pacific assurances of the Tsar were confirmed confirmation by Prince Gortchakoff in his despatch, dated Novem- by Gort-

(e) Hertslet, Map of Europe, vol. iv. p. 2508.

(f) Ibid. p. 2510. 
ber 3, to Count Shuvaloff, who communicated it to the Earl of Derby on November 18 $(g)$ : 'I see with profound surprise by your last letter that ideas of our coveting Constantinople and of the will of Peter the Great continue to haunt the minds of some people in England. I confess I thought these absurdities were out of date, had been dismissed, together with the conquest of India by Russia, to the domain of political mythology. How often have not the Russian Emperors publicly asserted that no territorial annexation enters into their policy; that they would be much embarrassed by it, and that the maintenance of the status quo of the East was the best combination. In our form of Government the word of the sovereign is not, like a parliamentary declaration, revocable at the will of a majority. Their personal loyalty is at stake. How many times, moreover, have not facts confirmed this. If Russia had these desires she would do what annexing Powers do. She would quietly make her preparations, and act on the first favourable occasion. Had she not such an opportunity in 1829 , in 1848 , and 1870 , when the attention and the forces of Europe were engaged elsewhere? What proofs, then, is it necessary to give English ministers of a disinterestedness, founded not on political virtue but on reason and good sense? If they would just forget for one moment that they are English, and place themselves at a Russian point of view, we would ask them whether, conscientiously, they would advise the Imperial Government to seek the possession of Constantinople. There can be no doubt as to the reply. Why deny us the practical good sense they themselves have? The only rational combination for Russian interests is to leave the keys of the Black Sea in hands feeble enough not to close to Russia that commercial

(g) Hertslet, Map of Europe, vol. iv. p. 2513. 
outlet nor to menace her security. The Turkish rule fulfilled this programme.' After remarking on the benefits to be derived from an Anglo-Russian understanding, he declared that the Eastern Question was not only a Russian question, for it involved 'the repose of Europe, peace and general prosperity, humanity, and Christian civilisation' $(h)$.

Having regard to these pronouncements, and to com- Lord Derby's munications from the Powers expressing a feeling that Conference. the questions arising out of recent events in Turkey could be satisfactorily settled in concert, the Earl of Derby made proposals (November 4 ) for a Conference to be held at Constantinople $(i)$. He submitted as the basis for the deliberations two fundamental principles: the independence and the territorial integrity of the Ottoman Empire; and a declaration (which had been made in 1840 in the case of the pacification of the Levant and in 1860 in that of Syria) that the Powers in intervening did not seek territorial advantages or exclusive commercial privileges. On November 19 Russia accepted the proposal, and expressed again her pacific intentions.

Preliminary meetings of the representatives of the Preliminary Powers were held at Constantinople December 11-22, meetings, 1876. 1876 , and the result of the deliberations was submitted to the formal Conference, which met on December 23 under the presidency of Safvet Pasha. On December 11 the Constitution of the Ottoman Empire was proclaimed as a set-off to the interposition of the Powers. The Porte refused afterwards to accept the proposals made at the Conference, which was accordingly closed on January 20, 1877. Safvet Pasha, in his despatch dated January $25(k)$ (communicated to the Earl of Derby by

(h) Ibid. p. 2514.

(i) Ibid. p. 2516.

(k) Ilid. pp. 2545 seq. 
Musurus Pasha, February 8), stated that his Government could not accept a progranme which was in several points inconsistent with the sovereignty and independence of the Sultan in his internal administration, as

Collective Note to the Porte, March, 1877.

Convention of Bucharest, 1877. recognised by the Treaty of Paris. On March 31 a collective Note was despatched to the Porte, as a result of a Conference between the Powers in London, laying down provisions for a settlement; and Russia appended a declaration-amounting to an ultimatum-that if Turkey accepted the advice of Europe she was to send to St. Petersburg a special envoy to treat of disarmament. Safvet Pasha's reply (dated April 9, and communicated to the Earl of Derby, April 12) $(l)$ was a protest against the protocol of March 31 ; he mentioned the opening of the Ottoman Parliament (March 19), which would prepare the way for better administration. and ensure equal liberty and justice to all, referred to the discourteous abruptness of the Russian declaration, and concluded by expressing confidence in his country's good cause: 'In face of hostile suggestions, unmerited suspicions, and manifest violations of her rights-violations which are at the same time violations of international law-Turkey feels that she struggles at the present moment for her very existence.'

Russia refused to wait any longer. On April 16 she concluded the Convention of Bucharest with Roumania (m), whereby Prince Charles sanctioned the passage of Russian troops through his territory, and the Tsar, in return, undertook to maintain the political rights of the principality and maintain and defend its territorial integrity. Then a Russian circular $(n)$ (dated April 19) was despatched, announcing that the armies of the Tsar

(l) Hertslet, Map of Europe, vol. iv. pp. 2568 seq.

(m) Ibid. p. 2576.

(n) Ibid. pp. 2586, 2587. 
had been ordered to invade Ottoman territory, and Invasion setting forth the causes of the war. It declared that as all attempts to effect a conciliation had failed, there was no other alternative but ' to seek to obtain by coercion what the unanimous efforts of the Cabinets have not succeeded in obtaining from the Porte by persuasion,' and invited the co-operation of the Great Powers in the task thus undertaken.

A few days later (April 24) Turkey appealed to the Turkey's Powers (o) for their mediation in accordance with Powers. Art. VIII. of the Treaty of Paris: "If there should arise between the Sublime Porte and one or more of the other signing Powers any misunderstanding which might endanger the maintenance of their relations, the Sublime Porte and each of such Powers, before having recourse to the use of force, shall afford the other contracting parties the opportunity of preventing such an extremity by means of their mediation.' Immediately afterwards (April 25) the Porte made a formal protest $(p)$ to the Powers against the Tsar's declaration of war and the invasion of its territory. This was followed (May 1) by a despatch to St. Petersburg from the Earl of Derby $(q)$, who expressed the disapproval of the British Government of the Russian invasion, and declared it to be contrary first to the Treaty of Paris whereby Russia and the other signatories agreed to respect the independence and territorial integrity of the Ottoman Empire, and secondly to the Declaration of 1871, signed by Russia and the other Powers, which said that no party to a treaty may denounce it or modify its stipulations without the consent of the other parties to it.

Then Lord Derby, in a note to Prince Gortchakoff Lord Derby's 
British interests, May, 1877
(May 6) (q), defined British interests in the East which, if imperilled, Her Majesty's Government would be bound to defend: 'Foremost among them is the necessity of keeping open, uninjured and uninterrupted, the communication between Europe and the East by the Suez Canal. An attempt to blockade or otherwise to interfere with the canal or its approaches would be regarded by them as a menace to India, and as a grave injury to the commerce of the world. On both these grounds any such step-which they hope and fully believe there is no intention on the part of either belligerent to takewould be inconsistent with the maintenance by them of an attitude of passive neutrality. The mercantile and financial interests of European nations are also so largely involved in Egypt that an attack on that country, or its occupation, even temporary, for purposes of war, could scarcely be regarded with unconcern by the neutral Powers, certainly not by England.' With regard to Constantinople and the Straits the following pronouncement was made: "The vast importance of Constantinople, whether in a military, a political, or a commercial point of view, is too well understood to require explanation. It is, therefore, scarcely necessary to point out that Her Majesty's Government are not prepared to witness with indifference the passing into other hands than those of its present possessors, of a capital holding so peculiar and commanding a position. The existing arrangements made under European sanction which regulate the navigation of the Bosphorus and the Dardanelles appear to them wise and salutary, and there would be, in their judgment, serious objections to their alteration in any material particular.' After referring to other interests on the Persian Gulf, and expressing a hope that the hostilities would be confined to such limits

(q) Hertslet, Map of Europe, vol. iv. pp. 2615-2617. 
as would render possible the maintenance of British neutrality, the note concluded by reminding the Russian Government of the Tsar's recent assurances that he had no intention to acquire Constantinople, or to occupy permanently Bulgarian territory.

Prince Gortchakoff, in his reply (dated May 18, com- Gortchakoff" municated to Lord Derby June 8) (r), stated that Russia would not menace the navigation of the Suez Canal, or bring Egypt within the radius of her military operations although that country is part of the Ottoman Empire, or extend the war so as to endanger British interests on the Persian Gulf and the route to India. 'As far as concerns Constantinople, without being able to prejudge the course or issue of the war, the Imperial Cabinet repeats that the acquisition of that capital is excluded from the views of His Majesty the Emperor. They recognise that, in any case, the future of Constantinople is a question of com. mon interest, which cannot be settled otherwise than by a general understanding, and that if the possession of that city were to be put in question, it could not be allowed to belong to any of the European Powers. As regards the Straits, although their two shores belong to the same sovereign, they form the only outlet of two great seas in which all the world has interests. It is, therefore, important, in the interests of peace and of the general balance of power, that this question should be settled by a common agreement on equitable and efficiently guaranteed bases.'

'The foregoing note was supplemented by a confi- Assurances dential communication of Count Shuvaloff (June 8), who repeated. repeated his Government's assurances regarding the Suez Canal, Egypt, the Persian Gulf, and India, but on the question of Constantinople and the Straits made the following significant observations: 'With regard to

(r) Ibid.pp. 2624-2627. 
Constantinople our assurances can only refer to taking possession of the town, or occupying it permanently. It would be singular and without precedent if, at the outset of a war, one of the belligerents undertook beforehand not to pursue its military operations up to the walls of the capital. It is not impossible that the obstinacy of the Turks, especially if they know themselves to be guaranteed against such an eventuality, may prolong the war instead of bringing it to a speedy termination. When once the English ministry is fully assured that we shall under no circumstances remain at Constantinople, it will depend upon England and the other Powers to relieve us of the necessity of even approaching the town. It will be sufficient for them to use their influence with the Turks, with a view to making peace possible before this extreme step is taken. On our side we shall willingly fall into this view. With regard to the Straits, the arrangements by virtue of which the Black Sea, which is closed in time of peace, is opened in time of war to all fleets hostile to Russia, were conceived in a spirit of distrust and enmity towards her. It is a question which can only be resettled by a general agreement, in such a manner as to guarantee the Black Sea against the consequences of the abnormal and exceptional position of the Straits. Would it be possible for Russia, at the outset of a war which may end fortunately for her, to undertake not to make Europe appreciate the necessity of a resettlement of a state of things which was established to her prejudice?' Count Shuvaloff concluded by emphasising the necessity for coming to an understanding on the essential object of the war and on the limit of military operations, and suggesting conditional terms of peace which involved a re-adjustment of the Balkans and an indemnity to Russia. 
had crossed both the European and Asiatic frontiers of Turkey. Montenegro had taken up arms, and was followed by Roumania after the Turkish bombardment of Calafat. Towards the end of June the Russians crossed the Danube into the Dobrudja, and Sistova. Gurko then captured Tirnovo (July 7), entered Kazanlik (July 13), and took the Shipka Pass. It now seemed as though the way was opened to Adrianople and the Ottoman capital. Changes were then made in the Ottoman command, and the tide turned. Gurko was driven back to the Balkans, and Osman Pasha occupied Plevna, which was then besieged by the allied Russian and Roumanian forces under Prince Charles. On December 10, the supplies of Plevna having become exhausted, Osman was compelled to surrender after having performed deeds of great valour. The Russian hopes of reaching Stamboul, which had been waning, were now in the ascendant again. Turkish reverses followed. The Serbs, who declared war again on December 14, and the Montenegrins inflicted defeats on the Ottoman armies. Gurko was now advancing irresistibly; he took Sofia on January 5, 1878, routed Suleiman near Philippopolis, and on January 20 entered Adrianople.

The Russian progress caused 'great alarm in Europe, Alarm in especially in the case of Great Britain and Austria. Soon after the fall of Plevna Lord Derby addressed a memorandum (dated December 13) $(s)$ to Count Shuvaloff reminding him of the Tsar's assurances as to the acquisition of Constantinople, and declaring that it was most desirable to avoid even its temporary occupation for purely military purposes. Should an attempt be made British threat. to occupy Constantinople or the Dardanelles, Great Britain would be compelled to abandon her neutrality and take whatever steps might be necessary for the

(s) Hertslet, Map of Europe, vol. iv. pp. 2646, 2647. 
protection of her interests. She was, moreover, ready to assist in the work of mediation and in the restoration of peace. In reply $(t)$ (dated December 16, received January 2, 187.8) Gortchakoff observed that the Turks would only prolong their resistance, if they were convinced that Great Britain would intervene in the event of an attack directed against their capital, and repeated the Tsar's promises regarding Constantinople in the terms stated in the despatch of May 18, $1877(u)$. He asked, moreover, for a clearer definition of British interests, with a view to an understanding. Whereupon Her Majesty's Government expressed the view (January 13) that 'any operations tending to place the passage of the Dardanelles under the control of Russia would be an impediment to the proper consideration of the terms of a final settlement,' and expected, therefore, that Russian forces would not be sent to Gallipoli $(x)$. Assurances to this effect were then given (January 15) on condition that the Turkish regular troops would not be concentrated on that peninsula, and that England herself would not occupy it.

A RussoTurkish treaty and the Powers.

When it became known in England that the Sublime Porte was contemplating the conclusion of an armistice with a view to a settlement, the 13ritish Government informed Gortchakoff (January 15) that a treaty entered into by the belligerents, affecting the treaties of $18 j 6$ and 1871, must be a European treaty, and would not be regarded as valid without the assent of the parties to those treaties $(y)$. Conditions of Russia had by now decided on the fundamental con-
peace.

ditions of peace. Of these the principal provision, as Nelidoff said, was that relating to the Straits. He em-

( $t$ ) Hertslet, Map of Europe, vol. iv. pp. 2653-2655.

( $\iota)$ See supra, p. 139.

(x) Hertslet, p. 2656.

(y) Ibid. p. 2657. 
phasised that the main object of Russian maritime policy in regard to Turkey must be and always was to secure free communication with the Mediterranean and at the same time to prevent enemy fleets from menacing the The Straits Black Sea coasts of Russia. Hence she must endeavour warbhips. to establish such combinations as would assure to her warships freedom of navigation in the Straits, and would exclude therefrom all other military flags. Considering the existing condition of the Black Sea fleet, Russia, he thought, would not be able for many years to despatch a squadron strong enough to exercise considerable influence in the Mediterranean archipelago, especially in comparison with the British fleet. But it was of great importance for her to be able to send isolated warships through the Straits, and particularly to receive freely in the Black Sea vessels acquired from foreign countries or

- ordered to be built abroad or in her own yards in the northern seas. As for Turkey, though her fleet then was and perhaps would for some time after the war remain numerically stronger than that of the Tsar, the operations of the war had proved that it could do little damage. The existing rule of the Straits might, then, be modified so as to empower Russia to send, with the authorisation of the Porte, isolated warships through the Bosphorus and the Dardanelles $(z)$. This suggested principle of closing to the foreign military flag, and opening to isolated vessels of the riverain States, under the Sultan's firman, was communicated to the Emperors William and Francis Joseph on January 4, 1878. Andrassy expressed himself in favour of closing, and considered the stipulation relative to the passage of isolated vessels as a detail of small importance.

When Prince Gortchakoff announced to Count Shuvaloff the proposed terms of peace, of which the ninth

(z) Goriainow, pp. 355, 356. 
clause stipulated for the closing of the Straits to foreign warships, and the opening to isolated warships of the littoral States under the Sultan's authorisation, which he would be bound to grant every time a request was made, the Russian ambassador observed $(a)$ that that clause would raise more storms in England than the principle of the freedom of the Straits for all. The English feared the latter principle, in spite of the basis of reciprocity; but to grant the right to Russian warships alone-for Turkish vessels already possessed it-would be considered a monopoly of Russian dominion in the waters of the Black Sea, the Bosphorus, and the Dardanelles. Russia would thereby also be able to transfer one by one her vessels from the Baltic to the Black Sea-an eventuality, he thought, that was 'the nightmare of the English.' Finally, the establishment of the proposed rule would, in the case of a Russo-Turkish entente, constitute a serious danger to the communications of Great Britain with her Indian Empire. In view of considerations of this kind Russia did not hesitate to assure Her Majesty's Government that the settlement of the Straits Question belonged to the Powers collectively.

Convention of Adrianople, Jan. 1878 .
On January 31, 1878, the Convention of Adrianople (b) was signed, providing for the conclusion of an armistice (which was effected the same day), and setting forth the basis of peace. The latter related to the future position of Bulgaria, Montenegro, Roumania, Serbia, Bosnia and Herzegovina, as well as an indemnity to Russia. The most important question of all, viz., that of the Straits, was left in the following form: 'His Imperial Majesty the Sultan shall come to an understanding with His Majesty the Emperor of Russia in order to secure the

(a) Goriainow, p. 358.

(b) Hertslet, pp. 2658-2660. 
rights and interests of Russia in the Straits of the Bosphorus and the Dardanelles.'

When, after the conclusion of the armistice, the Grand British war. Duke Nicholas advanced his headquarters to Chatalja, Marmara. within sight of the Turkish capital, a part of the British fleet was ordered to enter the Bay of Marmara for the purpose of protecting British life and property in Constantinople. War between the two Great Powers thus seemed to be imminent. Austria, too, complained that some of the stipulations in the Convention of Adrianople affected her interests. To complicate the situation Greece declared war on Turkey (February 2), thinking the moment opportune for securing territorial additions. The Greek move, however, was soon suppressed by the united protests of the Powers. With regard to the action of the British warships, Count Shuvaloff informed Lord Derby that if they came to Constantinople Russia would consider herself liberated from all the assurances given as to Constantinople and Gallipoli. When the vessels were anchored off the island of Prinkipo (February 2) the Sultan appealed to the Tsar not to take aggressive steps against the capital, and promised to communicate at once with Queen Victoria to secure the withdrawal of the warships. Lord Derby declared that an attempt on the part of Russia to occupy Gallipoli or the Straits would be considered a measure against England. An understanding was then (February 18) reached $(c)$, whereby Russia agreed not to occupy Gallipoli and England not to land troops. Thereupon the British vessels moved away from Prinkipo to the Gulf of Mudania. The Grand Duke Nicholas, however, informed the Porte that as the rule of the Straits was violated by the admission of English cruisers to the Sea of Marmara, it would be incumbent on Russia to occupy

(c) Ibid. p. 2670.

P. 
Constantinople temporarily; but on February 23 he assured the Sultan that he had no intention to occupy it.

Conference proposed by Austria.

Treaty of San Stefano, March, 1878.

-It was now becoming increasingly clear that the existing difficulties in the position of affairs in the near East could be solved only by a European Conference. On February 5 Count Andrassy proposed a meeting of the Great Powers at Vienna $(d)$. Prince Gortchakoff consented; but pending the preparation of the necessary preliminaries the Treaty of San Stefano (e) was signed, March 3, regardless of the interests of the other Powers. The enormous indemnity demanded (or, in default, cessions of territory), the territorial changes to be effected, and the erection of new autonomous States would have almost amounted to the extinction of Turkish power in Europe. As to the Straits, Art. XXIV. said: "The Bosphorus and the Dardanelles shall remain open in time of war as in time of peace to the merchant vessels of neutral States arriving from or bound to Russian ports. The Sublime Porte consequently engages never henceforth to establish at the ports of the Black Sea and the sea of Azof a fictitious blockade, at variance with the spirit of the Declaration signed at Paris on the 16th of April, 1856.' Art. XXIII. renewed all treaties and conventions entered into between the parties, with the exception of clauses affected by the present Act.

Warlike preparations in England and Austria.
When the provisions of the Treaty of San Stefano were communicated to England (March 23), warlike preparations began to be made. Austria, too, armed. On April 1 Lord Salisbury (who succeeded Lord Derby at the Foreign Office, March 28) issued a circular $(f)$ denouncing the treaty on the ground that it was in conflict with British interests, in contravention of existing

(d) Hertslet, p. 2668

(e) Ibid. pp. 2674-2694.

(f) Ibid. pp. 2698-2706. 
international agreements and declarations, and gave Russia an undue preponderance in the East. $\mathrm{He}$ de clared that Great Britain would take part in the pro posed Congress only on condition that the entire Treaty of San Stefano were submitted for discussion. The Imperial Chancellor replied (April 15) that Russia was willing that all the questions raised should be discussed, but he could not admit that she might be summoned before a Congress as before a tribunal and its decisions imposed on her. After several attempts had been made to settle the basis of deliberations for the Congress, the formula suggested by Bismarck was accepted, viz. that conformably to the initiative taken by the Austrian Government Germany proposed to the Powers signatory to the treaties of 1856 and 1871 to discuss the stipulations of the Treaty of San Stefano. Count Shuvaloff having declared that the Tsar had no intention to extend his conquests in Asia beyond Batoum and Kars, and in Europe beyond the limits prescribed by the Treaty of San Stefano, the British Government agreed not to contest these acquisitions. Lord Salisbury and the Russian ambassador then signed three memoranda (May $30)$ : the first specified the territorial changes accepted by Great Britain; the second, inter alia, reserved to Her Majesty's Government the right to discuss at the Congress all questions touching the Straits; the third contained a declaration of Shuvaloff as to the limits of Russian acquisitions under the Treaty of San Stefano. The second memorandum embodied, too, a declaration (which had been made on May 18 by the Russian ambassador) agreeing to accept the status quo in regard to the Straits; that is, Russia renounced the claim for the passage of the Straits by her warships.

On June 3 the German Government invited the Proposal for 
Powers to meet at Berlin $(g)$; Lord Salisbury accepted the invitation at once. On the following day a secret

Anglo- :

Turkish

Conrention.

Opening of the Congress.

Anglo-Turkish Convention of defensive alliance was signed at Constantinople (h), whereby Great Britain undertook to protect the Asiatic possessions of the Sultan if Russia acquired Batoum, Ardahan, or Kars, and the Porte agreed to introduce reforms in Asia Minor and to allow Great Britain to occupy and administer Cyprus.

On June 13 the Congress was opened at Berlin under the presidency and mediation of Bismarck, and after holding twenty sittings was closed on July 13. The deliberations consisted for the most part of a conflict between the English and the Russian plenipotentiaries. Austria and-contrary to the expectations of RussiaGermany were nearly always on the side of England; France and Italy, too, frequently supported her; so that Russia found herself isolated. Gortchakoff had felt confident he could rely on Bismarck, but he was bitterly disappointed and never forgave him for the position he took up $(i)$. 'C'est là proprement la grande trahison,' says a French writer, 'que la Russie n'a pas pardonnée et ne pardonnera sans doute pas de longtemps à l'Allemagne' $(j)$. More than once the debates became so

(g) Hertslet, p. 2721

(h) Ibid. pp. 2722, 2723.

(i) For some time after the opening of the Congress the Russian plenipotentiaries still believed that Bismarck was in their favour. Thus, Count Shuvaloff, writing to M. Giers (June 19) of the goodwill of Bismarck, said: 'You may ask me why we have not yet obtained better results with the powerful concurrence of Bismarck. It is because we are confronted with a systematic opposition from England and Austria. Andrassy, very cordial in his conversation with me, is quite different in the presence of the English, and becomes the servile admirer of every word that falls from the lips of Beaconsfield and Salisbury. The result is that Bismarck, whose great preoccupation is to avoid conflicts and bring the Congress to a satisfactory conclusion, finds it necessary to mancourre between the three, and does not show himself energetic enough in his benevolence towards us.' (Goriainow, p. 378.)

(j) A. Debidour, Histoire diplomatique de l'Europe (Paris, 1891), vol. ii. p. 517. As to Bismarck's view of Gortchakoff's hostility, see 
heated that threats were made to break up the Congress. Eventually an agreement was reached, and the conclusions, which entailed a thorough transformation of the Treaty of San Stefano, were embodied in the Treaty of Treaty of Berlin, July $13(k)$. Russia, humiliated and mortified, realised that henceforth she must yield military supremacy on the continent to Germany.

With the various Articles of the treaty we are not here particularly concerned-though the Eastern Question is of course closely connected with the Straits Question. With regard to the Bosphorus and the Dardanelles the Congress contented itself with a confirmation of the status quo. Thus, Art. LXIII. says: Status quo as 'The Treaty of Paris of March 30, 1856, as well as the Treaty of London of March 13, 1871, are maintained in all such of their provisions as are not abrogated or modified by the preceding stipulations.'

The question of the interpretation of the rule of the Straits which arose in a controversy, during the Berlin negotiations, between the British and the Russian plenipotentiaries is considered in the following chapter.

Bismarck, the Man and the Statesman, etc. (English translation), chaps. xxviii. and xxix.

(k) Hertslet, pp. 2764-2798. 


\section{CHAPTER VIII.}

\section{INTERPRETATION AND APPLICATION OF THE RULE OF} THE STRAITS.

Difficulty in THE treaty of 1871 made the interpretation of the rule interpretation of the Straits more difficult. Before then the rule was
of simpler, and was more clearly defined by the Conventions of 1841 and 1856. In 1841 the Sultan engaged to keep the Straits closed to all foreign warships; he surrendered definitively his former right of granting firmans of passage to any military flag. His sovereignty in regard to the Straits being thus restricted, it may be said that the Bosphorus and the Dardanelles were no longer his own exclusively, for the other contracting parties had a right of interference the moment he departed from his undertaking, by permitting the entrance of a foreign man-of-war. This rule of closure was confirmed in 1856.

Instances of passage of warships.
On several occasions warships were allowed to pass notwithstanding this rule. We have already seen that Prince Gortchakoff complained in his circular despatch of 1870 that the Straits Convention had frequently been violated by the signatory parties, who had thereby undermined its validity to such an extent as to give him the legal right to consider it null and void and therefore to disregard it in the future. It has also been pointed out that, according to a return laid before Parliament, there were nine instances of vessels of war (other than light vessels specially provided for by treaty) passing the Straits during a period of fifteen years; and in seven other cases questions had been raised in regard 
to applications for firmans of passage. The passage of these vessels was certainly, on a strict construction of the treaty stipulations, an infringement of the engagement, on the one hand by the Ottoman Porte for formally permitting them to enter, and on the other hand by the States to which they belonged. One or two examples may be referred to, in order to show the circumstances in which such passage was obtained by this or that Power, and the position taken up in consequence by the other Powers: the character of the Straits Convention will thus be illustrated.

In 1847, owing to a scarcity of corn in the south of French warFrance, the French Government despatched two war- 1847 . ships, the Cuvier and the Titan, to the Bosphorus, with the authorisation of the Sultan, in order to tow through the Straits merchant vessels laden with corn, and accelerate the transport to France of cargoes of cereals that had been embarked in the Black Sea ports. The Sultan delivered a firman on humanitarian grounds. A protest was none the less made by the other Powers. The Russian chargé d'affaires at Constantinople, Oustinoff, pointed out to the Ottoman Porte that the case would constitute a precedent, of which advantage might subsequently be taken by other States. This view was supported by Lord Cowley, the British ambassador, as well as by the representatives of Austria and Prussia. Accordingly, the Turkish Foreign minister requested the French ambassador, Baron de Bourqueney, to make a declaration in writing that the measure was due to conditions of urgent necessity, and that the passage of the vessels would never be invoked as a precedent $(a)$.

In 1858 the United States Government applied for U.S. warship and obtained a firman for the admission of a light war- passage, 1858. ship destined for the service of the American legation.

(a) Goriainow, pp. 292 seq. 
To the astonishment of the embassies in Constantinople a large frigate-the Wabash-arrived, carrying some fifty guns. The representatives of Great Britain, Russia and France protesting, the Turkish authorities made representations to Mr. Williams, the United States resident minister, with the result that the vessel soon left Constantinople for the Mediterranean.

Sardinian warship refused passage, 1862.

In 1862 the Sardinian Government, desiring to despatch a mission to Persia by way of the Caucasus, proposed to equip for purposes of transport from Genoa to Poti the warship Ichnusa and two gunboats. The Russian minister at Constantinople, Prince Lobanoff-Rostovsky, pointed out to the Grand Vizier that the passage of the vessels through the Straits and their presence in the Black Sea would be a contravention of the treaty of 1856 . This protest was communicated to the Sardinian Government, which was therefore obliged to abandon its project.

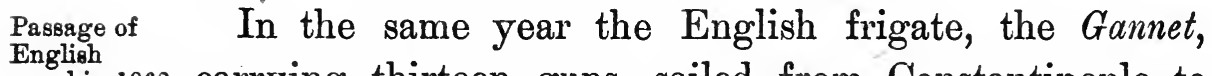
warship, 1862. carrying thirteen guns, sailed from Constantinople to Custendji with Sir H. Bulwer, the English ambassador, on board. Not only did Prince Lobanoff-Rostovsky thereupon complain to the Ottoman Government, but the Russian ambassador in London, Baron Brunnow, also brought to the notice of the Foreign Office the irregular proceeding of Sir H. Bulwer.

Russia's
attempt to Russia, so anxious about the observance of the Straits secure to Convention by other Powers, soon found that the rule passage, 1863. could be applied to herself too. In May, 1863, a unit having been withdrawn from the Black Sea fleet, the Minister of Marine wished to send as a substitute the corvette Sokol, which had before been, conformably to treaty, in the service of the Russian legation at Constantinople, and afterwards formed part of the Baltic fleet at Cronstadt. But when Baron Brunnow was instructed to ask for the necessary firman, he wrote to the 
Imperial Chancellor, Prince Gortchakoff, that the proposed passage of the vessel through the Straits would be a contravention of the principle of closing, and that the British and the French Government would be able to reproach Russia for a violation of the Treaty of Paris. In another despatch ( $b$ ) (dated October 6), the Russian ambassador reminded the Minister of Marine that the latter treaty embodied a collective engagement, and that it was not merely a question of coming to an understanding with the Porte alone for the purpose of obtaining the required authorisation. He then pointed out that the Treaty of, Paris admitted only two exceptions, first, in favour of light vessels in the service of the foreign legations in the Ottoman capital, and secondly, in favour of boats stationed on the Danube.

In 1868 the Franklin, a frigate belonging to the $\underset{\text { Passage of }}{\text { U.S. warship, }}$ United States, arrived in the Bosphorus. Whereupon ${ }^{\text {U.S68. }}$ the Ottoman Foreign minister despatched a circular Note (October 6) to the representatives of all the Powers accredited to the Porte, informing them that the Sultan intended in future to observe strictly the principle of closing the Straits to foreign warships, save light vessels sanctioned by treaty and vessels bringing sovereigns of friendly States to Constantinople.

The above examples show that the Powers signatory The treatios to the treaties of 1841 and 1856 did not consider these 1886 collecinstruments as simply comprising a number of separate and independent engagements between Turkey and each of the signatories; on the contrary, they were regarded as Acts of a collective character giving rights and obligations to each contracting party as against every other contracting party. Each was empowered to protest, and responsible for not protesting, against the contemplated passage of a foreign warship; each was entitled to

(b) Goriainow, p. 294. 
reparation, in the event of a foreign warship's passage, from the parties infringing the rule, namely, the Porte, the Government to which the said warship belonged, and also any other State that aided or abetted the commission of the prohibited act or even acquiesced in its commission.

Difficulties raised by

With the conclusion of the Treaty of London, 1871, treaty of 1871. the application of the principle of closing became more precarious, and the position of the Sultan-indeed, of the other signatories also-more difficult, owing to the removal of restrictions that had been previously imposed on him. Before 1871 the Sultan himself violated the rule of the Straits if he authorised the passage of foreign warships other than those specially provided for. But now under the treaty of 1871, though the principle of closing to foreign warships is again affirmed, the Sultan is empowered to admit vessels of war in the Bosphorus and the Dardanelles if he should deem it necessary for securing the observance of the stipulations of 1856 . The indefiniteness of the proviso and, consequently, the uncertain exercise of discretion on the part of the Sultan made the final rule of the Straits conspicuously defective, and prepared the way for international misunderstandings and conflicting views.

Passage of British warships, 1878.

During the Russo-Turkish war (1877-1878) British warships passed the Straits twice, and once without the authorisation of the Porte. This passage without a firman was declared to be a contravention of the Treaty of Paris, 1856, and the Treaty of London, 1871. The unauthorised act was, on a literal interpretation of the treaties, undoubtedly irregular; but considering the circumstances in which Turkey was at the time placed, the menace to her existence, the proximity of the Russian forces to the Ottoman capital, the danger to vital British interests, the comparative inactivity of the 
other guaranteeing signatories, the step taken by Great Britain at a critical moment in the interests of those very treaties and conformably to their essential object Justifioation. and spirit cannot be considered a culpable infraction of her engagement. Furthermore, a point of supreme importance to remember is that the Sultan was not then a sufficiently free agent to grant or refuse permission to warships in accordance with the true purport of the stipulations of 1871. The advance of the Russian arms towards Constantinople added to the insistent demands of the Tsar amounted to such duress as to deprive the Sultan of freedom of choice. Accordingly his cosignatories became entitled to intervene without any further formality in behalf of the rights and interests of Europe as laid down in the Conventions of 1856 and 1871.

The question of the interpretation of the rule of the Question of Straits prescribed by the Treaty of London came before interpretation Straits prescribed by the Theaty of London came before at Berlin
Congress, the Berlin Congress. After some discussion the repre- 1878 . sentatives of the Powers unanimously agreed to accept and confirm the existing rule as stipulated in the latter treaty. Protocol No. 14, recording the results of the deliberations arrived at during the sitting of July 6, 1878, says: 'Le président constate l'assentiment unanime de la Haute Assemblée au maintien du statu quo ante dans la question des Détroits des Dardanelles et du Bosphore' $(c)$. And this conclusion was afterwards incorporated in Art. LXIII. of the Final Act.

It is to be noted that the British delegates accepted the conclusion on the understanding that Batoum would, according to the assurances of the first Russian plenipotentiary, be converted into a free and commercial port. Lord Beaconsfield observed that, although England had desired that this fortress should remain under the Sultan's

(c) British and Foreign State Papers (1877-78), vol. 1xix. p. 1028. 
sovereignty, it would be a satisfactory solution if the port became a common centre for the commercial enterprise of all nations. Lord Salisbury afterwards declared (July 6)(d), that if Batoum were to be maintained on such conditions as would threaten the free navigation of the Black Sea, England would not have been able to engage herself 'towards the other European Powers' to forgo access to the Black Sea. Considering, however, that Batoum was declared a free and commercial port, England would not refuse to renew her engagements regarding the Straits, i.e. she would agree to the maintenance of the status quo-the principle of closing to all warships.

Now on July 8, Prince Gortchakoff asked by what means the Congress proposed to assure the due execution of its decisions $(e)$. The question was adjourned to the following session, when Gortchakoff suggested that the Powers represented should collectively guarantee the conclusions reached. But the President, Prince Bismarck, was of the opinion that each separate State could not be expected to insist by force of arms on the performance of the agreement, which-unlike the Straits Convention of 1841-did not involve a collective guarantee (ee). The point was raised at subsequent sittings without a definite result; for most of the plenipotentiaries held that the treaty, once signed, in itself constituted a guarantee of the resolutions of the Congress.

Lord

Salisbury's declaration.
As the Russian proposal for the establishment of an express collective guarantee was not accepted, Lord Salisbury made a declaration (July 11) and requested that it should be recorded in the protocol for that day (No. 18). It was as follows: 'Considering that the

(d) British and Foreign State Papors (1877-78), vol. Ixix. p. 1027.

(c) Ibid. p. 1044.

(ee) Ibid. p. 1047. 
Treaty of Berlin will modify an important part of the arrangements sanctioned by the Treaty of Paris of 1856, and that the interpretation of Art. II. of the Treaty of London, which is dependent on the Treaty of Paris, may thus become a matter of dispute, I declare on behalf of England that the obligations of Her Britannic Majesty relating to the closing of the Straits do not go further than an engagement with the Sultan to respect in this matter His Majesty's independent determinations in conformity with the spirit of existing treaties' $(f)$.

At the next sitting of the Congress (July 12) Count Sount $_{\text {Shuralof's }}$ Shuvaloff replied by requesting the insertion in the pro- countertocol (No. 19) of a counter-declaration: 'The plenipotentiaries of Russia, without being able exactly to appreciate the meaning of the proposition of the second plenipotentiary of Great Britain respecting the closing of the Straits, restrict themselves to demanding, on their part, the insertion in the protocol of the observation: that in their opinion the principle of the closing of the Straits is a European principle, and that the stipulations concluded in this respect in 1841, 1856, and 1871, confirmed at present by the Treaty of Berlin, are binding on the part of all the Powers, in accordance with the spirit and letter of the existing treaties, not only as regards the Sultan but also as regards all the Powers signatory to these transactions' $(g)$.

Lord Salisbury, in making his declaration, had assumed Apparent that, in the absence of a collective guarantee for the contradiction. execution of the Treaty of Berlin, there could not be a collective engagement in regard to the principle of closing the Straits within the limits provided by the Treaty of London. He did not, however, withdraw his consent, given on July 6, to maintain the status quo, that

(f) Ibid. p. 1070 ; Hertslet, vol. iv. p. 2727.

(g) State Papers, loc. cit. pp. 1075-6; Hertslet, loc. cit. 
is, the rules laid down in the Conventions of 1856 and 1871, which certainly implied a collective engagement. There appears, therefore, to be a contradiction between the acceptance of the status quo on July 6, and the declaration on July 11. The protocols contain no indication of any discussion on the antithetical views of the British and Russian representatives, and no pronouncement thereon was made by the Congress. (It may be added here that the undertaking of Russia in respect of Batoum, as consecrated in Art. LIX. of the Treaty of Berlin, was departed from eight years later, when, despite British protests, the port was closed and fortified.)

Lord

Salisbury's assumption doubtful.

The assumption of Lord Salisbury is certainly contrary to the established view. His interpretation has not received the support of juristic opinion. Geffcken, a leading German authority, observes of the declaration made on July 11: 'Une déclaration unilatérale insérée au protocole après coup, sans qu'il se soit produit aucune circonstance qui pourrait justifier le retrait d'un consentement donné, ne saurait altérer l'unanimité du congrès, constatée par le président, sur ce point' $(h)$. This view is shared by the French writer, Bonfils $(i)$, by the foremost Belgian international jurist of to-day, Professor Nys $(k)$, and by others. The late Professor Westlake, however, says $(l)$ : 'The distinction between engagements towards the Sultan only and those of a general European character seems to have been rather infelicitously chosen as a ground for Lord Salisbury's practical conclusion, for he had himself said at Berlin, with reference to the confirmation of the treaty of 1871 , that,

(h) Incidents de droit international dans le différend anglo-russe, in Revue de droit international (Bruxelles), vol. xvii. (1885), p. 368.

(i) Manuel de droit international public (Paris, 1912), § 503.

(k) E. Nys, Droit international (Bruxelles, 1912), vol. i. p. 509.

(l) International Law. Part I. Peace (Cambridge, 1910), p. 200. 
if Batoum had not been declared a free and commercial port, England would not have been able to engage herself towards the other European Powers to interdict herself from entering the Black Sea. But in substance Lord Salisbury was in our opinion right, for an engagement depending on the Sultan's judgment of what should be necessary in order to secure the due performance of the Treaty of Paris, towards whatever Power such engagement exists, must surely refer to the Sultan's independent judgment, and not to that which he might be made to express by pressure from some other Power.' But Lord Salisbury's declaration was not quite clear, and did not at the time necessarily imply the application of foreign pressure. A few years later, however, he expressed himself more explicitly, and to that effect.

In 1885, when war seemed imminent between Great Lord Britain and Russia in consequence of the Afghanistan Salisbury's boundary dispute, questions were raised in the House of Lords as to the entrance of the British fleet in the Dardanelles. Lord Stratheden and Campbell observed (May 7): 'The facility of operating in the Black Sea is most important to this country. It is the only area in which Russia has ever been successfully encountered by Powers wishing to restrain her. . . . If the Black Sea is closed for her advantage, Russia is entitled, by the history of the past, to deem herself invincible.... If he [the Sultan] excludes Great Britain from the Black Sea, Russia may attempt Herat with absolute impunity' $(m)$. Constantinople might also be an objective(n). After showing where Russia's most vulnerable part was, he asked whether, under existing international conventions, the Sultan was not empowered to open the Straits to every military flag.

(m) Hansard, Parliamentary Debates, 3rd series, vol. 297, cols. 1820, $1821,1822$.

(n) Ibid. col. 1824 . 
In reply, Earl Granville, the Foreign Secretary, said : 'I may mention as important that during the Conference at Berlin the noble Marquess [Lord Salisbury] declared, as is recorded in the protocols with regard to the obligations concerning the closing of the Straits, that Her Majesty's Government's obligations were limited to the engagement to respect the independent judgment of the Sultan according to the treaties in existence. Count Schouvaloff made a declaration on the following day to the effect that, in the opinion of the Russian Government's plenipotentiaries, the principle of closing the Straits is a European principle, and that the treaties concluded in that respect in 1841, 1856, and 1871, and confirmed by the Treaty of Berlin, were binding on the part of all the Powers, in accordance with the spirit and letter of the existing treaties. If I am not mistaken, I think the noble Marquess, in his despatch, explains one of his main reasons for making the statement he did; it was made in consequence of the declaration which had just taken place that Batoum should be a free port or a commercial depôt' $(0)$.

Lord Salisbury's explanatory statement was as follows : ' The object of the declaration which I had to make on behalf of Her Majesty's Government I understood to be to establish the principle that our engagements in respect of the Dardanelles were not engagements of a general European or international character, but were engagements towards the Sultan only; the practical bearing of that reservation being that if, in any circumstances, the Sultan should not be acting independently, but under pressure from some other Power, there would be no international obligation on our part to abstain from passing through the Dardanelles' $(p)$.

(o) Hansard, Parliamentary Debates, 3rd series, vol. 297, cols. 1825, 1826.

(p) Ibid. col. 1826. 
Two distinct points are to be noted in connection with Examination Lord Salisbury's declaration at Berlin. As recorded in $\begin{gathered}\text { Salisbury's } \\ \text { declaration. }\end{gathered}$ the protocol it would appear that he meant to convey that the obligation of Great Britain arose from a separate engagement between her and Turkey. It was in this sense that the plenipotentiaries of the other Powersat least those of Russia-understood him; so that the counter-declaration was inserted emphasising that Great Britain's engagement, like that of every signatory Power, was not merely several but joint. The latter is admittedly the correct view. The second point arises not from the question whether the Treaty of London, 1871 (confirmed by the Treaty of Berlin, 1878) is a collective treaty, or a series of separate treaties between the Porte and each of the Powers-that is, not from the character of the obligation-but rather from the question when the obligation under the treaty ceases altogether. A contracting party may legitimately consider a treaty abrogated on various grounds, for example, if its terms are found to be incompatible with general international law established subsequently, if events afterwards occur which make its execution physically impossible, if conditions expressly specified in it are disregarded by the co-signatories, or if implied conditions are not observed. Now under the treaty of 1871 the Sultan was entitled to admit, in the exercise of his judgment, foreign vessels into the Straits, for the purpose of ensuring the performance of certain treaty stipulations. Obviously an implied condition here is that his judgment will be exercised independently, that it will be free from external pressure. For if through the pressure of a foreign State he finds himself compelled to decide in a certain manner, such decision cannot be regarded as his at all-it is virtually the decision of the compelling State. But the treaty gives the Sultan alone, to the exclusion of every other 
State, the power to decide. In the provision that he may admit foreign warships if he thinks it necessary, there is indubitably an implied condition that his judgment is to be arrived at independently. So that if his judgment is not arrived at independently, the condition fails, and any party to the treaty may therefore consider its engagement at an end. Thus Lord Salisbury's declaration is legally sound so far as it asserts the right of Great Britain to withdraw from her engagement in case the Sultan did not act independently; but it is untenable if it implies that the engagement of Great Britain was only with the Sultan, and not with the other co-signatories. None the less, the Straits Convention as it stands (that is the treaty of 1871) lacks clearness and definiteness. If the Sultan grants a firman of passage to one Power, how will the other Powers be able to determine whether he has acted freely or in virtue of a private arrangement imposed upon him? Moreover, if he grants a firman of passage quite freely to one State, is he entitled to do so without consulting all the signatory Powers, or must he first obtain their consent, seeing that the treaty involves a collective engagement? It is manifest that owing to this obscurity the rule of the Straits needs revision. 'That it needs revision, too, on other-and more vital-grounds, revealed in the present war, will be shown later $(q)$.

New interpretation adopted by Russia, 1895.

Not long after the above-mentioned controversy, another interpretation-and this time by Russia-was applied to the Straits rule. The Treaty of London, 1871, restored to Russia the power to build and maintain a Black Sea fleet. She was not slow to take advantage of the liberty thus regained. Gradually her navy in the Euxine was augmented, and arsenals and provisioning centres were constructed. Her interests in

(q) See infra, Part III. 
the Far East having in the meantime increased, she felt that it was essential for her to be able to despatch warships out of the Black Sea through the Bosphorus and the Dardanelles for service in eastern regions. To do this it would be necessary, on her former interpretation of the treaty, to obtain not only the authorisation of the Sublime Porte, but also the consent of her co-signatories. She could scarcely hope to get the latter. Accordingly she abandoned her former view, and in 1895 declared that she would in future come to an arrangement with the Sultan alone in regard to the conditions of passage for her military flag $(\cdot)$. This declaration did not, of course, commend itself to the British Government who, foreseeing possible conflicts in the East, now insisted on the collective nature of the Treaty of London, and on the duty of Russia to obtain the concurrence of all the Powers that are parties to that Convention. State interests and State policy will always and everywhere invade the sphere of law and contractual obligations, in the absence of a supreme international tribunal empowered to settle differences between States, to restrain any attempted departure from established law and solemn engagements, and point out when a modification is desirable on the grounds of equity and right.

More recent instances $(s)$ of the passing or intended Recent passing of the Straits, and the difficulties raised thereby, instances of passing of the Straits, and the diffculties raised thereby, passage of may now be referred to.

In 1895, at the time of the Armenian massacres and the Light vessels consequent disturbances in Turkey, the Powers deemed in increased. it necessary to increase the number of the light vessels employed in the service of their respective legations at Constantinople for the purpose of ensuring the safety of

(r) Revue générale de droit international public (Paris, 1903), p. 333, n. 3 .

(s) Cf. M. Lozé, La question des Détroits (Paris, 1908), pp. 73 seq. 
their subjects resident in the Ottoman capital. Accordingly the ambassadors of the six Powers asked the Porte to authorise the passage of these vessels and admit them in the Golden Horn. The Sultan, conformably to his inveterate dilatory and temporising tactics, raised objections de facto rather than de jure, which caused prolonged pourparlers $(t)$. Eventually he issued an irade (December 10, 1895), permitting the doubling of the number of light vessels, subject to three conditions: (1) the vessels in question were to be only light vessels in accordance with the recognised limits as to size and tonnage; (2) they were to enter the Golden Horn successively at certain intervals; (3) the authorisation was to be only temporary and provisional. The first condition was in conformity with Art. II. of the Treaty of London, the second was intended to prevent the Turkish population in Constantinople from concluding that there was to be a naval demonstration by the Powers, and the third was designed to spare the amourpropre of the Sultan. Firmans were then granted, and about the middle of December each Power, except Germany, sent an additional light vessel to the Straits. In this case the Powers acted together and in agreement. At first Great Britain, having regard to the dangerous state of the Turkish capital and to the necessity for taking immediate steps to safeguard her interests and subjects there, was preparing to act independently of the other Governments; she had a powerful squadron at Salonica ready to proceed to Constantinople. Austria and Italy were ready to follow the example. The ambassadors of Russia, France, and Germany urged that such action would result in a general conflagration; and Prince Lobanoff declared (November 16) that Russia

( $t$ ) Cf. Revue générale de droit international public (Paris), vol. iii. (1896), pp. 372 seq. 
would not acquiesce in Great Britain's separate naval operations, and threatened that the Black Sea fleet was ready to sail at the word of command and would be in the Bosphorus in thirty-six hours. Thus the conjoint action afterwards agreed upon prevented a conflict between the Powers.

About the same time the United States Government Efforts of endeavoured to obtain permi ion for the passage of a to prod States endeavoured to obtain permission for the passage of a to procure vessel to Constantinople. The application made (No- warship. vember, 1895) by Mr. 'Terrell, the American minister, on behalf of the U.S.S. Marblehead, was refused by the Sultan, who said that other Powers not parties to the Straits Convention would take advantage of such a precedent and would seek to obtain admission for their warships $(u)$. Shortly afterwards the United States sought authorisation to station a light vessel at Constantinople. Mr. 'Terrell obtained the views of the ambassadors in the Ottoman capital ; most of them were either in favour of the admission or did not object to it, but the Russian representative strongly opposed it. Mr. Terrell argued that Art. II. of the first annex to the Treaty of Paris, 1856, confirmed by the 'T'reaty of London, 1871, empowered the Sultan to admit light vessels of friendly States, whereas Art. III. entitled the signatory parties to station light vessels in the mouths of the Danube. This difference of expression, he urged, must correspond to a difference in the rights established; whence it followed that all friendly Powers were accorded the right to send a light vessel to Constantinople. In reply, the Russian ambassador pointed out that such results did not follow from the differences in the phraseology; for the treaty says that the Sultan reserves a

(u) Mr. Terrell, minister to Turkey, to Mr. Olney, Secretary of State, November 21 and December 6, 1895: Foreign relations of the United States (1895), vol. ii. pp. 1344, 1383 ; J. B. Moore, Digest of international law, vol. i. p. 668. 
right to himself 'as in the past' to deliver firmans to light vessels employed 'as is customary' in the service of the legations of friendly Powers. 'Thus the existing practice was merely confirmed, in regard only to the signatory parties, who did not include the United States. American warships were accordingly excluded from the Straits, in pursuance of the Russian contention, which was justifiable under the existing treaties; the United States. Government acquiesced, but has refused to recognise the legal validity of the rule. The reason for the exclusion was explained by the Turkish minister at Washington in his communication to the Secretary of State: 'His excellency 'Tevfik Pasha has just informed me that the Sublime Porte regrets that it cannot comply with Mr. Terrell's request for permission for the Buncroft to pass through the Strait, that vessel having been authorised to remain at the disposal of the United States legation at Constantinople. Your excellency knows perfectly well the earnest and sincere desire of the Imperial Government to do all in its power to strengthen if possible the ties of friendship which unite the two countries, but in this case a certain fact is involved, to wit, that only the signatory Powers of the Treaty of Paris enjoy the right to have vessels of war permanently at Constantinople at the orders of their respective embassies. Now, the United States Government does not appear in the number of the signatories of that treaty. I am, consequently, sure that your excellency will be pleased to take the foregoing into consideration' $(x)$.

Attempt of Greece to secure passage.
A little later a similar question arose in regard to Greece. The Greek Government, desiring to despatch a light vessel to Constantinople for the purpose of pro-

(x) Mavroyeni Bey, Turkish minister, to Mr. Olney, Secretary of State, June 16, 1896: Foreign relations of the United States (1896), vol. ii. p. 1461 ; Moore, Digest, vol. i. p. 668. 
tecting the interests of its subjects there, consulted in the first place the ambassadors of the .Powers. The latter replied that the resources of a light vessel would be totally inadequate for safeguarding the Greek colony, and that the despatch of a large warship would raise considerable difficulties.

In 1897, during the troubles in Crete, Russia desirous Passage of of participating in the collective intervention of the troops with Powers asked the Sultan for permission to send troops Fowers, 1897. through the Straits. 'Thus on March 16, 1897, Comte de Montebello, the French ambassador at St. Petersburg, wrote to M. Hanotaux, the Foreign minister: 'Des ordres sont donnés aux autorités navales et militaires pour l'embarquement immédiat de six cents hommes. L'autorisation du Sultan est accordée pour le passage des Détroits' $(y)$. 'The authorisation, however, was granted only after the consent of the other Powers had been obtained.

The following year the Bulgarian Government applied Passage of to the Sublime Porte for permission to send through the gulgarian Straits from the Mediterranean to the Black Sea a gunboat intended to protect the Bulgarian coast. The question of passage was here more than usually complicated by the fact that Bulgaria was a vassal State of Turkey. The Porte maintained that Bulgaria was not entitled to possess warships apart from the Ottoman fleet; but it appears that the Powers, having been consulted, thought otherwise, for towards the end of the year the gunboat was allowed to pass the Straits.

In September, 1902, the Russian Government asked Russian the Porte to permit the passage of four torpedo-boats to pass, 1902. the Black Sea, where the 'Tsar was to review his southern fleet during his stay at Livadia. After various

(y) Iivre jaune français. Affaires de Crete ; 'février-mai, 1897, No. 326, p. 177. 
difficulties arising in the course of the negotiations had been smoothed over, the Sultan issued an irade on these conditions: (1) the torpedo-boats were not to carry armament or a war crew ; (2) they were to fly the commercial flag; $(3)$ they were to pass at intervals of at least twenty-four hours; (4) they were to comply with all the formalities observed by merchantmen. These conditions having been fulfilled the vessels passed the Dardanelles and the Bosphorus and joined the Black Sea fleet.

Arrangement without con parties.

In this case the arrangement was made between Russia and Turkey alone; their co-signatories were not consulted, as they had been previously. Such a departure did not remain unchallenged; for some four months later (January 6, 1903) Sir Nicholas O'Connor, the British ambassador at Constantinople, protested to the Sublime Porte against the authorisation granted to the Russian warships, on the ground that it was an infringement of treaty stipulations; and he declared that England would demand a like privilege when an occasion arose. The English press was at once up in arms, reproaching Russia and threatening the Sultan. The other Powers appeared to be little disturbed, and did not give their adhesion to the British Note. Whether they were becoming indifferent to the application of the rule of the Straits, or bewildered at the vicissitudes in its interpretation, it is difficult to say. The German papers took advantage of the incident to attack Lord Salisbury's policy; and the British claims were described as ' ridiculous.' 'The Times concluded (January 6, 1903) that, in the case of differences with Russia, Great Britain must be prepared to see Germany take the side of Russia. 'The Standard (of the same date) reminded Germany of her signature to the Declaration of London which proclaimed the inviolability of treaties, and of her 
signature to the Treaty of London which expressly maintained the principle of closing the Straits to all warships; and observed that if she thought she could no longer concern herself with the Dardanelles, other Powers might adopt a similar policy of abstention in regard to such subjects as closely affected her. The Daily T'elegraph observed that the French proverb which said a door must be either open or closed applied to the question at issue: if the Dardanelles were to be opened to the Russian warships, they must not be closed to the British military flag.

However this may be, Russia had gained a diplomatic Altered views victory at Constantinople, which showed that her influ- of Gritain and ence there was increasing. But it is doubtful whether Russia. she would have been so successful had German opposition been added to the British. For in point of fact the predominating Power in Turkey at that time was neither Great Britain nor Russia, but Germany. A French writer points out that the real reason for Russia's securing the passage of the four torpedo-boats was not merely to augment the Black Sea forces, but on the one hand to show her restored influence with the Sublime Porte, and on the other to regard the authorisation as a precedent for supporting subsequent claims in respect of the passage of the Black Sea fleet through the Straits into the Mediterranean in the event of its being required for service in the Far East (z). But the most significant

(z) 'La mauvaise humeur agressive de la presse anglaise, le ton rogue et hautain des journaux allemands nous révèlent plus sûrement que les communications officielles des chancelleries les raisons véritables et, s'il était permis d'employer cette expression, les 'dessous' de l'incident des quatre torpilleurs. On peut croire que ce n'est pas dans le seul dessein d'augmenter de quelques faibles unités la flotte de la Mer Noire que le gouvernement du Tsar s'est résolu à faire, auprès du Sultan, une démarche diplomatique de cette importance; il a voulu, sans doute, donner la mesure de l'influence que la Russie avait su reconquérir à Constantinople ot peut-être créer un précédent ou tenter une expérience pour le cas où sa flotte de la Mer Noire 
point in the affair is the change of front adopted both by Great Britain and Russia. Lord Salisbury declared at Berlin that the British engagement in regard to the Straits was only with the Sultan, and implied no obligation towards the other signatory Powers. On the contrary, Count Shuvaloff emphasised that the rule of the Straits was based on a joint engagement of the Powers, who were all entitled to take cognizance of any case of passage. Now Great Britain held what Russia had before maintained, and Russia held what Great Britain had before maintained. 'Ainsi, par un étrange chassé-croisé, la Russie et l'Angleterre abandonnaient simultanément l'interprétation que leurs plénipotentiaires avaient respectivement défendue au Congrès de Berlin: la Russie reconnaissait au Sultan le droit d'accorder le passage sans avoir à en rendre compte à qui que ce soit; l'Angleterre le lui déniait' $(a)$.

The Straits question in the RussoJapanese War.

During the Russo-Japanese War the question of the Straits was raised once more, and this time in circumstances that were most poignant for Russia, and alarming to other Powers by reason of the various issues involved. Early in July, 1904, the Peterburg and the Smolensk, two vessels belonging to the Russian Volunteer Fleet $(b)$ in the Black Sea, were disguised as merchantmen and

aurait intérêt à pénétrer dans la Méditerranée ou serait appelée en Extrême-Orient.' (R. Pinon, Revue des deux mondes, Oct. 1905, p. 819.)

(a) Ibid.pp. 818, 819.

(b) The Russian Volunteer Navy was established during the RussoTurkish War, 18:7-1878, at the instance of a patriotic association, when hostilities with Great Britain seemed imminent. The ships of this fleet carry the mercantile flag in time of peace and may engage in commerce, though they are usually employed in the public service as transports between the Black Sea and the Russian possessions in the Far East. Their crews are subject to naval discipline and training, and the two principal officers of each vessel are commissioned by the Government. In 1900 they took part in the Chinese expedition despatched by the Powers as a result of the revolt of the Boxers. (Cf. C. Roux, La marine marchande russe, in Revue des deux mondes (Paris), Sept. 15, 1904, pp. 348 seq.) 
despatched through the Bosphorus and the Dardanelles into the Mediterranean, and thence proceeded through the Suez Canal into the Red Sea. They carried the mercantile flag and declared themselves merchant ships on entering the Straits and the Canal. Now in order to obviate difficulties a special agreement was entered into between Russia and Turkey in 1891, wherein it was stipulated that vessels of the Volunteer Fleet should not be permitted to pass the Straits any more than warships, if they carried armament or munitions of war. The Peterburg and the Smolensk, however, though flying the commercial flag, carried armament, munitions of war, and fighting crews; and after leaving Suez they revealed their true character and began to exercise belligerent rights over neutral shipping. Several vessels were seized by them on the charge of carrying contraband. Amongst them was the British mail steamer the Malacca, the news of whose capture (July 13) aroused great excitement in England. The British Government protested against the act, and declared that if the capturing vessels were commissioned warships, Russia had violated the treaties relative to the Straits in failing to obtain the necessary authorisation for the passage; but if they were merchantmen, she had infringed a fundamental principle of international law which restricts belligerent operations to lawfully commissioned warships. Thereupon the commissions of the two vessels were revoked, and reparation was eventually made $(c)$.

Later, the Russian Government, desirous of sending to Admiral Rodjetswenski's fleet in the Pacific seven vessels of the Volunteer fleet which were lying at Odessa

(c) See T. J. Lawrence, War and neutrality in the Far East, 2nd ed. (London, 1904), pp. 200-218; Sir F. E. Smith and N. W. Sibley, International law as interpreted during the Russo-Japanese War (London, 1905), pp. 40 seq. Cf. Hansard, Parliamentary Debates (1904), 4th series, vol. cxxxviii. pp. 1433, 1479. 
laden with coal, applied to the Porte for authorisation. It was granted subject to certain conditions, which, however, Russia neither agreed to accept nor in fact fulfilled.

Russia's difficult position.
The rule of the Straits thus proved to be a powerful ally of Japan. The best squadron of Russia found itself imprisoned in the Black Sea in her hour of need; and so she was fatally handicapped throughout the war. No wonder, then, that Russians have clamoured for the abrogation of a rule which is in their eyes arbitrary and obnoxious. Moreover, in regard to the Peterburg and the Smolensk, they did not consider as justifiable the British objection to the passage through the Straits. The leading Russian newspaper, the Novoye Vremya $(d)$, pointed out that the rules restricting the passage of warships were established only in the interests of Turkey, and not in the interests of foreign Powers engaged in hostilities amongst themselves. The writer held, too, that the passage of the cruisers through the Straits had nothing in common with their subsequent operations, that at the time of their passage they were not cruisers at all, and that an intention to become converted in case of necessity did not deprive them of their commercial character before their actual conversion. It is true that the Straits rule was established primarily in the interests of the Ottoman Empire; but it is equally true that it was established, secondarily, in the interests of other contracting Powers. Furthermore, the treaty of 1871 reserved to the Sultan alone the power of authorising or denying the admission of warships. 'The contention that the Peterburg and the Smolensk did not contravene any rule of international law then in force will be considered presently.

(d) The article was reproduced in a French translation in Questions diplomatiques et coloniales (Paris), Aug. 1, 1904, pp. 191-193. 
Again, in 1905, the factitious and unsatisfactory Incident of character of the stipulations as to the Straits was shown Potemkin in the case of the incident of the Kniaz Potemkin. This 1905. was a Russian cruiser of the Black Sea, whose crew mutinied during the then existing revolutionary movement in Russia, and eventually carried her to Constanza and surrendered her to the Roumanian authorities, who restored her to the Russian Government. The vessel did not reach the Bosphorus; but had she passed, the Russian Government could have been held responsible, and if no damage had been done by her, what reparation would have been demanded from Russia? The diffculties involved in the application of the Straits rule were thus becoming increasingly manifest. '. . . . L'approche du cuirassé avait réveillé,' says a writer already quoted, "cette "question des Détroits," qui est l'une des formes les plus dangereuses de cette maladie chronique de l'Europe moderne que l'on appelle la "question d'Orient." . . . Les chancelleries se souvinrent quẹ le régime des Détroits si souvent fixé, changé et remanié par des traités successifs, remis en cause en 1902 et en 1904 par des incidens significatifs, restait en définitive mal déterminé' $(e)$.

In 1912, during the Turco-Italian War, Turkey laid Turoo-Italian mines in the Dardanelles to prevent the approach of the Italian fleet. She was entitled to deny access to foreign warships; but foreign merchantmen possessed the right of navigation in the Straits both under the general principles of international maritime law and under the dispositions of various treaties. Owing to remonstrances from neutral States, the Porte was obliged to remove the mines and open the Dardanelles to neutral commerce.

(e) Pinon, loc. cit. pp. 801, 802. 
The first Balkan War.

Passage of the Goeben and the Breslau.
During the first Balkan War, the Powers, fearing an outburst of Mussulman fanaticism in Constantinople as against the Christian population in consequence of the Turkish defeats, applied for and obtained permission to send a cruiser each to the Ottoman capital (November, 1912). (In this case not only were the signatory parties to the Straits treaties authorised to despatch warships, but also the non-signatory States, Spain, Holland, and Roumania.) The passage was thus secured as a result of a collective understanding between the Powers on the one part and the Porte on the other. A proviso was attached to the authorisation to the effect that the fact of passing the Straits should be deemed to be exceptional, and should not affect their status.

Finally, the Straits question came into prominence agrain at the very beginning of the present Great $W a r(f)$. The Ottoman Porte, in allowing the German warships, the Goeben and the Breslau, to pass the Dardanelles (August 10, 1914), and commit acts of war in Turkish territorial waters, violated not only the Straits. Conventions but also the duties of neutrality imposed by the Hague Conventions and international law in general. The French ambassador at Constantinople protesting (August 17) against these breaches of written engagements and of common law, the Porte expressed its regret, acknowledged the non-fulfilment of its legal obligations, and begged the French Government to consider the 'deplorable incident' as closed. 'The British ambassador, too, pointed out (October 4) that the neutrality regulations which the Porte had itself drawn up and promulgated were not observed by it $(g)$. Among

(f) Cf. C. Phillipson, International Law and the Great War (London, 1915), pp. 289 seq.

(g) Ibid. pp. 292 seq. 
these, for example, rule 13 recognised that the status of the Straits was governed by international treaties; despite this public declaration, foreign warships were allowed to enter, to use Ottoman waters as a base for naval operations, and to engage in overt hostilities, mines were permitted to be laid at the entrance to the Straits, and the free passage of British merchantmen was interfered with by Turkish authorities.

Whatever political or territorial changes are effected at the conclusion of the present war, the régime of the Straits imperatively demands a total reconstruction. Schemes that have been suggested therefor will be considered in a subsequent chapter $(h)$.

We have throughout spoken of the exclusion of war- What ressels ships from the Straits and of the admission of merchantare warships.

men. But more than once-and notably in the RussoJapanese War-the question has arisen as to what the line of demarcation is between the two classes of vessels. The naval forces of a State usually include two kinds of ressels: (1) fighting vessels ('vaisseaux de combat'), comprising battleships, cruisers, destroyers, torpedo boats, and submarines; and (2) auxiliary vessels ('vaisseaux auxiliaires'), comprising transports, despatch boats, colliers, repairing ships, supply ships, etc. At the second Hague Conference, 1907, Lord Reay proposed, on behalf of Great Britain, that this classification should receive formal recognition; but his proposal was afterwards abandoned, on the ground that the assimilation of the status of auxiliary vessels to that of fighting ships involved the principles of 'unneutral service.' But all these vessels, whether destined for actual fighting or for performing public services connected with hostilities, are

(h) See Part III. Chaps. III. and IV. 
alike subject to attack and destruction by the enemy. From the point of view, however, of the passage of the Straits, a distinction is necessary. The fundamental object of the rule of the Straits was, in the earliest as in the latest treaty, to protect Turkey by making it impossible for a foreign warship to come up to Constantinople and bombard the town. Therefore a vessel flying a mercantile flag, carrying a commercial crew, and possessing no armament, could not be considered a warship for the purpose of passing the Dardanelles and the Bosphorus. Her intention to become converted elsewhere in order to engage in belligerent operations not affecting Turkey was a question that could not properly concern the Porte. But having once passed and become converted, she could be afterwards excluded. Similarly, an armed vessel carrying a nilitary crew should not be considered a warship, within the meaning of the rule, if her royage was obviously not undertaken for belligerent purposes; e.g. the cruisers or armed yachts carrying sovereigns on their friendly visits to foreign Powers, or carrying ambassadors on their diplomatic service. Thus, in regard to the passage of the Austrian warship that had brought the Emperor to Constantinople in 1868, the Austrian Chancellor in a Note, December 22, 1870, rightly claimed that warships exclusively employed in connection with royal visits were for the time being deprived of their military status $(i)$. However this may be, in 1871 the Sultan became the sole judge as to the existence of any danger to his country, and therefore as to the expediency of admitting foreign warships in the Straits; but this régime proved no more satisfactory than the preceding, because, in the first place, it depended on the arbitrary discretion of the Sultan, and

(i) Staatsarchiv, vol. xx. No. 4239. 
secondly it facilitated diplomatic intrigues at Constantinople and promoted a most insalutary competition of the Powers for the attainment of supremacy in the counsels of the Porte. Thus a convention that was intended to compose the differences of the Powers only aroused their jealousy and hostility, and has brought nothing but trouble. 


\section{PAR'T III.}

\section{Reconstruction.}

\section{$\rightarrow$ \\ CHAPTER I.}

THE ATTITUDE OF RUSSIA DURING THE NINETEENTH CENTURY.

Varying Russian views.

The ' sick man' theory, 1800.

Policy of Alexander I.

BEFore we examine suggested schemes of reconstruction in regard to the Straits, it is necessary to consider Russia's changing attitude-real or apparent-towards the question. This chapter, will, therefore, on the one hand be supplementary to the preceding exposition, and, on the other hand, will serve as an indispensable preliminary to a right understanding of the present régime as well as to a due appreciation of proposed substitutes. Already in 1800, as we have seen $(a)$, the Eastern Question was a source of anxiety and disturbance in Europe. Count Rostopchin then declared that, in the interests of general peace, it was essential to effect a dismemberment of the Turkish Empire, which was an invalid past recovery. This was the true 'national' policy of Russia; and she must take care to get the best slice in the eventual partition. Paul I. shared this view, and in order to carry it out entered into an alliance with France as against England (1801).

Alexander I., however, thought it safer for his country to keep on good terms with England. Soon after his accession, Kotchoubey laid a memorandum before him (1802) in which he urged that the best course

(a) See supra, p. 33. 
for Russia was to maintain the Turkish Empire in its weak state, and do everything possible to prevent its complete dismemberment. In the Franco-Russian negotiations of $1807-1808(b)$, Rumiantseff declared that his master did not desire territorial aggrandisement; and when the dissolution of Turkey was discussed, the Tsar suggested that Constantinople should be made a free town. But the very next day his foreign minister said that Russia must have the Bosphorus and the Dardanelles as well as Constantinople. It was thus the intention of Alexander to transform the Black Sea into a Russian lake, and to acquire exclusive possession of the entrances thereto. He was unable to come to an agreement with Napoleon, who wanted the Dardanelles so that the Mediterranean might be made a French lake.

In 1815 the Tsar, refusing to recognise Turkey as a member of the family of nations, deliberately excluded her from the Holy Alliance. Aggrandisement at the expense of the Sultan was probably not far from his thoughts then.

Under Nicholas I. a complete change of policy is Policy as to apparent. During the negotiation of the Peace of weak Turkey, Adrianople (1829), the secret committee for Eastern 1829. affairs, having examined the nature of Russo-Turkish relationships in the preceding quarter of a century, came to the conclusion that it was really in the interests of Russia to prevent the dissolution of Turkey, and that it was advantageous to have a weak State as a neighbour, but that the Straits must not be allowed to fall into the hands of any Power whatever. When Orloff was appointed ambassador at Constantinople (1833), he was instructed to make every endeavour to combat French influence, to gain the confidence of the Sultan, to assure him that it was the aim of the Tsar to preserve

(b) See supra, p. 41. 
Turkey, and that his safety depended on the generous support of Russia. The Treaty of Unkiar-Skelessi, July 8, 1833, was a diplomatic triumph for the new ambassador. By the Convention of Münchengrätz, September 18, 1833, Nesselrode and Metternich agreed to unite their efforts for the preservation of the Ottoman Empire, and, in case it were dissolved, to act together in the establishment of the new régime.

Brunnow's declaration, 1839.

The 'sick man' theory again, 1853.
In 1839 Baron Brunnow suggested to Lord Palmerston that the Straits should be permanently closed to warships, and explained that the object of Russia in concluding the Treaty of Unkiar-Skelessi was to ensure the safety of Turkey. He said that the Emperor did not intend to acquire a protectorate over the Sultan's dominions, or to keep a door open for himself and closed for others.

Deolaration of A few years later (1844) Nicholas visited London.
Nicholas I. and his minister.

In his conversations with Prince Albert and the British ministers, he repeatedly declared that his policy was to maintain the status quo in the Ottoman Empire. Soon afterwards, Count Nesselrode, referring to this declaration of Russian policy, modified in a significant manner the Tsar's pronouncement: he reminded Lord Aberdeen that in the opinion of Russia Turkey was a 'sick man,' so that it was well to prepare for the inevitable decease; he then suggested that an Anglo-Russian understanding should be reached on the subject. In these circumstances the motives of Russia were not above suspicion.

The 'sick man' theory was brought forward once more by Nicholas in a noteworthy interview (January, 1853) with Sir Hamilton Seymour, the British ambassador at St. Petersburg. He pointed out that arrangements should be made in regard to the succession, and suggested a partition scheme whereby neither Russia nor England should acquire permanent possession of Constantinople. Her Majesty's Government, however, 
differed as to the imminence of Turkey's dissolution, and maintained that if external intervention in Turkish affairs became necessary it should proceed from the conjoint action of the Powers. Immediately afterwards the Russian minister endeavoured to undo the effect caused by the Tsar's observations.

In 1855, during the negotiations at Vienna for the Gortchakof's termination of the Crimean War, Prince Gortchakoff 1855. proposed that the warships of all nations should have the right of passage in the Straits.

The Crimean War proved disastrous to Russia, and Russia's the Treaty of Paris struck her Eastern ambitions a hard Policy after blow. Henceforth she was resolved to retrieve her position. Her experience in the war had shown her how desirable it was for her to be able to command the Straits in the case of a future war with a maritime Power. To many minds in Russia it became clear that Constantinople must be definitively and uncompromisingly the objective of her Eastern policy. The most powerful advocate of this policy was Ignatieff, one of Ignatief's the ablest ambassadors the Tsar ever sent to. Turkey. He fully realised the opposition Russia would inevitably meet with, especially from Great Britain and Austria. He was of the opinion, however, that the establishment of an Anglo-Russian entente, assuring to Great Britain her interests in Egypt and the route to India, might be the means of removing British opposition. He writes to this effect in a letter dated December 23, 1866 : 'Every time the question of the partition of Turkey comes up two fundamental obstacles arise from Europe: the fate of Constantinople, and the question of Egypt; and every time our adversaries profit by the exaggerated apprehensions produced by the Russian claims in order to concentrate at once thereon all the passions and all the jealousies of the Great Powers, and to turn European 
public opinion against us. We must henceforth distract the attention of Great Britain from Constantinople by co-operating with her in all that concerns the route to India. That is the direction in which our diplomatic art must be adjusted. It would be desirable to produce a collision of European interests in Egypt, in order that the whole question of the régime of the Straits may seem to Europe of secondary importance; and once Egypt is assured to England, the latter would no longer oppose our projects in the East' $(c)$. Ten years later he argued, in a letter addressed to the Tsar (July, 1876), against making Constantinople a free town, and for its occupation by Russia: 'To make Constantinople a free town would be impossible. The diversity of its population, the antagonism of races, the great number of villages situated on both shores of the Bosphorus would be opposed to the introduction of a homogeneous and autonomous administration implied in a free town. Moreover, it would not be advantageous for Russia that Constantinople, if made a free town, should be occupied by a European garrison, for she would find herself, ipso facto, under the continual menace of the Power that would possess maritime supremacy. It is therefore necessary that Russia should militarily occupy TsarGrad [Constantinople], and possess besides a naval station in the Dardanelles, and the fortresses of the Asiatic and European shores. Russia cannot and must not allow anyone to dominate the access from the Mediterranean to the Black Sea, and the possession of Constantinople is the supreme goal of her efforts whatever be the régime that exists temporarily through the force of circumstances' $(d)$.

(c) Quoted (in French) by M. Hoschiller, L'Europe devant Constantinople (Paris, 1916), pp. 10, 11.

(d) Ibid. p. 10. 
In the negotiations during the Russo-Turkish War, Russia's 1877-1878, Russia tried hard-but in vain-to modify $1877-8$. the rule of the Straits so that foreign warships should continue to be excluded therefrom, whilst Russia should be enabled to secure the passage for her own warships only by means of an arrangement with the Sultan.

In the meantime the panslav movement was extending. The panalar The leanings and aspirations of influential circles in Russia in regard to Constantinople and the Straits were strikingly accentuated thereby. A great stimulating influence was exercised by a work entitled Russia and Europe (e), whose author, N. J. Danilewsky, had occupied various official positions, though none of great importance. The substance was first published in the form of articles in 1869 in a review (Zaria), and in volume form it appeared in 1871 under the auspices of the 'Society of Public Utility,' which was supported by the Government. The third edition was issued in March, 1888, and was sold out by October in the same year; further editions followed. The editor of the fourth edition (1889), M. Strachov, designates the author the 'slavophil par excellence,' and his book ' the complete catechism and code of slavophilism.' Before 1870 panslav ideas were sporadic ; after that date they became more systematised and widespread, penetrated political circles, and were absorbed into national policy. Nationalism was set up against western civilization, which was held in contempt. The slavophils were really actuated by a religious impulse; they were confident that the Orthodox Church had preserved the Russian people in its pristine virtue, and now called upon it to bring the light to the western nations. To many Russians, who cast longing eyes on

(e) There does not appear to be an English translation of the book, but there is a convenient summary in Firench (to which the present writer is indebted) by J. J. Skupiewski, La doctrine panslaviste (Bucarest, 1890). 
Constantinople-their future Tsargrad-the acquisition of the Ottoman capital was not intended to satisfy imperial needs or imperial ambitions; Constantinople was to be, rather, the metropolis of orthodoxy. Thus Dostoievsky observes:- 'Tsargrad must belong to us, not as capital of Russia, not as metropolis of a panslav federation, not as port, not because Russia needs to emerge from the four walls in which she is imprisoned and which have become too narrow, in order to enjoy the air of the seas and oceans, but in the name of moral right. Russia must demand Constantinople as the head of the orthodox faith' $(f)$.

Another aspect of the conflict between Russian nationalism and western ideals is seen in the teaching of Pobiedonostseff $(g)$, the Procurator of the Holy Synod and the uncompromising champion of autocracy and orthodoxy. He believed that Europe, with its parliaments, its press, its systems of popular education and legislation, is a 'solemn warning to unspoilt Russia' $(h)$, that the diseases and dissolvent forces inseparable from western civilization can be kept out of the Tsar's empire by the promotion of absolutism, officialism, and the orthodox religion.

Danilewsky's exposition of the panslav doctrine.
Let us look more closely at the doctrine set forth by Danilewsky. Conquest, he says, is a political assassination, or at least a crime resulting in the mutilation of the organism of a nation (i). Every nationality has the right to its own independent existence, so long as it manifests a consciousness of that existence and aspires to it $(k)$. The wars Russia has waged have been of a

(f) Quoted by Hoschiller, op. cit. pp. 14, 15.

(g) Cf. his Reflections of a Russian Statesman, English translation (London, 1898).

(h) Cambridge Modern History, vol. xii. (1910), p. 314.

(i) Skupiewski, op. cit. p. 9.

(k) Ibid.p. 10. 
defensive character. In the case of nations lacking in culture the question of conquest does not arise. The Eastern Question must be settled by armed conflict, for it cannot be settled by diplomacy $(l)$. At bottom the conflict will be, not between Europe and Asia, but between the Greek and the Roman types of civilization: Germano-Roman culture as against Slav civilization, which is the heir of Byzantine culture $(m)$. Europe protects Turkey, and uses her as an instrument in the struggle against Russia $(n)$. The partition of the Ottoman Empire between Russia and Austria would be contrary to Slav interests. The cession to Austria of the smallest portion of Slav territory would be a crime against Slavism. Such a crime was committed at the Congress of Berlin; the acceptance by Russia of the Berlin decision amounted to a 'Berlin treason' $(o)$. It is doubtful, indeed, whether Russia really ever wanted to annex Turkey.

The only solution of the Eastern Question, Danilewsky emphasises, lies in the establishment of a Slav federation, which would eventually incorporate various non-Slav elements, e.g. Greeks, Roumanians, Hungarians $(p)$. To this Slav federation Constantinople is indispensable $(q)$. It is not only a city of the past, but also a city of the future; it will arise again, like the phœnix from its ashes, and will ever be reinvigorated with new vitality; and its name will be Tsargrad $(r)$. As it was taken from the Greeks, it ought to be restored to them as the legitimate heirs. But the true heirs are dead $(s)$.

(l) Ibid. p. 73 .

(m) Ibid.p. 75 .

(n) Ibid. p. 78.

(o) Ibid. p. 79.

(p) Ibid.p. 87

(q) Ibid. pp. 89, 90.

(r) Ibid. p. 91.

(s) Ibid. p. 92. 
The 'historic rights' of Greece or of any other nation are of no value. Therefore Constantinople is now a res nullius, which must, however, belong to the people whose ideal now represents that of ancient Byzantium, viz. Russia $(t)$. Turkey has not been able to maintain herself on the Bosphorus; much less will Greece, a smaller State, be able to do so. If Russia cannot by force prevent Constantinople from falling into the hands of Greece, she must resort to intrigues $(u)$.

The only Powers that can claim to possess Constantinople are Austria, France, England, and RussiaGermany has no interest whatever in the Bosphorus. Austria could only take possession of it by transforming herself into a Slav federation-which she cannot do. England and France have no direct interest in the possession of Constantinople; the only advantage to them would be to paralyse the normal development of Russian power-they would thereby gain the right to dig a knife in the living flesh of Russia $(x)$. But this would prove a great disadvantage to the possessor, who would always have to be on guard against Russia and maintain a large army and fleet in the Bosphorus. Thus the acquisition of Constantinople by any other State but Russia would be either unjust or impossible $(y)$. It is Russia alone that would derive real benefits from the possession, e.g. (1) the security of her southern frontiers would be assured; (2) it would not be a burden on Russia as on other Powers, for the costly and difficult defence of the long line of southern frontiers would be reduced to the defence of a single point very easy to protect owing to its strategic position; (3) Russia would then be enabled to create a fleet-for a great and extensive country

(t) Skupiewski, p. 94.

(u) Ibid. p. 95.

(x) Ibid. p. 96.

(y) Ibid. pp. 97, 98. 
cannot remain purely continental-and dominate the Black Sea ; (4) from Constantinople she could exercise and consolidate her influence in the East $(z)$.

But, concludes the apostle of panslavism, if we look more deeply into the question, we shall find that the direct annexation of Constantinople and the surrounding district to Russia would make the city a dangerous rival of several Russian towns, such as St. Petersburg and Moscow. Now these cities must retain their position, and continue to occupy the first place in the State: Moscow must ever remain the true capital of Russia and the centre of Russian life. Hence Constantinople must be made the capital only of the panslav federation (a).

That this panslar movement has found itself opposed, in recent years, to western tendencies, and that the widely growing desire for Constantinople and the Straits has met with strong opposition from leaders of thought in Russia, we shall see in the following chapter.

(z) Ibid. p. 100.

(a) Ibid. pp. 101, 102. 


\section{CHAPTER II.}

RECENT EFFORTS OF THE RUSSIAN GOVERNMENT TO MODIFY THE RULE OF THE STRAITS-ATTITUDE OF THE POWERS -DEVELOPMENT OF OPINION IN RUSSIA-SCHEMES FOR RECONSTRUCTION SUGGESTED - INFLUENCE OF THE PRESENT WAR. Recent efforts IN recent years the Russian Government redoubled its
of Russia to procure right efforts to modify the existing rule of the Straits, so as to of passage. secure the right of passage for its public vessels. To achieve this object various diplomatic combinations were established in $\operatorname{turn}(a)$. First, Russia arranged to cooperate with Germany and Austria as against Turkeya co-operation that was brought about, on the one hand, by the sinister engagement entered into at Reichstadt,

Various combinations sffeeted. and, on the other, by the Russo-Japanese War. For it was at Reichstadt, July 8, 1876, that the Emperor Francis Joseph in his interview with the Tsar agreed to preserve neutrality during the Russo-Turkish War, on condition that Bosnia and the Herzegovina should be occupied by Austria. Conformably to this agreement the Treaty of Berlin assigned the occupation and administration of these countries to Austria-Hungary, which thus became a Balkan State; and the formal annexation in 1908 (in contravention of the treaty) reinforced her position as such. As this combination with the Central Powers proved unsuccessful, Russia next endeavoured to arrive at an understanding with

(a) In this chapter the writer is much indebted to Hoschiller, op. cit., especially for his references to and citations from Russian papers. 
the Ottoman Porte as well as with the Balkan States, irrespectively of Germany and Austria. This step, too, failed. Thirdly, she went to the side of the Balkan States as against Turkey as well as the Central Powers. Finally, she took up arms against the Central Powers in the present war and was determined to settle once for all, among other questions, the problem of the Straits.

Let us consider very briefly the later stages of the The Austrian struggle-at first diplomatic and now become a conflict 1908 . to the death-to untie this most difficult knot of European politics. The annexation of Bosnia and the Herzegovina (October 7, 1908) and the proclamation of Bulgarian independence (October 5, 1908) could not but raise the question of the Straits. The unilateral denunciation by Russia in 1870 of certain Articles of the Treaty of Paris appeared to have become a fateful precedent. European public opinion asked, in alarm, what was to become of solemn international treaties. As Prince Gortchakoff had in 1870 suggested that a conference of the Powers should apply itself to the task of considering the grievances of Russia and revising the obnoxious stipulations of the Treaty of Paris relative to the Black Sea and the Straits, so now the Russian Foreign minister, M. Isvolski, proposed that a conference should be arranged for the purpose of examining the proceedings of Austria and effecting a definitive solution of the Straits question. Russia declared that in return for the benefits accruing to Austria and Bulgaria, as a result of the violation of the Treaty of Berlin, she would herself be satisfied with a minor concession, viz. the opening of the Bosphorus and the Dardanelles to her warships. Thus, Count Aehrenthal having undertaken not to oppose the revision of the rule of the Straits in accordance with the Russian demand, M. Isvolski promised to acquiesce in the annexation of the Turkish 
provinces. England, however, in view of the existing political circumstances in Turkey, thought the summoning of a European Conference inopportune, especially if its object was to be the revision of the Straits régime.

Plan for

forming a

Balkan

League.

Rassia's step in the TurcoItalian War, 1911.

After the annexation of Bosnia and the Herzegovina, the Balkan States, desiring to oppose the increasing Austro-German influence, turned to Russia for support. A plan was then designed for establishing a Balkan League, of which Turkey should be a member. It was intended to serve, on the one hand, as a barrier against Germanic expansion, and, on the other, as a means for facilitating the consummation of Russia's long-cherished desire to secure free navigation for her vessels of war in the Straits. At the end of November, 1911, in the Turco-Italian War, soon after Italy had announced her intention to blockade the Dardanelles, the Russian ambassador at Constantinople, M. Tcharikoff, had a conversation with the Grand Vizier and the Turkish Foreign Minister on the question of modifying the Straits régime. $\mathrm{He}$ endeavoured to show them that the opening of the Straits to the Russian military flag would not at all be disadvantageous to Turkey. But the Ottoman ministers pointed out that they could not enter into negotiations on the subject without the concurrence of all the other Powers signatory to the Treaty of Berlin, and declared that, even if the assent of the latter were given, they were not prepared to modify the existing status quo in the sense suggested. On December 4 the Russian Government raised the question once more, this time in a more direct and explicit manner: a Note was delivered to the Porte claiming liberty of passage for the Tsar's vessels of war, whilst maintaining the old principle of exclusion for the warships of other foreign States. The following day the Russian ambassador called for a reply. The Sublime Porte replied that 
such a serious departure from the stipulations of the treaties concerned could not be made without the cooperation of the other signatory Powers. On December 6 the Jeni Gazetta, apparently inspired by the Turkish Foreign minister, made the following statement $(b)$ : ' The step taken by Russia is the most important event that has occurred in Turkish history for forty years. It would be superfluous to insist on the import of the Russian action, which was as unexpected as formidable. The attitude of the Porte in this affair is clear; we remain resolutely attached to our most vital interests. No Government, no Turk, can for a single moment entertain the idea that the great Ottoman Empire can fall to the level of a Russian vassal. Although we do not officially possess any communiqué, we can declare to the Ottoman people that the Porte will refuse to comply with the Russian suggestions.'

The position taken up on this occasion by Great Attitude of Britain and France showed a remarkable change of view and France. on the part of these Powers. They intimated, in reply to inquiries from the Porte, that if the Turkish Government offered no opposition to the opening of the Straits to the military flag, they themselves would consent to the departure from the existing rule; and that if Turkey did oppose the demand they would refrain from exercising pressure on her. On the other hand, Germany and Austria stated that they were against the proposed modification, and urged Turkey to adhere to the existing régime, in the absence of an arrangement ensuring her interests as well as those of the other Powers concerned. Immediately afterwards the German ambassador at Constantinople, Baron Marschall von Bieberstein, made a declaration to the same effect and emphasised the AustroGerman consensus on the subject.

(b) Quoted by Hoschiller, op. cit. p. 65. 
Turkish reply to Russia.

AustroGerman opposition to Russia.

Balkan League.

Thereupon the Ottoman Cabinet issued, December 8, the following reply to the demand presented by the Russian ambassador $(c)$ : 'The Imperial Government, conforming to the treaties existing till 1871 and ratified by the Congress of Berlin, cannot authorise the exclusive passage of the Russian fleet through the Straits in time of peace as in time of war, and declares that all rights over the Straits belong exclusively to the Ottoman people and its sovereign for the protection of the territorial integrity.'

On the same day an interview with M. Sazonoff, the Russian Foreign Minister, appeared in the French newspaper, Le Temps (December 8, 1911). He was obviously anxious to remove the impression that the Russian Government had met with a rebuff: for he observed that the overtures made to the Sublime Porte were not of an official character, but were due merely to conversations of an 'academic' nature between the Turkish minister and the Russian ambassador, who had indeed acted without special instructions.

The affair showed Russia clearly and definitively that her Straits policy, though not now opposed by Great Britain and France, was to be combated by the AustroGerman combination, and that her interests in the Near East were imperilled through the predominating influence which Germany now exercised at Constantinople. ' La Turquie, dorénavant, était inféodée à la politique germanique' $(d)$.

Seeing that she could not attain her object by a separate understanding with the Porte, Russia thought the establishment of the Balkan League (in 1912), which excluded Turkey and Austria, might prove a more successful means for achieving her end. She declined a

(c) Quoted by Hoschiller, op. cit. p. 66.

(d) Ibid. p. 67. 
proposal made by Austria for the conclusion of a new treaty, whose basis was to be similar to that of the agreement made at Reichstadt in 1876 in regard to the Austrian occupation of Bosnia and the Herzegovina, and of the arrangement entered into at Buchlau more than thirty years later relative to the Austrian annexation of these provinces (1908).

However this may be, the expectations of Russia were Firat Balkan once more frustrated; for instead of securing the keys War. of the Straits from Turkey as a result of the latter's reverses in the Balkan wars, she found herself at loggerheads with victorious Bulgaria, thanks to the astute diplomacy of Germany and Austria. The German and the Austrian official press sang the praises of 'Great Bulgaria,' declared, in view of the Turkish retreat, that the Ottoman capital was the only fitting place for Ferdinand to make peace in, and that the Bulgarian occupation of Constantinople would be advantageous to Russia. Moreover, Germany intimated to Ferdinand that she had no objection to the opening of the Straits. But Russia was opposed to the march of the Bulgarians towards Constantinople (e), much to the resentment of the King of Bulgaria. By the Treaty of London, May 30, 1913, between Turkey on the one side, and Bulgaria, Greece, Serbia and Montenegro on the other, the Bulgarians had to withdraw from the points they had reached on the coast of the Sea of Marmara; the Sultan ceded (Art. II.) to the allied Sovereigns all his European territories to the west of a line drawn from Enos on the Egean Sea to Midia on the Black Sea, with the exception of Albania. Thus the Straits question was left as it was, without any solution having been attempted.

The next Balkan War again showed the great incon- Second $\underset{\text { Balkan War. }}{\text {. }}$

(e) Cf. G. Hanotaux, Etudes diplomatiques. La guerre des Balkans et l'Europe (Paris, 1914), pp. 166 seq. 
veniences resulting from the existing régime of the Straits; international interests and commercial navigation had suffered considerably. The Treaty of Constantinople, September 29, 1913, between Turkey and Bulgaria, and the Treaty of Athens, November 14, 1913, between Turkey and Greece both contained a great variety of provisions and carried out numerous territorial changes, but left the status of the Straits entirely unaffected.

Russia's effort in June, 1914.

Another effort was made by Russia the following year. After the meeting at Constanza between Tsar Nicholas II. and King Carol of Roumania (June 14), the Russian and Roumanian ambassadors at Constantinople presented similar Notes to the Ottoman Porte (June 21), couched in amicable terms, pointing out that the recent experiences in the Greco-Turkish war showed the great disadvantages of closing the Dardanelles to commercial navigation, especially so to the littoral States of the Black Sea. A few weeks later the Straits were closed again on the outbreak of the Great War. Russia took up arms in the hope that on this occasion the problem of the Straits would be definitively solved. As to what solution was most desirable, Russian opinion was by no means unanimous, and the divergence, as we shall presently see, became more accentuated as a result of the Revolution.

We have already referred to the recent development of slavophilism and indicated its fundamental tenets. We have also pointed out that the panslavists were opposed by those who belonged to what may be called the western school of political and social philosophy. The former have looked on Constantinople as the future capital of a panslav federation, and on the Bosphorus and the Dardanelles as future possessions of Russia. The 
latter, on the contrary, generally held the view, which they frequently expressed during the Balkan Wars, that Constantinople should be constituted the metropolis of a Balkan Confederation, that its port should be open to all nations, and the fortifications of the Straits should be destroyed, and the Straits themselves internationalised.

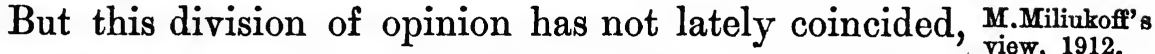
and does not now coincide, with the division of parties. We find, for example, constitutional democrats (the 'Cadets'), such as M. Miliukoff (temporarily Foreign Minister of Russia in the Provisional Government), advocating before the Great War a policy that contains certain slavophil elements. Thus the latter writing in 1912, in the organ of his party, concerning the efforts of the Russian Government in 1910 to secure by amicable means the freedom of the Straits, observed: 'From the point of view of international law the opening of the Straits is possible only if they are neutralised, like the Suez Canal $(f)$. But this solution would not be advantageous to us. The solution truly advantageous to us, and already indicated in 1877 by Nelidoff-that is to say, the opening of the Straits only for our vessels-would meet with obstacles from foreign Powers. . . . The right alone, if not protected by territorial "enclaves" and fortresses, which the Emperor Nicholas I. imagined, is not of great importance even if we obtain it later at a more favourable moment' $(g)$. This view, viz. the possession of the Straits by Russia, soon became the predominating one.

As a counterpart to M. Miliukoff's policy as set forth Viewo baron in 1912 , there is the Asiatic policy, as expounded in 1913 . ${ }^{\text {Rosen }}$, 1913 in a remarkable memorandum from the pen, ap-

(f) The Suez Canal is not 'neutralised'; it is internationalised, as we shall see in a later chapter.

(g) Quoted by Hoschiller, op. cit. pp. 77, 78. 
parently, of Baron Rosen, who has had great experience as a diplomatist in the capacity of Russian ambassador at Belgrade, Tokio, and Washington, and plenipotentiary, along with M. Witte, at the Portsmouth Conference of 1905. It was a confidential, if not a secret, memorandum, entitled the 'European Policy of Russia,' which was written in September, 1912, and was issued anonymously; but it was soon afterwards withdrawn from circulation, probably by order of the Government $(h)$. The authorship is deducible from, among other reasons, the fact that the writer refers to the positions he has occupied. A summary of this production, accompanied by numerous quotations, was published in the French review, Le Correspondant, September, 1913. It will be of particular interest here to present the main points that are advanced by the distinguished author.

There is no real basis, he declares, for the slavophil imaginings. Russia has no historic mission in the Near East. She does not need the Slav world, and the Slav world does not need her. It is the Slav ideal that impelled Russia to go to war against Turkey in 1877, and afterwards brought about the estrangement with Germany, and the dissolution of the alliance between the three Emperors, which guaranteed the western frontier of Russia (i). The Slavs of the South will find it more advantageous to establish commercial relations with Austria-Hungary, their neighbour, than with distant Russia; and they have more sympathy with Germanic culture $(k)$. Austria, excluded from the Germanic Confederation, has turned her eyes towards the Slav south as the only outlet her geographical position allows. Her movement in this direction does not conflict with Russian

(h) Cf. G. Alexinsky, Russia and the Great War. English translation (London, 1915), p. 25.

(i) Le Correspondant (Paris), September, 1913, p. 1020.

(k) Ibid. p. 1021. 
interests; on the contrary, she will find the condition of things there sufficiently complicated to make her desire friendly relations with Russia(l). The partition of Poland has already established a bond between them. As to the Straits question, the antagonism between England and Russia produced the coalition of 1854 and the mortification at the Berlin Congress. To realise the dream respecting Constantinople will be the beginning of Russian disaggregation. The Straits are not 'the keys of our house.' In the Black Sea Russia is mistress. In time of war, however, egress may be prevented if a superior enemy fleet blockades the Dardanelles; whilst the entrance will be at the mercy of the Power that possesses both sides of the Straits. Will this Power be an ally of Russia or of the enemy? The permanent possession of the Straits by Russia will provoke the resistance of Great Britain and other Powers, especially Bulgaria. The true interests of Russia, like those of the rest of Europe, demand merely the liberty of the Straits, which could be established by a scheme of neutralisation, as in the case of the Suez Canal $(m)$.

This obsession of Constantinople and the Straits, the writer emphasises, is particularly dangerous ; it displaces the axis of the true policy of Russia by turning her away from her Asiatic Empire, and threatens to involve her in a European war.

Europe is divided into two hostile camps. Both the Franco-German antagonism, due to the disasters of 1870 - 1871, and the Anglo-German rivalry in matters commercial, industrial, colonial, and in naval armament, are foreign to the vital interests of Russia. The AustroRussian antagonism is the outcome of Slav ideals, which do not involve the real interests of Russia. It is essential, 
therefore, to get rid of this opposition; otherwise such complications will arise as will bring about a European conflagration in which Russia will be compelled to participate despite her sincere love of peace $(n)$. The tendency of Germany to acquire hegemony on the continent is not prejudicial to Russian interests $(o)$; it affects only the Western Powers. For Russia is not merely a European Power, but also an Asiatic Power, and her main mission lies in Asia. The object of the Triple Entente is to preserve the mastery of the sea; but this is of small interest to Russia $(p)$. The confidence of Russia in England and France rests on a fragile basis, whereas confidence placed in Germany is ' incommensurably more precious to us.' Therefore the Franco-Russian alliance should be converted into a Franco-Russian-German alliance.

A Russo-German alliance would manifestly be disastrous to European interests in general, if Prussian militarism exercised its baneful influence therein; and a former member of the Duma holds that few Russians will regard these germanophil counsels as being compatible with the true interests of their country $(q)$.

Juristic riew. We may here point out that there is in Russia another school of political thought, differing from the advocates of annexation as well as from those of the Asiatic policy, and basing their views on the general principles of international jurisprudence. Thus Count L. Kamarowski, professor of international law at the University of Moscow, and associate of the Institute of International Law, writing in 1888 on the political causes of war in modern Europe $(r)$, mentions as one of the main causes

(n) Le Correspondant (Paris), September, 1913, p. 1025.

(o) Ibid. p. 1027.

(p) Ibid.p. 1028.

(q) Cf. Alexinsky, op. cit. p. 30.

(r) Des causes politiques de guerre dans l'Europe moderne, in Revue de droit international (Bruxelles), vol. xx. (1888), pp. 140, 141. 
the Near Eastern problem. There are three States, he says, that may claim the possession of Constantinople, viz. Greece, Russia, and Bulgaria. It is improbable that Greece will be ever established on the Bosphorus. 'There is no reason for desiring the restoration of the Byzantine Empire.' The Greeks proved formerly to be incapable of protecting it against the Turks, and allowed them to subjugate the whole Balkan peninsula. Moreover, it would be unjust to place the Southern Slavs at the mercy of a Greek Empire. As to the Black Sea, it is not now a territorial sea of any State, therefore closing it to warships cannot be justified. Russia, Austria, and the neighbouring Slav countries are fully entitled to the right of ingress and egress. From the point of view of international law, Russia cannot be allowed to have exclusive control over the Straits, since they are for the countries bordering the Black Sea the natural and shortest route for their intercourse with the rest of Europe, and, by the Suez Canal, with the Far East. Hence, Constantinople should become the capital of Bulgaria or of the Slav Federation, or a free town with a small surrounding territory; and, in any case, the fortifications on the Straits should be demolished, and the whole placed under the guarantee of Europe. Whatever be the destiny of Constantinople, the flags of all nations should obtain the right of passage between the Mediterranean and the Black Sea. As for the Ottoman Empire in Europe, 'Turkey, after disappearing from the list of European States, might peacefully continue her existence in Asia.'

Next we have to consider Russian opinion as affected Influence of by the present war. As soon as Turkey took up arms, the pros the press in Russia began to discuss the fate of Con- opinion. stantinople and the Straits. The views expressed by leaders of thought were not at all unanimous. In 
October, 1914, the Exchange Gazette of Petrograd held an inquiry into the question: 'The sick man is dyingwhat is to be done with the inheritance?'

Straits neutralised, and Constantinople a free town.

Professor Alexeieff, of Moscow, was inclined to believe that the Straits question will perhaps be solved by neutralising the Bosphorus and the Dardanelles, and placing them under the control of the Triple Entente. Such a solution, however, would not sufficiently safeguard the interests of Russia, and it would be more advantageous for her to possess the Bosphorus. 'But it is doubtful,' he adds, 'whether the possession of Constantinople would be of any use to her. The administration of its population so refractory to order would be a source of perpetual troubles. We must also reckon with the Greek millennial dream of possessing Byzantium. . . . The best solution would be to make of Constantinople a neutral and free town, as Hamburg was formerly. The protectorate of the European Powers will guarantee to the ancient city its free development and economic prosperity. The mode of administering such a town is a question of detail. A different combination may, of course, be imagined: for example, the possession of the Bosphorus by the Russians, and of the Dardanelles by the English. In any event, Constantinople ought to become a free and neutral town' $(s)$.

The veteran slavophil, M. N. Dournovo, was of the opinion that the Turks should be driven out of Europe into Asia Minor, and Constantinople placed under the control of the Powers of the Triple Entente; that the Greeks were entitled to administer their ancient capital, subject to the protection of Russian interests in the Straits. If Constantinople were made a free town,

(s) Quoted by Hoschiller, op. cit. pp. 78, 79. The subsequent quotations from Russian sources are taken, unless indicated otherwise, from the French translations given ibid. pp. 79-95. 
administered by the Greeks under the control of the Triple Entente, Russia would secure a free passage from the Black Sea to the Mediterranean.

Many leading Russians shared the view expressed by The Black a 'high diplomatic personage,' whose name was not re- Russian lake. vealed by the Petrograd journal: 'The Black Sea,' he thought, 'ought to become a Russian lake so that no one may enter it without the permission of Russia, but that the latter may be empowered to go out at her pleasure. It would be necessary to raze the fortresses of the Dardanelles and to make of the Bosphorus a Russian Gibraltar, by occupying a strip of territory on the Asiatic and European sides of the Strait. The fate of Constantinople would be then decided by itself. But Position of the transformation of Constantinople into a Russian town nople. would take us too far away from our base, for the possession of towns that are not connected by land with our territory would be contrary to the fundamental basis of our policy.'

A similar point of view with regard to the Ottoman capital is adopted by Professor Kotliariersky of Moscow, who says: "The Straits must belong to us and they will belong to us. The question of Constantinople is a secondary one as compared to that of the Straits. Whether Constantinople be a free town or be placed in the hands of the Greeks or the Russians is of no importance.'

Professor Baikoff, however, believes that the internationalisation of Constantinople might produce results prejudicial to Russian interests: 'In general, it is diffcult to conceive precisely how Constantinople may become a free town. History does not offer any examples of the kind. The internationalisation of such an important town will be taken advantage of by any Power, and fresh misunderstandings will certainly arise, especially in case of war.' 
Free passage necessary.

The editor of the Exchange Gazette concluded the inquiry by emphasising that it is essential for Russia to obtain free passage through the Straits, to become a Balkan Power, and establish a customs union with the other Powers of the peninsula: 'Our policy, which is manifested by the secular conflicts with Turkey, has brought into being a number of independent nations in the Balkans. ... The hour has come for thinking a little of our own interests, of the realisation of the dream cherished by so many Russian generations who sought access to the open seas. From the moment that the main burden of the war with Germany and Turkey was placed on our shoulders, we acquired the right to demand from our allies that they should take our interests into consideration. . . . Wallachia, Moldavia, Serbia, Greece, Montenegro, Bulgaria, all these States were created as a result of the efforts of our troops. In establishing them we have set up, with our own hands, a barrier excluding us from the Agean Sea. Are we to continue to follow this traditional policy of timidity which has led us to yield always before Europe, and this at the very moment when the Turks are losing their last possessions in Europe? We are the natural heirs of Turkey in Europe, we must now become a Balkan Power. After becoming a Balkan Power, Russia must conclude with the other States of the peninsula a customs union, and at the same time a military convention, after the fashion of Prussia who established in 1866, after her victorious war against Austria, the Germanic Confederation, which was later transformed into the German Empire. The prospect of a customs union between the Balkans and Russia promises to both sides incalculable economic advantages; and as for the military convention, it will be the only means of putting an end to the incessant disputes of these small States which envy and fear each other. But 
all this is possible only on condition that Russia will acquire rights over the Bosphorus and the Dardanelles as well as over the European and Asiatic adjacent territories of Turkey. Such a task is alone worthy of Russia and of the sacrifices demanded by the present war.'

The committee of the Industrial and Commercial Possession of Association-the leading economic organisation of Russia the Straits. - published in its organ an article which, after considering the commercial side of the question, deals with the political aspect. Since the commencement of the war, it says, various solutions have been brought forward. It is recognised, on the one hand, that Turkey is too weak to maintain her power over the Straits without being dominated by a State hostile to Russia, and, on the other hand, that the acquisition of the Straits by a third State would complicate matters still more. The suggestion that the Bosphorus should go to Russia and the Dardanelles to another Power must be rejected, inasmuch as the combination thereby produced would prove to be at once an artificial and a dangerous one: whoever commanded the access to the Egean Sea could deal a blow at Russian commerce, just as the Turks did when they closed the Bosphorus in 1911 and 1914. As to the proposal for neutralising Constantinople, i.e. making it a free city, and placing it under the joint control of several States, we cannot be certain that the controlling States would always agree; rivalries would certainly arise and endanger the situation. Moreover, Russia would not necessarily obtain thereby unimpeded access to the open seas, any more than Serbia had obtained ' commercial access' by the artificial creation of Albania. The only solution, then, in the interests of Russia is, that she should exclusively possess the Straits. ' No territorial extension in the West or in the Caucasus 
can assure us the external security that is absolutely necessary to the economic development of Russia-a security that can be obtained only by the acquisition of the Straits. Every compromise, every postponement of the solution to a further date will simply bring new candidates into the field who will insist on participating in a problem that concerns principally and above all Russia. Under Nicholas I. only four Powers-England, France, Prussia, and Austria - had to be reckoned with; to-day, Italy, Greece, Bulgaria, Roumania must also be taken into consideration. Are we to wait for the time when the United States of America and Japan will be interested in this question of the Straits? The former Power already has commercial interests in Turkey. In any case, compromises, without safeguarding us from the difficulties experienced by the closing of the Straits in $1911-1914$, threaten to create new complications. If, after consenting to make innumerable sacrifices in men and wealth and after enormous efforts, Russia does not this time manage to solve definitely this fundamental question of her existence, we shall have to confess that all these sacrifices were in vain, and that once more she has worked for others without having been able to defend her own vital interests.'

Russian official views, January, 1915.
As soon as the Anglo-French fleets had commenced operations against the Dardanelles, various pronouncements, official and other, were made in the Duma.

At the sitting of January 27, 1915, M. Goremykin, president of the council, used the following veiled expressions to convey what was apparently the intention of the Government: 'Turkey has joined our enemies, but her military forces have already been shaken by our glorious troops of the Caucasus; and more and more clearly is delineated before us the radiant future of Russia, yonder, on the shores of the sea, at the walls of Constantinople. 
The foreign minister, M. Sazonoff, did not on that occasion mention Constantinple, and confined himself to emphasising the access of Russia to the open sea. 'The moment is approaching,' he observed, 'when the economic and political problem will be solved as a result of obtaining access to the high seas.'

But private members of the Duma proclaimed their views more explicitly. Thus M. E. Kovalevsky said in a speech that called forth the applause of the House: 'Amongst the principal questions which this war must solve for Russia, we must place in the foreground the consummation of our secular struggle with Turkey round the Bosphorus and the Dardanelles. . . . . The Straits are the lock and key of our house; they must therefore be placed in Russian hands, along with the necessary territories on both shores.'

The observations made by M. Miliukoff, the leader of the constitutional democrats, were also loudly applauded: 'We have heard with satisfaction the declarations made by the head of our foreign policy, and have learnt that the realisation of our national task is on the right road. We are convinced that the realisation of the chief of these tasks-the acquisition of the Straits and of Constantinople-will be assured at the proper time by both diplomatic and military measures.' In a public speech made a few days later at Moscow (January 31), M. Miliukoff urged the same view, and declared that Russia 'must make haste to take the Dardanelles as soon as possible, so as not to be behindhand' $(t)$. Similarly, in his publication entitled, What Russia expects from the War, he demands the Bosphorus and the Dardanelles, together with Constantinople and adjacent territory sufficient to ensure the protection of both shores.

In connection with the concerted measures of the Sir Edward ( $t$ ) Alexinsky, op. cit. p. 304.

Grey's answer, Feb. 1915. 
Allies against the Straits, an understanding was reached that if Constantinople was thereby taken it should eventually go to Russia. In reply to a question in the House of Commons, however (February 25, 1915), Sir Edward Grey said that the British Government sympathised with the aspiration of Russia to gain access to the open sea, but that ' the precise form in which it would be realised would no doubt be settled in the terms of peace' $(u)$.

Russian press on Sir Edward Grey's statement.

Commenting on this statement the Exchange Gazette maintained that the 'form' which the access to the open sea would assume was already settled. The Rietch and the Petrograd Courier asserted that the Russian official declarations on the subject of the Straits and Constantinople were perfectly explicit, that they were regarded both by the Duma and the nation as an irrevocable decision of the Government, and that the Russian people would suffer no obstacle, from any source whatever, to come in the way of its aspiration. This point of view was adopted by other Russian newspapers, which condemned the suggestions made in the French press as to neutralising the Straits and making Constantinople a free city. Russian views
as to position In order to reassure the Russian people as to the goal in view and the attitude of the Allies, the following communiqué was published by the Official Telegraphic Agency of Petrograd: 'In the Russian community the conviction prevails that the Allies will not oppose the accomplishment of the national task of the Empire. It is true that in recent years objections have been advanced by Roumania and Bulgaria, who have considered the neutralisation of the Straits for the commercial flag as well as for the warships of all nations as an equitable

(u) Parliamentary Debates, House of Commons, 5th series, vol. lxx. col. 364 . 
solution. But little importance is attached to these objections in Russian political circles, which are convinced that the diplomatists of Russia acting in harmony with those of the other members of the Triple Entente will be able to surmount the difficulties existing in Roumania and Bulgaria. It has, however, been lately suggested in certain political spheres that the Allies, especially Great Britain, would not consent to the annexation of the Straits by Russia, and it has been asserted that France, too, was in favour of the complete neutralisation of the Straits, after the manner of the Suez Canal ; the administration of Constantinople by a small State, for example, Belgium, was even proposed. It has also been said that England would endeavour to force the Dardanelles as soon as possible and occupy Constantinople without Russian co-operation, in order to acquire the exclusive right to dispose of them at her pleasure. The evasive declaration of Sir Edward Grey in the House of Commons appears to confirm these rumours; but in well-informed political circles all these rumours are regarded as baseless, and the assurance prevails that England, and with her France, will not, after the war, oppose the Russian annexation of Constantinople and the Straits. The evasive reply of Sir Edward Grey is explained mainly by the inexactness of the question addressed to him. Indeed, Sir Edward Grey was asked in the House of Commons if it was with the consent of Great Britain that M. Sazonoff had informed the Duma of Russia's intention to occupy Constantinople permanently-which the Russian minister did not say. Therefore Sir Edward Grey replied that he did not find any such intention expressed in the speech of the Russian minister. Moreover, according to well-informed political circles he replied evasively because in England public opinion, as well as the House 
of Commons, is not yet sufficiently prepared for the head of the British foreign policy to make concrete declarations on the subject, inasmuch as the moment for announcing a definitive solution is not yet near. Just as the evasive reply of the King of England to the President of the French Republic, when the latter asked whether England would support France in case Germany declared war on her, did not prevent the English people from going to the aid of the friendly nation, so-it is asserted in well-informed political circles-the present evasive reply of Sir Edward Grey on the subject of the future of Constantinople will not prevent English diplomacy from supporting Russia in the solution of the Straits question, when the time arrives.'

Views of Prince Troubetzkoi, March, 1915.

In March, 1915, Russian expectations ran high when the Black Sea fleet proceeded against the Bosphorus, in co-operation with the Anglo-French forces who were endeavouring to cut a way through the Dardanelles. At the same time, Prince Eugene Troubetzkoi, a leader of Russian liberal politics, published an article in the Moscow democratic journal, the Rousskia Viedomosti (March, 1915), in which he defined the aims of Russia in the present war and pointed out to allies and enemies alike what seemed to him and to the Russian people to be the only satisfactory solution of the Straits question. 'There is only one solution,' he declared, 'that corresponds to our national interests: Constantinople and the Straits must become Russian. Every other solution is for us unacceptable, because far from bringing about an amelioration it will entail a distinct aggravation of our position in comparison with that which existed before the war. When the operations against the Dardanelles were begun a part of the French press spoke of the neutralisation of the Straits. I am certain that our allied press will change its opinions when it learns in 
what dangers neutralisation will involve us. Taken in the strict sense of the word, it signifies the right of passage not only for merchantmen but also for warships in the Black Sea. We know what a worry the Goeben alone was to us; can we agree, after a definitive victory, to remain always exposed to the possible appearance in the Black Sea of two dozen dreadnoughts? Can anyone Possession of suggest a solution, other than the possession of the Straits $\begin{gathered}\text { the Straits by } \\ \text { Russia. }\end{gathered}$ by Russia, which will guarantee us against such an eventuality? Perhaps we shall be asked to interpret "neutralisation" in the sense of the right of passage only for the commercial fleet. But where is the guarantee that neutrality, as thus understood, will be respected? We know how Germany treated the neutrality of Belgium, what respect she professes . . . for "scraps of paper." It is manifest that the dismantling of the fortifications and the neutralisation of the Straits will for her amount to an invitation to use them for her own ends. In that case Russia will be compelled to spend enormous sums for the defence of her southern shores and for her Black Sea fleet, and will remain liable just the same to be blockaded and cut off from the open sea by any enemy Power. It would be better, then, to leave the Straits in the hands of feeble Turkey ... if feebleness could be compatible with independence. But the present war has proved conclusively that such compatibility is impossible. If we neutralise the Straits, or leave them to the Turks, or surrender them to a small State, for example, Belgium, they will in course of time fall under the sovereignty of an enemy Power, viz. Germany.' The writer emphasises that the Straits question is now equivalent to the question of Russian independence, and that neutralisation would make his country politically and economically dependent on Germany. "Russia can and ought to engage herself to grant free access to the Sea of Marmara and the Black 
Sea to the merchantmen of all nations. But she must be in a position to prevent by force of arms the navigation in these seas of the warships of any State whatever. There is only one way to ensure us this power, as well as access to the open sea. The Straits must belong to Russia. There can be no other solution.'

Russians in favour of neutralisation.
Notwithstanding this emphatic pronouncement, large sections of the Russian people were prepared to accept the principle of neutralisation if the execution of the treaty establishing this were to be entrusted to the Russian Government; they assured the world that commercial liberty might well accord with Russian sovereignty. A régime, it was thought, that was possible for the Panama Canal, could equally well be applied to the Bosphorus and the Dardanelles $(x)$.

Again, other Russian writers and politicians accept the principle of neutralisation without making any condition as to Russian supremacy, and reject the panslavist idea in regard to Byzantium. Thus, M. Alexinsky, a former member of the Duma, whose view undoubtedly represents the views prevailing amongst considerable sections of the Russian population, says that the arguments of a religious and historic character are untenable; they are merely 'the verbal and metaphysical embroidery of the economic and political aspirations of the Russian nationalists ' $(y)$. The talk of Russia's sacred duty to plant the Orthodox Cross on the dome of St. Sophia at Constantinople, and to take away from the Turks the heritage of the Byzantine Emperors, and so forth, is nothing more than a stringing together of words devoid of concrete meaning. 'If the Orthodox Russian Church has been able to do without St. Sophia for so many

(x) The Russian newspaper, Rietch, quoted by the Italian paper Corriere della Sera, April 1, 1915.

(y) Alexinsky, op. cit. p. 302. 
centuries, it can do without it in the future; and the 'Russian monarchy can very well do without Byzantium'( $z)$. Referring to M. Miliukoff's pronouncements The mass of in favour of territorial acquisitions in the Straits, peopleagianst M. Alexinsky observes: 'In this case, as in so many acquisition. others, the leader of the Russian liberals does not express the true feelings and aspirations of our democracy during the present war, for whom the present war is not a war of conquest and usurpation, but simply a war to defend Russia and Europe against the brutal aggression and domination of Germany' $(a)$. On the contrary, he maintains that the possession of Constantinople and the Dardanelles is not necessary for the realisation of Russia's true interests. Undoubtedly Russia must have an outlet for her cereals and other southern products; but the economic interests of other countries are also concerned in the Straits question. He points out that in 1909-1910 of the total tonnage of vessels entering the port of Constantinople 41.7 per cent. flew the British flag, 17.7 the Greek, 9.2 the Austrian, and only 7 per cent. the Russian flag. He concludes, therefore, that, taking everything into consideration, the best solution is the neutralisation of the Straits and Constantinople; and that in the new administration to be set up conformably thereto the Balkan States-Roumania, Bulgaria, Greece, and Serbia-should be allowed to participate along with the Great Powers. There is another and very important advantage to be derived from such a solution, viz. the elimination of the main cause of disagreement between Russia and Great Britain, who cannot allow Russia to be in a position to threaten the Mediterranean, the Balkan States, and Asia (b).

Finally, with the coming of the Revolution Russian Effect of the

(z) Ibid.

(a) Ibid. p. 305.

(b) Ibid. p. 303.

$14(2)$ 
authoritative opinion has in many quarters undergone a remarkable change. Whilst there remains here and there a lingering desire for territorial acquisitions, whilst the eyes of some Russians are still turned in the direction of Constantinople and the Straits, the preponderating opinion of the people and the expressly declared view of the existing Provisional Government is against annexation. It is true that early in April, 1917, M. Miliukoff, the then foreign minister, issued a statement to the press on the aims and purposes of the war, in connection with the intervention of the United States, wherein he demanded not only a free Poland, but also the Russian mastery of the Straits, as an essential condition of future peace $(c)$. A few days later, however, the following proclamation of Prince Lvoff, the Russian Prime Minister, was issued by the Provisional Government: '. . The Government deems it to be its right and duty to declare now that Free Russia does not aim at dominating other nations, at depriving them of their national patrimony, or at occupying by force foreign territories; but that its object is to establish a durable peace on the basis of the rights of nations to decide their own destiny. The Russian nation does not lust after the strengthening of its power abroad at the expense of other nations. Its aim is not to subjugate or humiliate anyone' $(d)$. Nothing is here said of Constantinople and the Straits; but by the tenour of this official announcement the old claims thereto are now definitively abandoned. We may conclude this chapter by mentioning that according to reports from Petrograd, published in the English press on May 15, 1917, M. Miliukoff has himself renounced all claims to Constantinople $(e)$.

(c) Petrograd, April 5, 1917 ; seo The Times, April 9, p. 5.

(d) Petrograd, April 10, 1917 ; seo The Times, April 11, p. 6.

(e) See Daily News, May 15, 1917. Shortly afterwards he resigned his office in the Provisional Government. 


\section{CHAPTER III.}

OPINION OU'TSIDE RUSSIA-VARIOUS SCHEMES SUGGESTED.

$\mathrm{WE}_{\mathrm{E}}$ have seen that opinion in Russia as to the disposal of Constantinople and the Straits has not been and is not now unanimous; it is clear, however, that before the revolution Russian opinion was for the most part in favour of the annexation of Constantinople and supremacy in the Straits, but that after the revolution the current of opinion veered round, and territorial aggrandisement was openly renounced by the responsible and generally accepted Provisional Government.

Even before this momentous event there were very Views outside few publicists and writers outside Russia who advocated the cession of Constantinople to her and her mastery of the Straits. A French writer, writing in $1915(a)$, sug- In favour of gests that, when the settlement of the war comes to be acquisition. made, Constantinople should be assigned to the greatest Power of the Black Sea, that is, Russia; and that, having regard to geographical considerations, a maritime passage should belong to the most important of the countries that depend upon it: 'Selon la logique géographique, ce qui constitue un passage doit appartenir au plus important des pays qui en dépendent.' Such a conclusion does not merit serious examination, for it is based neither on the logic of geography nor on the logic of jurisprudence and morality, nor, indeed, on any other kind of logic, unless it be the logic of an unconscionable military supremacy - which most of the present bellige-

(a) A. Sardou, L'indépendance européenne (Paris, 1915), pp. 63, 64. 
rents have determined to crush. The same writer suggests further that the Bosphorus, the Dardanelles, Gallipoli, the eastern and western coasts of the Sea of Marmara and its islands should constitute a new State of Constantinople; and he says there are two solutions for its régime : either to make it a Russian possession subject to guarantees of commercial liberty to all Powers, or to make it an internationalised neutral State, in whose administration the various Allies would be able to participate in a determined manner. Of these two solutions he is inclined to accept the first : the ancient capital of the Eastern Empire should go to Russia.

A recent English writer $(b)$ suggests, among the peace terms, that 'Russia's right of entry into the Mediterranean be established; Constantinople be put under Russian protection, and the Cathedral of St. Sophia given to the Russian Orthodox Church; St. Sophia so becoming the St. Peter's of the Eastern Orthodox Church-one arm being the Patriarchates of Jerusalem and Constantinople, the other the Patriarchate of Moscow.'

Some writers (c), thinking of the difficulties inherent in the establishment of Constantinople as a free port and city under international control, are therefore driven to the opinion that if Russia, 'whose desire for an ice-free port has been the keynote to her policy of expansion in Europe, desires the city, it is at least doubtful whether we should be wise to oppose her wish.' In support of this view it is urged that the annexation by Russia of the Turkish capital would be better for the peace of Europe than her acquisition of Baltic provinces of a purely German character. Moreover, Russia would probably grant facilities for trade and navigation. It

(b) S. Graham, Russia and the World (London, 1915), p. 195.

(c) For example, C. E. Fayle, The Great Settlement (London, 1915), p. 139. 
might even be a question whether Constantinople should not become a free port under the Russian flag, the Dardanelles being neutralised and the fortifications demolished.

Others $(d)$ have proposed that Constantinople should be Constantiplaced under Belgian rule-Belgium being thus singled $\begin{gathered}\text { nople under } \\ \text { Belgian rule. }\end{gathered}$ out presumably because of her martyrdom in the present war.

Whatever advocates there may be of schemes for Mass of assigning Constantinople and the Straits to this or that opinion in Power, there is undoubtedly an overwhelming majority in isation of opinion in favour of internationalisation.

We have already seen that on several occasions in the past the Russian Government and leaders of thought in Russia suggested internationalisation or the establishment of Constantinople as a free port and city: e.g. the proposal of Tsar Alexander to the French ambassador, Caulaincourt, on March 1, 1808; the plan of Count Capodistrias submitted in 1829 to the secret committee for Eastern affairs. We have seen, too, that recent opinion in Russia has been tending in the same direction. But the views expressed in other countries are almost unanimous on the point. A few of these may be referred to.

In 1860 , in view of the conflict that brought the Eastern Question to the front, a Greek, styling himself a 'Constantinopolitain,' issued a pamphlet(e), in which he maintained that the only way to solve this problem and conciliate conflicting interests is to set up Constantinople and adjacent territory as a free republican State, so as to secure free navigation, free trade, and strict neutrality in case of war. The Ottoman Empire should be re-adjusted, so as to separate Christianity from

(d) For example, S. Juge, La paix de 1916 (Paris, 1915), p. 123.

(e) D. Rattos, Constantinople ville libre (Paris, 1860). 
Islamism, and thus end the 'mélange monstrueux' $(f)$. The Sultan would withdraw from Constantinople, and find another capital $(g)$. An Eastern Confederation should be formed, comprising States and territories taken from Turkey, and including Asia Minor and Armenia. 'Quelle route faudrait-il suivre pour arriver, tout en apaisant ces intérêts, de moins en partie, à un état de choses qui gratifie les chrétiens de Constantinople et de l'empire d'un gouvernement plus tolérable que celui des Turcs?... Nous ne voyons qu'une réponse à cette question: Faites de Constantinople une ville libre! Ôtez la pomme de discorde de l'assemblée des États de l'Europe, ils s'entendront, espérons-le du moins, sur le reste. ... Constantinople serait une ville libre; une république . . . avec un gouvernement dans le genre de celui de Hambourg. Ville libre, mais avec la neutralisation du Bosphore et de l'Hellespont, de manière que des fortifications sur ces points fussent rendues inutiles. Ville libre, et port franc, de manière que le commerce $y$ eût ses coudées aussi franches que possible. Avec la stipulation qu'elle ne pourrait jamais faire partie de telle ligne de douane qu'il pourrait plaire aux autres États de la Confédération d'adopter. Libre pour son gouvernement, libre pour son commerce, neutre en cas de guerre' $(h)$. An Eastern confederation of this kind would maintain, more effectively than Turkey, the European equilibrium $(i)$. All States, the writer holds, would derive from such a régime great advantages, religious, commercial, and political.

Efforts of United States to procure passage for warships, 1868-71.
In view of the entry of the United States in the present war, and her consequent concern in the ultimate solution of the Straits question, it is of special interest

(f) D. Rattos, Constantinople ville libre (Paris, 1860), p. 39.

(g) Ibid. p. 31.

(h) Ibid. pp. 27, 28, 38.

(i) Ibid. pp. 41, 42 . 
to recall the position she assumed in 1868-1871 with regard to the existing rule, and the steps taken to secure freedom of passage for all vessels-warships and merchantmen alike-of all nations. In 1868 the House of Representatives passed a resolution requesting the President to instruct the American minister at Constantinople to urge upon the Porte the abolition of the restrictions imposed on the passage of ships through the Dardanelles and Bosphorus, and to endeavour to procure ' the perfect freedom of navigation through those Straits to all classes of vessels.' It appears, however, that the only result of this resolution was the issue of instructions to the minister to obtain for the Department of State full information as to the prevailing restrictions $(k)$. The Russian Government was subsequently informed that, though it was doubtful whether the President would take the initial step conformably to the resolution, the United States was ' in principle and by habit favorable to the largest freedom of navigation and commerce compatible with the rights of individual nations,' and would 'favor the removal of the restrictions upon the navigation of the Bosphorus and the Dardanelles within the limits of international law' $(l)$. Soon after the conclusion of the Treaty of London, March 13, 1871, the United States Government intimated to the Porte (May 5, 1871) that-it did not question the propriety of excluding vessels from the Straits, but it did.not recognise the practice as a right under the law of nations. Turkey's position in regard to the Black Sea was compared with Denmark's in regard to the Baltic, except that both sides of the Straits belonged to Turkey, whilst

(k) Mr. Seward, Secretary of State, to Mr. Morris, Minister to Turkey, July 11, 1868 : MS. Instructions to U. S. Ministers, Turkey, ii. 21 ; Moore, Digest of international law, vol. i. pp. 665, 666.

(l) Mr. Seward to M. Stoeckl, Russian minister, October 5, 1868 : MS. Notes to Russian Legation, vi. 273 ; Moore, op. cit. vol. i. p. 666. 
Sweden owned the territory on the east of the Sound leading to the Baltic. After referring to the abolition of the Sound dues, the American Secretary of State observed: 'We are not aware that Denmark claimed the right to exclude foreign vessels of war from the Baltic merely because in proceeding thither they must necessarily pass within cannon-shot of her shores. If this right has been claimed by Turkey in respect to the Black Sea, it must have originated at a time when she was positively and comparatively in a much more advantageous position to enforce it than she now is. The Black Sea, like the Baltic, is a vast expanse of waters which wash the shores not alone of Turkish territory, but those of another great Power who may, in times of peace at least, expect visits from men-of-war of friendly States. It seems unfair that any such claim as that of Turkey should be set up as a bar to such an intercourse, or that the privilege should in any way be subject to her sufferance' $(m)$. Again, on January 3, 1873, the United States Secretary of State wrote: 'The abstract right of the Turkish Government to obstruct the navigation of the Dardanelles even to vessels of war in time of peace is a serious question. The right, however, has for a long time been claimed and has been sanctioned by treaties between Turkey and certain European States. A proper occasion may arise for us to dispute the applicability of the claim to United States men-of-war. Meanwhile it is deemed expedient to acquiesce in the exclusion' $(n)$.

Coming now to more recent expressions of opinion,

(m) Mr. Fish, Secretary of State, to Mr. McVeagh, minister to Turkey, May 5, 1871 : Foreign relations of the United States, 1871, p. 902 ; Moore, op. cit. vol. i. pp. 666, 667.

(n) Mr. Fish, Secretary of State, to Mr. Boker, minister to Turkey, January 3, 1873: MS. Instructions, Turkey, ii. 452; Moore, op. cit. vol. i. p. 667 . 
we find, in 1905, a French writer (o) emphasising that, of passage, owing to the fact that Roumania and Bulgaria possess isation, etc. coasts on the Black Sea, the right of passage through the Bosphorus and the Dardanelles no longer concerns Turkey and Russia exclusively. Other States possess now a legitimate title to intervene in the old RussoTurkish quarrel ; and it would be ' une iniquité flagrante' to refuse their warships the right of passage between the Black Sea and the Mediterranean. It has therefore become all the more necessary to effect an equitable regulation of the question. And this can well be done by applying to the Straits the régime of the Suez Canal. But to make such solution a success, it is indispensable that the Great Powers should abandon whatever secret designs they may have in regard to exclusive domination over the Straits.

Others $(p)$ maintain, too, that whatever sovereignty be established in Constantinople, the Bosphorus and the Dardanelles, instead of being closed to foreign warships, should be opened to the vessels of all kinds of every nation. This change could be made on the basis of the Convention of Constantinople of 1888, which provides for the status of the Suez Canal. The assimilation is quite feasible, inasmuch as the Turkish Straits are so narrow that they may logically be considered in the same class with such artificial waterways as canals.

M. Hanotaux $(q)$ holds that on the whole the simplest, the widest, the most modern, and the best solution is to allow free passage to all vessels. But he does not suggest any particular régime, such as that of the Suez Canal.

Another proposal is to apply the rules of the Straits

(o) R. Pinon, Revue des deux mondes, October, 1905, p. 823.

(p) For example, M. Lozé, La question des Détroits (Paris, 1908), p. 118 ; Dascovici, op. cit. p. 292.

(q) Introduction to Goriainow, op. cit. p. xvii. 
of Magellan, whereby no fortifications or military works are to be maintained or established. And as for Constantinople, an international system, like that of Tangiers, is suggested $(r)$.

'Constantinople,' says another writer, 'a town essentially cosmopolitan and in reality but little Mussulman, shall receive a special status under international control, and thus will disappear-at least in its old form-this Eastern Question which has made so much ink and blood flow. . . . Constantinople cannot be assigned either to a great Power or to a small Power' $(s)$.

A Swiss Committee, having studied the principles of a durable treaty of peace, came to the conclusion that it would be in the general interest to neutralise not only the Bosphorus and the Dardanelles, but also all specially contested territories, including various Straits $(t)$.

Straits Territory under military guardianship of United States.
A more elaborate scheme was presented in 1915 by an English writer $(u)$ who suggested that Constantinople and the surrounding territory (which he carefully marked out) should be set up as an independent State with local autonomy and an international military administration. He points out that the population of the delimited territory is diverse in nationality: the peasants of the Troad are for the most part Turks; the inhabitants of the islands (whose area, however, is comparatively very small) are of Greek origin; and the population of Constantinople is cosmopolitan in character-the estimated total of 874,000 being divided up approximately as follows : 385,000 Moslems, 153,000 Greeks, 150,000 Armenians, 129,000 foreign subjects, 44,000 Jews, and 13,000 others. The

(r) J. Aulneau, La Turquie et la Guerre (Paris, 1915), p. 329.

(s) P. Louis, L'Europe nouvelle (Paris, 1915), pp. 29, 30.

$(t)$ Memorial concerning the principles of a durable treaty of peace (Olten, 1915), p. 54. seq. 
present Turkish superiority in numbers is "largely artificial' $(x)$, being due, on the one hand, to the official circles and retired official circles with their immense households, and, on the other, to the numerous - dock labourers. The latter constitute a transient element, and the former would migrate with the Ottoman Government to its new capital. The Mussulman majority being thus greatly reduced, the Greek element would probably preponderate in the Straits Territory, and so would there set up an autonomous republic, with Greek as its official language. Having thus disposed of the civil administration, the writer considers the military aspect. Various suggested solutions are considered, and their difficulties pointed out. Thus, if the fortifications are demolished and no military force is maintained, the Straits Territory would succumb to the first invader. Military organisation is therefore essential; but to place it in the hands of the native Greek population 'would be to invite a coup d'etat'-there would always be the danger that the republic would unite with Greece $(y)$. Accordingly a foreign military administration appears to be requisite. Three plans may be suggested for establishing this. (1) Garrisoning the territory with composite forces drawn from the European Powers. There are recent instances of international co-operation, e.g. the occupation of Crete by four Powers, 1897-1909; the joint expedition to China, 1900, in the case of the Boxer rising; the establishment of the 'zones of inspection' in Macedonia, 1904-8; the despatch of the naval landing-parties to Skodra, 1914. But these examples of conjoint action are not strictly analogous, inasmuch as the object in each case was of a temporary and limited character. Moreover composite garrisons would be lacking in perfect 
allegiance and common spirit.

(2) Hence, homogeneity seems to be indispensable; and the problem is how to secure it. To recruit citizens from the various European Powers, offer them a life-long career, and build up a service 'with a tradition and a professional pride of its own,' would probably turn out a failure, like the French foreign legion in North Africa, and the 'Papal Zouaves' in the middle of the nineteenth century. (3) And so, by this process of elimination, one course remains, viz. to call on some existing national State to assume the military custody of the Straits Territory. The Great Powers of Europe being ruled out ex hypothesi, and analogous attempts of minor Powers, e.g. in Persia and Albania, having proved unsuccessful, the last resort then is to appeal to the United States of America, whose acceptance of the burden would be an act of 'international generosity,' and an earnest of universal peace (z). 'The task of the United States is to come to an end, when Europe ' has built up among her various nationalities that common European patriotism which alone can give her the spiritual force to administer the trust herself. . . Europe can only be saved by her own efforts' $(a)$.

Sir Edwin Pears, one of the greatest British authorities on conditions in the near East, maintains (b) that the only guarantee of a durable peace is the establishment of a free, international Constantinople. The Bosphorus must be open to all ships of all nations. He suggests that a small independent State (whose limits he indicates), with Constantinople as its centre, should be formed; it should remain neutral for ever, and should be governed by an International Commission, without any individual ruler whatever. This neutral, independent State should 376.

(z) A. J. Toynbee, Nationality and the War (London, 1915), pp. 375,

(a) Ibid. p. 378.

(b) See article by Noel Buxton in Contemporary Review, June, 1917. 
possess no army, but only an efficient police to preserve order; and its integrity should be guaranteed by 'enduring and binding' treaties entered into by all the Powers.

The plan for internationalisation is adopted by several other recent writers $(c)$.

With regard to Turkish views, we may refer to the following statement that appeared in the press in May, $1917(d)$ : 'Reuter's Agency is officially informed that numbers of Turks and Turkish agents are at work in Switzerland with the object of assuring the continued existence of Turkey in Europe. These agents are making it understood that, provided the Turks are not driven out of Constantinople, they are willing to allow complete freedom of the Dardanelles to all comers.'

(c) For example, P. Otlet, Les problèmes internationaux et la guerre (Genève, Paris, 1916), p. 478 ; H. N. Brailsford, A league of nations (London, 1917); L. S. Woolf, The Future of Constantinople (London, 1917).

(d) See Daily News, May 10, 1917. 


\section{CHAPTER IV.}

\section{WHICH IS THE BEST SOLUTION?}

Various solutions suggested.

The old rule no longer tenable.

As we have seen, various plans have been suggested for solving the Straits problem, e.g. (1) Constantinople to be handed over to Russia; (2) Constantinople to be a free port under the Russian flag; (3) Constantinople to be placed under Belgian rule; (4) Constantinople and district to be established as an autonomous State, whose civil administration to be in the hands of the local Greek population, and the military guardianship to be temporarily in the hands of the United States ; (5) Constantinople to be a free town and port under the collective guarantee of the Powers; (6) as for the Straits, freedom of passage to be granted to all vessels of all nations, Turkish control remaining; (7) the Straits to be handed over to Russia; (8) the Bosphorus to be given to Russia, and the Dardanelles to another Power; (9) the Black Sea to be made a Russian lake; (10) the Straits to be internationalised, and a régime similar to that of the Suez Canal or the Panama Canal to be set up.

It is obvious that the old rule of the Straits can no longer be allowed to prevail. On several important grounds a substantial modification has become indispensable, indeed inevitable. The preceding chapters have shown clearly the ill effects of the application of this precarious and sinister 'ancient rule of the Ottoman Empire'-the diplomatic intrigues, the design of this or that Power to acquire predominating influence in Turkey, the political combinations consequent on the uncertain shifts and turns of national policy and State 
interest, the jealousies and hostilities of States, the repeated menaces and interventions, the open conflicts and disastrous wars, the incalculable loss of lives and treasure. Further, the old rule must be changed because Turkish control over the Straits is no longer acceptable, in that the Ottoman Government deliberately violated its own solemn engagements towards the Powers by admitting foreign warships (viz. the Goeben and Breslau) into the Dardanelles, and aiding and abetting them in their operations against States (e.g. Great Britain and France) with which it was not at war at the time. Again, revision is necessary because the old rule is for Russia arbitrary and obnoxious, inflicting an insufferable hardship on her, by imprisoning her Black Sea fleet; we need only recall the pitiful position in which she found herself during her war with Japan, when, unable to make use of some of her best warships, she had to meet a powerful adversary with one of her arms tied.

No wonder, then, that the Straits régime has failed Why the utterly. Ostensibly it was based on a series of inter- has failed. national engagements, which were sufficiently general to make us consider the rult of the Straits as a part of European public law, if not of general international law. But to construct an edifice on a crumbling foundation is to invite disaster. The basis on which the rule was established was no more than a shifting sandbank,-for its execution depended on the apparent discretion of a Government whose methods were ever tortuous, whose hostility to the Christian Powers and their subjects is inveterate, whose incompatibility with the European State system is manifest, and-to do it justice-whose policy.and counsels swayed this way or that according as one Power or another acquired a preponderating influence over it. It is through attempting to build law on an unstable foundation and making it dependent on 
the machinations of diplomacy that even the most unsophisticated minds come to entertain a contempt for international law. The true object of diplomacy is surely to bring about an amicable rapprochement between governments and nations, to establish salutary relationships between them on the basis of fairness, goodwill, and right understanding, to promote the permanent interests of peoples; instead of this, the object in the past appears to have been to sow dissension between emulous nations and mutually distrustful governments, and to advance the temporary interests of the few at the expense of the many, to create excuses for evading obligations imposed by treaties. And nowhere has this noxious diplomacy manifested itself more conspicuously than in its application to the Straits question. 'Aucun code international,' truly says a writer already referred to, ' ne règle l'ouverture ou la fermeture des détroits; ; ce sont les intérêts des forts qui en décident; or ces intérêts sont complexes, parfois contradictoires, et ils varient selon les temps et les circonstances. . . . . Ainsi les traités ont créé un droit international, mais les grandes puissances intéressées n'en ont, en pratique, requis l'application que lorsqu'elles étaient sûres d'être elles-mêmes assez fortes pour en transgresser impunément les règles ' $(a)$.

In reference to an expression in a British parliamentary paper to the effect that international law will contribute to the security of this country by imposing restrictions on the operations of its enemies, the same writer reproaches us for bending international law to our interests and varying policy, and for using our diplomacy for the purpose of attaining our own private object: '. . . . Il est impossible,' he observes, 'de reconnaître avec plus de bonne grâce que les règles du droit international doivent

(a) Pinon, Revue des deux mondes, October, 1905, p. 804. 
se plier aux exigences des intérêts anglais; telle est la méthode du Foreign Office; en invoquant les principes supérieurs de la justice et du droit, il a eu l'art incomparable de faire promouvoir au rang de vérités intangibles ce qui n'était, le plus souvent, pour lui, que l'expédient temporaire d'un politique dans l'embarras. La répression de la traite des nègres lui a servi jadis à prétendre au "droit de visite," qui n'était qu'un procédé vexatoire pour affirmer la suprématie maritime de la GrandeBretagne; et, pour ne citer qu'un autre exemple, on n'a pas oublié comment, à la faveur de la guerre russojaponaise et de l'incident de Camranh, il a tenté de nous imposer des règles de neutralité conformes aux intérêts anglais et contraires aux nôtres. . . . . En Orient, à propos des détroits et de la liberté de la Mer Noire, il a usé de ce procédé, avec une habileté supérieure, pour le plus grand avantage de sa politique '(b). Undoubtedly the diplomacy of no State has in the past been above suspicion; but we may justifiably flatter ourselves in believing that if the diplomacy and the proceedings of every State had been no worse than our own, the present convulsion in the world would not have taken place.

However this may be, the Straits problem is now The problem different from what it has been in the past; and a brief of the Straits consideration of its present character will help us to decide as to the best solution applicable in the circumstances.

In the first place, the striking economic development of Russia during the last twenty years or so has emphasised more than ever the necessity of possessing maritime outlets in the south and the right of unimpeded navigation from the Black Sea through the Straits to the 
Mediterranean. In 1902 a Russian industrial mission reported on the importance of the Bosphorus to the commercial life of Russia : from time immemorial it has been a centre of world commerce, and, owing to its geographical position, it is an inevitable gate in the orbit of expansion of southern Russia (c). The great part that maritime transport plays in the economic and industrial life of Russia is seen from the following table $(d)$ for the year 1913 :-

\begin{tabular}{|c|c|c|c|c|}
\hline & \multicolumn{2}{|c|}{ ExPORTS. } & \multicolumn{2}{|c|}{ IMPORTS. } \\
\hline & $\begin{array}{l}\text { Thousands } \\
\text { of tons. }\end{array}$ & $\begin{array}{l}\text { Millions } \\
\text { of francs. }\end{array}$ & $\begin{array}{l}\text { Thousands } \\
\text { of tons. }\end{array}$ & $\begin{array}{l}\text { Millions } \\
\text { of francs. }\end{array}$ \\
\hline Black Sea and Sea of Azof & $. .11,086$ & $1,286 \ldots$ & . 921 & 247 \\
\hline Baltic Sea $\ldots \ldots \ldots \ldots \ldots$ & .. 5,857 & $1,227 \ldots$ & 7,515 & 1,299 \\
\hline Caspian Sea..... & .. 143 & 77. & 123 & 67 \\
\hline White Sea ...... & .. 1,506 & $97 .$. & 128 & 15 \\
\hline Pacific Ocean .... & . . 61 & 12. & 351 & 183 \\
\hline Total by sea... & $. .18,653$ & $2,699 \ldots$ & 9,038 & 1,811 \\
\hline Total by land . & . 5,581 & $1,355$. & 6,316 & 1,853 \\
\hline Grand total & $.24,234$ & 4,054 & 15,354 & 3,664 \\
\hline
\end{tabular}

This table shows the preponderating amount of Russia's sea-borne trade, and the supreme position occupied therein by the Black Sea and the Sea of Azof, whose outlet is the Bosphorus and the Dardanelles. During the years 1901-1910, the southern ports of Russia exported nearly! nine-tenths of the total quantity of wheat, barley, rye, and maize (e). Many other important articles of commerce are exported from Odessa and Rostoff, in exchange for goods imported from the Mediterranean through the Straits. It is obvious, then, that the Power in exclusive possession of the Bosphorus

(c) Quoted by Hoschiller, op. cit. p. 95.

(d) Ibid. p. 99.

(e) Cf. G. Alexinsky, Russia and the Great War, pp. 23, 24, who refers to the work of the Russian economist M. A. Finn-Yenotaevsky, Sovremennoïe Khoziästov Rossiyi (The modern economy of Russia) (Petrograd, 1911), pp. 425, 426. 
can, at its discretion, put a stop to the whole of this gigantic trade, and so bring disaster on the agricultural life of Russia, and impose great hardships on several European nations, e.g. Italy, France, Holland, Belgium, England, Germany, who to a large extent depend on Russian produce for their provisioning. Thus, as soon as Turkey became a belligerent in the present war and closed the Straits to Russian shipping, the effect was at once acutely felt not only in Russia, but also in several countries of Europe : in 1915, for example, Russia exported only about one-fifteenth part of the quantity of wheat she exported in $1914(f)$. And not only is her agriculture involved; the extensive industries of her provinces adjacent to the Black Sea also depend largely on the freedom of the Straits $(g)$. It follows, therefore, that such a change in the Straits régime is essential as will make interference with Russian shipping impossible.

But here the question arises whether this change can Whether best be effected by placing Constantinople and the Bos- $\begin{gathered}\text { Russian } \\ \text { posssion of }\end{gathered}$ phorus in the hands of Russia. Most probably the sub- advisable. stitution of Russian administration for Turkish would prove beneficial to commercial navigation generally, and would assure its liberty and its interests more effectively than under Ottoman rule $(h)$; the Mediterranean trade would thereby receive a great impetus. But a solution of this kind is not a general solution. There is not and cannot be a certain and reliable guarantee that Russia or any other single Power that was in exclusive possession of the Straits would not, in case of emergency, impose restrictions on or even entirely exclude foreign shipping, in the interests of ' national necessity' or 'State policy.' That Russia should gain possession of Constan-

(f) Ibid. p. 105.

(g) Ibid. pp. 105-108.

(h) Cf. Russkoie Slovo, cited by Corriere della Sera, April 1, 1915. 
tinople for religious reasons or through traditional considerations is an untenable argument at this time of day. If historic pretensions to the Byzantine succession are to have any validity at all, then it would seem that the claims of Greece and Italy are on such grounds superior to those of Russia. The settlement of the question, then, cannot be based on a one-sided view; if it is to be durable and satisfactory, it must be compatible with the interests generally of the whole society of nations, and more particularly with the interests of the European circle of States. The exclusive possession by any one Power of such international waterways as the Bosphorus and the Dardanelles is really contrary to the fundamental principles of international law and usage. Moreover, the occupation of Constantinople by Russia would even prove to be a danger to herself. Regard must be paid to the mixed character of its population, and to the fact that it includes at present very few Russians. Further, the southern Russians are in many respects different from the northern; and, considering the political movement that has for some time been progressing in Russia, the establishment of a southern capital might well lead eventually to a dismemberment of the Empire, to a secession of the southern provinces, to conflicts and again to territorial scrambles. Such a condition of things would undoubtedly be taken advantage of by the Central Empires, whose interests in the Near East could never be obliterated. An opportunity would also be afforded to the Balkan States, which might be led to form an alliance with Germany and Austria-Hungary, in order to further their growing aspirations. And so alliances and counter-alliances would be established once more, the interests of this group of Powers would be found to be opposed to those of that group, and hostility and war would again be the inevitable result. Nor would the 
internationalisation or 'neutralisation' of the Straits under Russian sovereignty be a satisfactory solution; Europe could not become reconciled thereto; for there is a widely prevailing fear that the Russian administration of the Bosphorus and the Dardanelles would turn out to be something quite different from that of England in the case of Suez Canal, and from that of the United States in the case of the Panama Canal $(i)$. Modern Europe is in reality as much opposed as Napoleon was to the possession of Constantinople and the Bosphorus by Russia. Napoleon is reported by Las Cases to have said: 'L'idée de chasser les Turcs de l'Europe me sourit, mais je savais ce que valait la possession de Constantinople, et j'ai abandonné l'empire de la moitié du monde, plutôt que de donner à la Russie ce mince détroit.'

Another important point to be borne in mind is the other Powers fact that Russia is not the only Power on the Black Sea. direotly concerned. Apart from Turkey-whatever be her destiny-Roumania and Bulgaria cannot equitably and juridically be eliminated from any attempted solution of the Straits question as it exists now. There is no necessity at this time of day to emphasise the desirability of permitting small States, represented by fairly homogeneous nationalities, to retain their autonomy and independence and continue to exist according to their local needs and their national and political ideals. The intervention of the Great Powers in their affairs may perhaps be justified in certain cases, e.g. in order to prevent a breach of international law, or the continued commission of barbarous crimes against civilisation; but the Great Powers are not legally entitled to dispose of their destiny at discretion.

(i) Cf. Dascovici, op. cit. p. 294 : 'Après le développement de la politique russe on Orient, nous avons non-seulement la crainte, mais la certitude, qu'une administration russe aux détroits, instaurée pour le plus grand bien de la Russie, sera fort différente de celle de l'Angleterre au canal de Suez et de celle des Etats-Unis au Panama." 
International commerce in the Straits.
Now from a commercial point of view the Bosphorus is not only a natural extension of the mouths of the Dnieper, Dniester, and Don, but is also just as natural a reservoir of the Danube, and of the Roumanian ports and mercantile establishments situated on the south coast of the Black Sea. At Galatz, Braila, and Constanza, great quantities of Roumanian wheat are exported to western Europe-indeed, 95 per cent. of the total exports of Roumania (including cereals, petrol, salt, wood) is sent by sea; Rodosto in Bulgaria is the outlet for the rich districts surrounding Chorlu and Lule Burgas; whilst Trebizond is the outlet whereby the commerce of western Europe is extended to the markets of the north-east of Asia Minor, to those of Armenia, and the north-west of Persia $(j)$. The Black Sea is thus in the position of an open sea, and the commerce passing through the Bosphorus is of an international characterit is by no means confined to the Russian, Turkish, Roumanian, and Bulgarian flags. Indeed, the shipping there of at least three other States is of greater magnitude than the Russian, and far greater than that of the other littoral countries. In 1911 the number of vessels that passed the Bosphorus was 34,562 with a total tonnage of $19,968,409$; in 1912 there were 34,577 , with a total of $15,298,537$; and 1913 there were 34,826 vessels, with a total tonnage of $13,412,065$. This enormous commerce was divided among the different countries as follows $(k)$ :-

Flag.

Tonnage.

Percentage of Total.

1. English .......

2. Greek ..........

3. Austro-Hungarian

$5,370,781$

$37 \cdot 5$

$42 \cdot 3$

1911.

4. Russian ........

$16 \cdot 4$

43.5

$1,958,201 \quad \ldots \quad 13 \cdot 7$

11

$15 \cdot 3$

$1,615,293$

.. 11.3

$9 \cdot 7$

$1,428,435$

.. 10

6.5

$6 \cdot 4$

(j) Hoschiller, op. cit. p. 112.

(k) Revue commerciale du Levant, vol. xxviii. (1914), p. 300. 


\begin{tabular}{|c|c|c|c|c|c|}
\hline Flag. & Tonnage. & & $\begin{array}{l}\text { Perc } \\
1913 .\end{array}$ & $\begin{array}{l}\text { ge of Total. } \\
1912 .\end{array}$ & 1911. \\
\hline 5. Turkish ....... & 906,416 & .. & $6 \cdot 3$ & 5 & $4 \cdot 1$ \\
\hline 6. German ........ & 733,600 & .. & $5 \cdot 1$ & $3 \cdot 8$ & $3 \cdot 7$ \\
\hline 7. French $\ldots . .$. & 572,730 & .. & 4 & $3 \cdot 3$ & $3 \cdot 3$ \\
\hline 8. Italian .......... & 370,302 & .. & $2 \cdot 6$ & $3 \cdot 8$ & $6 \cdot 2$ \\
\hline 9. Roumanian ...... & 350,173 & .. & $2 \cdot 4$ & $1 \cdot 9$ & $1 \cdot 6$ \\
\hline 10. Belgian ........ & 295,038 & . & 2 & $1 \cdot 6$ & 1 \\
\hline 11. Norwegian ...... & 288,203 & .. & 2 & $1 \cdot 3$ & - \\
\hline 12. Dutch ......... & 199,034 & $\ldots$ & $1 \cdot 4$ & $1 \cdot 1$ & $1 \cdot 6$ \\
\hline
\end{tabular}

\section{Spanish, \&c.}

This table shows that nearly all the countries of Europe are interested in the navigation of the Bosphorus and the Dardanelles, and that therefore neither a Russian nor a Balkan solution of the Straits question could possibly be a satisfactory one to Europe in general.

Furthermore, every independent State on the Black Protection of Sea is entitled, in principle, to maintain naval establish- Black Sea. ments on its shores and warships in its waters for purposes of police and self-protection. And all such vessels should enjoy perfect freedom of navigation in the Straits, subject to whatever local regulations may be necessary for ensuring order and the convenience of all. Great Britain and France have no longer the same reasons as they had formerly for opposing the passage of Russian warships from and to the Black Sea. Before the Crimean War, for example, Russian and Ottoman territory were adjacent, so that there might well be a reasonable fear that, when a suitable opportunity arose, Russia might swoop down on Turkey and seize a portion of her possessions adjoining the Straits. Now, however, Roumania and Bulgaria, as independent States, being themselves interested in the navigation of the Bosphorus, serve as intermediate barriers; hence the maintenance of equilibrium on the Black Sea is now more assured.

It follows from the above considerations that, what- Opening of ever particular form the solution of the Straits question as the 

fundamental may take, it must incorporate as the fundamental prin-
principle.

ciple the freedom of navigation for the warships, as well as for the merchantmen, of all nations, in time of war as in time of peace. 'Si l'on aborde audacieusement,' observes M. Clémenceau ( $l$ ), 'la transformation de l'Europe et de l'Asie par l'ouverture du canal de Suez, comment fermer les canaux que l'innocente nature a formés?'

The principle of opening the Bosphorus and the Dardanelles is from every point of view a more salutary one than that of closing them. Indeed, the principle of closing has never been in the past, and certainly cannot be at present, an absolute principle. Under the Treaty of London, July 13, 1841, certain exceptions were admitted, viz. in reference to the passage of light vessels; and under the Treaty of London, March 13, 1871, the more important exceptions introduced, whereby the Sultan obtained a discretionary power to open the Straits to any warships he chose for the purpose of enforcing treaty stipulations, ended by destroying the principle. In the negotiations at Vienna for the termination of the Crimean War Prince Gortchakoff suggested in April, 1855, that the Straits should be opened to all vessels, but the suggestion was peremptorily rejected by Lord Palmerston. Had the proposal, however, been accepted the resulting régime would not have been found intolerable by Russia; it would not have involved, as did the sinister arrangement of 1856 , an unnatural restriction on her inherent right of sovereignty, and an attack on her national dignity and self-respect; and so the unilateral denunciation of a treaty would not have occurred, and the rule of 1871, whose interpretation was ambiguous and application precarious, would not have 
been established, and diplomatic conflicts and international animosity would have been avoided.

The freedom of the high seas and that of natural channels connecting them is a sine qua non of any rational system applicable to the relationships of States. It is indispensable to their free development, their prosperity, their fellowship and solidarity. To interfere with that freedom, to impose factitious restrictions thereon, may at certain times appear to be advantageous to this or that State; but in the long run such a policy is sure to prove obnoxious to the international community at large, and a danger to the very Power or Powers that had been instrumental in bringing it about. As one of the most eminent of Russian jurists well says: 'Le principe de la liberté des mers découle de la communauté et de la solidarité des intérêts de toutes les nations. Il a été étabii, non par la nature, mais par le consentement de tous les peuples. Ils ont compris que la mer était leur lien naturel et que sa liberté assurait leur prospérité et le développement de leur situation comme membre de la communauté internationale. C'est pourquoi toute entreprise contre cette liberté est un attentat aux droits imprescriptibles des nations, une menace contre tous les États. Aussi leur résistance commune à une pareille violation du droit est-elle parfaitement légitime' $(m)$. That the nations of the world are necessarily interdependent is a vital truth which the present war has clearly demonstrated. The independence of States, so far as their autonomy and internal arrangements are concerned, may well be jealously guarded; but to insist on it is perfectly compatible with the recognition of the interdependence of nations. National virtues may be cultivated, without engendering international antagonisms.

(m) F. de Martens, Traité de droit international. Fr. trans. (Paris, 1883), vol. i. p. 492. 
The isolation of States leads to antipathy and hostility, as well as to intellectual and material impoverishment; on the contrary, close association, economic and political, cemented by common principles and common laws universally recognised as supreme and inviolable, breeds understanding, harmony, and peace, and promotes the true interests of civilisation in general.

How liberty of navigation to be established.

The best mode of establishing this liberty of navigation in the Bosphorus and the Dardanelles, as in all other Straits connecting the high seas, is by applying the system of internationalisation; and the most desirable system of internationalisation is that which is secured by the joint guarantee and protection of the Powers. There are obviously serious disadvantages in the proposal to place the Straits of Constantinople under the civil administration of one nation and under the military guardianship of another. And to assign the latter to a nonEuropean Power, such as the United States, is to increase the dangers and difficulties $(\mathrm{mm})$. The problem is mainly a European one: to abandon it to a nonEuropean Power is not to solve it, but to shirk it. The most rational, judicious, and practicable solution is to internationalise the Bosphorus and the Dardanelles on the lines of the regime applied to the Suez Canal, and place them, together with sufficient hinterland to safeguard the strategic position, under the administration of an International Commission somewhat similar to that which has existed in the case of the Danube. A system of internationalisation means international co-operation. It is, then, manifestly in the interests of the world at large that every opportunity

$(\mathrm{mm})$ The reasons against the assignment of such functions to the United States, being for the most part founded on the Monroe doctrine, are now less potent in view of her present close association with Europe and the grounds declared by her for participating in the War. 
should be seized for internationalising territories that have given rise to inveterate disputes, as well as waterways that are used for general international commerce and intercourse. To bring about the co-operation of States in this or that undertaking is to promote the habit of association, and to pave the way for a more thorough and comprehensive union, such as is implied in the establishment of a League of Nations subject, in the event of differences, to the arbitrament of an International Court.

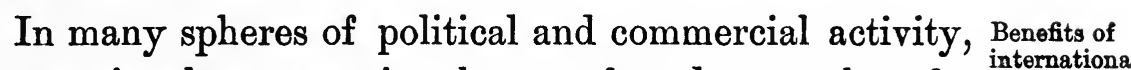
international co-operation has conferred great benefits co-operation. on all parties concerned. Thus-to name but a few examples-the Congress of Vienna, 1815, established freedom of navigation on the great European rivers; the Treaty of Paris, 1856 , applied the principle to the Danube; the West African Congress at Berlin, 1885, secured commercial liberty within the basin of the Congo, and free navigation on the Congo and the Niger, and created the International Congo Commission, analogous to the Danube Commission; it put a check to the slave trade, neutralised the territory of the Congo Free State, and laid down rules relative to the occupation of new territory on the coasts of Africa; the Treaty of Constantinople, 1888, provided for the free navigation and permanent internationalisation of the Suez Canal; the Brussels Conference, 1890, agreed upon measures for suppressing the African slave trade, and for restricting the trade in spirituous liquors in certain parts of Africa. Again, various common interests have been successfully regulated and managed by general unions, e.g. for postal communication, telegraphic communication, protection of industrial property (including patents, trade-marks, and designs), protection of copyright in works of literature and art; other unions are the sugar union, the 
customs tariff union, the railway traffic union, the Latin monetary union. Further, by means of international co-operation, fisheries outside territorial waters have been regulated, the practice of extradition has been established, and many other matters, economic, social and sanitary, have been amicably settled. More than thirty public international unions have been set up, many of which possess permanent organs of administration and legislation. It is not our purpose here, however, to go into this question of international administration in general, and into the numerous applications thereof $(n)$; our object is to emphasise that in many branches of international relationships co-operation has already proved an inestimable blessing, and that it can well be adopted in other spheres for the common good of the family of nations. Apart from co-operation of this kind, there have also been recently several instances of conjoint action of the Powers for temporary and urgent purposes in regard to territories outside their own countries and subject to other Sovereigns; e.g. the international administration of the Ottoman debt; the pacific blockade of the coasts of Greece by the Great Powers (excepting France) in 1886, in order to prevent the Greeks from making war on Turkey and so precipitating a general European conflict $(0)$; the joint occupation of Crete by four of the Powers; the common expedition (including the United States) to China in the case of the Boxer rising, 1900 ; the establishment of 'zones of inspection' in Macedonia, 1904-1908; the despatch of the naval

(n) The reader interested in the subject will find the following works useful: L. Poinsard, Les unions et ententes internationales (Paris, 1901); C. Van Overbergh, L'association internationale (Bruxelles, 1907); P. S. Reinsch, Public international unions (Boston; London, 1911); L. S. Woolf (Ed.), International government (London, 1916).

(o) For various instances of combined intervention by the Powers, see C. Phillipson, Termination of war and treaties of peace (London, 1916), pp. 75 seq. 
landing parties to Skodra, 1914, in order to establish order in Northern Albania. We know that the efforts in Macedonia did not prove successful; but this failure need not discourage us, as we may set against it scores, even hundreds, of examples of successful co-operation.

The internationalisation of the Bosphorus and the InternationalDardanelles as suggested above, does not necessarily istion and amount to neutralisation. The latter word is frequently used in reference to the Suez Canal ; but, strictly speaking, it is not correct, inasmuch as the passage of belligerent warships is permitted, whilst in neutralised territory the passage of belligerents' forces is prohibited. Lord Cromer, speaking of the term 'neutralisation' as applied to the Suez Canal, cited Lord Pauncefote as saying that it 'had reference only to the neutrality which attaches by International Law to the territorial waters of a neutral State, in which a right of innocent passage for belligerent vessels exists, but no right to commit an act of hostility' $(p)$. On the basis, then, of the régime established for the Suez Canal by the Treaty of Constantinople, October 29, 1888 (which is followed almost entirely by the convention relative to the Panama Canal) the following principles, including special provisions submitted by the present writer, may well be applied to the Straits of Constantinople, thus assimilating their international status-so far as those principles go-to that of the great interoceanic canals:-

1. The Straits to be free and open on terms of equality Principles to the merchantmen as well as to the warships of all suggested for nations, in time of war as in time of peace $(q)$.

(p) Modern Egypt, 2 vols. (London, 1908), vol. ii. p. 384.

(q) The Hay-Pauncefote Treaty of 1901, between Great Britain and the United States, providing for the navigation of the Panama Canal, omits the phrase 'in time of war as in time of peace,' which is found in the Suez Canal Convention. It would follow, therefore, that a reservation is implied, whereby the United States remains empowered 
2. Blockade to be prohibited.

3. No act of war or hostility to be committed within their waters, or in the Sea of Marmara, or within a radius of three marine miles in the Mediterranean on the one hand, and in the Black Sea on the other.

4. No mines or torpedoes to be placed within their waters, or in the Sea of Marmara, or within a radius of three marine miles in the Mediterranean on the one hand, and in the Black Sea on the other. If mines or torpedoes are placed in adjacent territorial waters, precise instructions to be issued to shipping.

5. The existing fortifications to be demolished, and the erection of other permanent fortifications to be forbidden.

6. The plant, establishments, buildings, \&c. relating to the navigation of the Straits to enjoy at all times immunity from attack or injury from all such acts as are calculated to impair their usefulness.

7. No belligerent warship to re-victual or take on stores in the Straits, in the Sea of Marmara, or within three marine miles of either end, save so far as may be strictly necessary; and the transit of such vessels through the Straits to be effected with the least possible delay conformably to the regulations in force, and with only such intermission as may result from the necessities of the service.

8. Prizes to be subject to the same rules as belligerent warships.

9. No belligerent to embark or disembark troops, munitions of war, or warlike material in the Straits, in the Sea of Marmara, or within three marine miles of either end, save in case of accidental hindrance of the

to close the canal during a war, if so found necessary for her selfprotection. 
transit, and in such cases the transit to be resumed with all possible dispatch.

10. No belligerent warship to remain in the said waters longer than twenty-four hours at any one time, except in case of distress, and, in such circumstances, to depart as soon as possible.

11. If vessels belonging to different belligerents find themselves in the waters or ports of access at the same time, then an interval of twenty-four hours to elapse between the departure of any vessel belonging to one belligerent and that of any vessel belonging to the other.

12. No men-of-war to be stationed within the said waters, but each Power, not being a belligerent, to be entitled to station there two light vessels for the use of its representatives at Constantinople and for police purposes.

13. Immunity from attack or other warlike operations to be conferred on a strip of territory surrounding the Straits, for the purpose of assuring the protection of the latter.

14. These provisions to be carried out by a permanent International Commission sitting at Constantinople; and the latter to be empowered to make additional regulations for the purpose of facilitating navigation, policing the waters, quarantine, and ensuring good order.

15. Differences between the Powers in respect of the application or interpretation of any provision relative to the Straits to be settled by the International Commission, or, in default, by arbitration in accordance with the principles set forth at the Hague Conference.

The constitution of the International Commission for International the Straits may well be modelled on that of the European Commission. Commission for the Danube, which has achieved such success that it may be regarded as a remarkable precursor in the art of international government The 
establishment of the institution is, indeed, attributable to the recognition of the principle, emphasised by Grotius $(r)$ and expounded more fully by Vattel $(s)$ and other jurists, that navigation on international rivers as well as on the open sea should be free. This doctrine was proclaimed, November, 1792, by the provisional Executive Council of France in regard to the Scheldt $(t)$, which had been closed by the Treaty of Münster, 1648. In 1814 the Treaty of Paris (Art. V.) declared the freedom of navigation on the Scheldt, and on the Rhine from the point at which it becomes navigable to the sea. The following year the Final Act of the Congress of Vienna stipulated (Art. CVIII.) that such States as are separated or traversed by the same navigable river should agree to regulate in common all matters relating to its navigation, and that a commission should be appointed for the purpose. The governing principle was laid down in Art. CIX., which said that navigation on rivers of this kind, from the point where each becomes navigable to its mouth, is to be free, subject to the observance of equitable and uniform police regulations. With a view to setting up an authority for controlling the navigation régime and for serving as a means of communication between the States of the Rhine on all matters relative thereto, it was agreed (in Annexe XVI. to the Final Act) that a central commission should be appointed, comprising delegates named by the various bordering States.

The Danube Commission.

A further step was taken by the Treaty of Paris, March 30, 1856, whereby the contracting parties (Great Britain, Austria, France, Prussia, Russia, Sardinia, and Turkey) agreed to regulate the navigation of the Danube

(r) De iure belli ac pacis, lib. ii. c. $2, \S 13,2$.

(s) Droit des gens, liv. ii. $\$ \S 104,117,123,128,129,134$.

$(t)$ This proclamation has been designated 'the first charter of contemporary fluvial liberties': E. Engelhardt, $D u$ régime conventionnel des fleuves internationaux (Paris, 1879), p. 24. 
conformably to the principle enunciated in 1815, and to set up commissions to carry out the necessary work. Several international conventions had since 1779 been arrived at in respect of the Danube ; but owing to rivalry between Russia and Austria real freedom of navigation had never been secured. 'The three mouths of the river had fallen into the possession of Russia, who was, till 1829 , sole mistress of its navigation. In 1840 a treaty between the two countries was signed, proclaiming liberty of navigation; but nothing was done to put the principle in practice. It was thus reserved for the Congress of Paris to reach a practicable solution of the problem. The fundamental provisions on the subject contained in the Treaty of Paris are as follows:-

'ART. XV. The Act of the Congress of Vienna having established the principles intended to regulate the navigation of rivers which separate or traverse different States, the contracting Powers stipulate among themselves that these principles shall in future be equally applied to the Danube and its mouths. They declare that its arrangement henceforth forms a part of the public law of Europe, and take it under their guarantee.

'The navigation of the Danube cannot be subjected to any impediment or charge not expressly provided for by the stipulations contained in the following Articles; in consequence, there shall not be levied any toll founded solely upon the fact of the navigation of the river, nor any duty upon the goods which may be on board of vessels. The regulations of police and of quarantine to be established for the safety of the States separated or traversed by that river shall be so framed as to facilitate, as much as possible, the passage of vessels. With the exception of such regulations, no obstacle whatever shall be opposed to free navigation.

ART. XVI. With a view to carry out the arrangements 
of the preceding Article, a commission in which Great Britain, Austria, France, Prussia, Russia, Sardinia, and Turkey should each be represented by one delegate, shall be charged to designate and to cause to be executed the works necessary below Isatcha, to clear the mouths of the Danube, as well as the neighbouring parts of the sea, from the sands and other impediments which obstruct them, in order to put that part of the river and the said parts of the sea in the best possible state for navigation.

In order to cover the expenses of such works, as well as of the establishments intended to secure and to facilitate the navigation at the mouths of the Danube, fixed duties, of a suitable rate, settled by the commission by a majority of votes, may be levied, on the express condition that, in this respect as in every other, the flags of all nations shall be treated on the footing of perfect equality.

Art. XVII. A commission shall be established, and shall be composed of delegates of Austria, Bavaria, the Sublime Porte, and Wiirtemberg (one for each of these Powers), to whom shall be added commissioners from the three Danubian Principalities, whose nomination shall have been approved by the Porte. This comimission, which shall be permanent, (1) shall prepare regulations of navigation and river police; (2) shall remove the impediments, of whatever nature they may be, which still prevent the application to the Danube of the arrangements of the Treaty of Vienna; (3) shall order and cause to be executed the necessary works throughout the whole course of the river; and (4) shall, after the dissolution of the European Commission, see to maintaining the mouths of the Danube and the neighbouring parts of the sea in a navigable state.

ArT. XVIII. It is understood that the European 
Commission shall have completed its task, and that the River Commission shall have finished the works described in the preceding Article, under Nos. (1) and (2), within the period of two years. The signing Powers assembled in conference having been informed of that fact, shall, after having placed it on record, pronounce the dissolution of the European Commission, and from that time the permanent River Commission shall enjoy the same powers as those with which the European Commission shall have until then been invested.

ART. XIX. In order to ensure the execution of the regulations which shall have been established by common agreement, in conformity with the principles above declared, each of the contracting Powers shall have the right to station, at all times, two light vessels at the mouths of the Danube.'

It is beyond our purpose here to discuss fully the con- Main faatures stitution, working, and achievements of the Danube commission. Commission $(u)$; it will suffice to point out the main features of this institution, which is unprecedented in international law and usage. It is a kind of European syndicate, enjoying practically full independence and exercising many functions attaching to sovereignty. Indeed, it possesses the status of international personality, and in many respects is in the position of an autonomous State. It is not amenable to the jurisdiction of the Government in whose territory it is situated (viz. Roumania). It is empowered to negotiate, without any intermediary, with neighbouring States. It has an exchequer, to which those who benefit by its services contribute; and it publishes a budget in every State that it represents. It possesses a flotilla, which flies its own

(u) Seө G. Demorgny, La question du Danube (Paris, 1911); E. Engelhardt, in Revue de droit international (Bruxelles), vol. xvi. (1884), pp. 360 seq. 
distinctive flag. It may contract loans, and dispose of land. It is both a deliberative and an executive body. As a deliberative body, it has the power to examine any matter whatever relating to the navigation on the Danube ; it lays down police regulations, shipping rules, tariff scales, plans of necessary works, \&c.; and resolutions carried by a majority of the votes become law. As an executive body it puts its own decisions into effect; and for this purpose it employs a staff of specialists. It punishes contraventions of its laws and regulations, and, in its capacity of supreme tribunal, it reviews the judgments pronounced by the Navigation Inspector or the Superintendent of the Port of Sulina, who are judges of first instance. Its legislative, executive, and judicial decisions are supported by the light vessels of the Powers stationed at the mouth of the Danube, which secure compliance therewith by the ships of their respective nationality.

Other provisions regulating the Danube.
In 1865 the works and establishments of the Commission were declared to be neutralised, so as to be immune from attack in case of war. In 1866, at a conference in Paris, the European Commission was extended for five years. The Treaty of London, 1871, modified certain stipulations of the Treaty of Paris, 1856, so as to allow Russia to maintain a fleet in the Black Sea; but to counterbalance this modification, the neutrality of the European Commission was protected by additional guarantees. Its powers were also extended for twelve years. In the Russo-Turkish War, 1877, complaints were made against the belligerents, because their operations interfered with the free navigation of the Danube; but in the discussion that followed it appears to have been recognised that the international transactions relating to the river did not invest it entirely with a neutral character, and that they simply required belligerents to 
respect the works and establishment of the Commission, to impede the navigation as little as possible, and restore it, in case of interference, as speedily as possible. However, by the Treaty of Berlin, 1878, all fortresses between the Iron Gates and the sea were to be demolished, and new ones were forbidden to be constructed; and within the same limits no warships, other than light vessels used for police and customs purposes, were to navigate the river. Roumania, having been declared independent, was to be represented on the Commission, whose sphere of operations was extended to Galatz. By subsequent treaties (e.g. in 1883 and 1904) the authority of the Commission was renewed and enlarged; that of 1904 provided for its prolongation for successive periods of three years, but reserved to each of the eight States represented the right to dissolve it by denouncing it a year before the termination of a triennial period.

Finally, as to Constantinople. The best solution in Future of the circumstances is without doubt to constitute it a free nople. town, and place it under the conjoint protection of the Powers, including the United States. Constantinople is so closely connected with the Straits, that the establishnent of a new régime for the latter imperatively demands the establishment of a new régime for the former. There is no need to dwell on the commanding position of the town and on its supreme importance, economic as well as strategic. To place it in the hands of any great State is to give that State the power to acquire predominance in Asia Minor and to control the important route viâ Suez and the Persian Gulf to the Far East. To allow the town to remain in the hands of the Turks is to invite a repetition of the European tragi-comedy of diplomatic intrigues, underhand arrangements, international combinations and counter-combinations, with their inevitable results-rivalries, disputes, and wars. 
Position of Turkey with regard to Europe.

Turkey has been found grievously wanting. Her presence in Europe has not proved a benefit either to herself or to anyone else. What with her misgovernment, her maladministration, her downright incompetence in all matters of polity, her aversion from European civilisation, it would be in the general interest that she should cease to be a European Power occupying such an important position between the East and the West. Between the European and the Mussulman conceptions of law and government there is an irreconcilable antagonism $(x)$. Islam is stationary and opposed to progress; its idea of a State is a warlike theocracy, a religious feudalism. As M. Paul Deschanel aptly said, in a speech delivered in the Chambre des Députés, February 29, 1888: 'L'Orient est le pays de la tradition par excellence; il a gardé à travers les siècles son caractère indélébile; et l'un des traits essentiels de ce caractère, c'est le mélange, la confusion des choses religieuses avec les affaires civiles. C'est ce qui explique les difficultés insurmontables auxquelles se sont heurtés tous les réformateurs ottomans, et c'est ce qui explique aussi les erreurs, les mécomptes des politiciens occidentaux, pourtant fort avisés, mais qui demandaient à l'Empire turc des mesures, des réformes incompatibles, je ne dis pas seulement avec son organisation, mais avec son existence même, parce qu'ils paraissaient croire qu'ils avaient affaire ’̀ un État politique comme le nôtre, tandis qu'en réalité ils se trouvaient en présence d'une théocratie guerrière, d'une féodalité religieuse, d'une orthodoxie immuable' $(y)$. The Turks have never forgotten that they were conquerors. Between them and the conquered there have always been animosity, friction, and misunderstanding; abuses and persecutions

(x) Cr. M. Choublier, La question d'Orient depuis le traité de Berlin (Paris, 1897), pp. 495-503.

(y) Journal Officiel, March 1, 1888. 
have been engendered interminably; massacres have been numerous; a reign of force has prevailed. The Ottoman Empire is a heterogeneous structure; it is not a nation at all. Guizot long ago warned the world that there is nothing to hope for from the Mussulmans in Europe (z). Subsequent events have abundantly confirmed his conclusion.

Whether or not Turkey is to remain in Europe as an independent State we need not discuss.' But one thing is certain-she has failed completely in her guardianship of the Straits, and she has betrayed the trust placed in her by solemn international engagements; so she must withdraw from Constantinople and the Straits territory and leave both to Europe to be made free and to be internationalised.

(z) Mémoires, vol. vii. p. 240. 



\section{( 261$)$}

\section{N D E X.}

ABD-UL-AzIz, 131.

Aberdeen, Lord, 82, 85.

Adrianople, Treaty of (1829); 50-53.

Aehrenthal, 189.

Akkerman, Treaty of (1826), 49, 50.

ALABAMA affair, 112.

Albanta, 239.

Alexander I., policy of, 34 .

Alexander II., 132.

policy of, 102.

Alexeieff, Professor, on the Straits, 200.

Alexinskr, M., view as to Constantinople and the Straits, $210,211$.

Alr, Pasha of Janina, 48.

Ali Pasha, 109.

Amiens, Peace of (1802), 34.

'Ancient ruli of the Ottoman Empire,' 43, 75, 77, 90, 22.

Andrassi, 131, 146.

Anne, Tsarina, 21, 24.

Athens, Treaty of (1913), 194.

Austria,

annexation of Bosnia-Herzegovina, 189.

capitulations obtained by, 20.

Austrian Succession, war of, 26.

Azof, Sea of, 228. 
Batkoff, Professor, view as to Constantinople, 201.

Balkan league, plan for forming, 190.

Russian views as to (1912), 192.

Balkan Rising (1875), 131.

Balkan War, First, warships of Powers pass Straits in, 174.

Balkan Wars, 193, 194.

Baltid Sea, mare liberum, as a, 12, 13.

Barbolani, 126.

Batoum, 89, 155, 156, 158, 159.

Beaconsfield, 155.

Belarade, Treaty of (1739), 25.

BeLts, the, position of, 14.

Benedetti, 85.

BerLiN,

Congress of (1878), 148.

memorandum (1876), 131.

Treaty of (1878), 149, 247.

Bernstorff, 127.

Beust, 108, 112, 120.

Bismarck, 112, 113, 115, 147, 148, 156.

denunciation of Treaty of Paris, on, 105.

experiences of Russia, on the, 8 .

Triple Alliance, and the, 130.

Black Sea,

' chaste and pure virgin,' as a, 4, 22.

commerce in, $227-229$.

navigation in, under earlier capitulations, 20, 21.

neutralisation of, 96, 99, 101.

Russian fleet in, 90 seq.

Russian lake, as a, 201.

Turkish lake, as a, 17, 18, 20.

various Powers concerned as to, 231-233.

Bosnia-Herzegovina, annexation of, 189, 190. 


\section{Bosphorus and Dardanelles,}

closing of, in recent wars, 194.

commerce in, 232, 233.

convention as to. See Straits Convention.

exclusive possession of, and international law, 230 .

freedom of passage to all vessels, 202, 233-237.

International Commission suggested, 241.

internationalisation suggested, 206, 207, 210-212, 219 ,

$236 \mathrm{seq}$.

passage of warships, instances of, 37, $150 \mathrm{seq} ., 163 \mathrm{seq}$.

principles suggested for, $239 \mathrm{seq}$.

problem of, 1 seq., $227 \mathrm{seq}$.

conflicting claims, 2.

essence of, 3, 4.

present character of, $227 \mathrm{seq}$.

present war, and the, 1 .

remains to be solved, 8,9 .

régime of, why failed, 225.

regulations of the Porte as to, 81, 82 .

rule of, evolution of, $17 \mathrm{seq}$.

Russian possession, as a, advocated, $203 \mathrm{seq}$.

whether advisable, $229 \mathrm{seq}$.

Russian views as to, 194 seq.

solutions suggested, 224 .

treaties as to. See names of treaties.

Bourqueney, 87, 93, 151.

BouteniefF, 69.

BRESLAU, the, 174, 209, 225.

Broglie, Duc de, 127.

Brunnow, 73, 81, 102, 107, 109, 110, 111, 120, 122, 125, 126, 127.

Brussels Conference, 1890, 237.

Budhanan, 109.

Bucharest,

Convention of (1877), 136.

Treaty of (1812), 45.

Budberg, 40.

Bulgaria, gunboat passes Straits (1898), 167.

independence proclaimed (1908), 189. 
'Bulgarian Atrocities,' 131.

Buol, 87, 90, 91, 93.

ByNkershoek, territorial sea, on, 11.

Canals, interoceanic, status of, $15,16$.

Campo-Formio, Treaty of (1797), 32.

Capitulations, instances of, 18-20. system of, 18.

Cartowitz, Treaty of (1699), 22.

Caspian Sea, status of, 12.

Catherine II., policy of, 5, $26 \mathrm{seq}$.

Caulaincourt, 41.

Chardes VI., 23.

Charles IX., commercial treaty with Turkey, 19.

Chaudordy, 111, 112.

Clarendon, 111, 127.

Clémenceau, 234.

Congo, the, 237.

Congo Free State, 237.

Constantinople,

Belgian rule suggested, 215.

capture of, by Turks, 17 .

free town, as a, views as to, $182,200$.

German influence at, 192.

internationalisation suggested, $215 \mathrm{seq} ., 219 \mathrm{seq} ., 247$.

Russian possession, as a, views in favour of, 184, 186, $187,194,195,213-215$.

whether advisable, 229-231.

Russian views as to, $194 \mathrm{seq}$.

solutions suggested, 224.

Treaty of (1784), 29.

(1798), 32,35 .

(1805), 36,37 .

(1809), 43-45, 66, 68, 90.

(1913), 194.

Triple Entente, suggestion for placing under, 200. 
Constanza, Nicholas II. and King Carol meet at, 194.

Copenhagen, Treaty of (1857), 13, 14.

Cowley, Lord, 151.

Crimean War, peace negotiations in, $87 \mathrm{seq}$.

Straits Convention and the, 87.

Danilewsiry, 183 seq.

Danube,

navigation of, 94, $242 \mathrm{seq}$.

River Commission, establishment of, 94, 245-247.

Dandbian Principalities,

occupation of (1853), 85, 86.

organisation of, 94 .

Dardanelles, the. See Bosphorus and Dardanelles.

Peace of the (1809), 43-45, 68.

Demmark, capitulations obtained by, 20 .

DerBY, Lord, 134, 135, 137, 141, 145.

Deschanel, 248.

Dournovo, view on the Straits Question, 200.

Drouyn de LhuYs, 92.

Duckworth, Admiral, 40.

EAsT, rivalry between England and Russia in the, 70 .

ELIZABETH, capitulation obtained by, 19.

ERfurr, Treaty of (1808), 43.

European Politios, governing factor of, 2. See also Bosphorus and Dardanelles.

FisH, Hamilton, 112.

'Four Points,' the, 87.

Fravers I., capitulation obtained by, 18.

Francis Joseph, 88.

Franco-Prugsian War, 103. 
Gibraltar, Straits of, 15.

Gladstone, 127.

GOEBEN, the, 174, 209, 225.

Goremykin, M., view as to the Straits, 204.

GortchaкоFF, 88, 90, 133, 139, 142, 143, 148, 156, 189, 234. circular of, denouncing Treaty of Paris, 105 seq.

Granville, 107, 109, 120, 122, 125, 126, 160.

Great War (1914), effect on Russian opinion as to the Straits, 199 seq. Straits question in, 174.

GreECr, attempt to secure passage of warship through Straits, $166,167$.

Greer Empire, re-establishment proposed, 29, 48, 199.

Greer Revolt (1821), 48.

Greek War of Independence, 53.

Grotius, international rivers, on, 242. territorial sea, on, 11.

Guizot, 249.

Gulrstan, Treaty of (1813), 12.

Hague Conference (1907), 175.

Hanotaux, M., view as to free passage to all vessels in the Straits, 219.

Hay-Pauncefote Treaty, $239 \mathrm{n}$.

Henry III. of France, commercial treaty with Turkey, 19.

Henry IV., commercial treaty with Turkey, 19.

Hetairia Philike, 48.

Hrgh SeA, international law, under, 10.

Holy Alliance (1815), 47.

Holy Places, question of the, 83.

Hypsilanti, Prince, 48. 
Ibrahim PAsha, 65.

IaNaTrafF, 104, 132. view on Turkish question, 181, 182.

Intand Sea, international law, under, 11, 12.

INLETs, international law, under, 11.

INTERNational Co-operation, 237-239.

INTERNATIONAL UnIONS, 237-238.

InternationaLisation,

Bosphorus and Dardanelles, of, suggested, 206, 207, 210-212, 219, $236 \mathrm{seq}$.

Constantinople, of, suggested, 215 seq., 219 seq. neutralisation distinguished from, 239.

INTERVENTION IN TURKeY (1839), 72, 73 ; (1877), 136.

IsvolsKr, M., 189.

ITALINSKY, $35,37,39$.

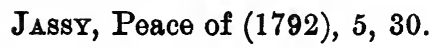

JosEPH II., 29.

Kamarowski, on Constantinople and the Straits, 198, 199.

KexserLing, 105.

KIUTA YEH, Convention of (1833), 57, 62, 72.

KNIAZ POTEMKIN, incident of (1905), 173.

Kотснотвеу, report as to Turkey, 34.

Kothiarietskr, Professor, on the Straits, 201.

Kovaletskry, M., on Russian possession of the Straits, 205.

KutchuK-KAINARDJI, Treaty of (1774), 5, 27, 28.

LAKEs, international law, under, 11, 12.

League of Nations, 237.

Light Vrasels, increase of, in the Golden Horn, 163. passage through the Straits, 76, 97.

P. 
LobaNoff-Rostovsky, 152, 164.

Loftus, interview with the Tsar, 132.

LoNDon,

Conference of (1871), $121 \mathrm{seq}$.

Declaration of (1871), 119, 121, 137.

Treaty of (1827), 49. (1840), $74-77$.

- (1841), 78, 79, 80, 81, 89, 234.

(1871), 127-129, 164, 234, 246.

difficulties raised by, 154 .

(1913), 193.

Lours XIV., capitulation obtain $ə d$ by, 19.

Louis XV., capitulation obtained by, 20, 25.

Lroff, Prince, against territorial acquisition by Russia, 212 .

Macedonid, zones of inspection in, 238.

Magellan, Straits of, 14.

MALACOA, the, 171 .

Manteuffel, 103, 108.

Marschall von Bieberstein, 191.

Martens, 235.

Menemet Ali, revolt of, $54 \mathrm{seq}$.

Menshikoff, 84, 85.

Metternich, 71, 72, 73, 90.

Mitutary necessity, 116.

Miliukoff, M., on Constantinople and the Straits, 195, 205, 211, 212.

MoLtKe, 116.

Montebello, 167.

Montenearo, war on Turkey (1876), 131.

MÜNCHENaRätz, Convention of (1833), 71, 72.

Münster, Treaty of, 242. 
MuraviefF, 55, 56.

Musurdos Pasha, 123, 124, 126, 136.

Napoleon,

military successes of, 37.

partition question discussed by, 41 .

possession of the Straits, on the, 231.

projected coalition against, 35 .

Napoleon, President of the French Republic, 83.

Nafarino, 50.

Near Eastern Question, solution necessary, 1.

Nesselrode, 54, 60, 82, 89.

Netherlands, capitulations obtained by, 19 .

Neutralisation,

Black Sea, of, 96, 99.

internationalisation distinguished from, 239.

Nicholas I., 49, 50 seq., 82, 83, 84.

Nicholas, Grand Duke, 145.

NIGER, the, 237.

Novicoff, 108.

O'Connor, 168.

OrounefF, 108.

ORLOFF, 57, 59, 60.

OUBRIL, 108.

OUstinoff, 151.

Palmerston, 68, 70, 73, 74, 85, 90, 107, 127, 234.

Panama Canax, status of, 16, $239 \mathrm{n}$.

Paristamism, 131.

Panslat movement, $130,131,183-187$.

$17(2)$ 
Paris,

Convention of (April 15, 1856), 98.

Treaty of (1814), 242.

(March 30, 1856), 94-97, 237, 242, 246.

denunciation of, $101 \mathrm{seq}$.

Passarowitz, Peace of (1718), 23.

PaUl I., policy of, 5, 32.

Pauncefote, Lord, 239.

Pears, Sir E., view as to Constantinople and the Straits, 222, 223.

Persian War (1722-3), 5, 23, 24.

Peter the Great, conquests of, 5, 21, 22.

Peteraurg, the, 170, 171, 172.

Pobiedonostseff, 184.

Polish Succession War, 24.

Political expedienoy, 1.

Ponsonby, 60, 61.

Pressburg, Treaty of (1805), 37, 39.

Prussia, capitulations obtained by, 20 .

Pruth, Peace of the (1711), 5, 23.

Quadruple Alitance (1815), 47.

'Reasons of State,' 1.

REAY, 175.

REBUS SIO STANTIBUS, 115, 116.

Reichenbach, Convention of (1790), 30 .

Reichstadt, meeting of Emperors at (1876), 132, 188.

Reuss, 109.

RIvers, international, navigation on, 242.

Rosen, Baron, on Russian policy, 195-198. 
Rostopchin, scheme to partition Turkey, 33.

Roussin, 59, 60.

RUMtantsEFF, 41, 42.

Russelu, Lord, 84, 92, 107.

Russia, attitude towards the Straits during nineteenth century, 178 seq.

See also Bosphorus and Dardanelles ; Constantinople. capitulations obtained by, 20 .

difficulties of, after Treaty of Paris (1856), 101. expansion of, 4.

policy of, 21.

southern outlets, with regard to, $5-8$.

position of, 21.

recent efforts to procure passage of her warships, $188 \mathrm{seq}$. recent opinion in, as to Constantinople and the Straits, 194 seq.

revolution, effect on views as to Constantinople and the Straits, 211, 212, 213.

troops sent through Straits (1897), 167.

warship refused passage through Straits (1863), 152, 153. warships pass Straits (1902), 167-169.

RUsso-JAPANeSE War, the Straits Question in, 170-172.

Safvet Pasha, 135, 136.

SAINT-Priest, 29.

SALisbury, Lord, 146, 147, 148, 156. declaration at Berlin, 156, 161, 162, 170. explanation of his declaration (1885), 159, 160.

Sav Stefano, Treaty of (1878), 146, 147.

SARDINIA, warship refused passage through Straits (1862), 152.

SAZoNofr, M., 192. view as to Russian access to open sea, 205.

ScHELDT, the, 242.

SeA,

high, under international law, 10.

land-locked, under international law, 11, 12. territorial, under international law, 10, 11. 
Sébastiant, 37, 39, 40.

SERBIA, war on Turkey (1876), 131.

SEYMour, Sir Hamilton, 83, 84.

Shovaloff, 134, 139, 141, 143, 145, 147.

declaration at Berlin, 157, 170.

Srorlies, Two, capitulations obtained by, 20.

Sistova, Peace of (1791), 30.

Skodra, expedition to, 239.

Slat federation, suggested establishment of, 185 .

SLobodsia, armistice of (1807), 41.

SMOLENSK, the, 170, 171, 172.

Sound, the, position of, 14 .

SpaIN, capitulations obtained by, 20.

StaAe, 109.

Stanley, 111.

StraIts, international law, under, $13-15$.

Straits Convention (1841), 78, 79, 80, 81.

Crimean War and the, 87.

Nesselrode's view of, 89.

Straits Convention (1856), 97, 98.

Austria, attitude of (1911), 191.

collective character of, $98,153,154,156 \mathrm{seq}$.

France, attitude of (1911), 191.

Germany, attitude of (1911), 191.

Great Britain, altered views as to (1902), 169. attitude of (1911), 191.

interpretation and application of, $150 \mathrm{seq}$.

interpretation at Berlin Congress, 155.

Russian interpretation (1895), 162, 163.

Russian views altered as to (1902), 169.

Turkey, determination to maintain (1911), 192.

violation by Turkey (1914), 174, 175.

Stratford DE Redcliffe, 85.

Stratheden ard Campbell, Lord, 159.

SUez Canal, status of, 15.

SWEDEN, capitulations obtained by, 20. 
TOHARIKoff, 190.

TerReLL, 165.

Tefrik Pasha, 166.

THILE, 108, 109.

Thugut, 28.

Tilsit, Peace of (1807), 40.

Tourkmantchai, Treaty of (1828), 12.

Toynbee, view as to Constantinople and the Straits, 220--222.

Treaties. See name of particular treaty. abrogation of, grounds for, 118 .

binding force of, 117, 118, 121, 122.

Triple Alliance, 130.

Trodbetzkor, Prince, view as to Constantinople and the Straits, 208-210.

TURCo-Italian War (1912),

Dardanelles in, 173.

Russia's step to secure passage of her warships through Straits, 190.

TURKEY,

conditions in, $2,3$.

intervention in (1839), 72, 73; (1877), 136.

invasion of (1877), 136, 137.

mediation of Powers requested (1877), 137.

partition schemes (1800), 33 ; (1807), 41 ; (1853), 83, 84. position of, Europe, in relation to, 2, 3, 248.

public law of Europe, in regard to, 47, 94.

'sick man,' as a, 82, 178, 180, 200.

war with Italy. See Turco-Italian War.

war with Russia (1877-8), 136 seq.

Tuscany, capitulations obtained by, 20.

\section{United States,}

efforts to procure passage for warships in the Straits, $216-218$.

military guardianship of the Straits, suggestion as to, $220-222,236$. treaty with Turkey (1830), 54. warship passes Straits (1868), 153. warship refused passage through Straits (1858), 151; (1895), 165. 
Unkiar-Skelessi, Treaty of (1833), $62 \mathrm{seq}$. declaration of Russia as to, 73, 74 . protests against, $67-69$.

UxKÜLL, 108.

VATTEL, 242.

Veraennes, 26.

Vienna,

Congress of (1815), 47, 237, 242.

Treaty of (1735), 24.

Villeneuve, 25.

Visconti-Venosta, 108.

WARSHIPS, passage through Bosphorus and Dardanelles. See Bosphorus and Dardanelles. what vessels are, $175,176$.

Waterways, position undarinternational law, $10 \mathrm{seq}$.

West African Congress, 237.

WestMoreland, Lord, 87, 93.

William I., 103, 107.

'Young Turkey' Party, 131. 

$n^{\prime}$

1 


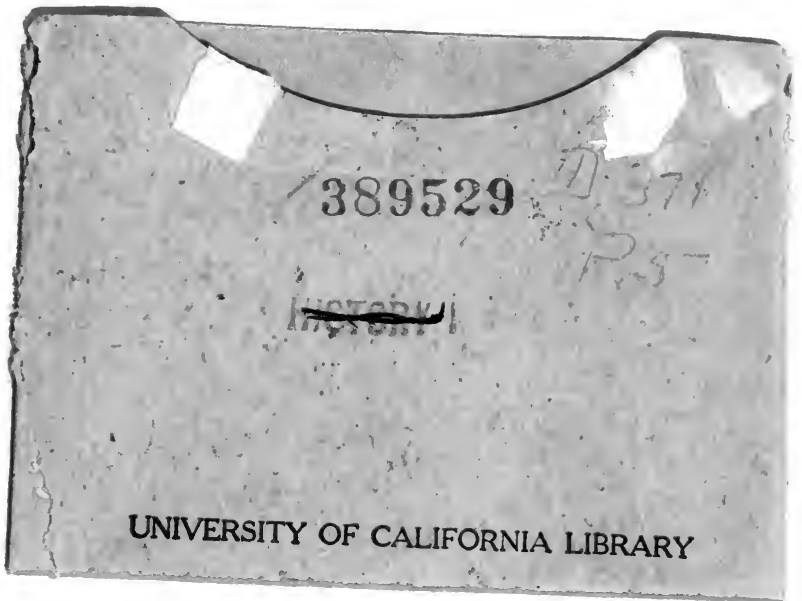


$\cdot \%$ 